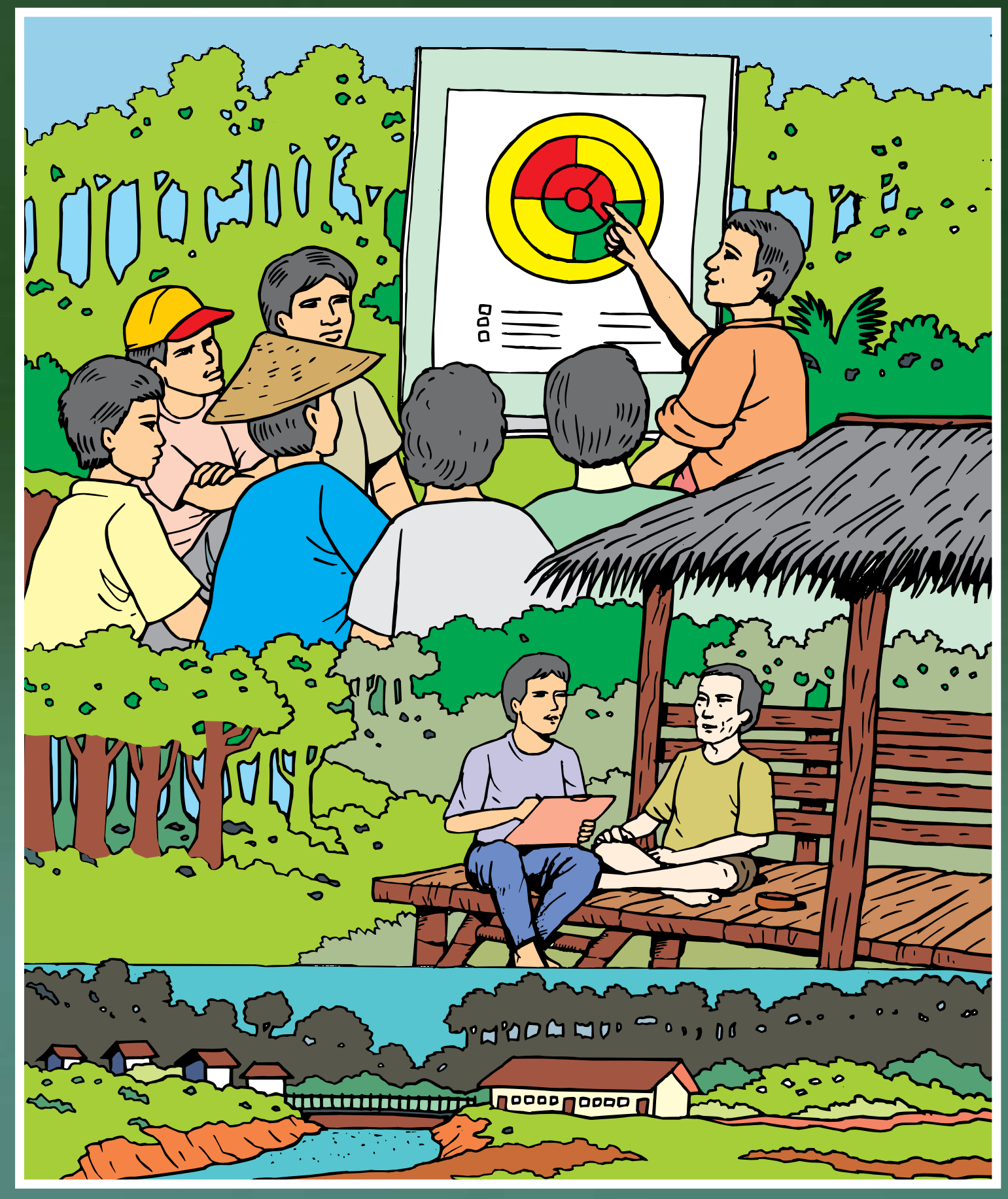

Mengkaji Kemiskinan dan Kesejahteraan Rumah Tangga

\author{
Sebuah Panduan \\ dengan Contoh \\ dari Kutai Barat, Indonesia
}

Ade Cahyat Christian Gönner Michaela Haug 


\section{Mengkaji Kemiskinan dan Kesejahteraan Rumah Tangga \\ Sebuah Panduan dengan Contoh dari Kutai Barat, Indonesia}

Ade Cahyat, Christian Gönner, dan Michaela Haug 
(c) Hak Cipta 2007 CIFOR.

Seluruh hak dilindungi undang-undang. Dilarang memperbanyak, menyimpan dalam sistem penyimpan data, atau menyebarkan bagian mana pun dari dokumen ini dalam bentuk atau alat apa pun (elektronik, mekanis, fotokopi, rekaman atau lainnya), tanpa izin sebelumnya dari penerbit. Diharuskan mengutip dengan benar:

Cahyat, A., Gönner, C. and Haug, M. 2007 Mengkaji Kemiskinan dan Kesejahteraan Rumah Tangga: Sebuah Panduan dengan Contoh dari Kutai Barat, Indonesia. CIFOR, Bogor, Indonesia. 121p.

ISBN: $978-979-1412-28-5$

Sistem pemantauan kemiskinan yang diuraikan dalam panduan ini dikembangkan oleh Tim Penyusun bersama dengan Tim Pemantau dari Pemerintah Kabupaten Kutai Barat. Model kemiskinan yang digunakan sebagai dasar diciptakan oleh seluruh tim proyek (Proyek Kemiskinan \& Desentralisasi CIFOR-BMZ).

Gambar dan bagan oleh Michaela Haug, Timbul, Christian Gönner, dan Ade Cahyat.

Diterbitkan oleh:

Center for International Forestry Research

J. CIFOR, Situ Gede, Sindang Barang

Bogor Barat 16115, Indonesia

Tel.: +62 (251) 622622; Fax: +62 (251) 622100

E-mail: cifor@cgiar.org

Website: http://www.cifor.cgiar.org 


\section{Daftar Isi}

Singkatan dan Akronim

Kata Pengantar

Ucapan Terima Kasih

Konsep Pemantauan

Modul 1. Pengembangan Indikator Kemiskinan Lokal

Modul 2. Perekrutan Pendata Desa

Modul 3. Pemilihan Responden

Modul 4. Teknik Wawancara

Modul 5. Indikator dan Lembar Wawancara

Modul 6. Pemeriksaan Hasil Wawancara

Modul 7. Memasukkan Data ke dalam SPSS

Modul 8. Penghitungan Indeks

Modul 9. Penyajian Indeks

Modul 10. Pemeriksaan Lapangan 
Lampiran

Lampiran 1. Kuisioner Pemantauan Resmi

Lampiran 2. Pengelompokan Indikator dan Klasifikasi Nilai

Lampiran 3. Kode Desa dan Kecamatan

File berikut ini dapat di-download dari http://www.cifor.cgiar.org/manual:

Download 1. Rumahtangga.sav

Download 2. Indeksrumahtangga.sav

Download 3. Indeksrumahtanggafinal.sav

Download 4. petakemiskinan.zip 


\section{Singkatan dan Akronim}

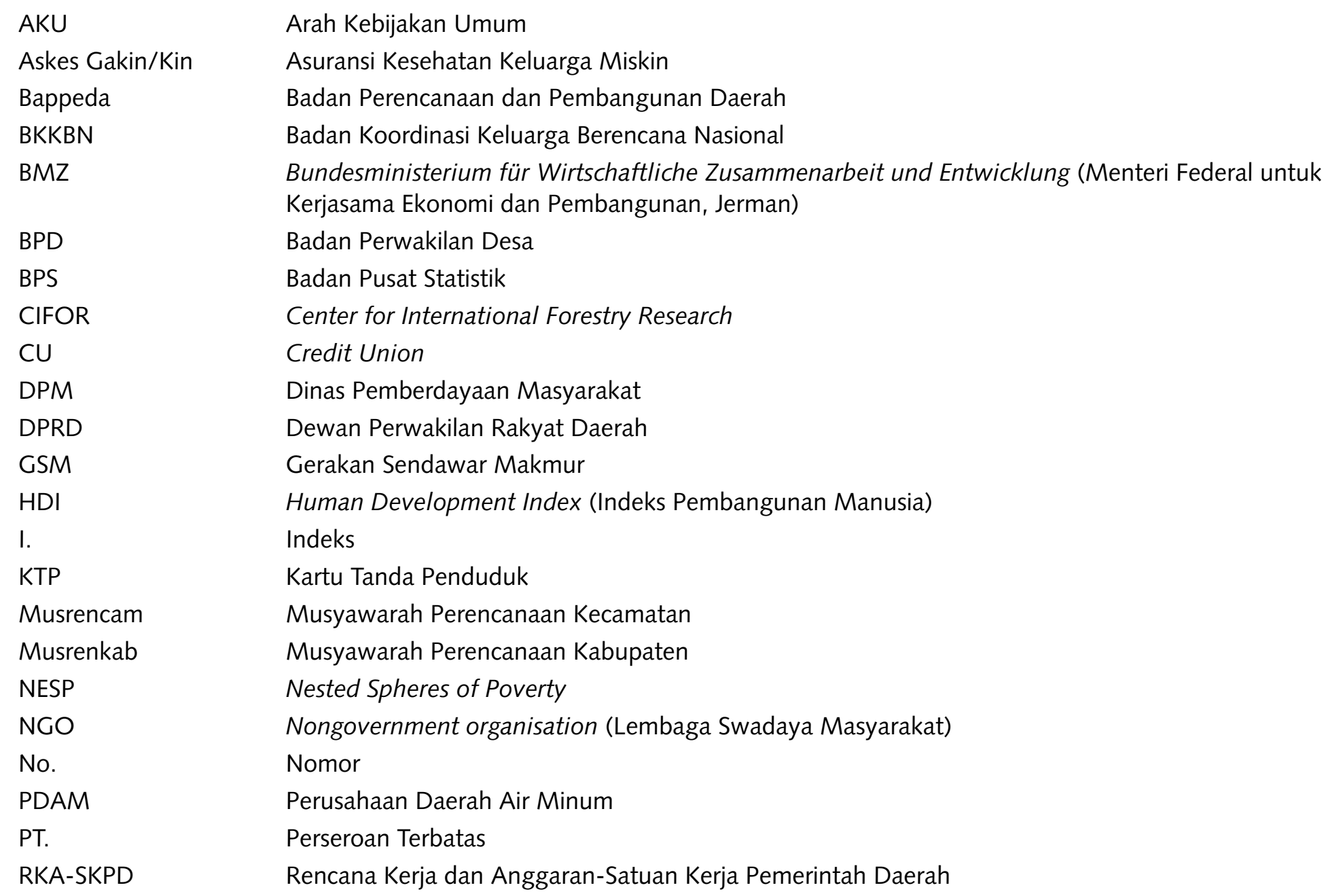




$\begin{array}{ll}\text { Raskin } & \text { Beras bagi Masyarakat Miskin } \\ \text { Rp. } & \text { Rupiah } \\ \text { Rsp } & \text { responden } \\ \text { SD } & \text { Sekolah Dasar } \\ \text { SLTA } & \text { Sekolah Lanjutan Tingkat Atas } \\ \text { SLTP } & \text { Sekolah Lanjutan Tingkat Pertama } \\ \text { SPP } & \text { Surat Perintah Pembayaran } \\ \text { SR } & \text { Sekolah Rakyat } \\ \text { SSB } & \text { Single Side Band (radio) } \\ \text { Std-dev } & \text { simpangan baku } \\ \text { SWB } & \text { subjective wellbeing (kesejahteraan subjektif) } \\ \text { TUPOKSI } & \text { Tugas Pokok dan Fungsi } \\ \text { UKM } & \text { Usaha Kecil dan Menengah } \\ \text { UNDP } & \text { United Nations Development Programme (Program Pembangunan PBB) } \\ \text { V } & \text { Variabel } \\ \text { Var } & \text { Variabel }\end{array}$




\section{Kata Pengantar}

Panduan pemantauan kemiskinan ini dikembangkan oleh Tim Pemantau Kemiskinan Pemerintah Kabupaten Kutai Barat dan proyek "Menjadikan pemerintah daerah lebih tanggap terhadap kemiskinan: Pengembangan indikator dan alat untuk mendukung pengembangan penghidupan yang berkelanjutan dalam desentralisasi" yang disingkat menjadi: "Kemiskinan dan Desentralisasi: CIFOR-BMZ". Panduan ini mencerminkan hasil proses pembelajaran partisipatif selama tiga tahun yang terdiri dari berbagai pertemuan, lokakarya, studi kasus desa, survei baseline atas 20 kampung miskin (desa-desa di Kutai Barat disebut kampung), dua kali uji coba pemantauan di 20 kampung lain, dan survei pemantauan menyeluruh atas 223 kampung di Kutai Barat.

Tujuan utama panduan ini adalah menyediakan petunjuk teknis dan informasi latar belakang bagi para pemantau kemiskinan di daerah. Oleh karena itu, panduan ini disusun dalam bentuk modul-modul sesuai dengan proses kerja pemantauan. Panduan ini menguraikan sistem pemantauan kemiskinan secara rinci, mulai dari pengembangan indikator kemiskinan lokal sampai dengan analisis akhir dan penerapan data pemantauan.

Mungkin ada yang mempertanyakan perlunya pemantauan kemiskinan lokal ini, karena Pemerintah Indonesia juga telah melakukan pengukuran kemiskinan melalui sebuah sistem terpusat yang dilakukan oleh Badan Pusat Statistik (BPS). Reformasi desentralisasi memberikan sumber daya dan tanggung jawab yang lebih banyak bagi pemerintah daerah untuk pembangunan dan penanggulangan kemiskinan. Oleh karenanya, pemerintah daerah perlu mengidentifikasi masalah dan prioritas daerahnya masing-masing agar sumber daya itu dapat dimanfaatkan sebaik-baiknya. Mengingat sistem pendataan kemiskinan dari pemerintah pusat mungkin tidak dapat membantu dalam penentuan prioritas pembangunan, pemeritah daerah perlu mengumpulkan informasi untuk keperluan perencanaannya sendiri. Pendekatan pemantauan kemiskinan yang diuraikan dalam panduan ini adalah contoh dari proses yang didorong oleh kebutuhan tersebut.

Meskipun indikator yang digunakan dalam pendekatan ini dipilih berdasarkan prioritas lokal, banyak di antaranya dapat diaplikasikan dalam konteks yang lebih luas. Oleh karena itu, panduan ini dapat juga digunakan sebagai contoh praktis oleh pemerintah daerah setempat yang ingin mengembangkan pemantauan kemiskinan di daerahnya sendiri atau oleh pihak mediator, seperti LSM dan proyek-proyek pembangunan lainnya. 


\section{Ucapan Terima Kasih}

Panduan ini tersusun berkat kerja sama antara Pemerintah Kabupaten Kutai Barat, Proyek Kemiskinan dan Desentralisasi CIFOR-BMZ dan sejumlah individu yang penuh antusiasme dari Kabupaten Kutai Barat. Secara khusus, kami mengucapkan terima kasih kepada Rama A. Asia, Encik Mugnidin, Silas Sinan, Fredrick Ellia, Yuvinus Nyintih, Fincen Allotodang dan Asrani dari Pemkab Kutai Barat; Subhan Noor, Sangga Sarira, Firdaus, Abimael, Elivianus, Edi Almudin, Erwin Dani, Eli Surario, Rudi Warjono dan Jakaria dari Tim Pemantau; tim survei baseline (2003), yang terdiri dari Darius Dalip, Kukuh Tugiyono, Doni Tiaka, Brigita Edna, Maria Goretti Dau, Berry Iranon, Harifuddin, Muksin, Supiansyah dan Yohanes; para pendata pada uji coba pertama (2004), yang terdiri dari Erwin Dani, Mikael Meksis, Yosep Darius, Wehang, dan Benyamin; para pendata pada uji coba kedua (2005), yang terdiri dari Y. Njuk Hanyeq, Mikael Deng, David Erison, Rusandi, Mikael Muis, Y. Silam Ajang, Arlis, Markus, Hang Huvang dan Junaidi; tim pelatih, yang terdiri dari Wilhelmus, Yansen Toding Datu, Tusin, Arminsyah Sumardi, Ham Wilhelmus, Ruth Aktalia, Priyana, Rustam, dan Imanuel; tim entry data, yang terdiri dari Istanto, Gung Usat, Ami Paramban, Nanda Pratama, Rikardo, Ahmad, Yosep Suparno, Yance, Edy, Victor Yosafat, Nuryani, dan Waina; serta lebih dari 200 orang pendata desa pada pemantauan resmi (2006). Brigita Edna, Cathrin Bullinger, Bison, dan Benyamin membantu dalam proyek ini pada beberapa studi kasus.

Di CIFOR kami mengucapkan terima kasih kepada Dina Hubudin, Charlotte Soeria, Gideon Suharyanto, dan Doris Capistrano. Kami juga berterima kasih kepada editor konsultan Guy Manners. Di BMZ/BEAF Stefan Krall, Michael Bosch, dan Iris Schubert, yang telah mendukung dan mengawasi proyek ini.

Proyek GTZ ProBangkit, yang terdiri dari Roto Priyono, dan Pimpinan Tim Proyek Manfred Poppe, yang mendukung proyek ini melalui kerja samanya yang sangat baik, khususnya selama tahap akhir penyiapan panduan. Tak lupa ucapan terima kasih kami untuk Lini Wollenberg dan Godwin Limberg dari proyek CIFOR-BMZ yang telah mengkaji ulang draf awal panduan ini.

Bundesministerium für Wirtschaftliche Zusammenarbeit und Entwicklung (BMZ), Jerman yang menyediakan dana untuk penelitian dan pengembangan publikasi ini. 
Konsep Pemantauan 


\section{Konsep Pemantauan}

\section{Pengertian Kemiskinan}

Pemerintah Indonesia memiliki beberapa model kesejahteraan dan kemiskinan; misalnya, Badan pusat statistik yang mengukur kemiskinan dengan fokus konsumsi dan Badan Koordinasi Keluarga Berencana Nasional (BKKBN) yang berfokus pada kesejahteraan keluarga. Lembaga-lembaga internasional, seperti United Nations Development Programme (UNDP) juga memperhatikan isu pengembangan manusia, yang didefinisikan sebagai harapan hidup, tingkat melek huruf, pendidikan, dan tingkat daya beli per kapita. Konsep-konsep tersebut memiliki kelebihan dan kekurangan masing-masing. Dilihat dari sudut pandang pemerintah daerah, misalnya Kutai Barat, model-model tersebut memiliki beberapa kelemahan, yaitu:

- Tidak menggambarkan ciri khas lokal (misalnya, kondisi perumahan atau preferensi makanan setempat).

- Tidak menyentuh konteks kemiskinan (misalnya, tidak ada dari model tersebut yang berhubungan dengan sumberdaya alam atau konteks sosial).

- Data yang ada sering kontradiktif.

- Tidak terkait dengan pengurangan kemiskinan atau perencanaan pembangunan.

Oleh karena itu, konsep kemiskinan dan kesejahteraan yang baru diperlukan untuk menghubungkan aktivitas pemantauan dan perencanaan secara lebih baik. Ciri khas lokal, kepentingan pemerintah daerah, dan persepsi masyarakat tentang kemiskinan dan kesejahteraan dipelajari melalui studi kehidupan masyarakat secara mendalam, lokakarya pemerintah, dan analisis kebijakan. Berdasarkan temuan dari pembelajaran partisipatif ini, kemiskinan didefinisikan sebagai berikut:

“Kemiskinan adalah suatu situasi dimana seseorang atau rumah tangga mengalami kesulitan untuk memenuhi kebutuhan dasar, sementara lingkungan pendukungnya kurang memberikan peluang untuk meningkatkan kesejahteraan secara berkesinambungan atau untuk keluar dari kerentanan".

Dari definisi di atas, kita dapat melihat tiga tingkat kondisi yang perlu dipantau: (1) Kesejahteraan subjektif (subjective wellbeing atau disingkat SWB), (2) Kesejahteraan inti (kebutuhan dasar, seperti kekayaan materi, pengetahuan dan kesehatan), dan (3) Lingkungan pendukung (konteks).

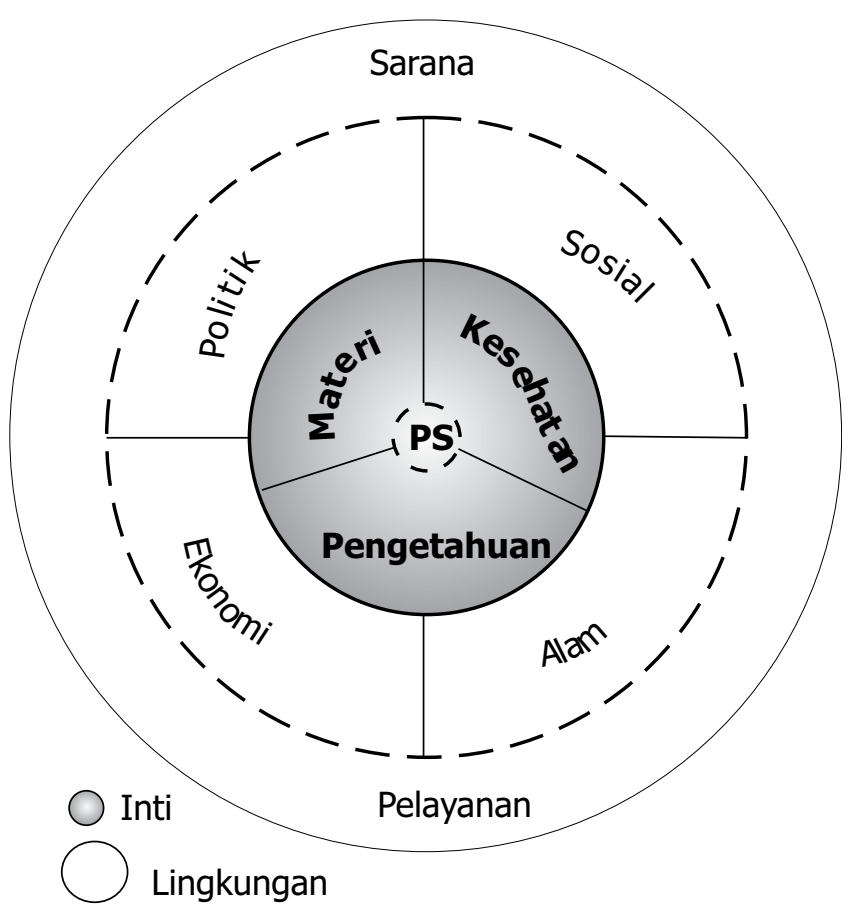

Gambar 1. Model kesejahteraan 
Lingkungan pendukung masih dibagi lagi menjadi dua, yaitu lingkungan sektoral (alam, ekonomi, politik dan sosial) dan lingkungan lintas sektoral (infrastruktur dan pelayanan) (lihat Gambar 1).

Perasaan kesejahteraan subjektif adalah kumpulan perasaan seseorang; bisa berupa perasaan sejahtera, rasa bahagia, rasa dihormati, rasa diakui, rasa miskin, rasa serba kekurangan, dan perasaan-perasaan sejenisnya. Perasaan ini bersifat sangat umum dan dipengaruhi oleh seluruh aspek kehidupan. Perasaan ini bisa saja bersifat sementara dan mungkin dipengaruhi oleh kejadian-kejadian sesaat. Rumah tangga yang baru bercerai, misalnya, pasti langsung merasa tidak bahagia, walaupun mungkin keadaan materi, pengetahuan, kesehatan dan lingkungan kehidupannya dalam kondisi baik. Oleh karena itu, di samping mengukur kesejahteraan subjektif, kita juga perlu mempertimbangkan aspek-aspek kehidupan lain yang lebih objektif. Walaupun aspek ini sangat subjektif, tetapi sangat penting untuk diukur karena merupakan hal yang paling inti dalam kesejahteraan. Ada banyak contoh yang menunjukkan orang kaya terkena penyakit karena perasaannya terganggu.

Kesejahteraan inti terdiri dari kebutuhan dasar yang bersifat material (kebendaan) maupun bukan material, yang mencakup aspek gizi dan kesehatan, pengetahuan, dan kekayaan materi. Dalam memantau kebutuhan dasar, informasi tentang bagaimana kebutuhan dasar tersebut didapatkan (atau tidak didapatkan), seberapa sulit atau mudah mendapatkannya, atau dari mana kebutuhan itu bisa didapat, bukan merupakan hal yang penting untuk diketahui. Informasi yang penting di sini adalah apakah responden mendapatkan pemenuhan kebutuhan dasar tersebut setidaknya dalam 12 bulan terakhir. Dengan demikian, pada saat rumah tangga dalam keadaan miskin, pemantauan kebutuhan dasar tidak memberikan informasi tentang potensi bagi rumah tangga tersebut untuk keluar dari kemiskinan di masa depan.
Lingkungan pendukung (konteks) adalah lingkungan kehidupan yang mempengaruhi kesejahteraan inti. Misalnya, ada dua anak dengan usia dan tingkat kecerdasan yang sama tetapi tinggal terpisah pada lingkungan yang berbeda (misalnya di dua daerah yang berbeda). Salah satu anak tersebut tinggal di daerah dengan lingkungan alam yang sehat, sumber daya alam yang terjangkau serta dikelola secara lestari, dan pemerintah memberikan dukungan bagi perkembangan anak ini sampai dewasa yaitu dengan menyediakan pendidikan berkualitas tinggi yang terjangkau oleh seluruh warga. Di lain pihak, anak yang lain tinggal di daerah dengan kondisi bertolak belakang: lingkungan alam yang rusak parah, sungai dan sumber air yang tercemar, sumber daya alam yang tinggal sedikit, serta pelayanan pendidikan yang sangat rendah. Dengan kondisi demikian, dalam 25 tahun ke depan dapat dipastikan kedua anak tersebut akan mengalami perkembangan yang jauh berbeda: anak yang tinggal di lingkungan yang mendukung akan jauh lebih maju dan berkembang karena kebutuhan kesehatan, pengetahuan dan materinya dapat dipenuhi tanpa kesulitan, yang pada akhirnya dapat memberikan perasaan sejahtera.

Dalam kaitannya dengan upaya penanggulangan kemiskinan, informasi lingkungan pendukung dapat memberikan gambaran tentang potensi suatu rumah tangga untuk keluar dari kemiskinan.

Sebetulnya, lingkungan pendukung dalam kenyataannya tidak terpisah dan terkotak-kotak, tetapi pengelompokan perlu dilakukan untuk mempermudah analisis.

Pengelompokan juga penting dilakukan agar pengambil keputusan di tingkat daerah dapat menghubungkannya dengan pembagian urusan atau tugas pokok dan fungsi (TUPOKSI). Lingkungan pendukung dibagi menjadi empat kelompok yaitu Politik, Ekonomi, Sosial, dan Alam (POLEKSAL). Lingkungan POLEKSAL dapat memastikan bahwa setiap rumah tangga mendapatkan kesempatan untuk memperbaiki kualitas kehidupannya dan sekaligus dapat 
mengurangi kerentanan terhadap kekurangan kebutuhan dasar secara berkesinambungan. Lingkungan lintas sektoral kelima - infrastruktur dan pelayanan - mempengaruhi seluruh lingkungan lainnya (lihat Gambar 1).

\section{Pengertian Pemantauan}

Pemantauan kemiskinan terdiri dari beberapa langkah. Dimulai dengan pengukuran indikator (wawancara), analisis, penyajian data dan rekomendasi, serta pengambilan keputusan; selanjutnya dampak tersebut kemudian diukur lagi lewat wawancara dan seterusnya. Seluruh tahapan tersebut terjadi dalam satu siklus (lihat Gambar 2).

Pemantauan kemiskinan bermanfaat untuk:

1. Menggambarkan tingkat kemiskinan di daerah berdasarkan indikator kemiskinan yang telah disepakati;

2. Memperoleh data kemiskinan dari seluruh penduduk desa yang dapat dikumpulkan pada tingkat kecamatan dan daerah;

3. Memberikan masukan untuk perencanaan pembangunan di daerah agar pembangunan lebih terarah pada peningkatan kesejahteraan masyarakat. Masukan ini dapat membantu menjelaskan "apa

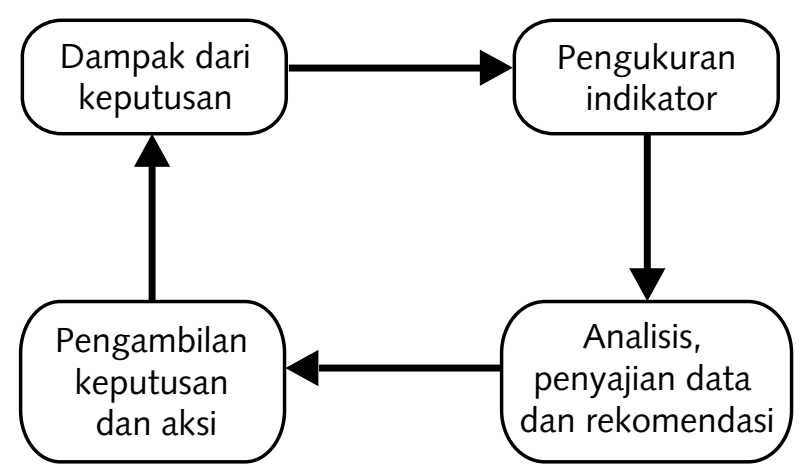

Gambar 2. Pemantauan dan siklus evaluasi yang sedang menjadi masalah, di mana terjadinya, dan apa yang perlu dilakukan "sehingga diharapkan penanggulangan kemiskinan dapat menjadi "arus utama" dalam pembangunan;

4. Menjadi bahan evaluasi pembangunan dan kinerja pemerintah daerah.

\section{Indikator dan Lembar Wawancara}

\section{Pengembangan Indikator}

Indikator kemiskinan mengungkapkan informasi tentang aspek kemiskinan tertentu yang mungkin berubah dari waktu ke waktu. Indikator merupakan elemen penting dalam kegiatan pemantauan. Kualitas indikator akan menentukan kualitas pemantauan. Pengembangan indikator dalam pemantauan kemiskinan di daerah dilakukan dengan cara mengumpulkan daftar calon indikator, mengujinya berdasarkan kriteria tertentu termasuk lewat uji lapangan, serta menyederhanakannya menjadi daftar yang lebih pendek.

Sumber-sumber yang digunakan untuk menggali dan mengumpulkan calon indikator adalah:

1. Persepsi masyarakat berdasarkan survei partisipatif (wawancara dan kelompok diskusi terfokus);

2. Persepsi perseorangan tentang kesejahteraan dan kemiskinan yang diperoleh dari studi kasus yang dilakukan secara mendalam;

3. Persepsi aparat pemerintah daerah berdasarkan satu lokakarya dan wawancara;

4. Model kesejahteraan BKKBN;

5. Model kemiskinan BPS;

6. Model kemiskinan internasional;

7. Teori-teori pembangunan;

8. Prinsip-prinsip pembangunan berkelanjutan;

9. Pemahaman Tim Pemantau. 
Pengujian lapangan dilakukan untuk memastikan bahwa indikator memenuhi kriteria yang telah ditetapkan (lihat Tabel 1), mudah dipahami, dan memang dapat menggambarkan tingkat kemiskinan sesuai dengan pemahaman kebanyakan orang. Selain itu, pengujian lapangan dilakukan untuk mengetahui apakah mekanisme pemantauan yang direncanakan cukup sederhana sehingga dapat dilaksanakan oleh pihak-pihak terkait dalam survei dengan mudah.

Daftar yang panjang memang dapat memberikan informasi yang lebih lengkap, tetapi akan menyulitkan dalam proses wawancara dan analisis data. Oleh karena itu penyederhanaan perlu dilakukan.

Penyederhanaan dilakukan dengan mengurangi jumlah indikator yang saling berhubungan (berkorelasi) kuat satu sama lain, sehingga (sedikit) indikator yang terpilih tetap

Tabel 1. Kriteria pemilihan indikator

\begin{tabular}{|l|l|}
\hline \multicolumn{1}{|c|}{ Kriteria } & \multicolumn{1}{c|}{ Catatan } \\
\hline Sederhana & $\begin{array}{l}\text { Mudah diterapkan dan dimengerti. Misalnya, } \\
\text { mengukur konsumsi telur, daging dan ikan lebih } \\
\text { mudah daripada mengukur asupan kalori harian. }\end{array}$ \\
\hline Dapat diukur & $\begin{array}{l}\text { Dapat diukur dengan menggunakan metode } \\
\text { tertentu. }\end{array}$ \\
\hline $\begin{array}{l}\text { Sesuai dengan } \\
\text { kondisi } \\
\text { setempat }\end{array}$ & $\begin{array}{l}\text { Indikator mencerminkan istilah serta tatanan } \\
\text { politik, ekonomi, sosial, dan alam setempat, } \\
\text { serta persepsi masyarakat tentang kemiskinan. } \\
\text { Misalnya, lantai tanah tidak cocok untuk menilai } \\
\text { kondisi rumah di daerah luar Jawa (mis: Kutai } \\
\text { Barat), karena lantai rumah penduduk paling } \\
\text { miskin sekalipun terbuat dari kayu. }\end{array}$ \\
\hline $\begin{array}{l}\text { Tepat dan } \\
\text { dapat } \\
\text { diandalkan }\end{array}$ & $\begin{array}{l}\text { Metode akan menghasilkan hasil yang sama } \\
\text { sekalipun dinilai oleh penilai lain. Hasilnya dapat } \\
\text { dipercaya. Misalnya, jumlah parabola merupakan } \\
\text { indikator yang baik, karena dapat diamati } \\
\text { langsung oleh pendata. }\end{array}$ \\
\hline $\begin{array}{l}\text { Cocok dengan } \\
\text { skala waktu }\end{array}$ & $\begin{array}{l}\text { Indikator dapat diukur dalam rentang waktu yang } \\
\text { tepat. Misalnya, dampak SMP yang dibangun } \\
\text { tahun ini tidak dapat diukur tahun ini juga. }\end{array}$ \\
\hline
\end{tabular}

berada pada kategori yang berlainan. Pengujian juga dilakukan untuk melihat korelasi antara kemungkinan kombinasi subset dan fulset calon indikator. Subset yang dipilih adalah yang paling dapat mengarah pada kesimpulan yang paling mendekati kesimpulan yang dihasilkan oleh fulset, atau yang memiliki tingkat korelasi paling tinggi. Selain uji korelasi, juga dilakukan uji coba dari sisi makna dan kebergunaan calon-calon indikator yang terkumpul dalam beberapa subset. Informasi lebih lanjut tentang pemilihan indikator disajikan dalam Modul 1 panduan ini.

Setelah melewati dua kali uji coba, akan diperoleh daftar pendek indikator. Daftar pendek inilah yang dijadikan daftar indikator resmi. Daftar indikator dan penjelasannya dapat dilihat pada modul pelatihan penjelasan indikator (Modul 5).

\section{Merancang Lembar Wawancara}

Lembar wawancara dikembangkan dengan menggunakan daftar indikator. Setiap indikator diubah menjadi satu pertanyaan. Pertanyaan dirumuskan berdasarkan makna dari indikator-indikator ini. Untuk setiap pertanyaan

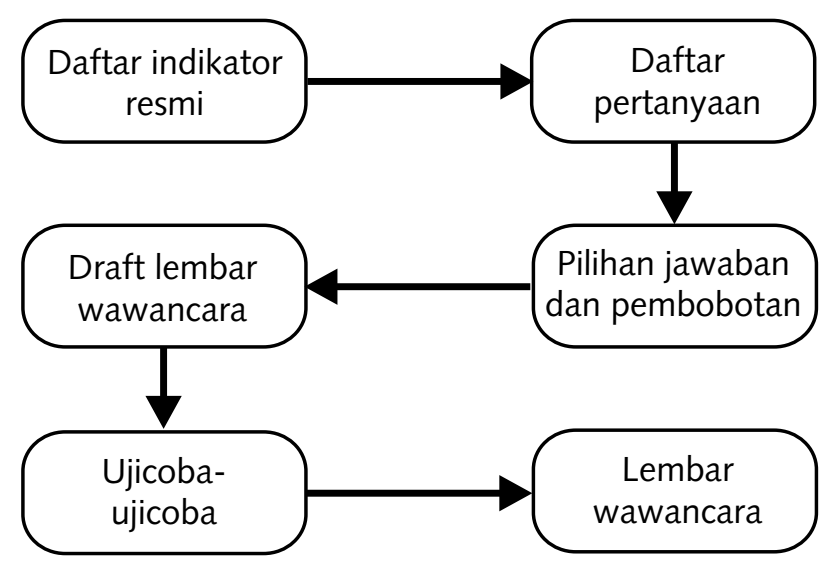

Gambar 3. Proses pengembangan lembar wawancara 
disediakan pilihan jawaban, sehingga pertanyaannya sendiri tetap tertutup. Setiap jawaban diberi nilai atau bobot yang mencerminkan kondisi miskin atau kritis, kondisi sedang (kadang-kadang dihilangkan), dan kondisi makmur atau sejahtera. Proses ini dilanjutkan sampai lembar wawancara selesai (lihat Gambar 3).

\section{Wawancara dan Aliran Data}

Wawancara merupakan tugas pendata desa. Akan ada satu orang pendata untuk setiap desa kecil (dengan jumlah responden sampai dengan 60 rumah tangga), dan lebih dari satu untuk setiap desa yang lebih besar. Pendata desa akan diutamakan dipilih dari para guru yang ada di dalam atau sekitar desa. Hal ini ditetapkan berdasarkan pengalaman dan pertimbangan: (1) tingkat pemahaman dan wawasan, (2) kemampuan komunikasi, dan (3) netralitas dalam masyarakat.

Sebelum pendataan desa dilakukan, pendata desa direkrut berdasarkan prosedur yang sudah ditentukan (lihat Modul 2). Pendata desa yang sudah direkrut kemudian diundang untuk mengikuti pelatihan pendata.

Pihak-pihak yang terlibat dalam pengumpulan, pengukuran, pengolahan dan analisis data adalah: pendata desa, petugas pemeriksa, petugas kecamatan dan Tim Pemantau (lihat Gambar 4).

Pengukuran indikator dilakukan melalui wawancara berdasarkan pertanyaan pada lembar wawancara yang telah disiapkan seperti telah dijelaskan sebelumnya. Pertanyaan pada lembar wawancara rumah tangga ditanyakan kepada rumah tangga. Jumlah rumah tangga yang diwawancarai minimal 20 rumah tangga, atau 33 persen per desa yang dilibatkan (salah satu yang lebih besar). Jika jumlah rumah tangga di suatu desa kurang atau sama dengan 20, maka seluruhnya harus disensus. Jika jumlahnya lebih dari 20
Tim Pemantau

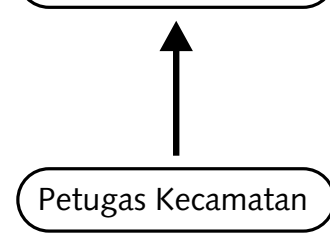

Data entry

Pemeriksaan lapangan

Analisis dan presentasi

Pemeriksaan kualitas

Penyerahan data ke kabupaten

Pengukuran indikator (wawancara)

Penyerahan data ke kecamatan
Pendata Kampung tetapi kurang dari 61, maka jumlah rumah tangga yang harus ditanya adalah 20 yang dipilih menggunakan sistem undian acak sederhana. Sedangkan jika jumlahnya 61 atau lebih, maka pendata desa harus memilih satu rumah tangga dari setiap 3 rumah tangga. Dengan cara ini, jumlah rumah tangga yang disurvei akan berkisar antara 32 hingga 35 persen. Keterangan lebih rinci dapat dilihat pada modul pelatihan pemilihan responden (Modul 3). Jawaban responden atas pertanyaan pada lembar wawancara akan menjadi data kemiskinan yang selanjutnya akan diolah menjadi informasi sesuai dengan tujuan pemantauan.

Teknik wawancara yang digunakan dapat dilihat pada modul pelatihan teknik wawancara (Modul 4), sedangkan penjelasan tentang lembar wawancara dapat dilihat pada Modul 5.

Setelah pendata desa selesai melakukan wawancara, lembar wawancara yang sudah diisi disegel dan dikirim langsung ke petugas pemeriksa. Petugas pemeriksa selanjutnya memeriksa lembar wawancara yang masuk untuk memastikan:

- Pemilihan responden sudah dilakukan sesuai prosedur

- Tidak ada satu pun pertanyaan yang kosong tanpa jawaban. 
Penjelasan rinci tentang cara memeriksa lembar wawancara yang sudah diisi dapat dilihat pada modul pelatihan pemeriksaan hasil wawancara (Modul 6).

Jika secara keseluruhan dilihat baik, maka petugas pemeriksa membayar honor pendata desa (sesuai dengan ketentuan).

Petugas pemeriksa juga membayar biaya perjalanan pendata desa untuk mengantar lembar wawancara yang sudah diisi (juga sesuai dengan besaran yang sudah ditetapkan).

Setelah seluruh lembar wawancara dari seluruh desa terkumpul, petugas pemeriksa membawa lembar wawancara terisi ini kepada Tim Pemantau.

Tim Pemantau akan memasukkan data dari lembar wawancara yang telah terisi ke dalam lembar kerja SPSS di komputer. Tim Pemantau bertugas memberikan bimbingan kepada petugas-petugas ini dan secara reguler melaksanakan pemeriksaan kualitas untuk memastikan bahwa data yang dimasukkan sama persis dengan apa yang ada di lembar wawancara yang telah terisi tadi. Penjelasan tentang pemasukan data dan pengawasan kualitasnya dijelaskan pada modul pelatihan mengisikan data ke dalam program SPSS (Modul 7).

Setelah pemasukan (entry) data selesai, tugas Tim Pemantau selanjutnya adalah melakukan kompilasi seluruh file yang terpisah di seluruh komputer agar menjadi satu file. Dengan demikian data sudah siap untuk dianalisis.

\section{Pengolahan dan Penyajian Data}

\section{Menghitung indeks}

Setelah lembar kerja SPSS diverifikasi, pengolahan data dapat dimulai. Salah satu pengolahan data yang paling penting adalah penghitungan indeks.
Sebelum penghitungan indeks dimulai, perlu dihitung kisaran nilai yang ada pada setiap indeks. Kisaran nilai dapat dilihat dari nilai terendah dan nilai tertinggi untuk setiap indikator pada indeks tersebut.

\section{Contoh:}

Pada indeks kekayaan materi terdapat tiga indikator yaitu Var 16, Var 17, dan Var 18. Dari lembar wawancara didapatkan kisaran nilai seperti terlihat pada Tabel 2.

Penghitungan indeks dilakukan dengan normalisasi data, dengan menggunakan rumus:

\begin{tabular}{|c|c|c|c|}
\hline Indeks & $\begin{array}{c}\text { (Jumlah skor yang } \\
\text { diperoleh) }\end{array}$ & & $\begin{array}{l}\text { (Jumlah skor } \\
\text { minimum) }\end{array}$ \\
\hline $\begin{array}{c}\text { Kekayaan } \\
\text { Materi }\end{array}$ & $\begin{array}{l}\text { (Jumlah skor } \\
\text { maksimum) }\end{array}$ & - & $\begin{array}{l}\text { (Jumlah skor } \\
\text { minimum) }\end{array}$ \\
\hline
\end{tabular}

Misalnya, jika salah satu responden menjawab seluruh pertanyaan pada indeks kekayaan materi, sehingga nilai yang diperoleh sebagai berikut:

$\operatorname{Var} 15=2, \operatorname{Var} 16=1$ dan $\operatorname{Var} 17=3$

Jumlah skor yang diperoleh $=2+1+3=6$

Jumlah skor maksimum $=3+3+3=9$

Jumlah skor minimum $=1+1+1=3$

Maka indeks kekayaan materi responden tersebut adalah: $[(6-3) /(9-3)] \times 100=50$

Tabel 2. Kisaran nilai indeks kekayaan materi

\begin{tabular}{|l|l|l|c|c|}
\hline \multicolumn{1}{|c|}{$\begin{array}{c}\text { Kode } \\
\text { indikator }\end{array}$} & \multicolumn{1}{|c|}{ Indikator } & Nilai & Min & Maks \\
\hline Var 15 & Standar rumah & $1,2,3$ & 1 & 3 \\
\hline Var 16 & $\begin{array}{l}\text { Memiliki sepeda motor } \\
\text { atau mesin ces }\end{array}$ & 1,3 & 1 & 3 \\
\hline Var 17 & $\begin{array}{l}\text { Memiliki parabola atau } \\
\text { kulkas }\end{array}$ & 1,3 & 1 & 3 \\
\hline Total & & 3 & 9 \\
\hline
\end{tabular}


Dari rumus tersebut, dapat dilihat bahwa nilai indeks terendah adalah 0 (nol) dan tertinggi adalah 100 (seratus).

Penghitungan indeks dimulai dengan sembilan indeks dasar yaitu: kesejahteraan subjektif, pengetahuan, kekayaan materi, kesehatan, politik, ekonomi, sosial, alam, dan infrastruktur dan pelayanan.

Setelah indeks dasar dihitung, langkah selanjutnya adalah menghitung indeks gabungan, yaitu: inti (kekayaan materi, kesehatan dan pengetahuan) dan konteks (politik, ekonomi, sosial, dan alam, serta infrastruktur dan pelayanan).

Penghitungan indeks gabungan dilakukan dengan cara menghitung rata-rata indeks dasar yang menjadi bagian dari indeks gabungan tersebut:

Rumus indeks inti adalah:

$$
\underset{\text { Inti }}{\text { Indeks }}=\frac{(\text { I. Materi }+ \text { I. Pengetahuan }+ \text { I. Kesehatan })}{3}
$$

Rumus indeks konteks (lingkungan pendukung) adalah:

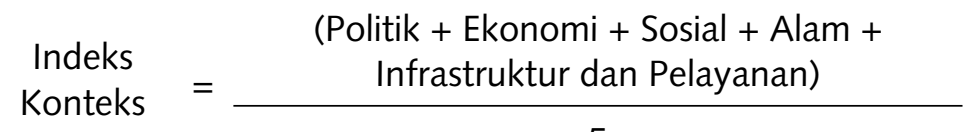
5

Pada bagian terakhir dapat dihitung indeks agregat total, yang menggabungkan seluruh indeks yang ada. Indeks agregat total sama dengan rata-rata penjumlahan indeks inti dan indeks konteks (tetapi tidak termasuk kesejahteraan subjektif).

Indeks agregat total dapat digunakan untuk memeringkatkan desa dalam menghitung ambang batas anggaran selama proses perencanaan (lihat 'Pengambilan Keputusan' di bawah). Tetapi, jangan menggunakan indeks komposit ini sebagai satu-satunya dasar untuk alokasi dana pembangunan! Seperti indeks komposit lainnya, indeks agregat menyimpan informasi penting yang hanya akan tampak jika kesembilan indeks kesejahteraan seluruhnya dipelajari. Indeks-indeks ini dapat dihubungkan dengan lebih baik dengan sektor-sektor pemerintah dan harus lebih diutamakan dalam merencanakan program pengurangan kemiskinan sektoral dan program pembangunan.

\section{$\underline{\text { Klasifikasi Nilai }}$}

Batas kemiskinan dibuat dengan garis kemiskinan yang digambar berdasarkan klasifikasi nilai indeks. Klasifikasi nilai indeks harus mencerminkan jawaban dalam lembar wawancara. Karena penghitungan dilakukan pada seluruh indeks, maka klasifikasi juga harus dibuat untuk setiap indeks.

\section{Contoh:}

Lihat kembali kisaran nilai indeks kekayaan materi pada Tabel 1. Ada dua indikator dengan nilai 1 dan 3, dan satu indikator dengan nilai 1, 2 dan 3. Dalam lembar wawancara kita dapat melihat bahwa nilai satu selalu mewakili kondisi miskin, sedangkan nilai 3 mewakili kondisi sejahtera. Jika ada nilai tengah (nilai 2), maka nilai tersebut mencerminkan keadaan sedang. Dengan demikian, batas kemiskinan adalah nilai 1. Pada indikator yang memiliki nilai tengah (nilai 1, 2 dan 3), nilai 1 berarti setara dengan 33,33 pada angka indeks (setelah normalisasi). Pada indikator yang tidak memiliki nilai tengah (nilai 1, 3), nilai 1 setara dengan 50 pada angka indeks. Jika kita hitung rata-rata batas kemiskinan, maka kita akan mendapatkan batas kemiskinan untuk indeks kekayaan materi.

$\operatorname{Var} 15=$ tiga jenis nilai $=100 / 3=33,33$

$\operatorname{Var} 16=$ dua jenis nilai $=100 / 2=50$

$\operatorname{Var} 17=$ dua jenis nilai $=100 / 2=50$

Rata-rata: $(33.33+50+50) / 3=44,44$ 
Untuk mengurangi resiko kesalahan, angka tersebut harus dibulatkan ke atas menjadi 45. Batas "sedang" didapat dengan mengurangi nilai indeks maksimum (100) dengan batas miskin (45) menjadi 55. Dengan demikian, klasifikasi indeks kekayaan materi adalah sebagai berikut:

- Miskin (0-45)

- Sedang (46-54)

- Sejahtera (55-100).

Buatlah klasifikasi untuk seluruh indeks berdasarkan lembar wawancara pada uji coba kedua. Bandingkan jawaban Anda dengan kunci jawaban pada Lampiran 2.

Garis kemiskinan akan memudahkan penentuan rumah tangga, desa, atau kecamatan yang miskin. Jika pendataan dilakukan dengan sensus, rumah tangga mana yang paling miskin dapat ditentukan dengan mudah. Dengan konsep pemantauan ini, juga dapat diketahui informasi kondisi miskin dalam aspek apa, sehingga langkah-langkah penanggulangannya dapat diperkirakan secara akurat.

\section{Penyajian Data}

Angka indeks akan memberi gambaran kondisi kehidupan suatu desa dengan menunjukkan perasaan masyarakat, pemenuhan kebutuhan dasar (inti) dan kondisi lingkungan pendukung (konteks) seperti terlihat pada Gambar 5.

Hal yang sama dapat dilakukan di tingkat kecamatan. Pada bagan tingkat kecamatan, kita dapat menunjukkan indeks agregat. Kita juga dapat menunjukkan indeks spesifik per desa (misalnya, indeks alam) seperti terlihat pada Gambar 6).

Data hasil pemantauan ini juga akan sangat bermanfaat jika digabungkan dengan data dasar kependudukan (lihat Gambar 7).

Sinergi data ini akan sangat bermanfaat terutama dalam program pemberian bantuan bagi rumah tangga, keluarga, atau penduduk miskin. Hal ini karena dengan sinergi ini, seluruh data kependudukan dan data kemiskinan dapat dilihat secara bersama-sama dengan mudah. Dengan

Indeks Kesejahteraan Desa Jeruk Tahun 1234

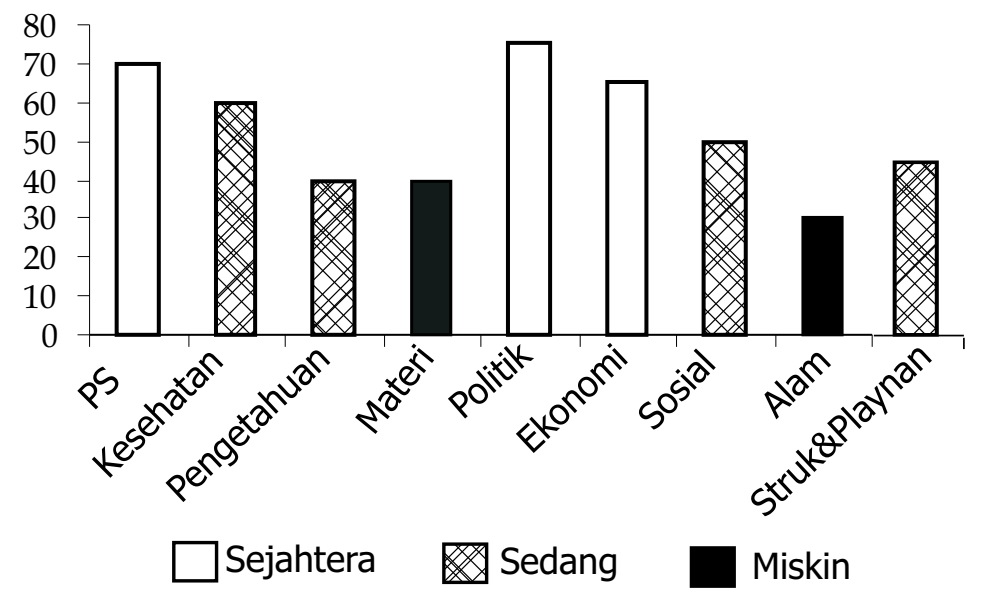

Gambar 5. Contoh indeks kesejahteraan di tingkat desa

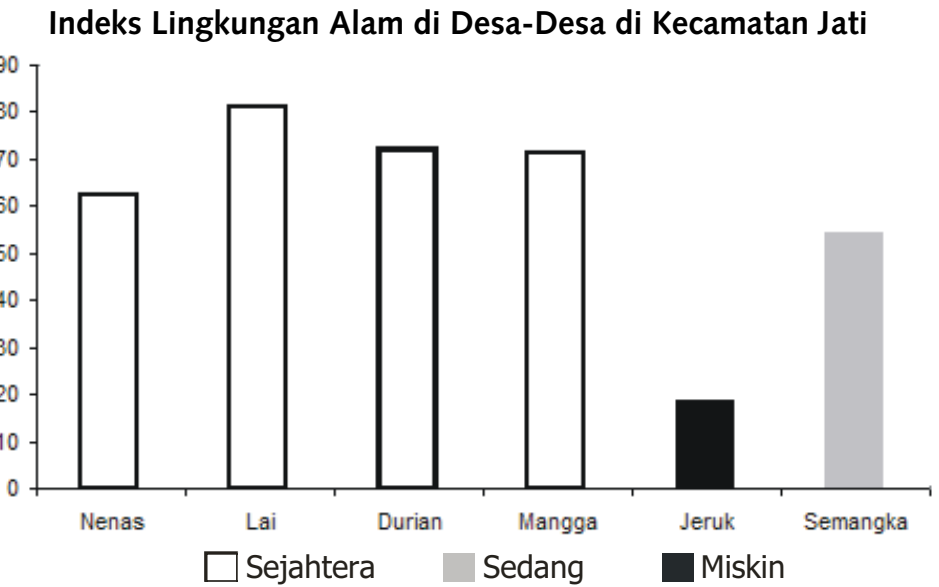

Gambar 6. Indeks kesejahteraan agregat pada tingkat kecamatan 


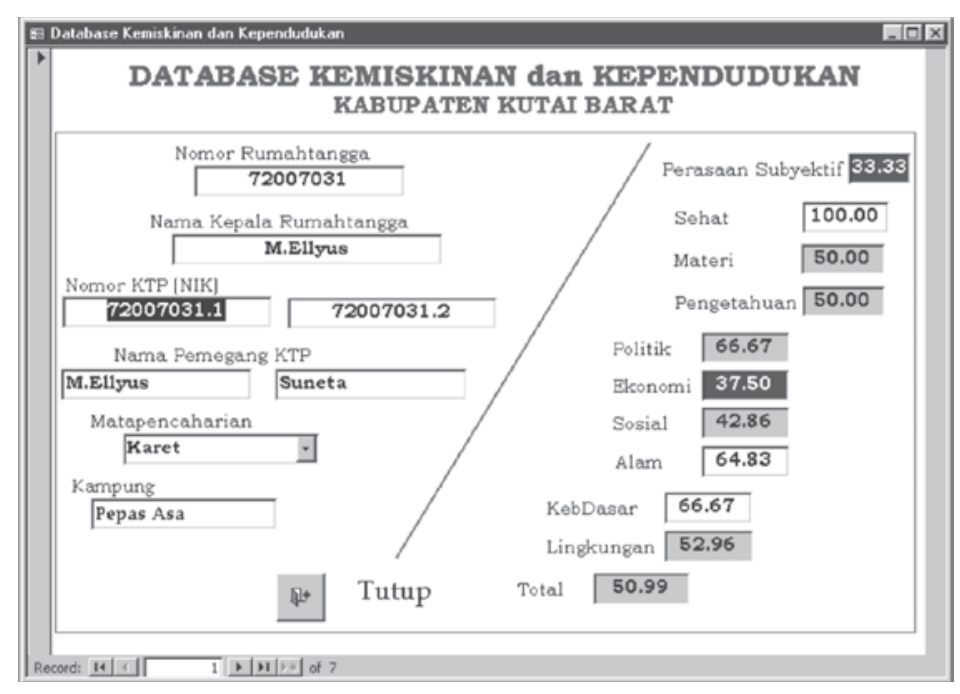

Gambar 7. Database kependudukan dan kemiskinan terpadu

demikian, dasar pertimbangan dalam pengambilan keputusan dapat lebih lengkap. Selain itu, database terpadu ini penting karena kebijakan penanggulangan kemiskinan berkaitan erat dengan kebijakan pengelolaan kependudukan daerah. Misalnya, migrasi penduduk yang tak terkendali berpotensi meningkatkan jumlah penduduk miskin yang berasal dari luar daerah.

Jika seluruh indeks dihubungkan dengan tugas pokok dan fungsi (TUPOKSI) serta uraian tugas satuan-satuan kerja yang ada di pemerintahan, maka data hasil pemantauan ini dapat digunakan untuk melakukan evaluasi kinerja satuan-satuan kerja pemerintah daerah.

Penyajian data indeks kemiskinan bersama-sama dengan informasi lokasi akan membantu pemerintah daerah dalam menentukan prioritas lokasi dan prioritas urusan. Sebagai contoh: Jika diketahui situasi di Kecamatan Jati menunjukkan indeks pengetahuan dan ekonomi yang buruk, maka Bappeda dan Pemerintah Kecamatan Jati dapat menentukan sektor-sektor prioritas di daerah tersebut, misalnya: pendidikan, pertanian, kehutanan, perdagangan. Selain itu, perlu juga didapatkan data yang lebih lengkap tentang keadaan infrastruktur dan pelayanan di daerah tersebut untuk mengetahui infrastruktur dan pelayanan yang perlu didukung terkait dengan sektor prioritas yang telah ditetapkan.

Selain penyajian dalam bentuk grafik batang (seperti Gambar 5 dan 6), informasi juga dapat disajikan secara lebih umum dengan skala wilayah yang lebih luas, yaitu dengan menempatkannya pada peta daerah (misalnya: kabupaten). Setiap desa dapat dilingkari dan diberi simbol yang menunjukkan tingkat kemiskinan di desa tersebut, sedangkan poligon kecamatan juga dapat diberi simbol sehingga dapat dibedakan tiga klasifikasi tingkat kesejahteraan yaitu miskin, sedang, dan sejahtera. Simbol-simbol tersebut mencerminkan indeks keseluruhan (lihat Gambar 8).

Aktivitas pemantauan kemiskinan harus dilakukan secara teratur (misalnya setiap dua atau tiga tahun). Jika dilakukan

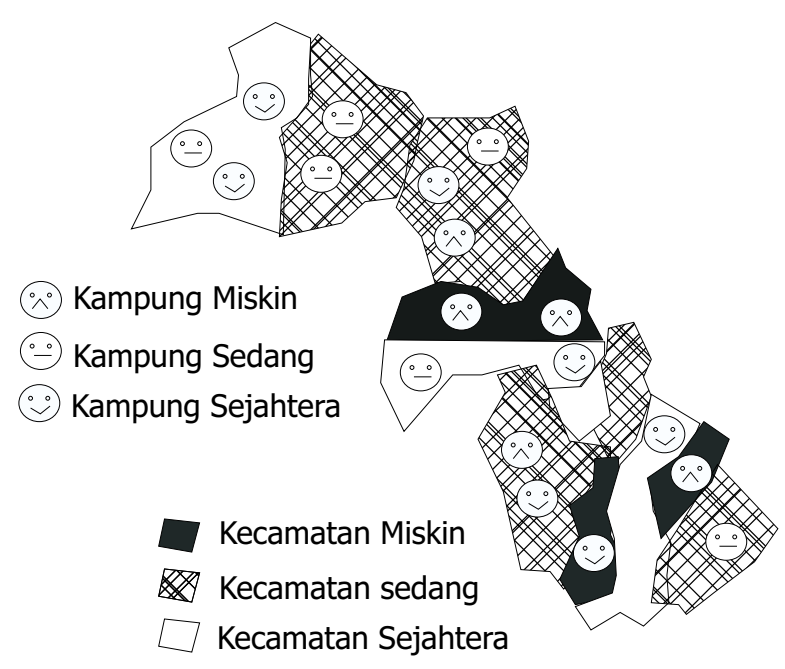

Gambar 8. Penyajian data dalam bentuk peta 
secara teratur, maka perkembangan dan kecenderungan tingkat kemiskinan, misalnya pada tingkat desa, akan dapat diamati. Gambar perubahan dan kecenderungan ini sangat bermanfaat untuk mengevaluasi kinerja kepala daerah. Hal ini akan membantu dalam membangun sistem penghargaan dan hukuman (reward and punishment) yang lebih obyektif. Di tingkat daerah, hal ini dapat menjadi alat untuk menilai kinerja kepala daerah secara lebih obyektif dan untuk mengurangi kepentingan-kepentingan politik jangka pendek yang biasanya tidak bermanfaat bagi masyarakat luas.

Gambar perkembangan dan kecenderungan juga dapat menjadi pelajaran bagi pemerintah daerah mengenai apa yang bisa dan tidak bisa meningkatkan kesejahteraan masyarakat, sehingga dapat menjadi gagasan untuk merancang rencana tindakan untuk periode selanjutnya. Penjelasan lebih rinci tentang penghitungan indeks dan penyajiannya dapat dilihat pada Modul 8 dan 9. Contoh penyajian data dalam bentuk perkembangan dan kecenderungan dapat dilihat pada Gambar 9.

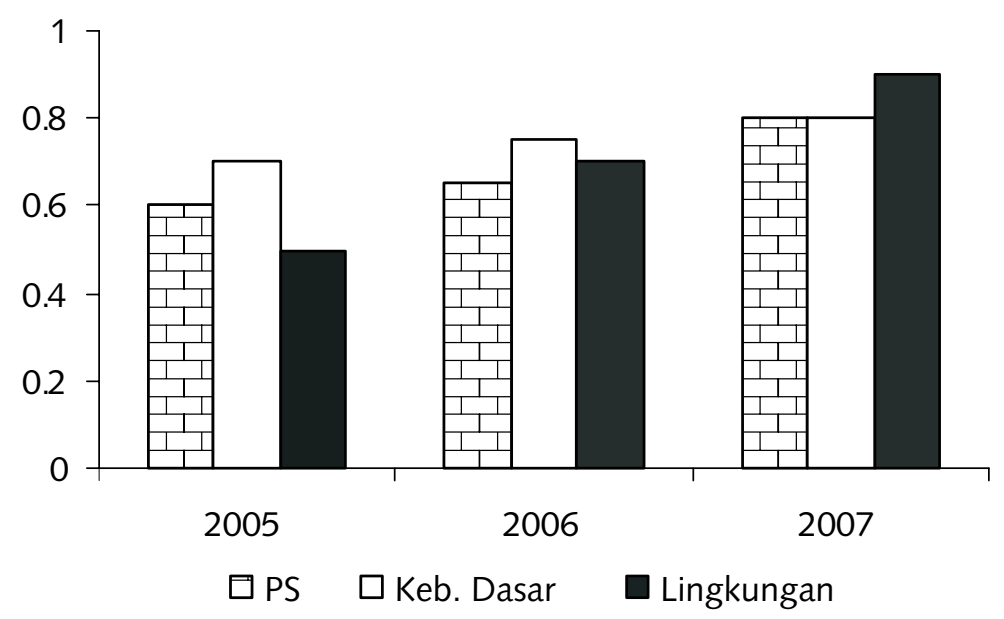

Gambar 9. Penyajian perubahan indeks kesejahteraan tahunan

\section{Pemeriksaan Lapangan}

Pemeriksaan lapangan bertujuan untuk memeriksa desa-desa yang dinilai memiliki kejanggalan dalam datanya. Kejanggalan tersebut dapat disebabkan oleh manipulasi data, kesalahan pemilihan responden, atau kesalahpahaman petugas pendata desa. Oleh karena itu, pemeriksaan akan dilakukan setelah analisis data pendahuluan diselesaikan. Untuk lebih rinci, lihat Modul 10 tentang pemeriksaan lapangan.

\section{Pengambilan Keputusan}

Langkah terakhir dalam siklus pemantauan adalah pengambilan keputusan. Data pemantauan akan sangat membantu dalam melakukan perencanaan dan evaluasi kinerja, baik untuk program bantuan maupun program pemberdayaan.

\section{Perencanaan}

Data pemantauan dapat memberikan informasi langsung tentang:

(1) Lokasi prioritas

Lokasi prioritas membantu menjawab pertanyaan 'dimana';

(2) Urusan prioritas

Urusan prioritas membantu menjawab pertanyaan 'apa'.

Jika kedua informasi ini digabungkan, maka pemerintah daerah akan memahami tentang apa dan di mana masalah kemiskinan yang sedang terjadi dengan lebih baik.

Kedua prioritas di atas dapat digunakan sebagai bahan diskusi dalam Musyawarah Perencanaan Kecamatan (Musrencam) dan Musyawarah Perencanaan Kabupaten/Kota. Kedua forum ini dapat sekaligus berfungsi sebagai diskusi kelompok terfokus untuk membahas survei. 
Badan Perencanaan Pembangunan Daerah (Bappeda), dibantu oleh Tim Pemantau, dapat membuat daftar temuan yang menjelaskan prioritas sektoral pada setiap lokasi (desa atau kecamatan). Data ini akan lebih lengkap lagi jika disajikan bersama dengan plafon anggaran. Data plafon anggaran dibuat berdasarkan Arah Kebijakan Umum (AKU) di tingkat daerah. Data ini sebaiknya dibuat per sektor dan per lokasi.

Pembahasan yang dapat dilakukan di Musrencam antara lain:

(1) Membahas apakah temuan dari pemantauan tersebut masuk akal;

(2) Membandingkan keadaan desa-desa yang disurvei yang sebenarnya dengan data yang mewakilinya;

(3) Mendiskusikan masalah apa yang paling mungkin menjadi penyebab;

(4) Membuat peringkat masalah (skala) berdasarkan data temuan dan eksplorasi, dengan mempertimbangkan, antara lain:

- Tingkat keseriusan dampak yang mungkin terjadi jika masalah tersebut tidak terselesaikan,

- Seberapa banyak orang yang terkena dampak masalah tersebut,

- Jumlah masalah lain yang akan timbul jika masalah tersebut tidak dipecahkan;

(5) Menentukan tindakan-tindakan yang sekiranya akan efektif memecahkan masalah. Untuk setiap tindakan, tentukan juga jangka waktu serta skalanya, apakah jangka pendek, menengah atau panjang. Selain itu, apakah dilakukan pada skala desa, lintas desa, kecamatan, atau lintas kecamatan;

(6) Membuat peringkat prioritas untuk tindakan ini. Pemeringkatan dapat dilakukan dengan mempertimbangkan, antara lain:

- Relevansi calon tindakan dengan penyebab masalah yang sedang dipelajari, yaitu bahwa setiap tindakan yang diambil harus ditujukan untuk memecahkan masalah prioritas,
- Peringkat masalah yang menjadi target untuk dipecahkan,

- Tingkat peluang keberhasilan,

- Kesesuaian dengan dana yang tersedia.

Tindakan dapat berupa tindakan langsung (proyek) atau tidak langsung (peraturan). Contoh tindakan langsung misalnya beasiswa dan bantuan modal, sedangkan contoh tindakan tidak langsung misalnya peraturan yang mewajibkan perusahaan untuk membantu pendidikan di daerah kerjanya, atau peraturan yang mewajibkan lembaga keuangan untuk menyediakan kredit lunak pada pengusaha kecil dan menengah.

Forum Musrencam dapat memutuskan dua hal: (1) proyek apa yang perlu diimplementasikan, di mana, dan untuk berapa lama, dan (2) peraturan apa yang perlu ditetapkan dan untuk area apa.

Hasil pembahasan ini dapat dibawa ke musyawarah perencanaan kab/kota untuk menjadi pembahasan lebih lanjut. Pembahasan pada tingkat daerah (kabupaten/kota) lebih berfungsi untuk:

(1) Sinergi program

(2) Koordinasi tindakan lintas kecamatan

(3) Plafon anggaran Satuan Kerja Pemerintah Daerah (SKPD).

Hasil dari pembahasan antar kecamatan dapat digunakan oleh satuan-satuan kerja pemerintah daerah sebagai bahan masukan penting untuk mengadaptasi Rencana Kerja dan Anggaran Satuan Kerja (RKA-SKPD) masing-masing. Dengan demikian setiap satuan kerja mengetahui fokus kerja untuk tahun berikutnya, baik fokus lokasi maupun fokus tindakan.

\section{Evaluasi}

Pemantauan harus dilakukan secara berkala, sehingga data 
tersebut dapat menjadi data seri yang bila dibandingkan satu sama lain akan sangat bermanfaat bagi evaluasi.

Pimpinan daerah dapat melihat perkembangan keadaan setiap urusan untuk setiap lokasi. Dari perkembangan urusan dapat diketahui kinerja satuan-satuan kerja yang bertanggung jawab pada urusan tersebut. Kinerja para camat atau kepala desa juga akan dapat dilihat dengan jelas.
Dengan demikian, pimpinan daerah dapat mengambil keputusan berdasarkan data dan informasi yang lebih tepat. $\mathrm{Hal}$ ini dapat mengurangi pengaruh-pengaruh kepentingan sesaat dari para pihak yang terlibat dalam politik di daerah. Sistem penghargaan dan hukum (reward and punishment) juga dapat diterapkan secara lebih obyektif, misalnya dihubungkan pada mekanisme promosi jabatan. 

Pengembangan Indikator Kemiskinan Lokal 


\section{Pengembangan Indikator Kemiskinan Lokal}

Sebelum mengembangkan indikator, Tim Pemantau harus sudah dibentuk. Tim Pemantau beranggotakan antara empat sampai tujuh orang. Tugas Tim Pemantau adalah mengawasi seluruh aktivitas pengembangan sistem pemantauan.

Anggota Tim Pemantau harus memenuhi satu atau lebih dari kriteria di bawah ini:

- Memiliki pemahaman yang baik tentang pola kehidupan warga setempat.

- Berpengalaman dalam survei atau pengembangan indikator.

- Bekerja dan berpikir logis.

Calon indikator dapat diperoleh melalui diskusi kelompok atau wawancara. Calon indikator ini digunakan dalam survei uji coba pertama untuk mendapatkan gambaran umum tentang keadaan yang ada.

Hasil survei uji coba pertama digunakan selama proses untuk menilai calon indikator. Jika jumlah calon indikator masih terlalu banyak, maka diperlukan pengurangan lebih lanjut.

Semakin banyak jumlah indikator, informasi yang diperoleh akan semakin lengkap, tetapi wawancara yang diperlukan akan semakin panjang. Hal ini tidak hanya mempengaruhi waktu dan dana yang diperlukan, tetapi juga mempengaruhi akurasi informasi karena responden mungkin menjadi tidak sabar atau lelah selama wawancara yang panjang. Dengan demikian harus dicari jumlah indikator yang optimal yang dapat memberikan informasi yang paling mendekati kenyataan sesuai keadaan.
Jumlah indikator dapat dikurangi dengan menggunakan analisis korelasi. Prinsipnya ialah menghasilkan seperangkat kecil indikator (subset) dari perangkat indikator keseluruhan (fulset) yang paling mewakili informasi. Setelah subset tersebut dikumpulkan, perlu dilakukan survei uji coba sekali lagi sebelum digunakan dalam pemantauan resmi.

Berikut uraian yang lebih rinci tentang langkah-langkah dalam mengembangkan indikator.

\section{Mengumpulkan Daftar Panjang Calon Indikator (Fulset)}

Calon indikator dapat dikumpulkan melalui diskusi kelompok. Dalam diskusi kelompok semacam itu, kita dapat menjajagi:

- Persepsi peserta tentang kemiskinan, melalui pertanyaan seperti:

- Apakah ciri khas warga miskin atau rumah tangga miskin?

- Dalam situasi seperti apa Anda merasa miskin?

- Penyebab kemiskinan, melalui pertanyaan seperti:

- Apakah yang menyebabkan kemiskinan?

- Mengapa Anda miskin?

Persepsi sering terkait dengan inti kesejahteraan dan uang, sedangkan penyebab kemiskinan sering dikaitkan dengan lingkungan pendukung (konteks).

Informasi yang diperoleh kemudian diterjemahkan ke dalam frasa netral, seperti "sangat sulit memperoleh makanan" dapat diubah menjadi frasa netral seperti "ketersediaan makanan". Penyederhanaan ini akan membantu dalam menetapkan calon indikator.

Kuantifikasi indikator (contoh Skor 1: makanan sering tidak tersedia; Skor 2: makanan tidak tersedia tidak selalu tersedia; Skor 3: makanan selalu tersedia) akan dikembangkan dalam pilihan jawaban pada lembar wawancara. 
Calon indikator yang telah dikumpulkan selanjutnya dibahas dalam rapat Tim Pemantau untuk memastikan bahwa indikator-indikator tersebut memenuhi kriteria indikator (lihat Kotak 1 pada Konsep Pemantauan) dan dapat digunakan selama pemantauan.

Untuk mendapatkan masukan yang lengkap mengenai calon indikator, sejumlah diskusi dengan perwakilan dari berbagai kelompok yang ada di masyarakat kelompok perlu dilakukan. Kelompok tersebut antara lain:

- Masyarakat pedesaan. Kelompok ini selanjutnya dapat dipecah agar setiap sub kelompok, seperti perempuan, pemuda, elit, non-elit, terwakili. Masyarakat yang dipilih haruslah masyarakat yang secara umum dapat dikatakan miskin.

- Petugas dari pemerintah daerah. Jika terbentur kesulitan untuk mengundang ke dalam satu pertemuan, wawancara (di tempat kerja mereka) dapat dijadikan alternatif.

- Kelompok masyarakat sipil dan akademisi. Kelompok ini sering terlibat dalam penelitian atau berinteraksi langsung dengan masyarakat. Wawancara dapat dilakukan dengan individu yang dianggap ahli atau berpengetahuan perihal penyebab kemiskinan tetapi tidak memiliki kesempatan untuk berpartisipasi dalam diskusi kelompok.

\section{Survei Uji Coba Pertama}

Survei uji coba pertama dilakukan pada kelompok masyarakat (desa) yang dapat mewakili suatu daerah. Sebelum pendataan dilakukan, terlebih dahulu harus disiapkan lembar wawancara berdasarkan daftar indikator yang telah ditetapkan. Untuk memastikan konsistensi penghitungan skor dan indeks, jawaban harus dibatasi dengan tiga alternatif. Ketiga pilihan tersebut harus mencerminkan kondisi kritis (skor 1), kondisi menengah (skor 2) dan kondisi sejahtera (skor 3). Untuk pertanyaan dengan jawaban ya/tidak, harus digunakan skor 1 (kritis) dan skor 3 (sejahtera). Modul 2-5 memuat penjelasan lebih lanjut tentang metode survei.

\section{Penilaian Calon Indikator}

\section{Memeriksa Frekuensi Jawaban}

Salah satu kriteria indikator adalah bahwa indikator dapat digunakan untuk membedakan antara rumah tangga yang miskin dan sejahtera. Kriteria ini dapat diperiksa dengan melakukan analisis frekuensi jawaban. Indikator yang jawabannya hampir seragam (lebih dari 80 persen) pada satu pilihan jawaban tertentu dapat diasumsikan tidak memenuhi kriteria sederhana ini.

\section{Contoh:}

Jika pada suatu desa lebih dari 80 persen masyarakatnya mengatakan kualitas air dalam kondisi sedang, maka indikator kualitas air tidak dapat membedakan kemiskinan masyarakat di desa tersebut.

Walaupun demikian, dalam hal ini Anda perlu hati-hati karena ada kemungkinan indikatornya baik, tetapi pilihan jawaban yang tersedia tidak dapat membedakan anggota masyarakat tertentu. Artinya, masalahnya bukan pada indikator tetapi pada pilihan jawaban dalam lembar wawancara.

\section{Contoh:}

Indikator untuk penyelesaian konflik dapat memiliki tiga keadaan: (1) konflik tidak pernah dapat diselesaikan melalui cara damai; (2) konflik kadang-kadang tidak dapat diselesaikan melalui cara damai; (3) konflik selalu dapat diselesaikan dengan cara damai. Tetapi, pada uji coba tidak ada responden yang memberi skor satu (1) Ini berarti, indikator tersebut tidak dapat membedakan ketiga kelompok yang ada di masyarakat. Jalan keluarnya ialah menggunakan dua skor saja (konflik kadang-kadang dapat diselesaikan dengan cara damai, konflik selalu dapat diselesaikan dengan cara damai) atau mencari kategori ketiga yang 'tidak setegas' (1), misalnya, konflik sering tidak dapat diselesaikan dengan cara damai. 


\section{Memeriksa Kriteria Berdasarkan Maknanya}

Selain pemeriksaan lewat frekuensi jawaban, Anda juga dapat memeriksa seluruh indikator berdasarkan maknanya untuk melihat pemenuhannya terhadap kriteria yang telah ditetapkan.

\section{Contoh:}

Indikator gergaji mesin dalam indeks kepemilikan materi mungkin tidak memenuhi kriteria 'tepat dan dapat diandalkan', karena pada saat ini pemerintah dan aparat keamanan sedang melancarkan operasi anti pembalakan liar. Akibatnya, sangat besar kemungkinan, responden tidak akan menjawab pertanyaan ini dengan jujur. Walaupun dari analisis korelasi, indikator gergaji mesin sangat baik karena dapat mewakili banyak barang-barang rumah tangga lainnya, tetapi dalam konteks ini indikator tersebut tidak dapat diterima sebagai pilihan yang tepat.

\section{Analisis Pemahaman Umum}

Pemahaman umum Anda tentang salah satu atau beberapa desa atau rumah tangga dapat digunakan untuk menguji calon indikator.

\section{Kondisi desa berdasarkan pengetahuan ahli}

Anda dapat membuat grafik batang indeks kemiskinan (seperti dijelaskan pada modul 9) untuk desa-desa yang Anda ketahui. Perhatikan grafik batang tersebut dan putuskan apakah hasil tersebut masuk akal.

\section{Contoh:}

Dengan melihat grafik batang indeks kemiskinan di Desa Durian (Modul 9), pikirkan apakah Anda setuju bahwa ratarata warga Desa Durian dikatakan hampir sejahtera, dan pasti tidak dapat dikatakan miskin. Di sini juga tampak jelas bahwa masalah terbesar mereka adalah masalah lingkungan politik, sedangkan kebutuhan dasar mereka relatif terpenuhi dengan baik. Jika Anda setuju dengan pernyataan ini, Anda dapat mempercayai calon indikator di atas.

\section{Peringkat Desa}

Anda juga dapat melihat peringkat desa pada indeks agregat total (seperti terlihat pada Modul 9). Pikirkan apakah Anda setuju dengan peringkat kemiskinan desa-desa tersebut.

Analisis ini dapat dilakukan melalui diskusi kelompok, dengan mengundang beberapa wakil dari desa-desa tersebut. Sangat penting untuk dicatat bahwa Anda tidak boleh mendengar pendapat hanya dari satu orang saja karena pemahaman umum setiap orang bisa salah walaupun orang tersebut adalah warga setempat. Oleh karena itu diperlukan diskusi kelompok.

Jika hasil analisis pemahaman umum menyatakan bahwa ada kejanggalan, jangan langsung menyalahkan calon indikator. Periksa lagi apakah pendataan dilakukan dengan benar. Misalnya, dalam uji coba kedua di Kutai Barat, dapat dilihat bahwa ada kejanggalan pada data untuk satu desa (Desa A) yang indeks totalnya jauh di bawah dua desa yang berbatasan. Padahal ketiga desa ini memiliki kemiripan gaya hidup dan ketiganya adalah pemekaran dari satu desa. Setelah diperiksa, ternyata pendataan di Desa A tidak dilakukan dengan benar. Pendata mengganti lebih dari 20 persen responden terpilih, dan memilih rumah tangga yang terlihat miskin. Pemilihan responden yang bias inilah yang menyebabkan indeks Desa A menjadi jauh lebih rendah dibandingkan dengan dua desa tetangganya.

\section{Peringkat Rumah Tangga}

Pemeriksaan lebih rinci dapat dilakukan terhadap peringkat rumah tangga berdasarkan indeks total rumah tangga. 
Siapkan daftar data yang menampilkan peringkat rumah tangga dari hasil penghitungan indeks, kemudian bagikan daftar tersebut kepada diskusi kelompok dari desa itu (jangan diberikan dalam urutan peringkat). Tanyakan pada mereka peringkat kemiskinan rumah tangga tersebut berdasarkan pemahaman mereka. Bandingkan pemeringkatan yang dibuat oleh kelompok diskusi dan pemeringkatan yang Anda buat lewat penghitungan indeks. Jika kedua pemeringkatan tersebut identik atau sama, maka indikator itu dapat dipercaya.

Seperti telah dijelaskan sebelumnya, pemeriksaan pemahaman masyarakat harus dilakukan lewat diskusi kelompok (minimal 5 orang). Peserta diskusi kelompok harus berasal dari latar belakang yang beragam, misalnya dari kelompok keluarga yang berbeda, jenis kelamin yang berbeda, organisasi desa yang berbeda, dll. Kelompok diskusi tersebut sedapat mungkin mewakili cara pandang desa tersebut.

Calon indikator yang lulus pengujian ini ditetapkan dalam daftar indikator lengkap (fulset).

\section{Mengurangi Jumlah Indikator}

Jumlah indikator dapat dikurangi dengan menggunakan analisis korelasi. Analisis korelasi dilakukan untuk memilih subset terbaik yang memberikan jawaban yang paling mirip dengan fulset.

Contoh:

Jika hampir seluruh rumah tangga yang memiliki televisi juga memiliki antena parabola, maka Anda cukup mengambil parabola untuk mengetahui kepemilikan materi. Mengapa? Karena jawaban dari kedua indikator itu (televisi dan antena parabola) akan mirip, sehingga menunjukkan profil rumah tangga yang hampir sama. Dengan kata lain, jika televisi dijadikan indikator untuk menyatakan suatu desa miskin, akan dapat dipastikan bahwa desa tersebut miskin pula jika indikatornya parabola. Pemilihan ini juga dipengaruhi oleh pertimbangan praktis karena antena parabola biasanya dipasang di luar rumah dan mudah terlihat sehingga pendataan akan lebih mudah dan lebih akurat karena responden tidak bisa berbohong.

Subset dan fulset adalah kumpulan indikator dalam satu kategori. Misalnya, dalam lingkungan ekonomi, jika terdapat 10 calon indikator, maka Anda perlu mencari kemungkinan kombinasi yang dapat mewakili keseluruhan. Kesepuluh calon indikator adalah fulset, sedangkan kombinasi dari beberapa indikator adalah subset. Di sini Anda harus menguji seluruh kemungkinan subset dan mencari subset yang memiliki hubungan paling kuat dengan fulset. Dengan kata lain, Anda perlu mendapatkan subset indikator yang memberikan jawaban yang paling mirip dengan fulset.

\section{Contoh:}

Fulset untuk lingkungan ekonomi adalah: V1, V2, V3, V4, V5, V6, V7, V8 dan V9. Berdasarkan kesepakatan Tim Pemantau, jumlah indikator untuk lingkungan ekonomi akan dibatasi hingga tiga saja (didasarkan pada analisis praktis, juga berdasarkan input dari hasil PCA). Hal ini berarti ada enam indikator yang harus dihilangkan.

Karena kita hanya membutuhkan tiga indikator, berarti setiap subset akan memiliki tiga indikator. Karena fulset memiliki sembilan indikator, berarti ada 84 kemungkinan subset.

Hasil untuk fulset diperoleh dengan menjumlahkan skor seluruh indikator untuk setiap responden. Hasil untuk subset diperoleh dari skor untuk indikator-indikator dalam subset. Penghitungan ini dapat dilakukan dengan mudah menggunakan program SPSS, yaitu suatu program yang sering digunakan untuk analisis data statistik, pengelolaan data, dan penyimpanan data (database). 
Tabel 1.1. Contoh skor untuk variabel, fulset dan subset

\begin{tabular}{|c|c|c|c|c|c|c|c|c|c|c|}
\hline Rsp & V1 & V2 & V3 & V4 & V5 & V... & Full & V123 & V124 & V125 \\
\hline A & 1 & 1 & 3 & 2 & 1 & $\ldots$ & 17 & 5 & 4 & 3 \\
\hline B & 2 & 3 & 3 & 2 & 2 & $\ldots$ & 20 & 8 & 7 & 7 \\
\hline C & 1 & 1 & 2 & 1 & 2 & $\ldots$ & 18 & 4 & 3 & 4 \\
\hline D & 2 & 3 & 3 & 2 & 3 & $\ldots$ & 22 & 8 & 7 & 8 \\
\hline
\end{tabular}

Tabel 1.1 adalah contoh yang dapat dihitung dengan cepat menggunakan SPSS. Pada tabel ini, jumlah responden (Rsp) hanya empat, jumlah subset hanya tiga (dari total 84 subset). Variabel V123 berarti subset kombinasi dari V1, V2 dan V3.

Langkah selanjutnya adalah menghitung korelasi antara subset dan fulset. Penghitungan ini mudah dilakukan dengan SPSS. Subset yang dipilih adalah yang memiliki koefisien korelasi tertinggi dengan fulset. Ini berarti, indikator dalam subset adalah indikator yang dipilih untuk daftar indikator final (daftar pendek).

Hasil penghitungan SPSS-nya kurang lebih seperti berikut:

\begin{tabular}{|l|l|l|l|l|l|}
\hline & & "Full" & V123 & V124 & V125 \\
\hline "Full" & $\begin{array}{l}\text { Correlation } \\
\text { Coefficient }\end{array}$ & 1.000 & $0.876^{*}$ & $0.775^{*}$ & $0.570^{*}$ \\
\hline
\end{tabular}

Hasil ini sekedar ilustrasi, angka-angka tidak dihitung dari Tabel 1.1. Contoh ini menunjukkan bahwa V123 memiliki koefisien korelasi paling tinggi, yang berarti bahwa indikator V1, V2 dan V3 dapat mewakili seluruh indikator fulset. Dengan demikian $\mathrm{V} 1, \mathrm{~V} 2$ dan V3 terpilih menjadi indikator.

\section{Survei Uji Coba Kedua}

Survei uji coba kedua dilakukan untuk menganalisis sekali lagi apakah indikator yang dipilih benar-benar merupakan indikator yang paling cocok. Kita dapat menggunakan metode yang sama dengan sebelumnya (lihat 'Penilaian Calon Indikator' di atas). Jika informasi dari uji coba ini dapat diterima oleh pihak-pihak yang memahami daerah (termasuk Tim Pemantau), maka indikator ini dapat digunakan sebagai indikator resmi.

Selain menganalisis indikator, uji coba kedua juga dilakukan untuk memeriksa aspek-aspek survei lainnya, misalnya:

- Kualitas lembar wawancara

- Apakah bahasanya mudah dipahami?

- Apakah penjelasannya cukup lengkap?

- Apakah kualitas cetaknya bagus?

- Apakah ukuran huruf dan tata letaknya sudah tepat?

- Pemilihan petugas survei

- Logistik (keperluan selama survei)

- Distribusi logistik

- Mekanisme pelatihan untuk petugas pendata

- Administrasi dan prosedur keuangan

- Waktu survei (dalam satu tahun) yang dipilih

- Persiapan sebelum survei sebenarnya (untuk menghindari keengganan responden untuk bekerja sama)

- Produktivitas (berapa banyak wawancara yang dapat diselesaikan per hari oleh satu petugas survei). 
Perekrutan Pendata Desa 


\section{Perekrutan Pendata Desa}

Perekrutan pendata desa merupakan kegiatan lapangan pertama yang dilakukan oleh petugas kecamatan. Kegiatan ini merupakan tanggungjawab petugas kecamatan masingmasing sebagai salah satu persiapan untuk pelatihan pendata desa.

Perekrutan harus dilakukan dengan cara bertemu langsung dengan calon pendata di desanya masing-masing. Oleh karena itu, petugas kecamatan harus mengunjungi desadesa dengan menggunakan dana transportasi yang telah disediakan.

Ada enam langkah yang harus dilaksanakan dalam perekrutan pendata desa, yaitu: (1) memeriksa bahan-bahan sebelum berangkat ke lapangan; (2) menemui kepala desa, mencari calon pendata desa; (3) menemui calon pendata desa; (4) menjelaskan cara pembuatan sketsa pemukiman; (5) menyampaikan undangan dan kerangka acuan; dan (6) mencatat identitas pendata desa.

\section{Langkah 1: Memeriksa Bahan-bahan Sebelum Berangkat ke Lapangan}

Persiapkan bahan-bahan yang harus dibawa dalam perjalanan untuk merekrut dan mengundang pendata desa. Perjalanan harus dilakukan paling cepat tiga hari sebelum pelatihan dilakukan dan jangan dibuat terlalu dekat dengan pelatihan karena pendata desa perlu waktu untuk membuat sketsa perumahan. Bahan-bahan yang harus dibawa dalam perjalanan adalah:
1. Tiga lembar kertas $A 3$ per desa

2. Pensil dan penghapus, masing-masing sebuah per pendata

3. Map plastik masing-masing satu buah per pendata desa

4. Surat undangan dari kecamatan untuk mengikuti pelatihan pendata desa yang ditujukan bagi pendata desa (nama dikosongkan dulu)

5. Fotokopi materi "Pemilihan Responden" (Modul 3) untuk dibagikan, satu eksemplar per pendata desa

6. Biaya transportasi untuk petugas kecamatan yang berkeliling ke desa-desa (bukan untuk pendata desa)

7. Kartu tanda pengenal pendata (dikosongkan dulu).

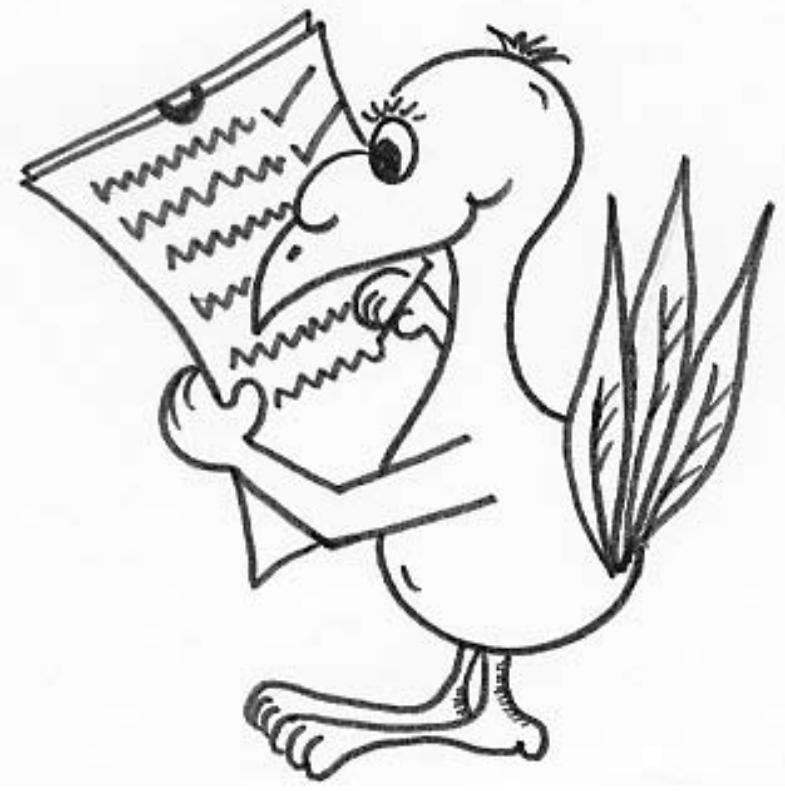

\section{Langkah 2: Menemui Kepala Desa, Mencari Calon Pendata}

Setelah tiba di desa yang dituju, temui kepala atau pengurus desa lainnya dan jelaskan tujuan kegiatan pemantauan kemiskinan ini (tujuan dapat dilihat dalam Konsep 
Pemantauan). Beritahukan kepada kepala atau pengurus desa bahwa Anda akan merekrut pendata desa. Jelaskan syaratsyarat untuk menjadi pendata desa. Tanyakan pada kepala atau pengurus desa apakah mereka memiliki usulan nama orang yang memenuhi kriteria tersebut.

Kriteria untuk menjadi pendata desa adalah:

a. Bersedia menjadi pendata desa setelah mengetahui hak dan kewajibannya

b. Dapat baca tulis

c. Dapat berbahasa Indonesia dengan lancar

d. Berpendidikan minimal SLTA

e. Tidak turut dalam kepengurusan desa, terutama pada pemerintah desa sebagai kepala desa, sekretaris desa, dan akan lebih baik juga bila tidak menjadi pengurus badan perwakilan desa (BPD), lembaga adat maupun lembaga pemberdayaan masyarakat (LPM)

f. Memiliki perilaku yang baik, misalnya: selalu bertanggung jawab pada pekerjaannya dan dikenal jujur

g. Diutamakan guru (yang tidak menjadi pengurus desa)

Seperti telah dijelaskan pada bab Konsep Pemantauan, pendata desa diutamakan dari para guru yang ada di desa bersangkutan, dengan alasan:

- Tingkat pemahaman dan wawasan

- Kemampuan komunikasi

- Netralitas dalam masyarakat.

Jika tidak ada guru yang tinggal di desa yang bersangkutan, Anda dapat merekrut masyarakat biasa asalkan memenuhi syarat (a) sampai dengan syarat (f).

\section{Langkah 3: Menemui Calon Pendata Desa}

Temui calon pendata desa yang diusulkan oleh kepala desa. Jelaskan kepadanya tugas dan kewajiban serta hak pendata desa.

\section{Tugas dan Kewajiban Pendata Desa}

Pendata desa memiliki tugas dan kewajiban sebagai berikut:

1. Membuat sketsa pemukiman lengkap dengan nama kepala rumah tangga untuk setiap rumah yang ada di desa (kertas gambar disediakan dan diantar langsung oleh petugas kecamatan)

2. Mengikuti pelatihan di kecamatan selama dua hari efektif

3. Membuat rencana wawancara (pemilihan responden dan pengisian formulirnya)

4. Melakukan wawancara rumah tangga sesuai perencanaan yang dilakukan pada pelatihan

5. Menyerahkan hasil wawancara, formulir pemilihan responden dan sketsa pemukiman kepada petugas pemeriksa.

\section{Hak-hak Pendata Desa}

1. Mendapatkan honor wawancara (misalnya: Rp.6.000,- ) per lembar wawancara yang diselesaikan dengan baik

2. Mendapatkan fasilitas selama pelatihan, misalnya: uang saku, konsumsi, penginapan, biaya transportasi

3. Mendapatkan penggantian transportasi untuk mengantarkan lembar wawancara yang telah terisi. Jika pendata desa lebih dari satu orang per desa, maka biaya transportasi mengantar hanya disediakan untuk satu orang.

Honor untuk wawancara akan dibayarkan setelah hasil wawancara diserahkan ke petugas pemeriksa. Petugas pemeriksa akan memotong honor jika pendata desa tidak memenuhi standar kerja yang telah dijelaskan pada saat pelatihan. Perlu diketahui bahwa Tim Pemantau akan melakukan pemeriksaan lapangan setelah pendataan (wawancara) selesai dilakukan. 
Setelah calon pendata desa mengetahui hak dan kewajibannya, langkah selanjutnya adalah menanyakan kesediaannya untuk menjadi pendata desa Jika bersedia, minta kepadanya untuk membuat sketsa pemukiman dan menghitung jumlah rumah yang ada di desa. Tentunya perlu dijelaskan terlebih dahulu tentang bagaimana cara membuat sketsa pemukiman (lihat Langkah 4).

Jika calon tersebut tidak bersedia, temui calon lainnya, jelaskan tugas, hak, dan kewajiban pendata desa, dan tanyakan kesediaannya. Lakukan terus hal ini sampai mendapat orang yang bersedia menjadi pendata.

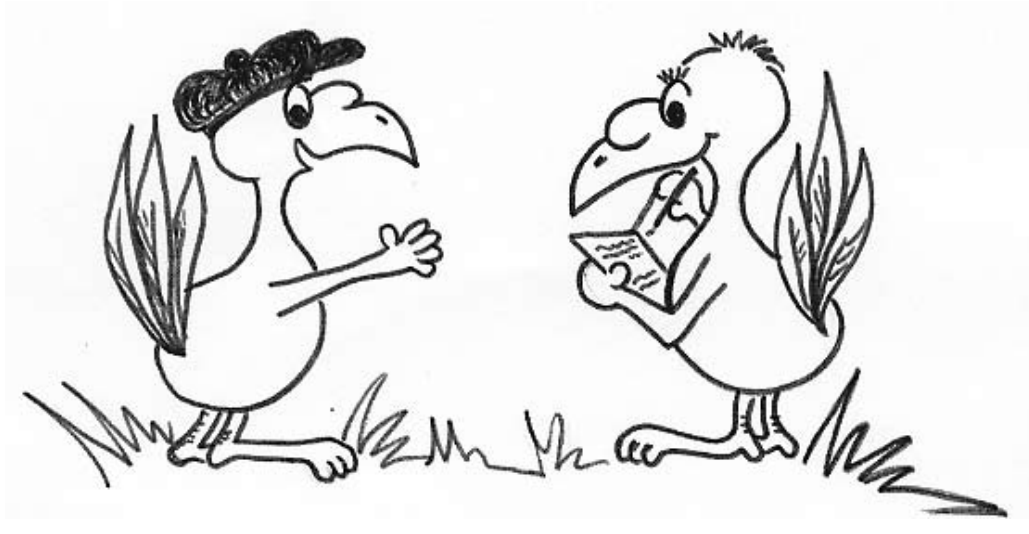

\section{Pendata Cadangan}

Untuk antisipasi adanya pendata desa yang tiba-tiba tidak dapat mengikuti pelatihan (misalnya karena sakit), perlu ada satu orang pendata cadangan yang direkrut. Pendata cadangan harus diketahui oleh pendata terpilih dan kepala desa agar keduanya dapat sewaktu-waktu memberitahukan kepada yang bersangkutan ketika pendata terpilih tidak dapat menjalankan tugasnya.

\section{Langkah 4: Menjelaskan Cara Pembuatan Sketsa Pemukiman}

Setelah mendapatkan pendata desa, langkah selanjutnya adalah menjelaskan kepadanya cara membuat sketsa pemukiman desa. Berikan Modul 3 kepada pendata desa terpilih, ingatkan bahwa dia harus membawanya kembali ke pelatihan lengkap bersama sketsa pemukiman.

\section{Langkah-langkah dalam menyiapkan sketsa pemukiman:}

- Ambillah kertas gambar ukuran A3 yang sudah disediakan. Pendata desa akan diberi tiga lembar kertas gambar, dua di antaranya digunakan untuk cadangan bila ada kesalahan. Artinya, pendata desa hanya perlu membuat satu gambar saja.

- Mulailah menggambar garis yang dapat membantu memberikan arah dalam menggambar pemukiman, misalnya garis sungai dan/atau garis jalan.

- Lalu mulailah menggambar posisi rumah, setiap satu rumah diwakili satu kotak. Bangunan-bangunan lain yang bukan rumah dapat diberi tanda lain yaitu segitiga dengan tulisan penjelasan nama bangunan (misalnya: kantor kepala desa). Satu rumah dihitung sebagai satu rumah tangga. Rumah yang tidak berpenghuni juga diberi tanda segitiga.

- Berilah nomor urut (1, 2, 3, dst.) pada setiap kotak (rumah berpenghuni) sampai seluruh kotak memiliki nomor. Penomoran harus mengalir dengan logis: nomor berikutnya diberikan pada rumah yang paling dekat dan bersebelahan (bukan yang berseberangan sungai atau jalan). Misalnya rumah nomor 2 harus berada di sebelah rumah nomor 1.

- Bangunan yang bukan rumah (bertanda segitiga) tidak perlu diberi nomor urut. 
- Nomor kotak terakhir menunjukkan jumlah rumah tangga yang ada di desa tersebut. Tulislah jumlah rumah tangga yang ada di desa pada pojok kiri atas lembar kertas gambar.

\section{Berikut adalah beberapa catatan penting dalam pembuatan peta sketsa pemukiman:}

- Bila di sebuah desa terdapat lebih dari satu dusun, maka peta sketsa harus dibuat untuk setiap dusun. Setelah itu, berikan nomor rumah tangga dengan cara mengurutkannya, termasuk untuk yang berada di dusun yang berbeda (disambung). Nomor pertama pada dusun kedua adalah terusan dari nomor terakhir pada dusun pertama.

- Bangunan yang bukan rumah tinggal (misalnya gereja, posyandu, masjid, dll.) tidak perlu diberi nomor, tetapi tetap perlu digambar.

- Khusus untuk lamin (rumah panjang), setiap kamar pada lamin dianggap seperti satu rumah tangga. Hal yang sama juga dilakukan untuk kasus rumah bangsalan.
- Rumah rakit (yang sering berpindah-pindah) harus ditandai pada posisi dimana rumah tersebut berada saat data dikumpulkan.

\section{Langkah 5: Sampaikan Undangan dan Kerangka Acuan}

Sampaikan undangan dan kerangka acuan kepada pendata desa terpilih. Undangan dan kerangka acuan penting untuk disampaikan agar pendata desa dapat benar-benar mempelajari tugas yang akan dia jalankan.

\section{Langkah 6: Mencatat Identitas Para Pendata Desa}

Catat nama pendata desa terpilih, nama desanya, pekerjaan, dan nomor KTP-nya. Data ini akan digunakan untuk pembuatan kontrak kerja dengan pemerintah daerah. 

Pemilihan Responden 


\section{Pemilihan Responden}

Responden adalah orang yang diwawancara yang memberikan informasi atau data pada pendata desa. Dalam pendataan ini hanya ada satu jenis responden, yaitu responden rumah tangga. Karena terbatasnya dana dan sumber daya, pendataan dilakukan secara sampel. Oleh karena itu perlu dilakukan pemilihan responden yang tidak mengandung bias.

Pemilihan bias adalah pemilihan yang terarah pada sesuatu kecenderungan, baik dilakukan secara sengaja maupun tidak. Pemilihan bias dapat terjadi misalnya karena pendata, baik atas keinginan sendiri ataupun karena diminta orang lain, mengarahkan pemilihan responden pada rumah tangga miskin dengan tujuan agar desanya mendapatkan banyak bantuan.

Dengan sistem pemantauan seperti dijelaskan pada panduan ini, ada banyak cara mengetahui pemilihan bias. Ketika hal ini diketahui, maka seluruh data desa tersebut akan dibatalkan sehingga desa tersebut akan sangat sulit mendapatkan bantuan.

Pemilihan responden dilakukan oleh pendata desa pada saat pelatihan dengan pengawasan langsung oleh pelatih. Walaupun demikian, jika terjadi penggantian responden, maka hal tersebut harus dilakukan pendata sendiri dengan mengacu pada ketentuan yang ada.

Empat langkah dalam pemilihan responden adalah: (1) Membuat peta sketsa pemukiman; (2) Memilih responden; (3) Mengganti responden terpilih (hanya jika perlu); (4) Mengisi Form-A, dan (5) Memeriksa pemilihan responden.

\section{Langkah 1: Menyiapkan Peta Sketsa Perumahan}

Sebelum berangkat ke pelatihan di kecamatan, pendata desa harus membuat peta sketsa pemukiman terlebih dahulu seperti yang diajarkan oleh petugas kecamatan. Langkahlangkah dalam pembuatan sketsa pemukiman adalah sebagai berikut:

- Ambillah kertas gambar ukuran A3 yang sudah disediakan. Pendata desa akan diberi tiga lembar kertas gambar, dua di antaranya digunakan untuk cadangan bila ada kesalahan. Artinya, pendata desa hanya perlu membuat satu gambar saja.

- Mulailah menggambar garis yang dapat membantu memberikan arah dalam menggambar pemukiman, misalnya garis sungai dan atau garis jalan.

- Lalu mulailah menggambar posisi rumah, setiap satu rumah diwakili satu kotak. Bangunan-bangunan lain yang bukan rumah dapat diberi tanda lain yaitu segitiga dengan tulisan penjelasan nama bangunan (misalnya: kantor kepala desa). Satu rumah dihitung sebagai satu rumah tangga. Rumah yang tidak berpenghuni juga diberi tanda segitiga.

- Berikanlah nomor urut (1, 2, 3, dst.) pada setiap kotak (rumah berpenghuni) sampai seluruh kotak memiliki nomor. Penomoran harus mengalir dengan logis: nomor berikutnya diberikan pada rumah yang paling dekat dan bersebelahan (bukan yang berseberangan sungai atau jalan). Misalnya rumah nomor 2 harus berada di sebelah rumah nomor 1.

- Bangunan yang bukan rumah (bertanda segitiga) tidak perlu diberi nomor urut.

- Nomor kotak terakhir menunjukkan jumlah rumah tangga yang ada di desa tersebut. Tulislah jumlah rumah tangga yang ada di desa pada pojok kiri atas lembar kertas gambar.

Berikut adalah beberapa catatan penting dalam pembuatan peta sketsa pemukiman: 
- Bila di sebuah desa terdapat lebih dari satu dusun, maka peta sketsa harus dibuat untuk setiap dusun. Setelah itu, berikan nomor rumah tangga dengan cara mengurutkannya termasuk untuk yang berada di dusun yang berbeda (disambung). Nomor pertama pada dusun kedua adalah terusan dari nomor terakhir pada dusun pertama (lihat contoh pada Gambar 3.1).

- Bangunan yang bukan rumah tinggal (misalnya gereja, posyandu, masjid, dll.) tidak perlu diberi nomor, tetapi tetap perlu digambar.

- Khusus untuk lamin (rumah panjang), setiap kamar pada lamin dianggap seperti satu rumah tangga (lihat contoh pada Gambar 3.1). Hal yang sama juga harus dilakukan untuk kasus rumah pemondokan.

- Rumah rakit (yang sering berpindah-pindah) harus ditandai pada posisi dimana rumah tersebut berada saat data dikumpulkan.

\section{Langkah 2: Memilih Responden}

Responden rumah tangga berjumlah minimal 20 rumah tangga atau sekitar 33-35 persen dari jumlah rumah tangga yang ada di desa. Cara pemilihan responden rumah tangga adalah sebagai berikut:

- Jika jumlah rumah tangga di suatu desa kurang atau sama dengan 20, maka seluruhnya harus ditanya dan berarti harus dilakukan sensus.

- Jika jumlah rumah tangga di suatu desa lebih dari 20 tetapi kurang dari 61 rumah tangga, maka jumlah responden adalah 20 rumah tangga. Nomor rumah tangga dipilih dengan cara undian. Cara undian dapat dilakukan dengan mudah yaitu dengan menuliskan seluruh nomor rumah tangga yang ada pada potongan kertas kecil. Dengan demikian, jika ada 51 rumah tangga maka ada 51 potongan kertas yang sudah diberi nomor rumah tangga. Kemudian gulung atau lipat seluruh potongan kertas tersebut sehingga tulisannya tidak terlihat. Masukkan ke dalam mangkuk atau wadah apa saja lalu diacak.
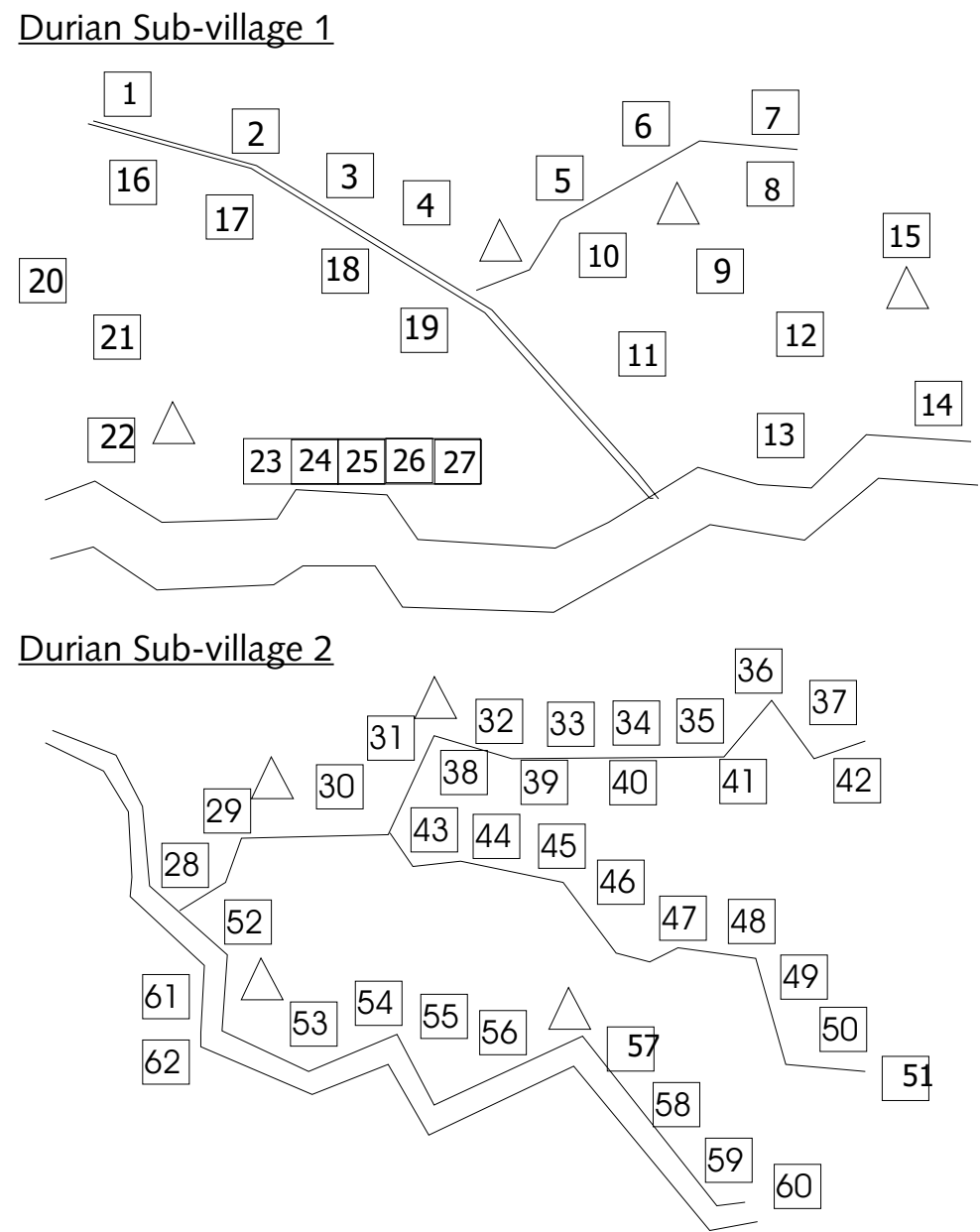

Gambar 3.1. Contoh Sketsa Desa Durian

Catatan: Desa durian memiliki dua dusun, dusun pertama sampai dengan nomor 27, dilanjutkan dengan nomor 28 di dusun kedua. Ada beberapa tanda segitiga yang berarti bukan rumah tempat tinggal berpenghuni. Rumah nomor 23 sampai dengan nomor 27 adalah rumah panjang (lamin) 
Kemudian ambil 20 gulungan atau lipatan kertas tadi, sehingga yang tersisa di dalam wadah tinggal 31 saja. Kedua puluh kertas yang diambil tadi adalah nomor rumah tangga yang terpilih dan harus dikunjungi.

- Jika jumlah rumah tangga di suatu desa adalah 61 atau lebih maka pemilihan dilakukan dengan cara loncat dua, dimulai dari rumah nomor 1 sampai rumah terakhir.

Contoh 1: Jumlah rumah tangga di Desa Durian (Gambar 3.1) adalah 62 rumah tangga, maka rumah tangga yang dipilih adalah nomor:

$1,4,7,10,13,16,19,22,25,28,31,34,37,40,43$, $46,49,52,55,58$, dan 61 .

Dengan demikian jumlah sampel adalah 21 rumah tangga atau sekitar 34 persen dari jumlah total rumah tangga.

Contoh 2: Jika jumlah rumah tangga di Desa Durian sebanyak 94 rumah tangga, maka nomor rumah tangga yang dipilih adalah:

$1,4,7,10,13,16,19,22,25,28,31,34,37,40,43$, $46,49,52,55,58,61,64,67,70,73,76,79,82,85$, 88,91 , dan 94 .

Dengan demikian jumlah sampel adalah 32 rumah tangga atau sekitar 34 persen dari jumlah total rumah tangga.

Beberapa pertimbangan penting dalam memilih responden:

1. Pemukiman dalam barak (kamp) perusahaan tidak disertakan, karena rumah tangga yang tinggal di kamp perusahaan sangat tergantung pada perusahaannya, dan karena itu tidak sesuai dengan asumsi pada lembar wawancara. Selain itu, pemerintah daerah kurang berperan dalam membantu mereka.
2. Kompleks atau rumah lokalisasi (prostitusi) tidak bisa dipilih sebagai responden, karena model kehidupannya berbeda dengan asumsi yang ada pada lembar wawancara. Juga karena mereka sering tidak tinggal permanen dalam satu tahunnya.

\section{Durian Sub-village 1}
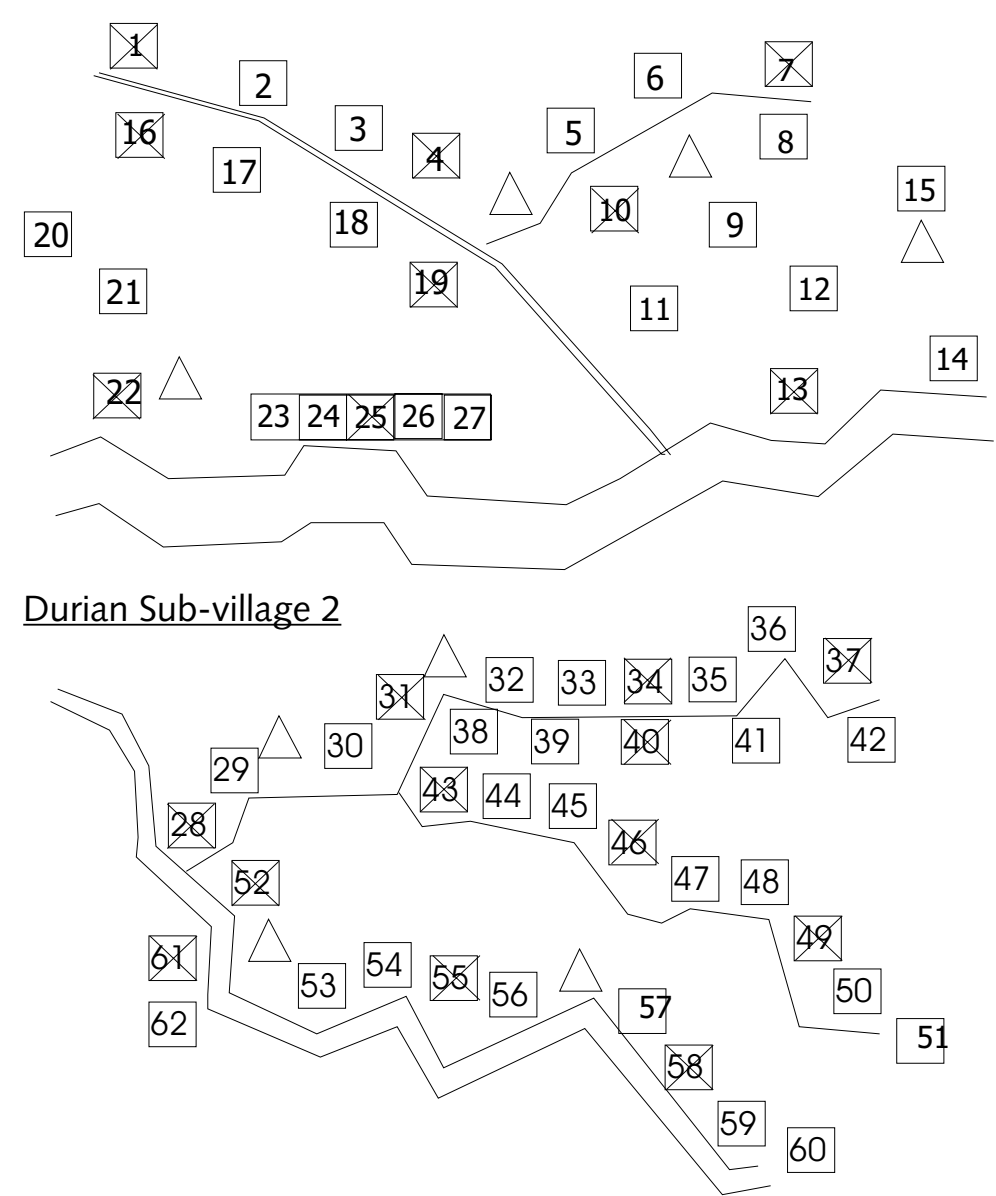

Gambar 3.2. Contoh pemilihan responden 
3. Asrama pelajar tidak bisa dipilih, karena pada umumnya mereka masih tergantung pada rumah tangga orang tuanya.

4. Bangsalan yang dihuni oleh pegawai perusahaan tidak tetap (sering berpindah kurang dari satu tahun) tidak boleh dipilih, dan harus diberi tanda segitiga.

5. Rumah tangga yang memiliki lebih dari satu rumah di desa yang sama hanya boleh dipilih satu kali.

\section{Langkah 3: Mengganti Responden Terpilih (Hanya Bila Diperlukan)}

1. Desa dengan 20 rumah tangga atau kurang Jika ada rumah tangga yang kosong sampai dengan selesainya masa survei (25 hari sejak dimulai), maka rumah tangga tersebut dapat ditinggalkan. Dengan demikian jumlah responden hanyalah rumah tangga yang ada atau yang dapat diwawancarai sampai dengan selesainya waktu survei.

2. Desa dengan lebih dari 20 rumah tangga

Penggantian responden terpilih hanya dapat dilakukan pada rumah tangga yang tidak ada (kosong) selama 25 hari sejak dimulainya survei. Rumah yang kosong tersebut dapat diganti dengan cara undian, seperti dijelaskan di atas. Pendata desa menuliskan nomor rumah yang belum terpilih pada kertas, kertas tersebut digulung dan kemudian ditaruh pada sebuah wadah. Jumlah yang diambil harus sama dengan jumlah rumah yang kosong. Penggantian rumahtangga terpilih tidak boleh lebih dari 20 persen dari jumlah responden.

\section{Langkah 4: Mengisi Formulir A}

Formulir pemilihan rumah tangga responden, yang kemudian disebut sebagai "Form-A", bermanfaat untuk memastikan bahwa pendata desa melakukan penomoran dengan benar.
Formulir ini juga bermanfaat untuk memeriksa penggantian responden yang akan diketahui setelah pendataan selesai.

Formulir ini terdiri dari empat kolom yaitu: nomor urut, nomor lembar wawancara, nama kepala rumah tangga dan nama responden.

Nomor urut bermanfaat untuk mengidentifikasi responden mana yang diganti, yaitu dengan mencoretnya untuk kemudian dituliskan kembali (nomor urut yang sama) pada baris di bawah dengan mencantumkan rumah tangga responden yang baru yang berhasil diwawancarai (lihat contoh pada Tabel 3.1).

Nomor rumah tangga bermanfaat untuk memeriksa pemilihan responden. Selain itu, nomor ini juga dapat digunakan untuk memeriksa pemilihan rumah tangga miskin oleh pengurus desa.

Kepala rumah tangga adalah orang yang bertanggung jawab atas rumah tangga tersebut. Informasi ini bermanfaat untuk mengidentifikasi rumah tangga responden yang dimaksud. Sedangkan responden adalah anggota rumah tangga tersebut yang diwawancarai. Hal ini penting untuk diketahui agar jelas siapa sumber informasinya.

Di bagian bawah formulir terdapat dua keterangan yaitu jumlah responden dan jumlah responden maksimal yang boleh diganti.

Dalam formulir ini, nomor rumah tangga ditulis bersama dengan kode desa. Penulisan yang lengkap ini bertujuan agar seluruh rumah tangga di daerah memiliki nomor yang berbeda sehingga dapat mewakili data dan informasinya masing-masing (nomor identitas).

Nomor rumah tangga terdiri dari 10 (sepuluh) angka. Enam angka pertama adalah nomor (kode) desa yang daftarnya 
dapat dilihat pada Lampiran 3. Sedangkan empat angka terakhir adalah nomor rumah.

Tabel 3.1. Contoh formulir pemilihan rumah tangga responden (Form $A$ )

\begin{tabular}{|c|c|c|c|}
\hline No. & \begin{tabular}{|c|} 
Nomor Lembar \\
Wawancara/Nomor \\
Rumah Tangga
\end{tabular} & $\begin{array}{l}\text { Nama Kepala } \\
\text { Rumah Tangga }\end{array}$ & $\begin{array}{c}\text { Nama Responden } \\
\text { untuk } 2005\end{array}$ \\
\hline 1. & 1820020001 & Rusmin & Rusmin \\
\hline 2. & 1820020004 & Rohmi & Amat \\
\hline 3. & 1820020007 & Karto & Karto \\
\hline 4. & 1820020010 & Ayus & Ayus \\
\hline 5. & 1820020013 & Srani & Srani \\
\hline 6. & 1820020016 & Bambang & Bambang \\
\hline 7. & 1820020019 & Popot & Tinus \\
\hline 8. & 1820020022 & Romen & Romen \\
\hline 9. & 1820020025 & Kren & Kren \\
\hline 10. & 1820020028 & Suri & Suri \\
\hline 11. & 1820020031 & Đamiyati & \\
\hline 12. & 1820020034 & Minta & Ari \\
\hline 13. & 1820020037 & Sopian & Asdi \\
\hline 14. & 1820020040 & Bedu & Bedu \\
\hline 15. & 1820020043 & Rosid & Rosid \\
\hline 16. & 1820020046 & Kasmin & Kasmin \\
\hline 17. & 1820020049 & Hamid & \\
\hline 18. & 1820020052 & Anawar & Sardi \\
\hline 19. & 1820020055 & Riden & Riden \\
\hline 20. & 1820020058 & Santi & Santi \\
\hline 21. & 1820020061 & Martinus & Martinus \\
\hline 11. & 1820020015 & Ramin & Dino \\
\hline 17. & 1820020030 & Asro & Asro \\
\hline \multicolumn{3}{|c|}{ Jumlah total responden } & 21 \\
\hline \multicolumn{3}{|c|}{$\begin{array}{l}\text { Jumlah responden maksimal yang dapat } \\
\text { diganti }\end{array}$} & 4 \\
\hline
\end{tabular}

Contoh:

Rumah nomor 17 di Desa Apel, akan diberi nomor: 1820020017

Angka 182002 adalah kode desa Apel, sedangkan angka 0017 adalah nomor rumah. Nomor rumah harus terdiri dari empat angka sehingga jika nomor rumahnya di bawah 10, harus ditambah tiga angka nol di depannya. Jika nomor rumah terdiri dari dua angka (antara 10 sampai dengan 99) maka harus ditambah dua angka nol di depannya.

Nomor rumah tangga, jumlah responden, dan jumlah maksimal responden yang dapat diganti harus diisi selama pelatihan pendata desa dan diperiksa langsung oleh pelatih. Tentunya akan jauh lebih baik jika dalam pelatihan itu juga dapat ditulis nama kepala rumah tangga dengan lengkap, sedangkan nama responden baru dapat diisi setelah pendataan selesai.

Perhatikan Tabel 3.1, yaitu pada rumah tangga responden bernomor 11 dan 17. Kedua nomor tersebut dicoret karena tidak dapat diwawancarai dan diganti oleh dua rumah tangga yang lain. Pada tabel juga nampak bahwa nomor urut (pengganti) tidak berubah, tetapi nomor rumah tangga berubah. Nomor urut tidak diubah untuk mengetahui siapa diganti oleh siapa. Disini terlihat Damiyati (1820020031) diganti oleh Ramin (1820020015), sedangkan Hamid (1820020049) diganti Asro (1820020030). Nomor rumah tangga berubah karena respondennya memang diganti.

\section{Langkah 5: Memeriksa Pemilihan Responden}

1. Memeriksa penomoran rumah

Penomoran yang baik memiliki urutan nomor yang selalu ke arah yang bersebelahan. Penomoran yang salah adalah jika nomor berikutnya diberikan pada 
rumah di seberang sungai atau jalan. Mengurut dengan cara menyeberang hanya dibolehkan ketika rumah yang bersebelahan sudah selesai (habis) dinomori.

2. Memeriksa rumah terpilih, apakah ada yang bersebelahan

- Pada desa dengan lebih dari 60 rumah tangga, tidak mungkin ada rumah tangga responden yang rumahnya tepat bersebelahan, kecuali pada kasus pemukiman yang tidak beraturan (tidak membentuk garis atau keteraturan posisi) atau pada kasus penggantian responden (yang dipilih dengan diundi sehingga bisa jadi yang terpilih adalah rumah tangga tepat di sebelah rumah tangga responden lainnya). Persentase responden biasanya antara 32 persen sampai dengan 35 persen dari jumlah total rumah tangga.

- Untuk desa dengan jumlah rumah tangga antara 21 sampai dengan 60 yang menggunakan pemilihan secara lotre (arisan), undian, ada kemungkinan terpilih rumah responden yang bersebelahan. Jumlah responden yang bersebelahan tergantung pada jumlah rumah tangga yang ada.

- Untuk desa dengan rumah tangga berjumlah 20 atau kurang, seluruh rumah tangga terpilih bersebelahan karena pendataan dilakukan dengan cara sensus. 

Teknik Wawancara 


\section{Teknik Wawancara}

Wawancara merupakan tahap paling penting dalam pemantauan kemiskinan, karena kegiatan inilah yang menghasilkan data. Tugas ini merupakan tanggung jawab pendata desa.

\section{Syarat Responden}

Responden adalah orang yang diwawancara atau yang memberikan keterangan. Responden harus memenuhi syaratsyarat berikut:

1. Anggota rumah tangga terpilih, bukan tamu atau pengunjung

2. Sudah dewasa yaitu yang berusia minimal 17 tahun atau sudah menikah, anak-anak tidak boleh menjadi responden

3. Dalam keadaan normal (tidak cacat mental), dapat mendengar dan berbicara dengan baik.

\section{Perencanaan Wawancara}

Perencanaan wawancara perlu dilakukan untuk memastikan bahwa seluruh responden selesai diwawancarai sebelum habis batas waktunya. Dalam perencanaan perlu ditentukan siapa yang akan diwawancarai dan kapan.

\section{Tempat dan Suasana Wawancara}

Tempat terbaik untuk wawancara adalah di rumah responden sendiri. Hal ini penting untuk menghindari adanya pengaruh jawaban dari orang yang bukan anggota rumah tangga responden. Suasana wawancara harus dipastikan bebas dari orang lain yang bukan anggota rumah tangga responden. Untuk membuat wawancara lebih leluasa, lebih baik untuk membuat janji terlebih dahulu.

\section{Pengisian Lembar Wawancara}

1. Mulailah mengisi 10 angka nomor rumah tangga pada kotak di pojok kanan atas halaman pertama. Cara pengisian nomor rumah tangga dapat dilihat pada Modul 3.

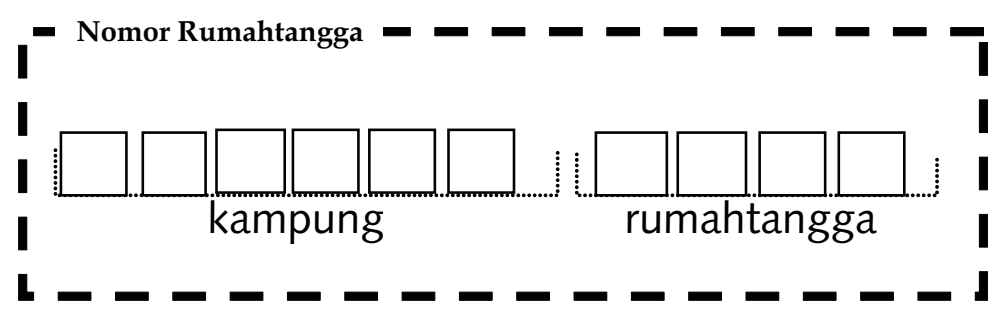

Gambar 4.1 Nomor Rumahtangga

2. Selanjutnya, isi kotak 'Keterangan Lembar Wawancara' (Gambar 4.2).

3. Perhatikan setiap perintah bantuan yang ada pada lembar wawancara, termasuk cara mengisi. Sebagian besar pertanyaan yang diberikan adalah pertanyaan tertutup dengan pilihan-pilihan jawaban. Jawaban dipilih dengan cara melingkari angka yang ada di sebelah kirinya, lalu menuliskan angka yang dilingkari tersebut pada kotak yang berada di sebelah kanan pertanyaan. Sedangkan untuk pertanyaan terbuka (Var $4 \mathrm{~s} / \mathrm{d}$ Var 9) cukup menuliskan jawaban pada kotak di sebelah kanan yang sudah tersedia. 


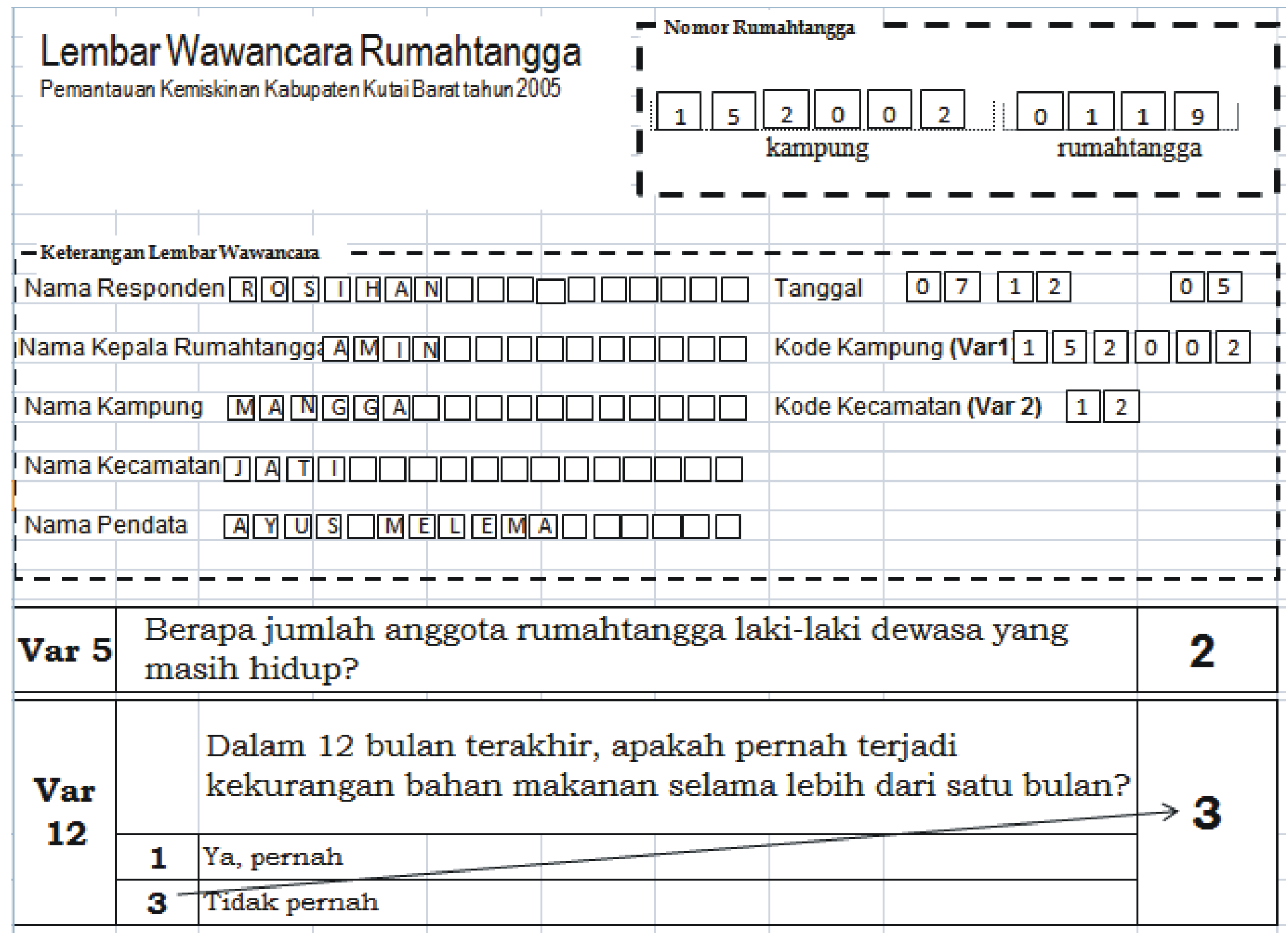

Gambar 4.2 Keterangan Lembar Wawancara 
4. Seluruh pertanyaan harus ada jawabannya. Tidak boleh ada satu pun pertanyaan yang dikosongkan (kecuali Var 27 ,yaitu saat responden mungkin memiliki kurang dari tiga sumber penghasilan).

5. Kotak di sebelah kanan harus diisi dengan angka, tidak boleh dengan huruf atau tanda baca. Jika jawabannya tidak ada, maka harus diisi 0 (nol), bukan dengan tanda strip (-).

\section{Tip dalam Melakukan Wawancara}

\section{Sebelum Wawancara}

1. Periksa perlengkapan wawancara.

2. Jangan membawa apapun kecuali materi-materi yang dibutuhkan untuk wawancara, jangan membawa barang-barang yang menarik perhatian responden yang berlebihan (misalnya: kamera model terbaru yang canggih).

3. Jangan melakukan wawancara ketika merasa letih, frustrasi, atau terganggu.

4. Lakukan pengamatan calon responden, pastikan wawancara dilakukan pada saat yang tepat.

5. Buatlah janji untuk memilih waktu yang tepat bagi responden dan pewawancara.

6. Persiapkan penampilan yang wajar, segar, dan bersih.

7. Isilah kode desa pada seluruh lembar wawancara.

8. Matikan telepon genggam, atau atur ke mode diam.

\section{Saat Memulai Wawancara}

1. Pastikan pada saat wawancara tidak ada orang dari rumah tangga lain yang berada di sekitar lokasi wawancara. Responden hanya boleh dipengaruhi oleh anggota rumah tangganya sendiri. Di luar anggota rumah tangga, walaupun keluarga dekat, tidak boleh mempengaruhi jawaban responden.
2. Perkenalkan diri serta maksud dan tujuan, termasuk peran Anda sebagai pewawancara (pendata desa).

3. Tanyakan apakah dia bersedia untuk diwawancara, jika tidak bersedia, tinggalkan responden tersebut dan lanjutkan dengan responden lainnya.

4. Bina hubungan secepat mungkin dengan pihak yang diwawancarai (ketahui siapa mereka dan bersikap akrab)

5. Perhatikan kebersihan diri Anda sendiri agar responden merasa nyaman.

\section{Selama Wawancara}

1. Bersikaplah sopan, ramah, dan sabar.

2. Bersikaplah sabar, utamakan kepentingan responden, jangan paksakan wawancara ketika responden tidak bisa berkonsentrasi.

3. Responden harus membaca lembar wawancara. Bila responden tidak paham, bantu dengan menjelaskan, ulangi pertanyaan jika perlu dengan pilihan kata yang mudah dipahami.

4. Jangan biarkan responden mengisi sendiri lembar wawancaranya.

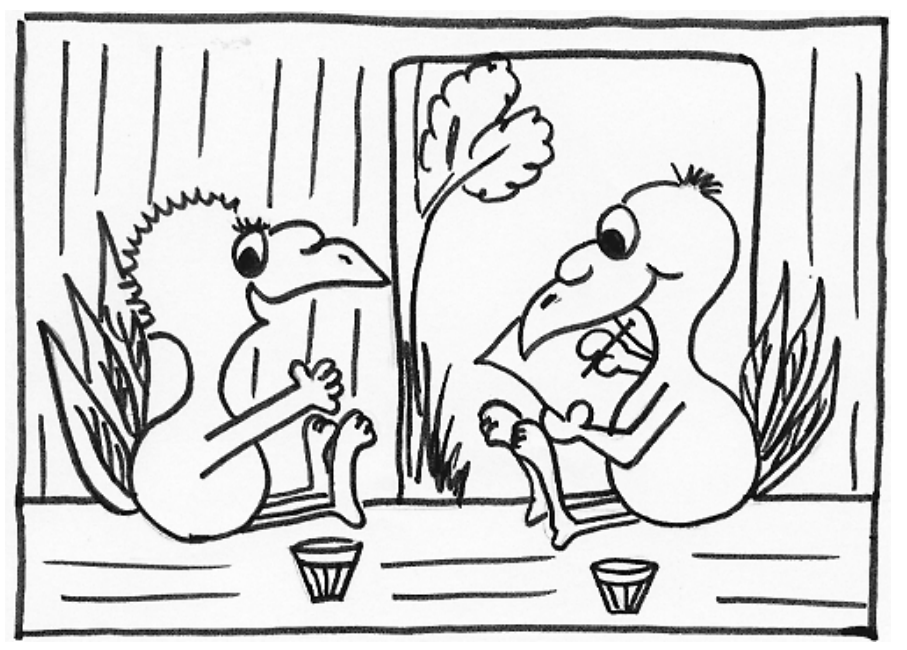


5. Gunakan bahasa yang mudah dimengerti. Jika Anda menggunakan bahasa setempat (bukan bahasa Indonesia), hati-hati dengan terjemahannya.

6. Jangan memberikan jawaban atau mengarahkan jawaban untuk responden.

7. Mulailah dari rasa tidak tahu, perasaan "sudah tahu" akan membuat Anda mengarahkan jawaban responden, atau bahkan memancing perdebatan.

8. Hindari perdebatan dengan orang yang diwawancarai dalam bentuk apa pun.

9. Pikirkan wawancara dari sudut pandang responden.

10. Buat pihak yang diwawancarai merasa nyaman, aman, dan tenang.

11. Perlihatkan minat terhadap orang yang diwawancarai. Hargai dan hormati seluruh jawaban responden, walaupun jawaban tersebut tidak sesuai dengan keinginan Anda.

12. Beri waktu kepada orang yang diwawancarai tersebut untuk berpikir, kemudian dengarkan dengan penuh perhatian apa yang dikatakannya.

13. Jangan terburu-buru untuk beralih ke pertanyaan berikutnya.

14. Perhatikan kerisauan yang dikemukakan responden, bersikaplah sensitif.

15. Formal versus informal:

a. Selipkan diskusi tentang hal-hal lain di antara pertanyaan wawancara

b. Selingi dengan makanan kecil yang Anda bawa

c. Selipkan humor dan canda.

17. Bagaimana Anda dapat memastikan responden menjawab dengan jujur?

a. Mintalah responden untuk jujur

b. Mulailah dengan diskusi informal

c. Bersikaplah seakrab mungkin.

18. Jika responden menjawab terlalu panjang lebar dan tidak ada hubungan dengan pertanyaan, potonglah pembicaraannya pada saat yang tepat, seperti saat dia menarik napas. Berlakulah sopan saat menyela, bersikaplah sensitif dan bijak.

19. Untuk menghormatinya, rangkum pembicaraannya, lalu tarik kembali responden ke pada pertanyaan Anda.

21. Abaikan hal-hal lain, berfokuslah pada wawancara.

\section{Di Akhir Wawancara}

1. Akhiri wawancara dengan menanyakan apakah ada hal yang dia ingin ketahui dari kegiatan pemantauan.

2. Pastikan Anda telah menulis tanggal, nama responden, nama desa, nama kecamatan, nama pendata (nama Anda) pada halaman pertama lembar kuesioner.

3. Pastikan seluruh pertanyaan telah terjawab.

4. Mintalah maaf kalau ada kesalahan.

5. Ucapkan terima kasih.

\section{Penting!}

Lembar wawancara ini dirancang sedemikian sehingga tidak ada kotak jawaban yang kosong. Jawaban kosong akan menyebabkan kesalahan penilaian dan analisis jawaban responden. Kesalahannya dapat berakibat fatal. Rumah tangga sejahtera dapat dianggap miskin dan sebaliknya. Jawaban kosong dalam jumlah banyak dapat membuat suatu desa tidak memiliki data kemiskinan. Tiadanya data kemiskinan akan membuat desa tersebut sulit untuk dibantu.

Segala bentuk manipulasi data atau tindakan yang bertujuan mengarah hasil pendataan pada suatu kesimpulan tertentu akan dengan mudah terlihat pada hasil analisis.

Demi kelancaran pendataan dan kesuksesan dalam upaya penanggulangan kemiskinan, merupakan hal yang sangat penting dijaga adalah bahwa pendata desa menjalankan tugasnya sesuai ketentuan ini. 

Indikator dan Lembar Wawancara 


\section{Indikator dan Lembar Wawancara}

Lembar wawancara adalah lembaran yang harus digunakan dan dibacakan sebagai dasar untuk melakukan wawancara.

\section{Lembar Wawancara}

Informasi pada lembar wawancara diawali dengan nomor rumah tangga yang berada pada pojok kanan atas di halaman muka. Penjelasan mengenai cara mengisi nomor rumah tangga dapat dilihat di Modul 3. Informasi lain dalam lembar wawancara adalah: nama responden, nama kepala rumah tangga, nama desa, nama kecamatan, nama pendata, serta tanggal wawancara. Responden adalah orang yang memberikan jawaban atas pertanyaan pada lembar wawancara. Jika pada saat wawancara ada beberapa orang dari anggota rumah tangga yang sedang berkumpul, cukup tulis nama salah seorang yang paling dituakan. Penulisan harus mengikuti kotak yang telah tersedia, satu huruf satu kotak. Pembuatan kotak tersebut dimaksudkan agar pendata desa menggunakan huruf cetak, bukan huruf sambung, sehingga mudah dibaca.

Untuk daerah yang kondisi masyarakat dan lingkungannya seperti di Kutai Barat, daftar indikator ini dapat

dipertimbangkan untuk digunakan. Tetapi untuk daerah yang memiliki kondisi berbeda, harus dilakukan pencarian indikator terlebih dahulu agar benar-benar dapat menggambarkan kondisi lokal.

\section{(VAR 1) Kode desa}

Adalah barisan nomor sebanyak enam angka yang sesuai dengan sistem penomoran kartu tanda penduduk. Kode desa mengacu pada SK atau peraturan kepala daerah. Kode desa yang digunakan pada dataset contoh sebagai kelengkapan panduan ini dapat dilihat pada Lampiran 3.

(VAR 2) Kode kecamatan

Dua angka pertama pada kode desa adalah kode kecamatan.

\section{Data Dasar Rumah Tangga}

(VAR 3) Jumlah anggota rumah tangga Anggota rumah tangga adalah seluruh orang yang biasanya bertempat tinggal di suatu rumah atau masih dalam tanggungan rumah tangga tersebut.

(VAR 4) Jumlah keluarga dalam rumah tangga Keluarga adalah kelompok orang karena ikatan pernikahan, termasuk pasangan yang sudah berpisah baik karena bercerai atau karena pasangannya meninggal dunia (duda atau janda), dengan atau tanpa anak-anak.

(VAR 5) Jumlah laki-laki dewasa dalam rumah tangga Anggota rumah tangga dewasa adalah yang sudah berumur 17 tahun atau lebih atau sudah berkeluarga atau sudah memiliki pekerjaan sendiri, dan masih tinggal di rumah tersebut. Jika tidak ada, harus ditulis nol (0), bukan tanda strip (-) atau dikosongkan.

(VAR 6) Jumlah perempuan dewasa dalam rumah tangga

Lihat VAR 5. 
(VAR 7)

\section{Jumlah anak laki-laki}

Anggota rumah tangga anak-anak adalah anggota rumah tangga yang berusia di bawah 17 tahun, belum menikah, dan masih dalam tanggungan rumah tangga tersebut walaupun mungkin anak-anak tidak tinggal di rumah tangga tersebut (misalnya karena alasan sekolah). Jika tidak ada, harus ditulis angka nol (0), bukan tanda strip (-) atau dikosongkan.

\section{(VAR 8) Jumlah anak perempuan} Lihat VAR 7.

\section{(VAR 9)}

\section{Suku mayoritas}

Adalah suku terbanyak yang ada dalam rumah tangga tersebut. Jika jumlahnya berimbang, cukup pilih suku dari kepala rumah tangga.

(VAR 10) Yatim piatu, janda, atau orang/anak catat Anak yatim piatu adalah anak-anak yang sudah tidak memiliki kedua orang tua. Janda adalah perempuan yang pernah menikah tetapi saat ini sudah tidak memiliki suami lagi. Penyandang cacat adalah setiap orang yang mempunyai kelainan fisik dan/atau mental, yang dapat mengganggu atau merupakan rintangan baginya untuk melakukan sesuatu secara normal. Penyandang cacat terdiri dari penyandang cacat fisik (misalnya: tidak dapat bicara, tidak dapat berjalan, dll) dan penyandang cacat mental (idiot, gila, dII).

\section{Kesejahteraan subjektif}

Mengingat perasaan subyektif merupakan campuran dari perasaan-perasaan seseorang, diperlukan lebih dari satu indikator yang dapat mewakili seluruh perasaan responden.
Indikator-indikator ini dapat ditemukan pada Var 11, Var 21, dan Var 36. Untuk menghindari adanya bias selama wawancara, ketiga indikator tersebut sengaja ditempatkan berjauhan satu sama lain dalam lembar wawancara. Hal ini dilakukan dengan tujuan:

- menghindari adanya pengaruh dari pertanyaan sebelumnya

- menghindari adanya tendensi untuk memanipulasi atau mengarahkan jawaban pada salah satu kesimpulan.

\section{(VAR 11) Perasaan sejahtera}

Ukuran atau pengertian sejahtera diserahkan pada responden sendiri. Jangan memberikan pengertian atau ukuran. Jika responden tidak paham dengan kata "sejahtera", silakan gunakan kata yang sepadan dalam bahasa setempat. Misalnya, untuk masyarakat Benuaq (salah satu suku di Kutai Barat) dapat menggunakan kata "bolupm bue". Jika Anda tidak dapat berbahasa setempat, tanyalah pada orang yang dapat berbahasa setempat dan juga dapat berbahasa Indonesia.

\section{(VAR 21) Perasaan miskin}

Pengertian dan kriteria miskin diserahkan sepenuhnya pada responden. Jangan terpancing untuk menjelaskan kriteria atau pengertiannya. Jika responden tidak paham kata "miskin", carilah kata yang sepadan dalam bahasa setempat yang digunakan responden.

\section{(VAR 36) Perasaan bahagia}

Pengertian dan kriteria bahagia diserahkan sepenuhnya pada responden. Jangan terpancing untuk menjelaskan kriteria atau pengertiannya. Jika responden tidak paham kata "bahagia", carilah kata yang sepadan 
dalam bahasa setempat yang digunakan responden.

\section{Kesejahteraan Inti}

Kesejahteraan dasar dibagi menjadi tiga indeks yaitu: (1) kesehatan dan gizi, (2) kekayaan materi, dan (3) pengetahuan.

\section{$\underline{\text { Kesehatan dan gizi: }}$}

\section{(VAR 12)}

(VAR 13)

\section{Kekurangan makanan}

Untuk mengetahui tingkat kerentanan rumah tangga dari segi makanan. Masa satu bulan adalah batas waktu bagi rumah tangga yang berada dalam situasi kekurangan bahan makanan yang serius. Kekurangan bahan makanan tidak berarti tidak makan, tetapi kesulitan untuk mendapatkan bahan makanan, sehingga rumah tangga tersebut harus makan dengan pola yang tidak wajar. Misalnya, rumah tangga tersebut harus sering makan dengan singkong atau umbi-umbian sebagai pengganti beras, atau sangat sulit mendapatkan sumbersumber protein seperti ikan, daging, ayam, dan telur.

\section{Akses kepada air minum bersih}

Untuk mengetahui apakah rumah tangga mendapatkan air bersih. Arti air bersih diserahkan kepada responden sendiri. Air bersih tidak harus air ledeng (misalnya: dari Perusahaan Daerah Air Minum, PDAM). Bagaimana responden mendapatkan air bersih, tidak penting untuk diketahui. Yang ingin diketahui adalah apakah responden mendapatkan air bersih atau tidak.
(VAR 14)

\section{Akses kepada pelayanan kesehatan}

Untuk mengetahui daya jangkau rumah tangga pada pelayanan kesehatan saat ada anggota rumah tangga yang sakit. Pelayanan kesehatan bisa berupa pelayanan medis seperti dokter, bidan, perawat, dll, bisa juga pelayanan tradisional seperti dukun, beliatn, tanaman obat, obat hutan dll. Dalam hal ini, tidak penting untuk diketahui bagaimana rumah tangga tersebut bisa mendapatkan pelayanan kesehatan, termasuk jika responden ternyata harus berhutang untuk itu. Yang ingin diketahui adalah: apakah rumah tangga tersebut mendapatkan pelayanan kesehatan sewaktu ada yang sakit. Jika tidak pernah ada yang sakit dalam 12 bulan terakhir maka responden harus mendapatkan skor paling tinggi.

\section{Kekayaan materi:}

(VAR 15)

\section{Kondisi rumah}

Untuk mengetahui kondisi rumah responden. Rumah yang dinilai adalah rumah yang ditempati dan berada di desanya. Rumah milik responden yang berada di luar desa dapat diabaikan. Penilaian kondisi rumah dilakukan oleh pendata sendiri (tidak ditanyakan pada responden). Berikut adalah kriteria yang digunakan di Kutai Barat (sebagai contoh):

Rumah di atas standar:

- Kayu yang digunakan sebagian besar kayu bangkirai atau ulin, atau terbuat dari beton (semen dan pasir)

- Ada jendela kaca

- Bahan masih dalam keadaan baik. 


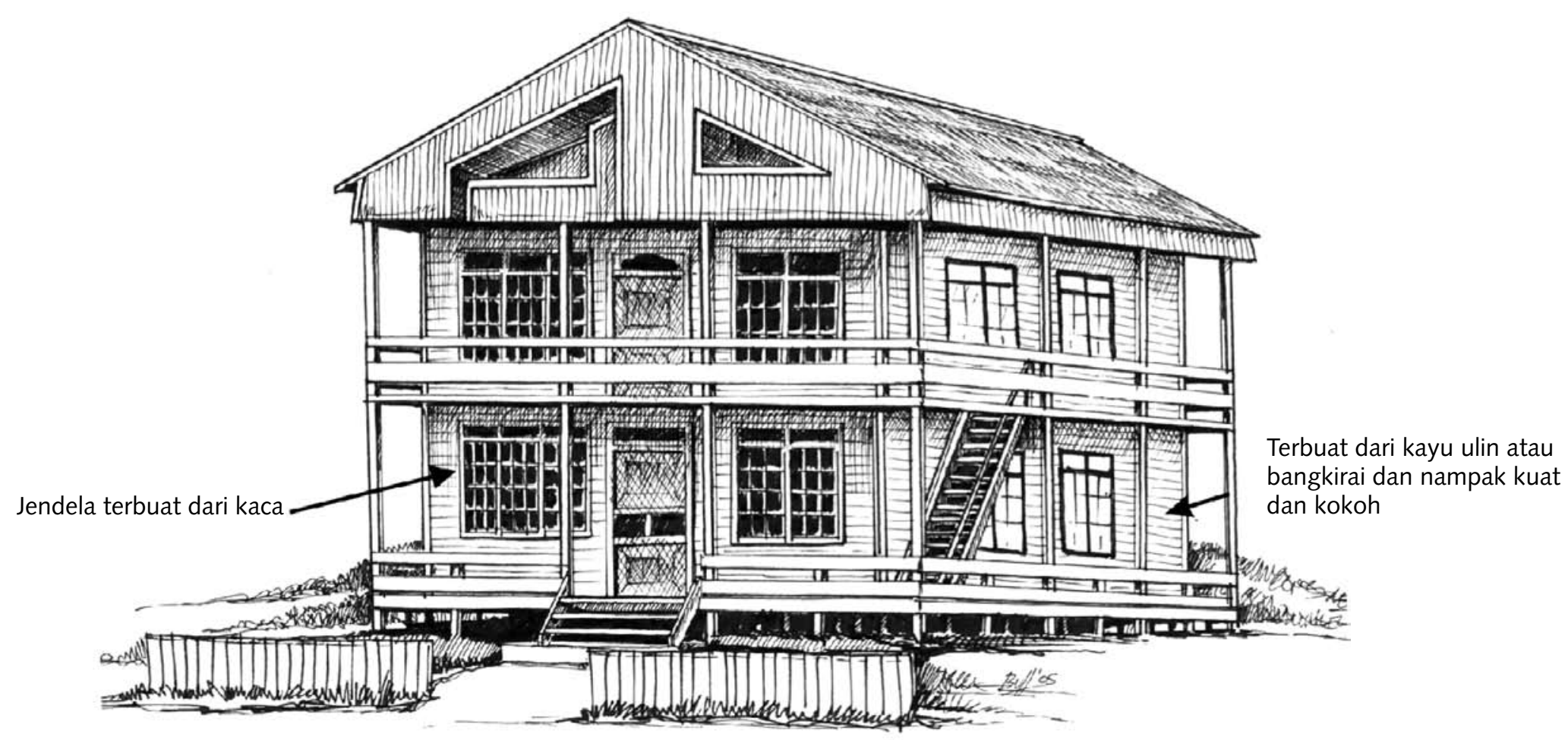

Gambar 5.1. Rumah di atas standar 


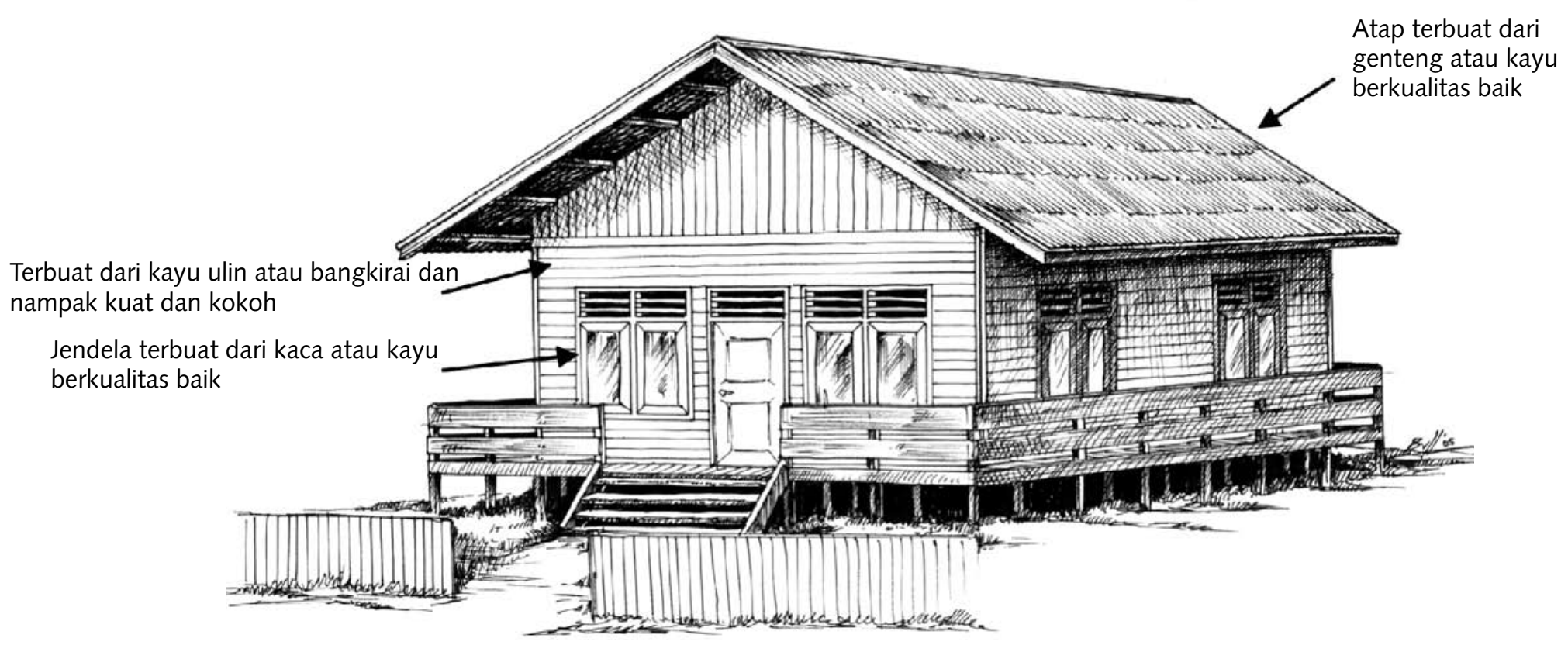

Gambar 5.2. Rumah di atas rata-rata 
Rumah standar rata-rata:

- Terbuat dari kayu selain jenis ulin dan bangkirai

- Secara keseluruhan rumah dalam keadaan baik walaupun mungkin perlu beberapa perbaikan kecil

Kayu bukan dari jenis ulin atau bangkirai tetapi masih dalam keadaan baik

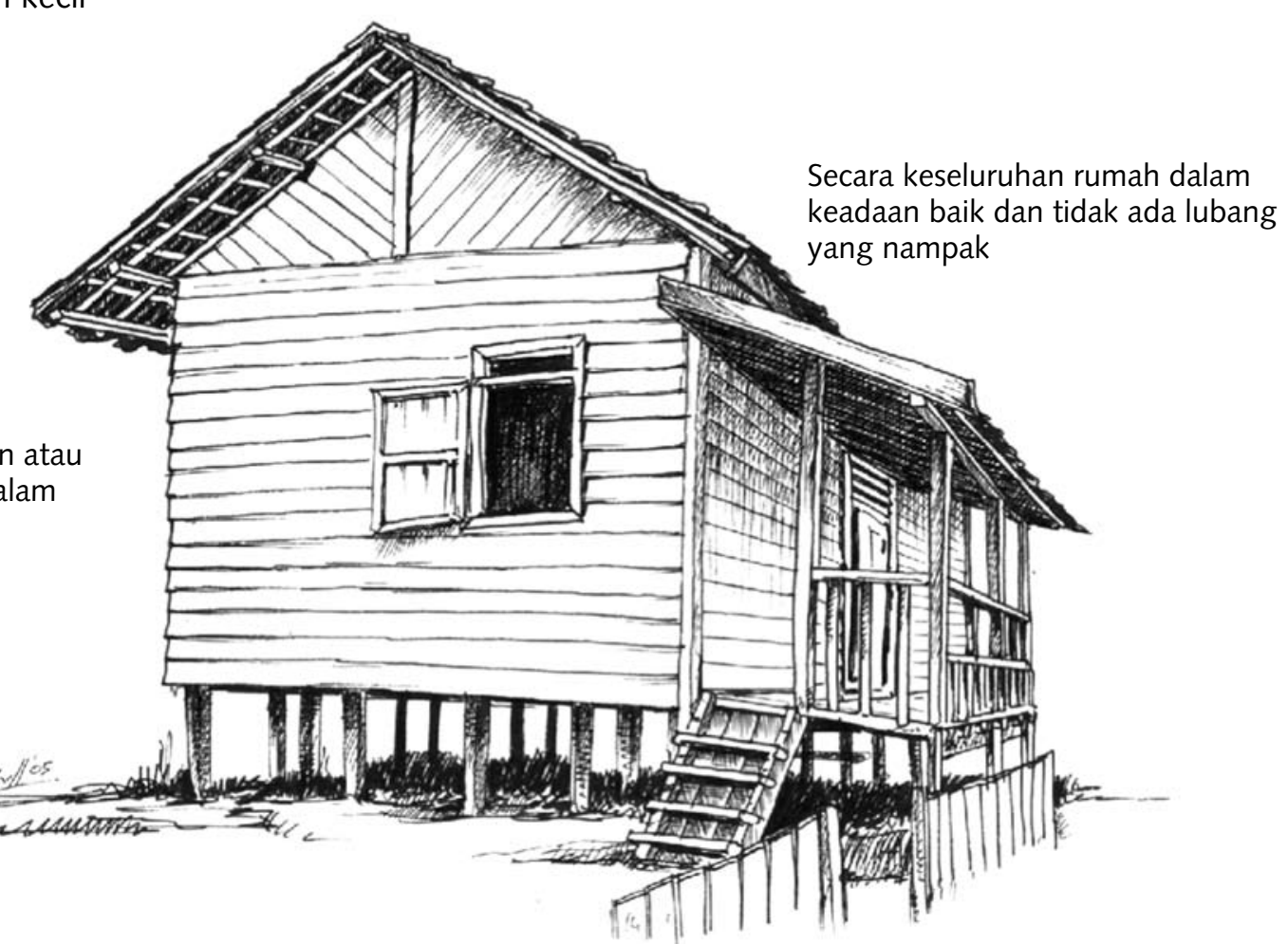

Gambar 5.3. Rumah standar rata-rata 
Secara keseluruhan rumah dalam keadaan baik tidak ada lubang yang nampak

Kayu bukan dari jenis ulin atau bangkirai tetapi masih dalam keadaan baik

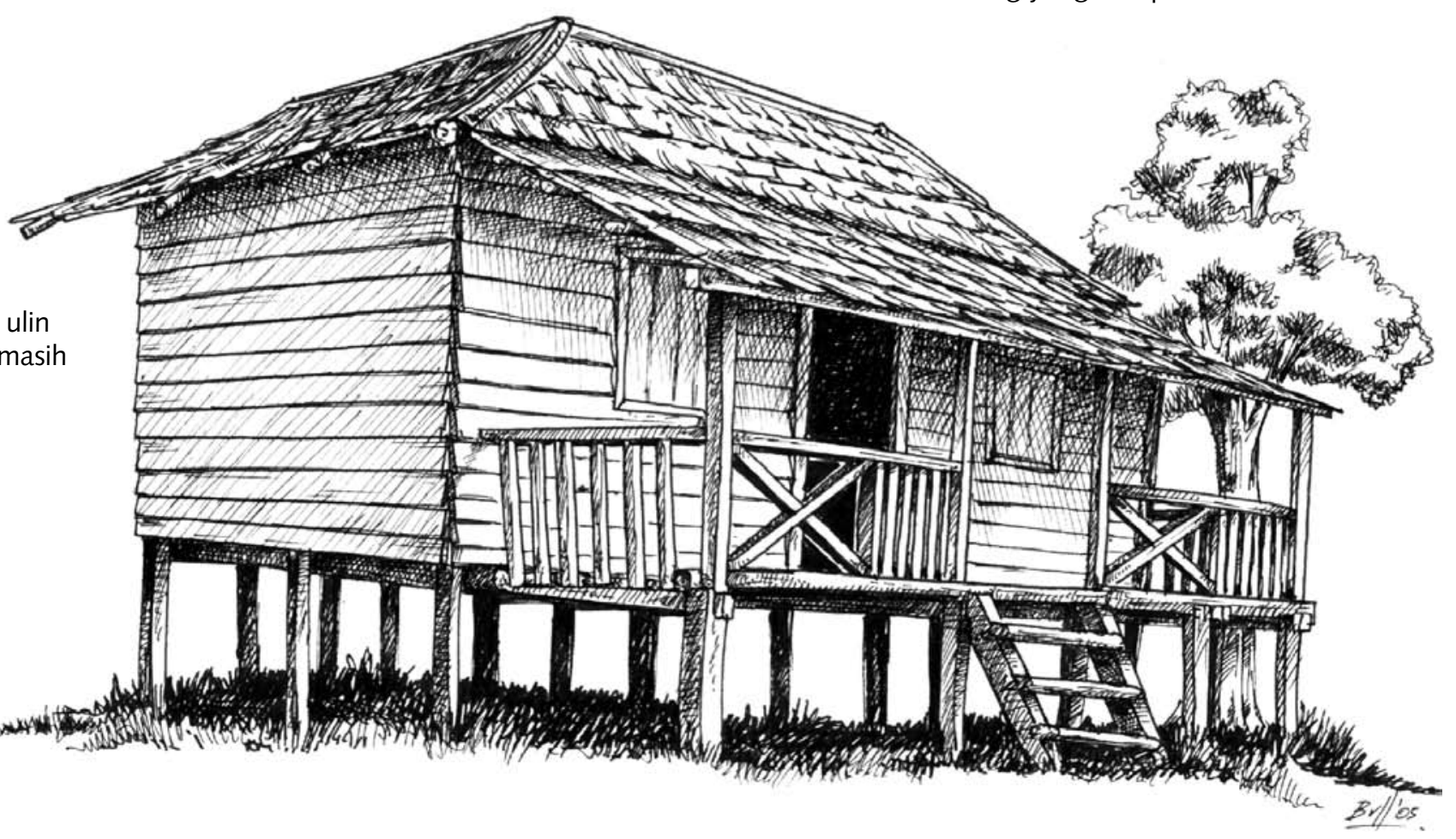

Gambar 5.4. Rumah standar rata-rata 
Rumah di bawah standar:

- Rumah sudah terlihat rusak

- Beberapa lubang nampak di atap, lantai atau dinding

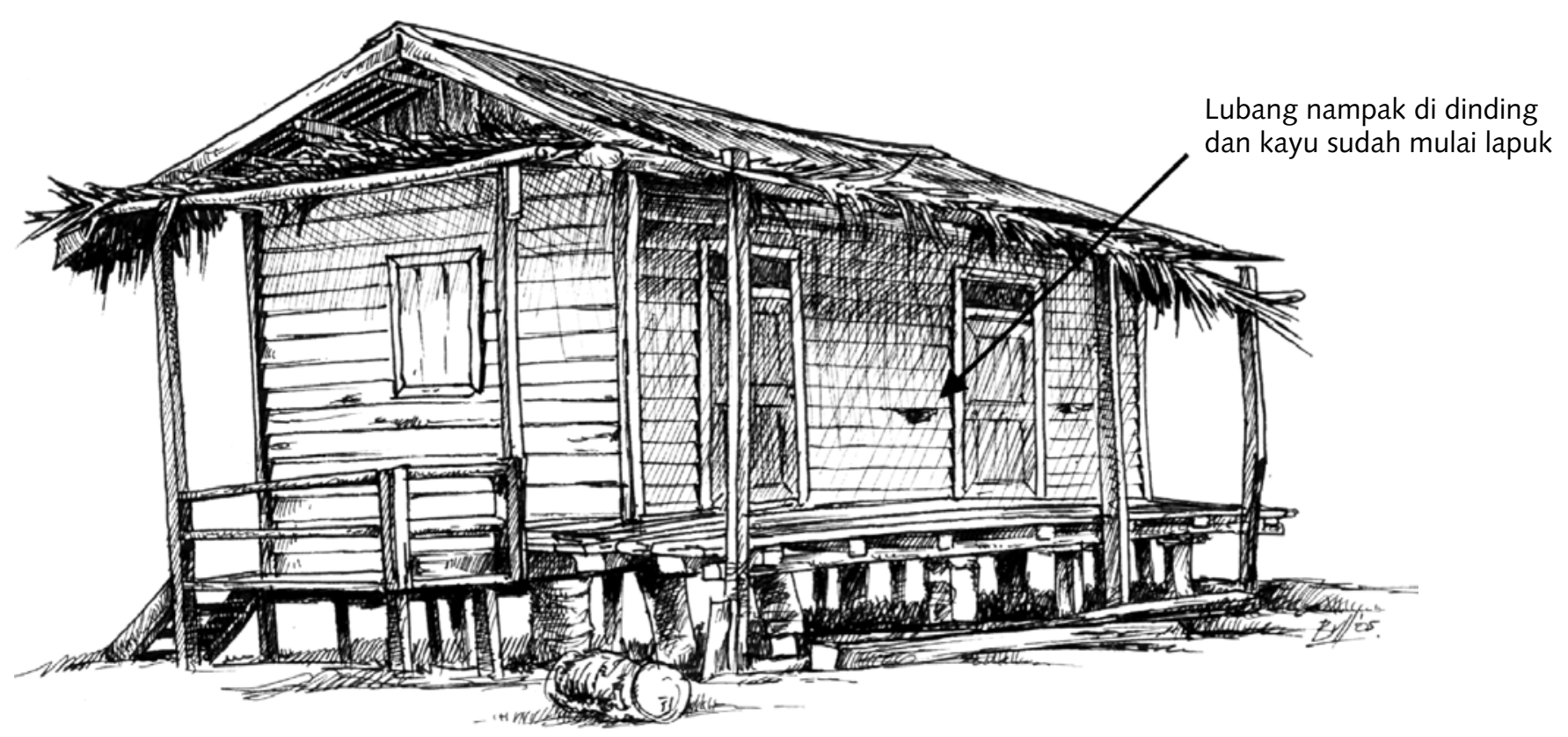

Gambar 5.5. Rumah di bawah standar 


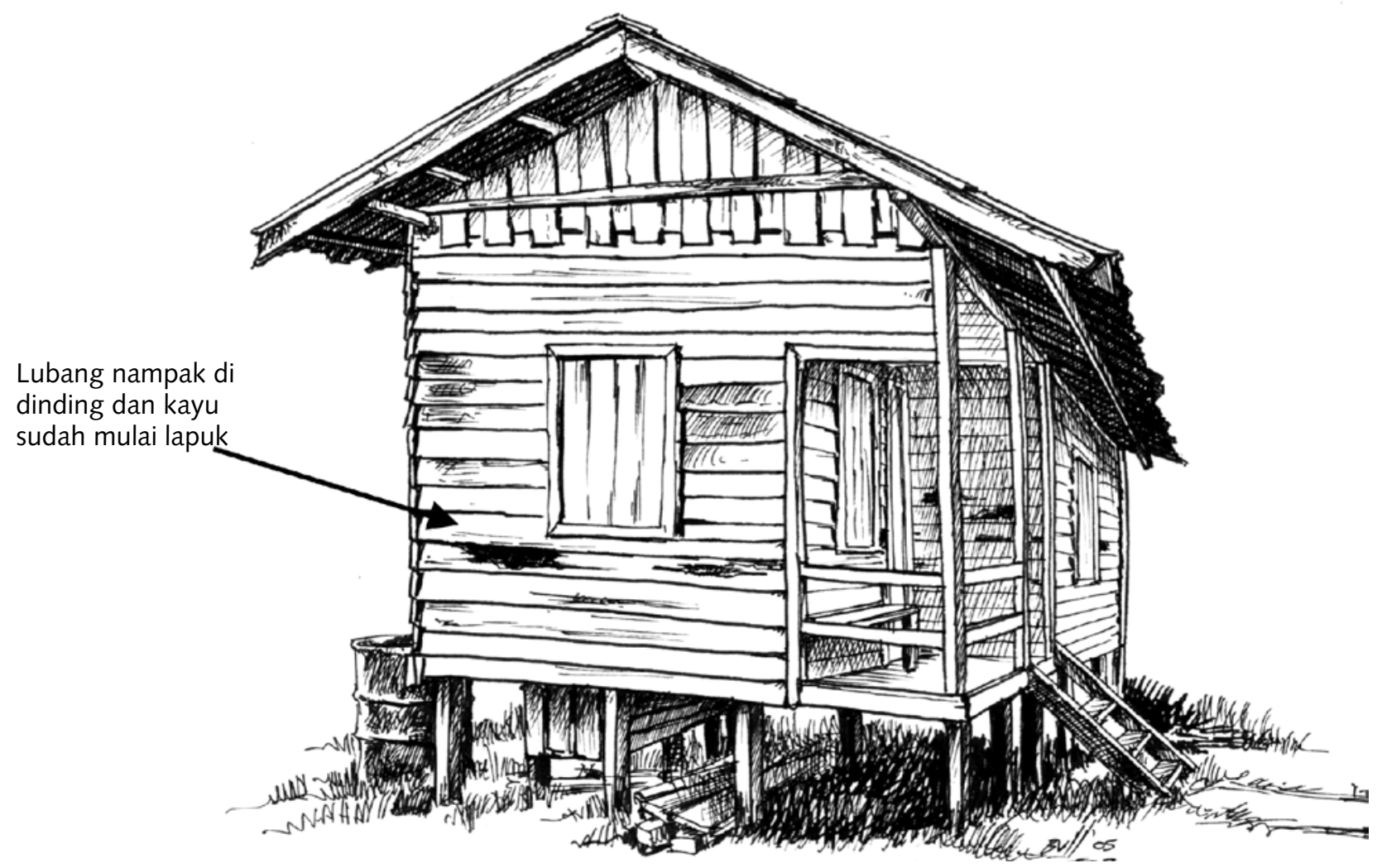

Gambar 5.6. Rumah di bawah standar 
(VAR 16)

Memiliki sepeda motor atau mesin ces/mesin spid

Untuk melihat tingkat kekayaan materi suatu rumah tangga. Pendata harus melihat sendiri dan tidak usah ditanyakan pada responden (pendata adalah warga setempat, jadi dia mengenal keadaan tetangganya). Sepeda motor biasanya dimiliki oleh masyarakat yang tinggal di daratan, sedangkan mesin ces/mesin spid dimiliki masyarakat di daerah perairan. Karena itu, bagian ini mencakup sepeda motor atau mesin ces/mesin spid. Sehingga rumah tangga yang bersangkutan cukup hanya memiliki salah satu di antaranya, tidak perlu keduanya. Informasi tentang kapan barang itu dibeli dan bagaimana keadaannya dapat diabaikan saja, kecuali kalau barang tersebut sudah menjadi rongsokan yang sama sekali tidak mungkin digunakan atau diperbaiki.

\section{(VAR 17) Memiliki antena parabola atau kulkas}

Juga untuk melihat tingkat kekayaan materi suatu rumah tangga. Pendata harus melihat sendiri dan tidak usah ditanyakan pada responden. Penggunaan kata 'atau' berarti tidak perlu keduanya. Tidak penting kapan barang itu dibeli dan bagaimana keadaannya.

Pengetahuan:

(VAR 18) Tingkat pendidikan (formal) orang dewasa Untuk mengetahui tingkat pengetahuan rumah tangga yang tercermin lewat pendidikan formal (sekolah). Di sini diasumsikan bahwa semakin tinggi sekolahnya, semakin tinggi juga pengetahuannya. Anggota rumah tangga dewasa adalah yang sudah berusia 17 tahun atau lebih atau sudah berkeluarga.
(VAR 19) Jumlah anak yang bersekolah atau putus sekolah Untuk mengetahui tingkat partisipasi atau putus sekolah pada usia pendidikan dasar (7 s/d 16 tahun). Anak-anak tidak harus anak kandung responden, bisa juga anak angkat, cucu, keponakan, sepupu, dsb. Yang dimaksud dengan "anak-anak" adalah seluruh anak-anak yang tinggal atau menjadi tanggungan rumah tangga responden. Anak-anak titipan yang masih ditanggung oleh keluarga asalnya tidak dihitung. Nilai 3 (tiga) diberikan pada rumah tangga yang tidak memiliki anak usia pendidikan dasar. Ini dilakukan agar rumah tangga tersebut mendapatkan nilai tertinggi. Dengan tidak adanya anak usia pendidikan dasar, maka tidak ada kewajiban bagi pemerintah untuk menjamin pendidikan.

\section{(VAR 20) Pengetahuan informal}

Untuk mengetahui tingkat pengetahuan yang tidak didapatkan di sekolah (informal). Ini dapat melengkapi indikator pendidikan formal. Pengetahuan informal dapat meningkatkan kesempatan bagi rumah tangga untuk meningkatkan penghidupannya. Pengetahuan ini harus merupakan pengetahuan di luar pengetahuan atau keterampilan pertanian. Ini dilakukan untuk mengidentifikasi perbedaan karena keterampilan pertanian biasanya cukup merata di masyarakat pedesaan. Pengetahuan informal tidak harus yang dapat menghasilkan uang.

\section{Lingkungan Pendukung (Konteks)}

Lingkungan pendukung terdiri dari lima indeks, yaitu: (1) lingkungan alam, (2) lingkungan ekonomi, (3) lingkungan 
sosial, dan (4) lingkungan politik, dan (5) infrastruktur dan pelayanan.

Catatan: Var 22 sebenarnya bukan indikator, tapi hanya variabel untuk membedakan antara kelompok responden dan untuk menentukan tingkat ketergantungan masyarakat pada sumber daya alam.

\section{Lingkungan alam:}

\section{(VAR 22) Frekuensi kunjungan ke hutan atau danau}

Pertanyaan ini bertujuan untuk mengetahui seberapa sering responden pergi ke hutan atau danau. Informasi ini bermanfaat untuk mengetahui hubungan responden dengan alam, juga untuk mengetahui tingkat kepercayaan jawabannya pada aspek lingkungan alam.

\section{(VAR 23a/b) Tingkat kerusakan lingkungan alam}

Untuk mengetahui tingkat kerusakan alam di wilayah desa yang salah satunya diketahui melalui terjadinya kebakaran hutan dalam 12 bulan terakhir. Pengertian rusak diserahkan kepada penilaian responden sendiri. Kebakaran hutan tidak termasuk kebakaran untuk persiapan ladang, kecuali bila persiapan ladang tidak dilakukan dengan baik sehingga api menyebar ke luar lokasi yang dipersiapkan sebagai ladang.

\section{(VAR 24)}

\section{Keberadaan Burung Enggang atau Bangau Tongtong}

Untuk mengetahui tingkat keanekaan hayati yang ada di wilayah desa. Burung Enggang dan Bangau Tongtong digunakan untuk mewakili jenis-jenis keragaman makhluk hidup, Burung Enggang untuk wilayah daratan, sedangkan
Bangau Tongtong untuk wilayah danau. Jika responden tidak mengetahui Burung Enggang atau Bangau Tongtong, bantu dengan cara menerjemahkannya ke dalam bahasa setempat atau menunjukkan gambarnya.

(VAR 25)

\section{Pengambilan sumber daya alam secara berlebihan}

Untuk melihat metode yang digunakan dan seberapa banyak sumber daya alam yang diambil di desa tersebut. Pengambilan yang berlebihan akan menghabiskan beberapa 'produk' alam, sehingga dapat menutup kesempatan bagi masyarakat lain untuk mendapatkan manfaat dari sumber daya alam tersebut. Habisnya sumber daya alam yang dimaksud di sini adalah sumber daya alam yang habis dalam 12 bulan terakhir. Kata "habis" tidak berlaku untuk spesies musiman yang tidak ada saat ini, seperti ikan. Harap diingat bahwa skor 1 harus diberikan bila nyaris tidak ada sumber daya alam yang tersisa!

(VAR 26) Mutu air

Untuk mengetahui keadaan lingkungan dari sisi kualitas air. Keadaan air sungai atau danau dapat memberikan informasi penting tentang kualitas lingkungan desa. Penilaian keadaan diserahkan sepenuhnya pada penilaian responden sendiri.

\section{Lingkungan ekonomi:}

Pertanyaan tentang lingkungan ekonomi dimulai dengan pertanyaan mengenai sumber penghasilan.

(VAR 27) Sumber penghasilan Var 27 sebenarnya bukan indikator, melainkan 
pertanyaan variabel normal yang dimaksudkan untuk mengetahui jenis-jenis sumber penghasilan dan sejauh mana penghasilan bergantung pada sumber daya alam.

\section{(VAR 28a/b) Stabilitas penghasilan}

Untuk mengetahui apakah rumah tangga tersebut memiliki lebih dari satu sumber penghasilan, juga untuk mengetahui apakah penghasilan tersebut tetap (stabil). Pilihan penghasilan penting untuk mengurangi potensi kerentanan yang disebabkan oleh ketergantungan pada satu sumber penghasilan. Kalimat "Ada yang tetap" tidak berarti seluruh sumber penghasilan harus tetap, bisa hanya salah satunya saja. Penghasilan tetap adalah penghasilan yang stabil yang mampu memberikan rasa aman karena dirasakan masih akan ada di masa depan dalam jangka waktu yang relatif panjang. Umumnya penghasilan tetap selalu bisa diterima secara teratur. Gaji bulanan dapat dianggap penghasilan tetap, sedangkan gaji harian tidak bisa

(PILIH PALING BANYAK 3 SUMBER PENDAPATAN PALING PENTING) Dalam 12 bulan terakhir, apa sumber-sumber pendapatan uang paling diandalkan bagi rumahtangga anda?

\begin{tabular}{|c|l|c|l|}
\hline $\mathbf{1}$ & Dagang & $\mathbf{1 1}$ & Fee lain/ganti rugi \\
\hline $\mathbf{2}$ & Fee kayu & $\mathbf{1 2}$ & Honor pengurus kampung \\
\hline $\mathbf{3}$ & Gaji PNS atau swasta & $\mathbf{1 3}$ & $\begin{array}{l}\text { Pertanian ( sayur, kopi, ternak, } \\
\text { tambak) }\end{array}$ \\
\hline $\mathbf{4}$ & Dukungan keluarga & $\mathbf{1 4}$ & Ikan (dari sungai atau danau) \\
\hline $\mathbf{5}$ & Karet & $\mathbf{1 5}$ & Gaharu \\
\hline $\mathbf{6}$ & Rotan & $\mathbf{1 6}$ & Berburu \\
\hline $\mathbf{7}$ & Sarang burung & $\mathbf{1 7}$ & Hasil hutan lainnya \\
\hline $\mathbf{8}$ & Kayu & $\mathbf{1 8}$ & Pelayanan (tukang, bengke1,d11) \\
\hline $\mathbf{9}$ & Kerajinan tangan & $\mathbf{1 9}$ & Lainnya (sebutkan) \\
\hline $\mathbf{1 0}$ & Kios/Warung/Toko & &
\end{tabular}

Gambar 5.7 Sumber-sumber Penghasilan karena biasanya hanya bersifat sementara. Penghasilan dari hasil menyadap karet dapat dianggap sebagai penghasilan tetap, sepanjang sudah terbukti bahwa tidak pernah ada kesulitan dalam mencari pembeli dan kebun karet tersebut tidak pernah terbakar.

\section{(VAR 29a/b) Persediaan beras dan kemampuan membeli beras}

Untuk mengetahui kemampuan memenuhi kebutuhan pangan, dan beras merupakan indikatornya. Rumah tangga yang memiliki persediaan beras cukup sampai satu musim tanam tanpa harus membeli akan mendapatkan nilai tertinggi karena mereka tidak memiliki resiko kekurangan beras. Rumah tangga yang menggantungkan pemenuhan berasnya dari membeli dianggap tidak memiliki persediaan beras, sehingga harus diketahui kemampuannya dalam membeli beras. Responden yang bekerja sebagai pedagang beras tetap harus ditanya tingkat kesulitannya dalam membeli beras.

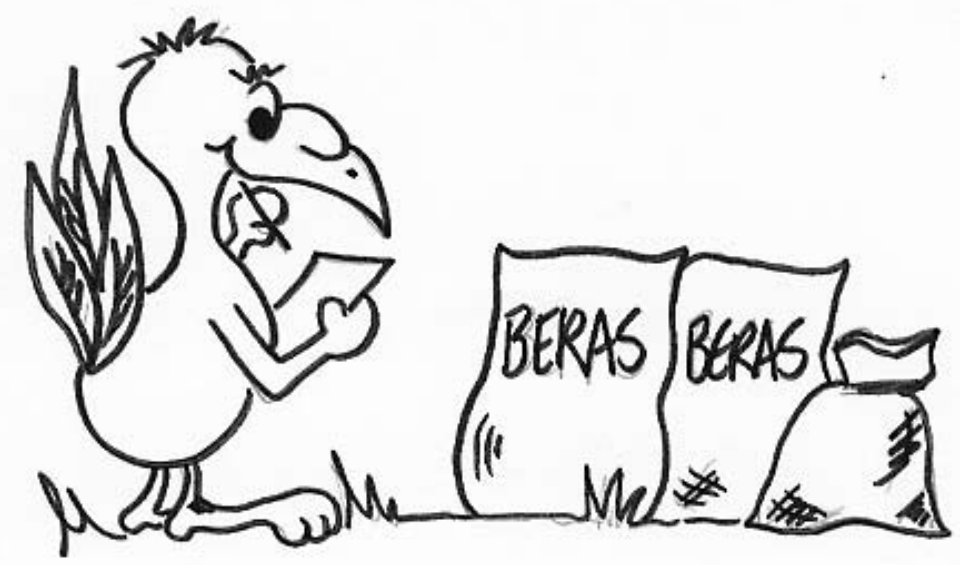




\section{(VAR 49) Akses pada kredit}

Ini untuk mengetahui seberapa sulit bagi anggota masyarakat untuk mendapatkan pinjaman usaha dari sumber apa pun (Dinas PMD, Koperasi Simpang Pinjam, dan Bank). Sebagai contoh: Pemerintah Kabupaten Kutai Barat, melalui Dinas Pemberdayaan Masyarakat memiliki program pemberian pinjaman lunak untuk usaha kecil dan menengah (UKM).

\section{Lingkungan sosial:}

\section{(VAR 30) Tingkat tolong-menolong}

Untuk mengetahui sejauh mana responden merasakan bahwa anggota masyarakatnya saling tolong-menolong. Tingkat tolongmenolong merupakan indikator kuat untuk mengetahui keterikatan sosial antar masyarakat. Tolong-menolong tidak selalu harus memberikan uang, dapat juga berupa pertolongan tenaga saat ada acara-acara adat.

\section{(VAR 31) Tingkat rasa saling percaya}

Untuk mengetahui tingkat rasa saling percaya antar masyarakat di desa. Penilaian rasa saling percaya dinilai sepenuhnya menurut perasaan responden sendiri.

\section{(VAR 32) Konflik}

Konflik sangat mempengaruhi seberapa aman atau damai keadaan yang dirasakan orang dalam masyarakatnya.

Lingkungan politik:

(VAR 33)

\section{Akses kepada sumber daya alam}

Untuk mengetahui daya jangkau rumah

tangga responden terhadap sumber daya alam di desanya sendiri. Tingkat keterjangkauan ini sangat mempengaruhi penghidupan masyarakat di pedesaan. Istilah "kesulitan" pada pilihan jawaban dapat disebabkan oleh jarak, ketiadaan alat transportasi, ketiadaan teknologi, kelangkaan atau larangan hukum. "Boleh tanpa kesulitan" mungkin masih dibatasi oleh batasan-batasan tertentu, misalnya untuk menjaga kelestarian tidak boleh menyetrum ikan, mengambil kayu dengan alat berat, dll.

\section{(VAR 34) Akses kepada informasi}

Untuk melihat akses kepada informasi di tingkat rumah tangga. Berita atau informasi sehari-hari adalah berita atau informasi harian yang didapat setiap hari.

\section{(VAR 35) Keikutsertaan dalam pengambilan keputusan} di tingkat desa

Untuk mengetahui tingkat keikutsertaan masyarakat dalam pengambilan keputusan di tingkat desa. Walaupun sudah ada Badan Perwakilan Desa (BPD) tetapi proses konsultasi BPD dengan masyarakat harus tetap ada. Seringkali di desa-desa kecil, mekanisme musyawarah bersama lebih kuat dibandingkan dengan BPD.

\section{Ketergantungan pada Hutan}

Modul ketergantungan hutan bertujuan untuk melihat tingkat ketergantungan masyarakat pada hutan. Hal ini penting bagi masyarakat di daerah yang masih memiliki keterikatan dengan hutan seperti masyarakat di Kabupaten Kutai Barat. Modul ini tidak perlu ditanyakan setiap tahun. 


\section{(VAR 37) Berladang dan hasil panen}

Untuk mengetahui apakah rumah tangga tersebut mendapatkan hasil panen dari musim panen tahun lalu.

\section{(VAR 38) Umur lahan untuk ladang}

Untuk mengetahui kisaran umur lahan yang dibuka untuk ladang yang paling baru.

Beberapa suku biasanya memiliki istilah sendiri yang dapat menggambarkan umur lahan untuk ladang. Misalnya di masyarakat Benuaq ada istilah bengkar, batakng, urat, kloako, babar, kerengkakng.

\section{(VAR 39) Tingkat kepentingan hasil hutan bukan kayu} Untuk mengetahui ketergantungan responden pada hasil hutan bukan kayu. Tingkat kepentingan berkaitan dengan ketergantungan rumah tangga terhadap hasil hutan bukan kayu baik untuk nafkah/penghasilan maupun untuk dipakai sehari-hari.

\section{(VAR 40) Tingkat kepentingan hewan buruan}

Untuk mengetahui ketergantungan responden pada hewan buruan. Tingkat kepentingan berkaitan dengan ketergantungan rumah tangga terhadap hewan buruan (sebagai salah satu hasil hutan), baik untuk penghasilan maupun untuk dipakai sehari-hari.

\section{Infrastruktur dan Layanan}

Bagian struktur dan pelayanan dibuat untuk menggambarkan fasilitas pendukung, baik berupa pelayanan, fasilitas fisik maupun kelembagaan. Bagian ini akan memberikan informasi tentang program-program yang berpotensi untuk mempengaruhi lingkungan pendukung, pemenuhan kebutuhan dasar, dan bahkan perasaan subyektif. Beberapa indikator yang dipilih (Var 41, 42, 44, 45, 50, 51, 52, 56) membentuk lingkungan infrastruktur dan pelayanan dalam model NESP, sedangkan indikator lainnya memberi informasi tambahan tentang program-program pemerintah.

(VAR 41) Fasilitas pendidikan dasar (sekolah menengah pertama)

Untuk mengetahui tingkat kesulitan masyarakat dalam menjangkau SMP terdekat. Indikator ini menunjukan keberadaan dan kualitas infrastruktur bangunan sekolah. Penilaian tingkat kesulitan diserahkan kepada responden sendiri.

\section{(VAR 42) Kualitas pendidikan di sekolah}

Untuk mengetahui kualitas layanan pendidikan formal. Indikator ini mencerminkan seluruh faktor dalam pelayanan seperti guru, fasilitas pendidikan, dll. Penilaian kualitas diserahkan kepada responden sendiri.

\section{(VAR 43) Distribusi beasiswa}

Untuk mengetahui penyebaran program beasiswa di masyarakat. Beasiswa dapat berasal dari mana saja, tidak harus dari pemerintah.

(VAR 44) Fasilitas pelayanan kesehatan Untuk mengetahui tingkat kesulitan masyarakat dalam menjangkau pusat pelayanan kesehatan terdekat. Indikator ini menunjukkan cakupan pelayanan kesehatan. Penilaian tingkat kesulitan diserahkan kepada responden sendiri.

(VAR 45) Kualitas pelayanan kesehatan Untuk mengetahui kualitas pelayanan 
kesehatan. Indikator ini mencerminkan seluruh faktor dalam pelayanan kesehatan seperti tenaga kesehatan (dokter, perawat, dll.), fasilitas perawatan, obat-obatan, dll. Penilaian kualitas pelayanan diserahkan kepada responden sendiri.

\section{(VAR 46) Distribusi kartu ASKES GAKIN (KIN)}

Untuk mengetahui penyebaran program bantuan asuransi kesehatan (ASKES) dan Keluarga Miskin (GAKIN). ASKES GAKIN adalah Asuransi Kesehatan bagi Keluaga Miskin, yang merupakan program pemerintah untuk membantu keluarga miskin agar dapat tetap berobat ketika sakit. Kartu ASKES KIN dikeluarkan oleh Departemen Kesehatan sebagai bagian dari program kompensasi pengurangan subsidi bahan bakar minyak (BBM).

(VAR 47) Distribusi kartu Bantuan Langsung Tunai (BLT) Kartu bantuan langsung tunai disebarkan oleh PT Pos Indonesia berdasarkan data keluarga miskin dari BPS. Dengan kartu ini, keluarga miskin bisa mendapatkan bantuan tunai sebesar Rp.100.000 per bulan. Program ini merupakan bagian dari program pemerintah pusat sebagai kompensasi pengurangan subsidi BBM.

(VAR 48)

\section{Distribusi Beras untuk Masyarakat Miskin (Raskin)}

Untuk mengetahui penyebaran beras untuk masyarakat miskin (Raskin). Raskin adalah beras yang diperoleh dari program bantuan beras pemerintah untuk rumah tangga miskin.
(VAR 50)

\section{Pelatihan dan pendampingan usaha}

Untuk mengetahui adanya pelayanan pelatihan dan pendampingan usaha sebagai bagian penting dalam pengembangan ekonomi. Hal ini mencakup seluruh bentuk bantuan usaha, termasuk pertanian.

(VAR 51) Kondisi jalan dan jembatan

Untuk mengetahui kondisi jalan dan jembatan sampai ke ibukota kecamatan. Jalan dan jembatan adalah akses penting yang dampaknya dapat mempengaruhi hampir seluruh aspek kehidupan. Penilaian kondisi jalan diserahkan kepada responden masingmasing.

(VAR 52) Fasilitas pasar

Untuk mengetahui seberapa sulit masyarakat menjangkau pasar terdekat. Pasar di sini dapat berupa pasar tetap ataupun musiman (misalnya Pasar Minggu) yang dicirikan dengan adanya tempat-tempat khusus berjualan, baik permanen maupun semi permanen. Pasar keliling yang tidak memiliki tempat khusus untuk menjual barang tidak termasuk dalam kategori ini. Penilaian tingkat kesulitan diserahkan kepada responden sendiri.

(VAR 53) Bantuan untuk rumah tidak layak huni Untuk mengetahui penyebaran program bantuan rumah tidak layak huni. Program ini bertujuan untuk membantu rumah tangga miskin dalam memperbaiki rumahnya yang rusak. Program ini diberikan oleh Dinas Pemberdayaan Masyarakat. 
(VAR 54)

Persepsi terhadap program pemerintah

Untuk mengetahui persepsi masyarakat terhadap mutu dan jumlah program pemerintah di desanya. Yang dimaksud pemerintah mencakup pemerintah pusat, propinsi, kabupaten, kecamatan dan desa.

Persepsi diserahkan kepada masyarakat sendiri.

(VAR 55) Persepsi terhadap program non pemerintah Untuk mengetahui persepsi masyarakat terhadap mutu dan jumlah program dari pihak non-pemerintah, seperti LSM, perusahaan, ormas, organisasi keagamaan, dan partai politik, tetapi bukan dari DPRD.

\section{(VAR 56) Fasilitas komunikasi}

Untuk mengetahui daya jangkau masyarakat terhadap fasilitas komunikasi seperti telepon, telepon genggam/seluler (ponsel), dan radio.

\section{(VAR 57) Pelayanan rohani}

Untuk mengetahui daya jangkau rumah tangga terhadap pelayanan rohani. Pelayanan rohani dapat berupa tempat peribadatan, guru atau pembimbing rohani, dan perangkat-perangkat peribadatan.

\section{(VAR 58) Fasilitas rekreasi}

Untuk mengetahui daya jangkau masyarakat terhadap fasilitas rekreasi, seperti obyek wisata, sarana olahraga, atau tempat-tempat yang dapat digunakan masyarakat untuk bersantai dan menghibur diri.

(VAR 59)

\section{Pengetahuan tentang Gerakan Sendawar Makmur (GSM}

Untuk mengetahui pemahaman rumah tangga tentang program-program pembangunan daerah. Sebagai contoh, di Kutai Barat terdapat program Gerakan Sendawar Makmur (GSM, program lintas sektoral di Kabupaten Kutai Barat yang bertujuan untuk mengurangi kemiskinan). Di daerah lain mungkin ada program sejenis ini. 

Pemeriksaan Hasil Wawancara 


\section{Pemeriksaan Hasil Wawancara}

Pemeriksaan hasil pendataan adalah tanggung jawab petugas pemeriksa. Namun untuk daerah kota yang penduduknya terkumpul, mungkin pemeriksaan dilakukan oleh petugas kelurahan. Pemeriksaan dilakukan setelah pendata desa menyelesaikan pendataan di desanya masing-masing, setelah seluruh hasil pendataan (lembar wawancara terisi, sketsa pemukiman, dan Form-A) diserahkan oleh pendata desa kepada petugas pemeriksa.

Ada empat langkah yang harus dilakukan saat memeriksa hasil pendataan:

Langkah 1: Memeriksa hasil pemilihan responden

Langkah 2: Memeriksa lembar wawancara yang sudah diisi

Langkah 3: Membayar honor dan ongkos transportasi pendata desa

Langkah 4: Membungkus dan menyegel lembar wawancara

\section{Langkah 1: Memeriksa Hasil Pemilihan Responden}

Dua hal berikut dapat digunakan saat memeriksa hasil pemilihan responden: (1) sketsa perumahan, dan (2) formulir pemilihan rumah tangga responden (Form $A$ ).

1. Memeriksa penomoran rumah

Lihat peta sketsa:

Penomoran pada sketsa tidak dilakukan secara lengkap, hanya nomor rumah berpenghuni saja (kotak).

Tanda bangunan segitiga tidak perlu karena berarti tidak berpenghuni. Penomoran yang benar dicirikan dengan urutan nomor yang selalu ke arah rumah yang bersebelahan. Sedangkan penomoran yang salah dicirikan oleh urutan nomor berikutnya yang berada di seberang sungai atau jalan. Mengurut dengan cara menyeberang hanya diperbolehkan bila rumah yang bersebelahan sudah habis (lihat contoh pada Modul 3).

2. Memeriksa pemilihan responden (awal)

Lihat peta sketsa:

Rumah tangga yang dipilih sebagai responden ditandai dengan tanda silang pada kotak yang mewakili rumah tersebut.

- Jika metode loncat dua digunakan (pada desa dengan lebih dari 60 rumah tangga), maka tidak mungkin ada rumah tangga responden yang rumahnya tepat bersebelahan, kecuali pada kasus pemukiman yang tidak beraturan (tidak membentuk garis atau keteraturan posisi), atau pada kasus penggantian responden (yang dipilih dengan undian sehingga bisa jadi yang terpilih adalah rumah tangga tepat di sebelah rumah tangga responden lainnya). Persentase

Persentase dihitung dengan cara membagi jumlah dengan jumlah keseluruhan, lalu dikalikan 100 . Rumus untuk persentase rumah tangga responden terpilih adalah:

$\%=\frac{\text { Jumlah rumah tangga responden terpilih }}{\text { Jumlah seluruh rumah tangga }} \times 100$

Misalnya, ada 62 rumah tangga di Desa Durian, sementara jumlah rumah tangga responden adalah 21. Jadi persentase responden rumah tangga adalah 33,87 .

$\frac{21}{62} \times 100=33,87 \%$

Kotak 6.1. Bagaimana menghitung persentase 
responden biasanya antara 32 persen sampai dengan 35 persen jumlah total rumah tangga.

- Untuk desa dengan jumlah rumah tangga antara 21 hingga 60 yang menggunakan pemilihan dengan cara diundi, ada kemungkinan rumah responden yang terpilih bersebelahan. Jumlah rumah tangga yang bersebelahan tergantung pada jumlah rumah tangga yang ada.

- Untuk desa dengan rumah tangga berjumlah 20 atau kurang, seluruh rumah tangga terpilih bersebelahan karena pendataan dilakukan dengan cara sensus.

Lihat Form A:

- Pastikan nomor rumah tangga yang tertulis pada Form-A sama dengan nomor kotak (rumah) yang disilang pada sketsa.

- Pastikan setiap nomor rumah tangga terdiri dari 10 angka; enam angka pertama merupakan kode desa yang harus sama persis dengan ketetapan pada Lampiran 3. Sedangkan empat angka terakhir merupakan nomor rumah pada desa tersebut. Lihat penjelasan pada Modul 3 dan daftar kode desa pada Lampiran 3.

- Pastikan tidak ada dua nomor rumah tangga yang sama.

Tabel 6.1. Daftar Periksa Pendataan (Form B)

\begin{tabular}{|l|l|l|l|l|}
\hline $\begin{array}{c}\text { Nama } \\
\text { desa }\end{array}$ & Penomoran & Pemilihan & Penggantian & $\begin{array}{c}\text { Lembar } \\
\text { wawancara } \\
\text { terisi }\end{array}$ \\
\hline Desa 1 & OK & OK & 2 diganti OK & OK \\
\hline Desa 2 & Urutan salah & Salah & Tidak jelas & OK \\
\hline Desa 3 & OK & OK & OK & $\begin{array}{l}\text { 3 pertanyaan } \\
\text { tidak dijawab }\end{array}$ \\
\hline Desa 4 & OK & OK & $\begin{array}{l}\text { 3 diganti, } \\
\text { tidak diundi }\end{array}$ & OK \\
\hline Desa 5 & OK & OK & OK & $\begin{array}{l}\text { 1 pertanyaan } \\
\text { tidak dijawab }\end{array}$ \\
\hline Desa 6 & OK & OK & OK & OK \\
\hline
\end{tabular}

3. Memeriksa penggantian responden

- Pastikan responden yang diganti sudah dicoret nomornya, lalu diganti dengan nomor urut yang sama (nomor rumah tangga pasti berbeda).

Penggantinya harus diletakkan pada bagian bawah daftar.

- Pastikan responden pengganti dipilih dengan cara diundi bukan dipilih sendiri oleh pendata.

- Pastikan jumlah responden yang diganti tidak lebih dari ketentuan yang telah ditetapkan pada Form A (20 persen)

\section{Langkah 2: Memeriksa Lembar Wawancara yang Sudah Diisi}

\section{Menentukan Sampel Pemeriksaan}

- Lihat jumlah responden yang ditetapkan pada desa yang sedang diperiksa. Jumlah responden dapat dilihat pada Form A.

- Hitunglah 15 persen dari angka tersebut. Jika hasilnya berupa pecahan, bulatkan ke atas.

Jika jumlah responden di suatu desa adalah 35 rumah tangga, maka 15 persennya adalah: $35 \times 15 / 100=5,25$. Karena harus dibulatkan ke atas maka diperoleh nilai 6 (enam). Artinya Anda harus memeriksa enam lembar wawancara dari 35 lembar wawancara yang tersedia.

- Ambil 15 persen lembar wawancara terisi tersebut secara acak.

\section{Memeriksa Sampel}

- Pastikan nomor rumah tangga ditulis dengan benar.

- Periksa keterangan pada lembar wawancara. Pastikan seluruh bagian sudah terisi, baik tulisan maupun angka kodenya. Pastikan kode kecamatan dan kode desa ditulis 
dengan benar (lihat daftar kode wilayah). Kode kecamatan adalah dua angka pertama pada kode desa. Untuk lebih lengkapnya, lihat Modul 3 (Pemilihan Responden).

Contoh: Kode desa Apel yang terletak di Kecamatan Ulin adalah:

\section{2}

Kode untuk Kecamatan Ulin adalah 18.

- Periksa data dasar rumah tangga. Pastikan tidak ada yang kosong, tidak boleh ada tanda strip (-). Jika jawabannya tidak ada, maka harus diberi angka 0 (nol).

- Pastikan seluruh pertanyaan sudah dijawab.

Tip: Untuk memudahkan pemeriksaan, gunakan Form B sebagai daftar periksa.

\section{Langkah 3: Membayar Honor dan Ongkos Transportasi Pendata Desa}

Petugas pemeriksa akan memotong honor jika pendata desa tidak memenuhi standar kerja yang telah dijelaskan selama pelatihan. Misalnya, jika ada pertanyaan dalam lembar wawancara yang kosong. Hukuman untuk pendata desa yang diketahui memanipulasi pekerjaan (misalnya: tidak melakukan wawancara tetapi mengisi lembar wawancaranya sendiri) akan jauh lebih berat, yaitu tidak dibayar sama sekali dan tidak akan diperbolehkan untuk ikut kegiatan pendataan apapun di masa depan.

Jika seluruhnya berjalan baik, maka pembayaran dapat diberikan. Berikut langkah-langkah yang harus diikuti:

- Hitung apakah jumlah lembar wawancara yang terisi sama dengan jumlah rumah tangga responden (lihat formulir pemilihan rumah tangga responden). Jumlah ini harus sama. Jika ada perbedaan maka ada dua kemungkinan, yaitu: (1) kesalahan pada formulir pemilihan rumah tangga responden atau tanda terima honor pendata desa, atau (2) kelebihan atau kekurangan jumlah responden.

- Jika sudah cocok, hitung seluruh lembar wawancara yang terisi. Kalikan dengan dengan honor per kuesioner (misalnya, Rp 6.000,00) dan bayarkan jumlah yang benar. Contoh, jika jumlah lembar wawancara terisi berjumlah 39 lembar, maka honor pendata desa adalah $39 \times \mathrm{Rp}$ $6.000,00=$ Rp 234.000,00.

- Bayarkan ongkos transportasi sesuai dengan standar yang ada.

- Isi slip penerimaan pembayaran honor dan penggantian ongkos transportasi (Form C), dan minta pendata desa tersebut menandatanganinya.

- Tanda tangani lembar pernyataan bersih (Form D). Pernyataan ini merupakan tanggung jawab petugas pemeriksa terhadap hasil pemeriksaan.

\section{Langkah 4: Membungkus dan Menyegel Lembar Wawancara}

Setelah pembayaran dilakukan, tugas petugas pemeriksa selanjutnya adalah menyegel seluruh lembar wawancara. Sebelum disegel, pastikan jumlah lembar wawancara sama persis dengan jumlah yang tertera pada lembar tanda terima pembayaran pendata desa dan formulir pemilihan responden rumah tangga. Pembungkusan dilakukan dengan menggunakan map plastik yang telah disediakan.

Map plastik ini harus berisi:

1. Seluruh lembar wawancara yang sudah diisi

2. Peta sketsa pemukiman

3. Formulir pemilihan rumah tangga responden (Form A)

4. Daftar periksa pendataan (Form B)

5. Bukti pembayaran ke pendata desa (Form C)

6. Lembar pernyataan bersih (Form D)

Nomor (1) harus berada di tumpukan paling bawah dilanjutkan dengan nomor-nomor selanjutnya. Tumpukan tersebut ditutup dengan lembar pernyataan bersih (Form D) Ikat map plastik dengan tali yang tersedia. Lem penutupnya dengan isolasi yang tersedia. 
Tabel 6.2. Contoh bukti pembayaran kepada pendata desa di Kutai Barat (Form C)

\begin{tabular}{|l|l|l|l|l|l|l|l|}
\hline No. & Desa & Jumlah responden & Honor wawancara & $\begin{array}{c}\text { Ongkos transportasi } \\
\text { untuk mengantar }\end{array}$ & $\begin{array}{c}\text { Potongan karena } \\
\text { kesalahan }\end{array}$ & Total honor & Tanda tangan \\
\hline 1. & Durian & 21 & Rp 126.000,- & Rp 100.000,- & Rp 30.000,- & Rp 196.000,- & \\
\hline 2. & Mangga & 35 & Rp 210.000,- & Rp 130.000,- & Rp. 0 & Rp 340.000,-- & \\
\hline
\end{tabular}

\section{Lembar Pernyataan Bersih}

Pemantauan Kesejahteraan Kabupaten Kutai Barat tahun 2005

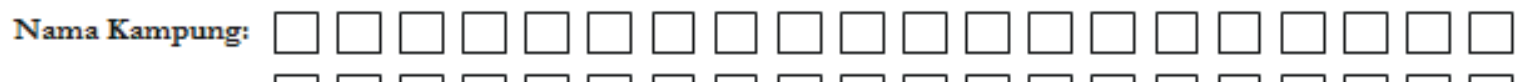

Nama Kecamatan:

Jumlah Lembar Rumahtangga:

Kode Kampung:

Jumlah Lembar Pengurus Kampung:

\begin{tabular}{|c|c|}
\hline $\begin{array}{c}\text { Diserahkan oleh Pendata Kampung } \\
\text { Tanggal: }\end{array}$ & $\begin{array}{c}\text { Seles ai Dientry Oleh Petugas Data Entry } \\
\text { T anggal: }\end{array}$ \\
\hline 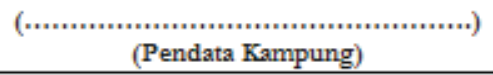 & 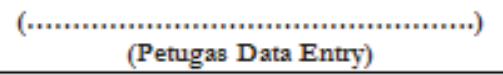 \\
\hline
\end{tabular}

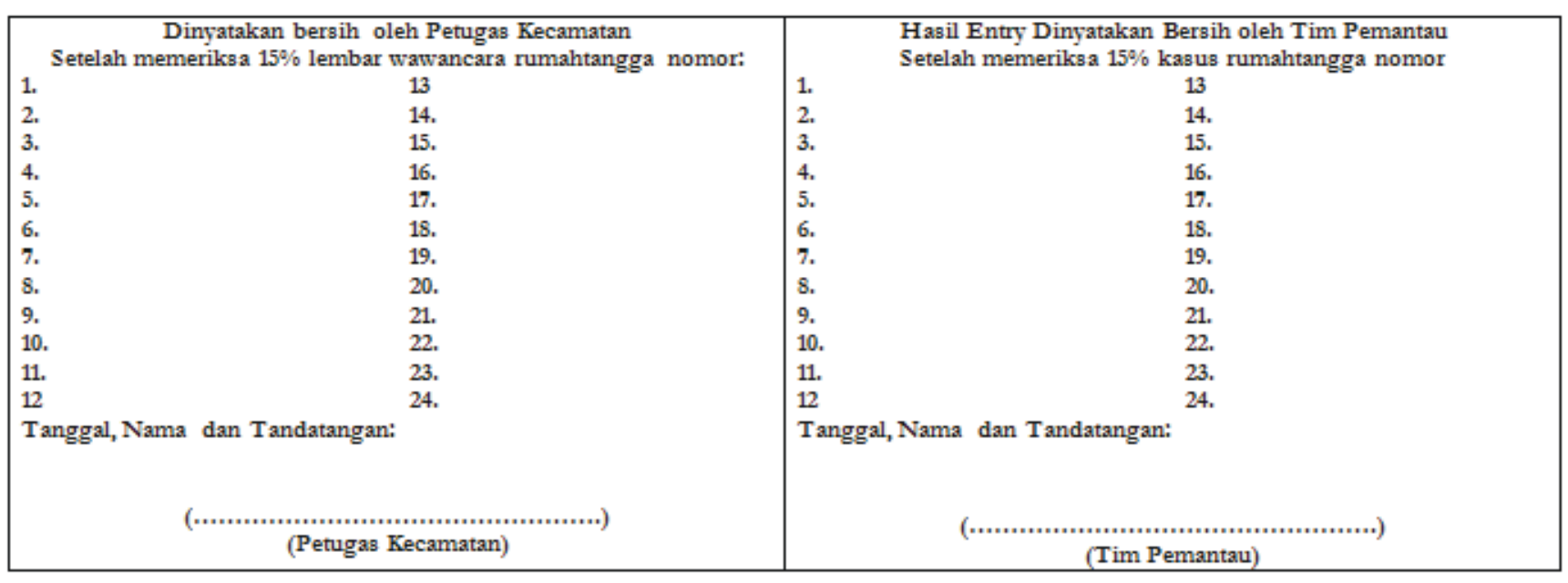

Gambar 6.1. Lembar Pernyataan Bersih (Form D) 

Memasukkan Data ke dalam SPSS 


\section{Memasukkan Data ke dalam SPSS}

\section{Pentingnya Pengisian Data}

Pengisian data pada program SPSS dilakukan setelah seluruh data fisik pada lembar wawancara diperiksa dan diverifikasi oleh Tim Pemantau. Pengisian data merupakan tahap awal dalam pengolahan data. Pada prinsipnya, program statistik lain juga dapat digunakan, kami menggunakan SPSS di sini sebagai contoh. Untuk latihan, silakan men-download file-file berikut dari: http://www.cifor.cgiar.org/manual:

\section{Download 1. Rumahtangga.sav}

Download 2. Indeksrumahtangga.sav

Download 3. Indeksrumahtanggafinal.sav

Seluruh kerja berat dari ratusan orang pendata desa dan Tim Pemantau akan sia-sia jika ada banyak kesalahan pada tahap pengisian data. Kesalahan pada tahap ini akan berakibat pada kesalahan dalam analisis dan pengambilan kesimpulan serta rekomendasi.

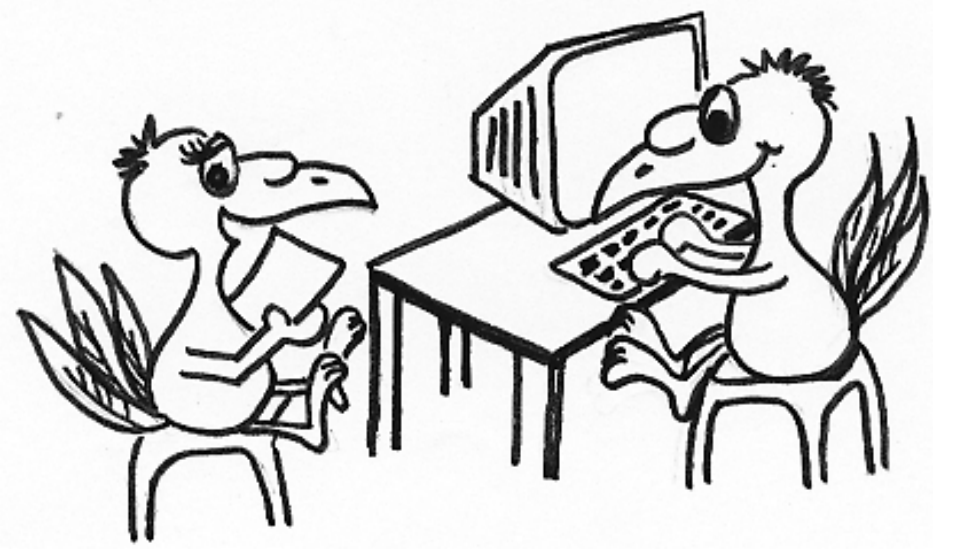

Dampak akhir dari kesalahan akan fatal karena akan menyebabkan Tim Pemantau memberikan rekomendasi yang salah pada pimpinan daerah, atau menyebabkan kesalahan pada penghitungan angka kemiskinan.

\section{Perekrutan dan Pengaturan Kerja}

Kriteria untuk Menjadi Operator Pemasukan (entry) Data:

- Kesediaan untuk bekerja setidaknya empat jam sehari, jika kurang, maka sewa komputer menjadi tidak efisien.

- Kemampuan menjalankan komputer menggunakan sistem operasi Windows, tidak perlu tingkat ahli.

Mengingat satu kelompok kerja harus terdiri dari dua orang, satu pengetik dan satu pembaca, jadwal kerja masing-masing anggota kelompok (2 orang) harus sama. Jika jadwal kerja mereka berlainan, maka hanya ada satu orang yang akan bekerja. Hal ini akan berpotensi timbulnya kesalahan dalam pemasukan data.

Jadwal kerja harus diatur sedemikian rupa sehingga komputer dapat digunakan secara efektif. Harus diingat bahwa komputer disewa per hari sehingga harus dimanfaatkan sebaik mungkin. Jika ada banyak orang yang tidak dapat bekerja penuh, misalnya 4 (empat) jam kerja per hari, maka lebih baik untuk merekrut lebih banyak tim sehingga dapat digunakan sistem giliran (shift).

\section{Menyiapkan Komputer dan Tempat Kerja}

Pemasukan data akan lebih baik jika dilakukan di satu tempat. $\mathrm{Hal}$ ini akan lebih menjamin pengaturan kerja yang lebih baik dan mengurangi kemungkinan hilangnya lembar wawancara. Sebelum petugas pemasukan data mulai bekerja, komputer harus sudah dipersiapkan: (1) program SPSS sudah harus dipasang dalam komputer; dan (2) lembar kerja SPSS sudah disiapkan dalam direktori C: $\backslash$ Data Entry. 
Hal-hal berikut juga perlu untuk diperhatikan:

1. Pastikan spesifikasi komputer yang digunakan sesuai dengan tuntutan untuk instalasi program SPSS.

2. Pastikan komputer dalam keadaan baik, termasuk fasilitas port USB agar data dapat dicopy dengan mudah

3. Hapus instalasi perangkat lunak musik - cukup satu komputer yang memiliki program pemutar musik (jika benar-benar diperlukan saja).

4. Pastikan penerangan dalam ruangan memadai, termasuk jika petugas harus bekerja pada malam hari.

6. Sediakan satu kotak kardus per komputer untuk menaruh lembar wawancara yang sudah selesai dimasukkan.

\section{Membuka Program SPSS}

1. Cari SPSS dalam "Program Files". Jika komputer Anda memiliki "ikon" jalan pintas (shortcut) untuk program SPSS pada desktop, cukup temukan "ikon" ini lalu klik dua kali untuk membuka aplikasi SPSS (lihat Gambar 7.1).

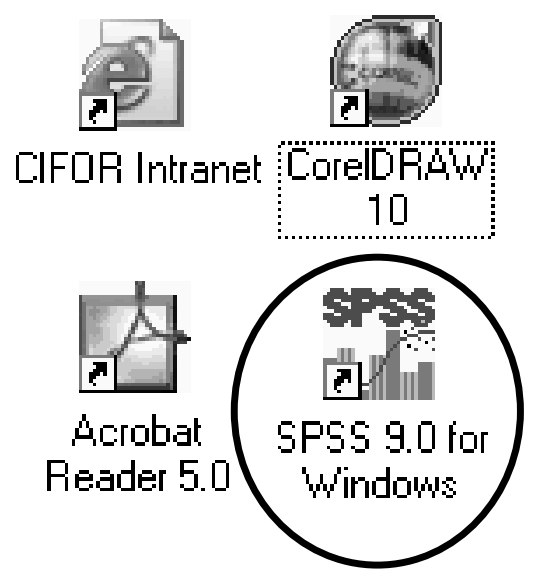

Gambar 7.1. Shortcut untuk SPSS
2. Jika Anda belum pernah membuka aplikasi ini sebelumnya, Anda akan melihat kotak dialog SPSS for Windows. Tutuplah kotak dialog ini, lalu klik menu "Open" (lihat Gambar 7.2).

3. Buka file Rumahtangga.sav (diasumsikan Anda sudah men-download data ini, dan sudah mengcopynya ke direktori $C: \backslash$ Data Entry).

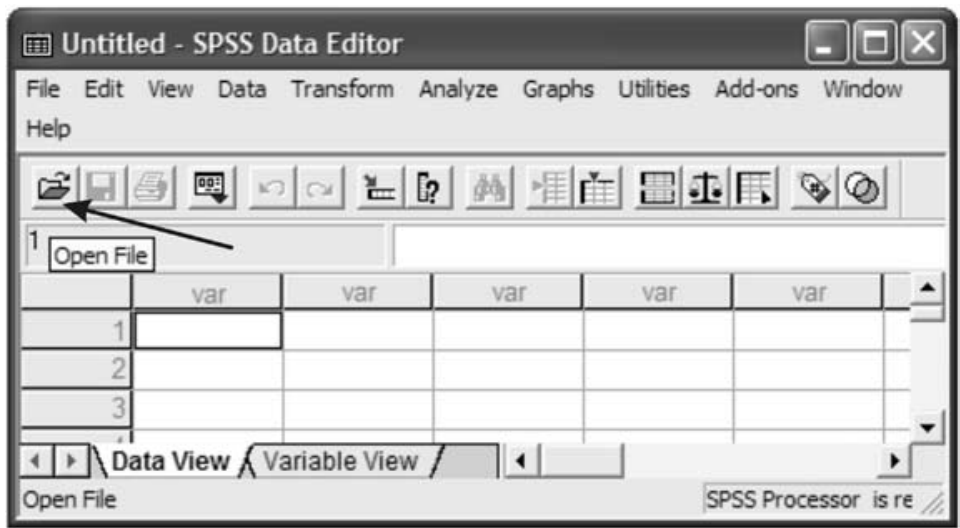

Gambar 7.2. Menu "Open" SPSS

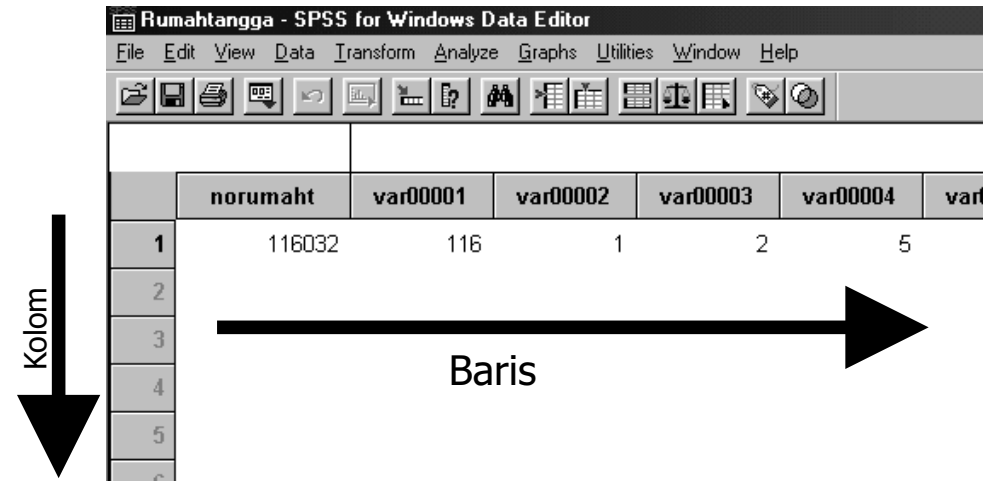

Gambar 7.3. Baris dan kolom dalam SPSS 
Kemudian akan tampak kotak-kotak atau sel-sel yang membentuk kolom dan baris. Dalam bahasa SPSS, kolom tersebut disebut 'variabel,' disingkat 'var.' Sedangkan baris disebut juga 'kasus' yang dalam hal ini berarti responden atau rumah tangga. Dengan demikian, satu baris atau satu kasus merupakan satu kumpulan data untuk satu rumah tangga. Baris dilengkapi dengan nomor urut dari atas ke bawah (lihat gambar 7.3).

\section{Memasukkan Data}

\section{Aturan Dasar}

1. Dalam mengisi data, Anda harus mulai dari variabel yang paling kiri, yaitu nomor rumah tangga, dan dilanjutkan ke kanan secara berurutan (lihat Gambar 7.3).
2. Nomor rumah tangga ada pada lembar wawancara halaman pertama di bagian pojok kanan atas.

3. Urutan variabel pada lembar SPSS di komputer sesuai dengan urutan variabel pada lembar wawancara (lihat Gambar 7.4).

4. Jika Anda ingin menghubungkan data ini dengan data kependudukan, misalnya dari Disdukcapil, maka nama kepala rumah tangga dan nama responden harus diketik pada lembar kerja SPSS.

5. Pengetikan harus dilakukan oleh dua orang. Satu orang mendiktekan, dan satu orang lagi mengetik jawaban untuk setiap variabel.

6. Setiap selesai mengetik tiga halaman lembar wawancara, Anda harus berhenti dan memeriksa apakah informasi yang Anda masukkan sama dengan yang ada di lembar wawancara. Hal ini penting untuk menghindari kesalahan.

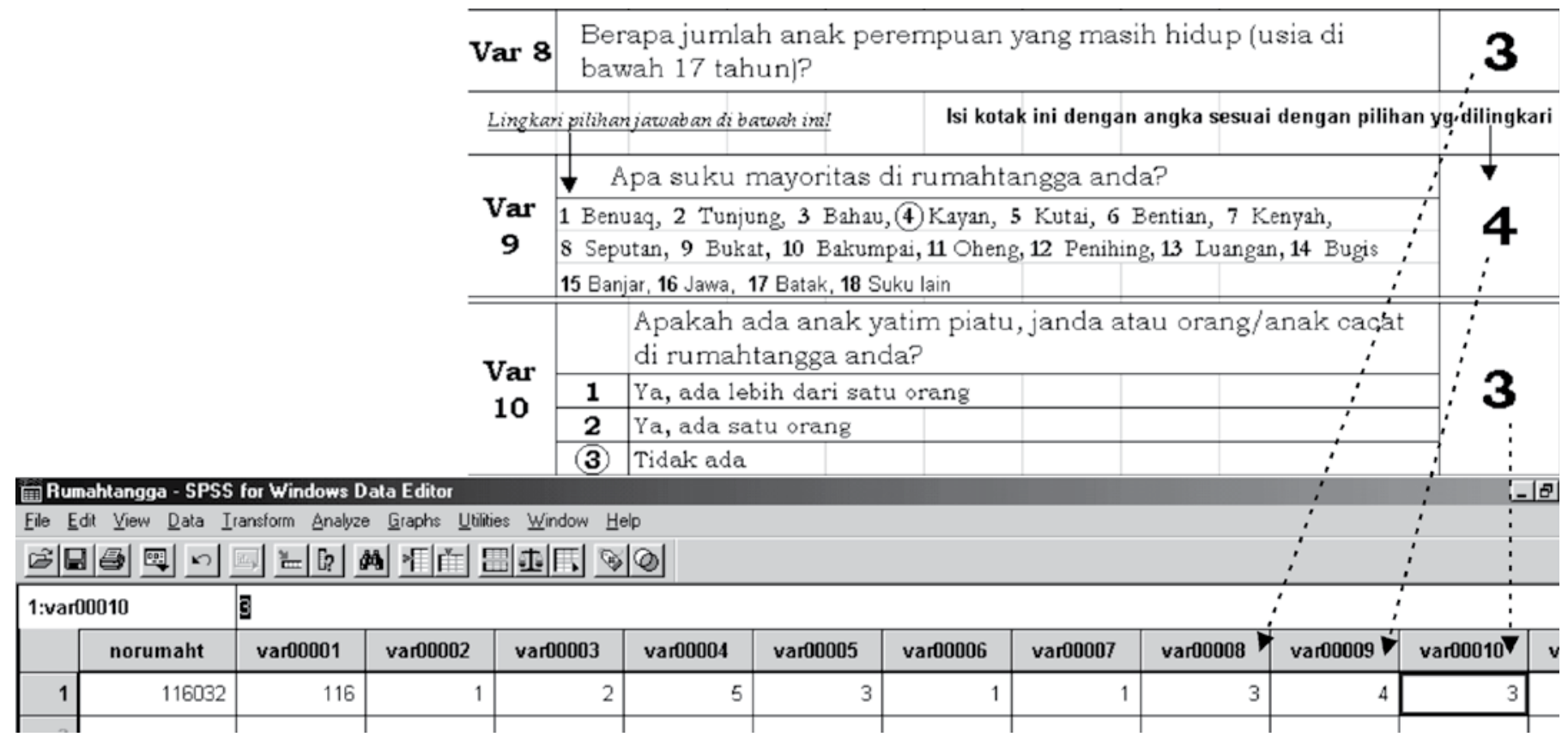

Gambar 7.4. Memindahkan data dari lembar wawancara ke lembar kerja SPSS 
7. Satu eksemplar lembar wawancara menempati satu baris (kasus) pada lembar kerja SPSS.

\section{Mengetik dan mengoreksi}

- Untuk mengetik angka, tekan tombol angka seperti biasa.

- Untuk berpindah ke variabel berikutnya, gunakan tombol panah kanan.

- Untuk mengoreksi atau mengganti ketikan yang salah, arahkan "kursor" pada kotak/sel yang dimaksud dan ketikkan angka yang benar.

- Untuk menghapus gunakan tombol "DEL".

- Untuk mulai mengisi kasus (lembar wawancara) baru, gerakkan "kursor" ke baris di bawahnya dan ke arah kiri sampai variabel paling kiri terlihat. Lalu gerakkan "kursor" ke nomor sel rumah tangga.

- Cara lain untuk mulai mengisi kasus baru adalah sebagai berikut: bila Anda sampai di akhir pengisian, tekan tombol "Home" pada keyboard komputer atau klik sel paling kiri, lalu pindahlah ke sel baru.

Menghapus
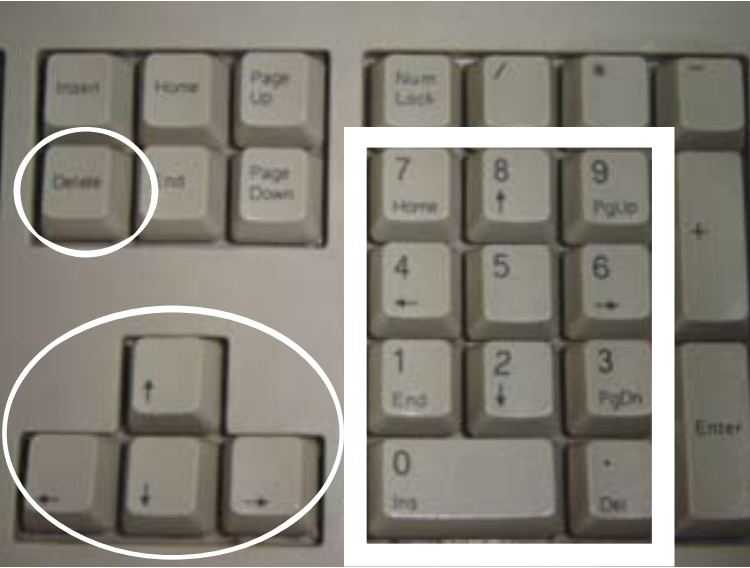

Menggeser kursor

Mengetik angka

Gambar 7.5. Tombol-tombol keyboard dan fungsinya

\section{Menyimpan dan Menutup}

- Untuk menghindari kemungkinan hilangnya data, hal yang penting adalah menyimpan data setiap kali menyelesaikan satu lembar wawancara.

- Menyimpan file dapat dilakukan dengan mudah yaitu dengan mengklik "ikon" save (gambar disket kecil di sebelah kiri atas, "ikon" kedua dari kiri), atau dengan mengklik "File" lalu pilih "Save" (Gambar 7.6).

- Jika Anda ingin beristirahat sejenak atau pulang sehingga harus meninggalkan komputer, tutuplah lembar kerja SPSS Anda.

- Untuk menutupnya, klik "File" dan pilih "Exit," atau tekan tanda silang di sudut kanan atas. Sebelum ditutup, pastikan pekerjaan sudah disimpan.

- Data rumah tangga setiap desa harus disimpan pada file yang berbeda, satu file satu desa. File harus dinamai dengan nama desa, misalnya, untuk Desa Durian, nama filenya harus Durian. File setiap desa harus disediakan terlebih dahulu oleh Tim Pemantau yang menjadi pengawas dari petugas pemasukan data.

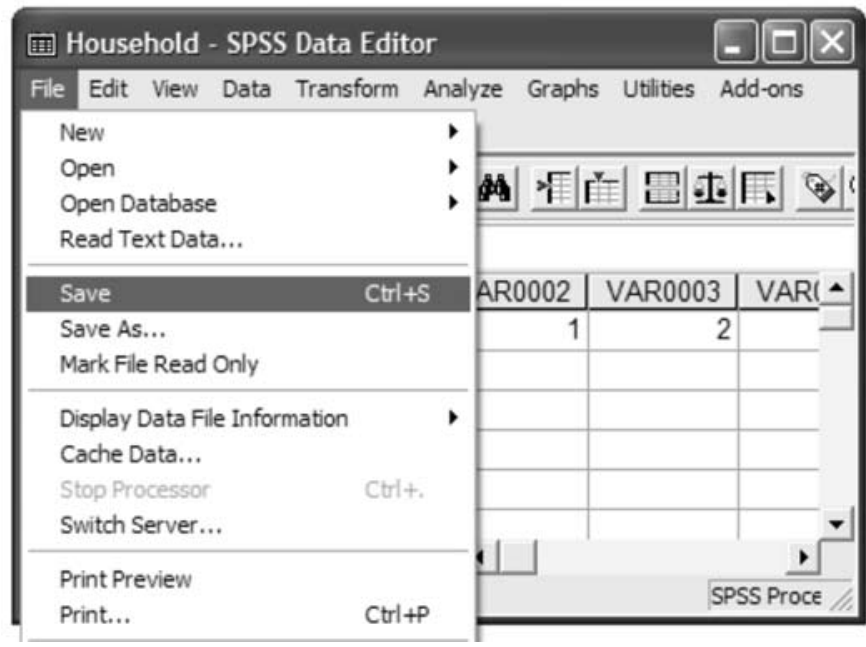

Gambar 7.6. Menyimpan pekerjaan 


\section{Memeriksa Hasil}

Untuk memastikan bahwa data dimasukkan dengan benar, Tim Pemantau harus melakukan pemeriksaan. Sebanyak 15 persen dari jumlah lembar wawancara dari setiap desa akan diperiksa.

\section{Contoh:}

Jika jumlah lembar wawancara rumah tangga Desa Nenas adalah 46 eksemplar, maka pemeriksaan harus dilakukan pada 15 persen dari 46 yaitu 7 (tujuh) eksemplar (dibulatkan dari 6,9). Ketujuh lembar wawancara ini dipilih secara acak. Untuk mudahnya, cukup palingkan wajah dan ambil tujuh lembar dari tumpukan.
Setelah memilih ketujuh lembar wawancara tersebut, lakukan langkah berikut untuk memeriksanya:

- Carilah nomor rumah tangga pada lembar kerja SPSS di komputer yang sesuai dengan nomor pada lembar wawancara.

- Setelah ditemukan, periksa data yang dimasukkan satu per satu untuk setiap variabel. Pastikan data pada komputer sesuai dengan jawaban pada lembar wawancara.

- Jika ada kesalahan, walaupun hanya satu entry, maka petugas pemasukan data harus memeriksa seluruh pekerjaannya kembali. Setelah pemeriksaan dilakukan, Tim Pemantau dapat melanjutkan pemeriksaan lain dengan cara semula (memilih 15 persen secara acak), demikian selanjutnya sampai data dinyatakan benar.

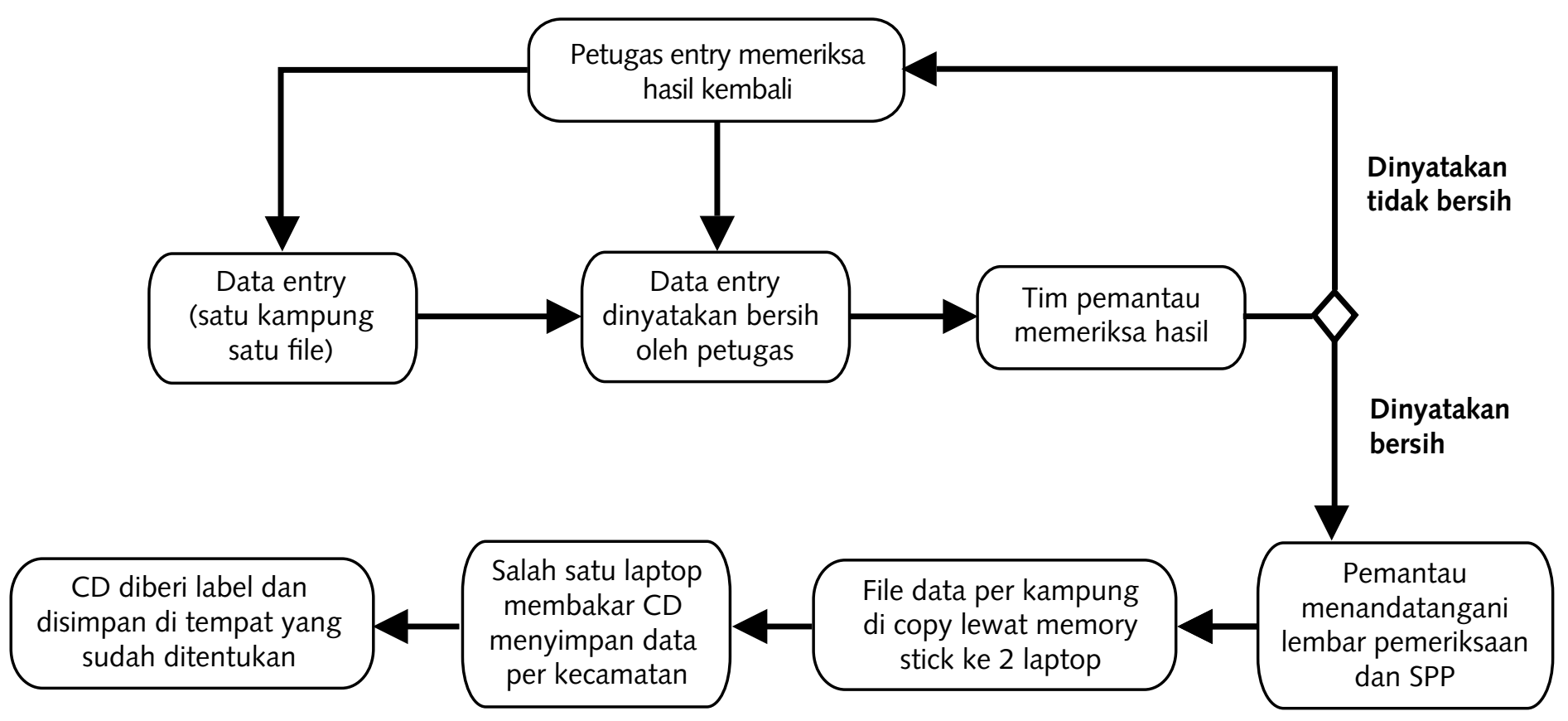

Gambar 7.7. Diagram proses pemasukan data 
- Jika seluruh data benar, maka Tim Pemantau yang bertanggung jawab memeriksa dapat mengesahkan hasil pemasukan data dengan menandatangani lembar pernyataan bersih.

- Surat Perintah Pembayaran (SPP) sekarang dapat ditandatangani.

- Salin data yang sudah diverifikasi tersebut ke dalam memory stick, simpan ke dalam komputer yang telah ditetapkan sebagai tempat menyimpan data yang sudah diverifikasi.

\section{Penyelesaian Proses Pengisian Data}

Petugas yang bertanggung jawab atas data harus mengatur file-file tersebut per kecamatan, kemudian menyimpannya ke dalam CD (compact disk). CD ini harus diberi label dan disimpan di tempat aman yang telah ditentukan.

Seluruh proses ini dirangkum dalam Gambar 7.7. 

Penghitungan Indeks 


\section{Penghitungan Indeks}

Indeks kemiskinan dihitung untuk:

1. Mengetahui tingkat kemiskinan pada tingkat rumah tangga, desa, kecamatan, dan kabupaten/kota

2. Mendiagnosis permasalahan wilayah

3. Mendiagnosis permasalahan sektoral

4. Membantu penyusunan strategi intervensi dalam penanggulangan kemiskinan

5. Membantu peningkatan akurasi penentuan sasaran program bantuan kemiskinan.

Meskipun indeks ini dihitung di tingkat rumah tangga, indeks ini harus dijumlahkan di tingkat desa atau kecamatan karena pendataan ini tidak mencakup seluruh rumah tangga pada desa tertentu.

Contoh dari Kutai Barat menunjukkan bahwa di sejumlah desa ada beberapa rumah tangga dengan informasi variabel konteks yang kosong. Dalam kasus semacam ini, indeks tidak dapat dihitung dengan benar. Jika jumlah rumah tangga yang memberikan jawaban untuk variabel-variabel pada suatu lingkungan tertentu kurang dari lima, maka tidak ada indeks yang dapat dihitung untuk lingkungan tersebut di tingkat desa. Jika hal ini terjadi, indeks lingkungan untuk desa

Tabel 8.1. Kisaran nilai indeks kesehatan

\begin{tabular}{|l|l|c|c|}
\hline \multicolumn{1}{|c|}{ Indikator } & Nilai & Min & Maks \\
\hline Kekurangan makanan (Var 12) & 1,3 & 1 & 3 \\
\hline Air minum (Var 13) & $1,2,3$ & 1 & 3 \\
\hline Akses pada layanan kesehatan (Var 14) & $1,2,3$ & 1 & 3 \\
\hline Total & & 3 & 9 \\
\hline
\end{tabular}

tersebut akan diganti dengan indeks lingkungan rata-rata pada kecamatan yang bersangkutan.

\section{Penghitungan Indeks untuk Kesejahteraan Inti}

\section{Tabel Kisaran Nilai}

Tabel kisaran nilai sangat penting untuk memudahkan perhitungan. Tabel ini dibuat berdasarkan kisaran nilai pada lembar wawancara.

Tabel ini dibuat dengan menjumlahkan nilai minimal dan nilai maksimal dari seluruh indikator (variabel).

\section{Contoh:}

Lingkungan kesehatan terdiri dari tiga indikator: Var 12, Var 13 dan Var 14 (Tabel 8.1).

Lakukan langkah yang sama untuk indeks-indeks lainnya. Lihat lembar wawancara pada Lampiran 1 untuk rujukan. Setelah selesai menghitung, bandingkan hasilnya dengan Lampiran 2.

\section{Contoh menghitung indeks kesehatan}

Perhatikan Tabel 8.1., terlihat bahwa indeks kesehatan terdiri dari Var 12, Var 13 dan Var 14, nilai minimal adalah 3 , sementara nilai maksimal adalah 8 . Berdasarkan rumus penghitungan indeks seperti telah dijelaskan di muka (Konsep Pemantauan), rumus indeks kesehatan adalah:

\begin{tabular}{|c|c|c|c|}
\hline \multirow{2}{*}{$\begin{array}{c}\text { Indeks } \\
\text { kesehatan }\end{array}$} & $\begin{array}{c}\text { Jumlah skor yang } \\
\text { diperoleh }\end{array}$ & - & $\begin{array}{c}\text { Jumlah } \\
\text { skor minimum }\end{array}$ \\
\hline & $\begin{array}{c}\text { Jumlah } \\
\text { skor maksimum }\end{array}$ & - & $\begin{array}{c}\text { Jumlah } \\
\text { skor minimum }\end{array}$ \\
\hline
\end{tabular}


Contoh dari sebuah rumah tangga di desa Pisang Rumah tangga nomor 220040001 menjawab variabel kesehatan sebagai berikut:

\begin{tabular}{|l|c|c|}
\hline \multicolumn{1}{|c|}{ Variabel } & Jawaban & Nilai/Skor \\
\hline Kekurangan makanan (Var 12) & Ya & 1 \\
\hline Air minum (Var 13) & Ya, selalu & 3 \\
\hline Akses pada layanan kesehatan (Var 14) & Ya, selalu & 3 \\
\hline
\end{tabular}

Jumlah skor yang diperoleh $=1+3+3=7$

Jumlah skor maksimum $=3+3+3=9$

Jumlah skor minimum $=1+1+1=3$

$$
\text { Indeks kesehatan } \frac{7-3}{9-3} \times 100=66,67
$$

Penghitungan ini untuk satu rumah tangga saja. Bagaimana penghitungan indeks kesehatan untuk seluruh 634

Tabel 8.2. Menu "Compute" untuk indeks kesehatan

\begin{tabular}{|l|l|l|}
\hline \multicolumn{1}{|c|}{ Kolom } & \multicolumn{1}{|c|}{ Maksud } & Yang harus dilakukan \\
\hline $\begin{array}{l}\text { "Target } \\
\text { Variable" }\end{array}$ & $\begin{array}{l}\text { Variabel yang akan menjadi } \\
\text { hasil penghitungan. Anda } \\
\text { dapat mengetikkan variabel } \\
\text { yang sudah ada atau } \\
\text { membuat variabel baru }\end{array}$ & $\begin{array}{l}\text { Buat variabel } \\
\text { baru yang disebut } \\
\text { 'Kesehatan' }\end{array}$ \\
\hline $\begin{array}{l}\text { "Type \& } \\
\text { Label" }\end{array}$ & $\begin{array}{l}\text { Jenis data yang Anda } \\
\text { inginkan (numeric untuk } \\
\text { nomor, string untuk } \\
\text { campuran nomor dan huruf). } \\
\text { Label adalah penjelasan } \\
\text { lengkap variabel ini }\end{array}$ & $\begin{array}{l}\text { Pilih "Numeric," pada } \\
\text { label ketik: 'Indeks } \\
\text { Kesehatan var12, } \\
\text { var13, var14' }\end{array}$ \\
\hline "Numeric & $\begin{array}{l}\text { Rumus yang digunakan } \\
\text { Expression" }\end{array}$ & $\begin{array}{l}\text { (var00012 + } \\
\text { var00013 + var00014 } \\
-3) /(9-3) * 100\end{array}$ \\
\hline "//If" & $\begin{array}{l}\text { Syarat untuk penghitungan } \\
\text { 'The calculation is valid if...' }\end{array}$ & Abaikan \\
\hline
\end{tabular}

rumah tangga yang Anda miliki pada seluruh set data (Rumahtangga.sav)? Jelas Anda perlu program komputer untuk memudahkan penghitungan. SPSS adalah salah satu program komputer yang dapat digunakan.

Pada program SPSS, Anda dapat menggunakan menu "Compute" (lihat Gambar 8.1.)

Tabel 8.2 menjelaskan konsep menu "Compute" dalam penghitungan indeks kesehatan.

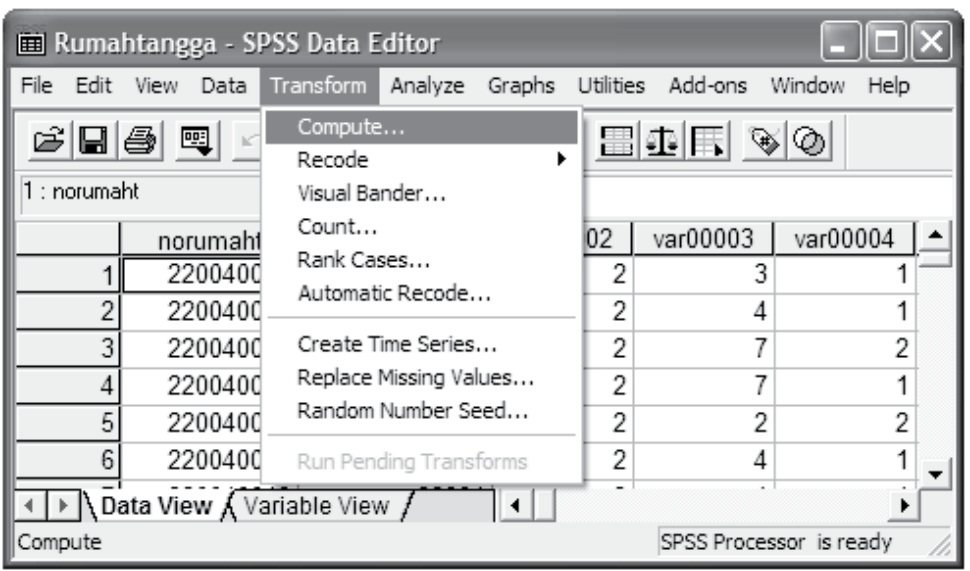

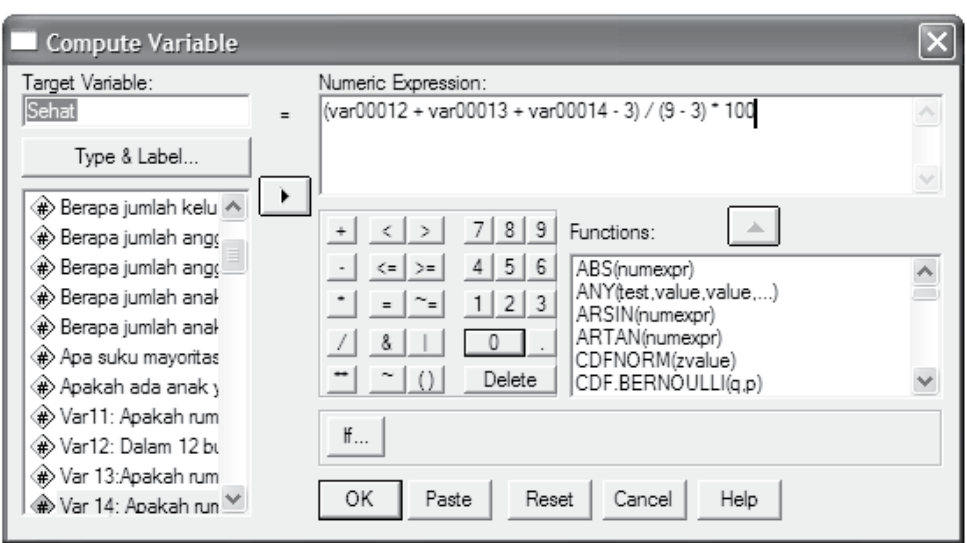

Gambar 8.1. Menu "Compute" SPSS 
Jika penghitungan Anda benar, Anda akan melihat variabel baru dengan nama 'Kesehatan.' Variabel ini ada di kolom paling kanan dengan barisan angka-angka di bawahnya. Angka-angka ini adalah indeks kesehatan untuk setiap kasus (rumah tangga). Lakukan hal yang sama untuk indeksindeks lain, yaitu kesejahteraan subjektif, pengetahuan, dan kekayaan materi. Lihat pengelompokan indikator pada Lampiran 2 untuk rujukan.

Setelah selesai melakukan penghitungan, bandingkan hasilnya dengan set data 'Indeksrumahtangga.sav' pada Download 2.

Yang sudah Anda lakukan sejauh ini baru untuk indeks di tingkat rumah tangga. Jika Anda ingin mengetahui indeks inti pada tingkat desa, kecamatan atau kabupaten/kota, Anda harus menghitung rata-ratanya. Langkah ini dijelaskan secara rinci pada Modul 9.

\section{Penghitungan Indeks untuk Lingkungan Pendukung (Konteks)}

\section{Menghitung Indeks}

Rumus indeks lingkungan konteks sama dengan rumus untuk indeks lingkungan inti.

Contoh menghitung indeks lingkungan sosial Lampiran 2 menunjukkan bahwa indeks lingkungan sosial terdiri dari Var 30, Var 31 dan Var 32, nilai minimal adalah 3, sementara nilai maksimal adalah 8 . Berdasarkan rumus penghitungan indeks seperti telah dijelaskan di muka (Konsep Pemantauan), rumus indeks kesehatan adalah:

\begin{tabular}{|c|c|c|}
\hline \multirow{2}{*}{$\begin{array}{l}\text { Indeks } \\
\text { lingkungan } \\
\text { sosial }\end{array}$} & $\begin{array}{l}\text { Jumlah skor yang } \\
\text { diperoleh }\end{array}$ & $\begin{array}{r}\text { Ju } \\
-\quad \text { skor } n\end{array}$ \\
\hline & $\begin{array}{r}\text { Ju } \\
\text { skor m }\end{array}$ & $\begin{array}{r}\text { Ju } \\
-\quad \text { skor } n\end{array}$ \\
\hline
\end{tabular}

Contoh dari sebuah rumah tangga di desa Pisang (Lihat set data 'Rumahtangga.sav' pada Download 1.) Rumah tangga nomor 220040001 menjawab variabel sosial sebagai berikut:

\begin{tabular}{|l|l|c|}
\hline \multicolumn{1}{|c|}{ Variabel } & \multicolumn{1}{c|}{ Jawaban } & Nilai/Skor \\
\hline Tingkat gotong-royong (Var 30) & Cukup bersedia & 2 \\
\hline Tingkat rasa saling percaya (Var 31) & Sedang & 2 \\
\hline Frekuensi konflik (Var 32) & Jarang terjadi & 3 \\
\hline
\end{tabular}

Jumlah skor yang diperoleh $=2+2+3=7$

Jumlah skor maksimum $=3+3+3=9$

Jumlah skor minimum $=1+1+1=3$

$$
\text { Indeks lingkungan sosial } \frac{7-3}{9-3} \times 100=66,67
$$

Anda dapat menggunakan menu "Compute" lagi untuk menghitung indeks untuk seluruh data seperti dijelaskan pada Gambar 8.1.

Tabel 8.3 menjelaskan isi menu "Compute" untuk menghitung indeks lingkungan sosial (gunakan set data 'Rumahtangga.sav' pada Download 1).

Jika Anda melakukannya dengan benar, variabel baru dengan nama 'Sosial' berikut kolom angka-angka di bawahnya akan muncul.

Sekarang, lakukan yang sama untuk lingkungan konteks lainnya (alam, ekonomi, politik, infrastruktur dan pelayanan). Lihat Lampiran 1 dan 2 untuk rujukan. Bandingkan hasil yang Anda peroleh dengan set data 'Indeksrumahtangga.sav' pada Download 2. 
Tabel 8.3. Isi menu "Compute" untuk indeks lingkungan sosial

\begin{tabular}{|c|c|c|}
\hline Kolom & Maksud & $\begin{array}{l}\text { Yang harus } \\
\text { dilakukan }\end{array}$ \\
\hline $\begin{array}{l}\text { "Target } \\
\text { Variable" }\end{array}$ & $\begin{array}{l}\text { Variabel yang akan menjadi } \\
\text { hasil penghitungan. Anda } \\
\text { dapat mengetikkan variabel } \\
\text { yang sudah ada atau membuat } \\
\text { variabel baru }\end{array}$ & $\begin{array}{l}\text { Buatlah variabel } \\
\text { baru dengan } \\
\text { nama 'Sosial' }\end{array}$ \\
\hline $\begin{array}{l}\text { "Type \& } \\
\text { Label" }\end{array}$ & $\begin{array}{l}\text { Jenis data yang Anda inginkan } \\
\text { (numeric untuk nomor, string } \\
\text { untuk campuran nomor dan } \\
\text { huruf). Label adalah penjelasan } \\
\text { lengkap variabel ini }\end{array}$ & $\begin{array}{l}\text { Pilih "Numeric", } \\
\text { pada label ketik } \\
\text { ‘Indeks Sosial } \\
\text { var12, var13, } \\
\text { var14' }\end{array}$ \\
\hline $\begin{array}{l}\text { "Numeric } \\
\text { Expression" }\end{array}$ & $\begin{array}{l}\text { Rumus yang digunakan untuk } \\
\text { penghitungan }\end{array}$ & $\begin{array}{l}(\text { var00030 + } \\
\text { var00031 + } \\
\text { var00032-3)/ } \\
(9-3) * 100\end{array}$ \\
\hline "//If" & $\begin{array}{l}\text { Syarat untuk penghitungan } \\
\text { 'The calculation is valid if...' }\end{array}$ & Abaikan \\
\hline
\end{tabular}

\section{Memeriksa Frekuensi "Valid" dan "Missing"}

Untuk memastikan keterwakilan pandangan warga desa, jumlah responden yang memberikan jawaban harus tidak boleh kurang dari lima. Artinya, setidaknya harus ada lima orang yang menjawab seluruh variabel dalam lingkungan konteks tertentu. Jika ada responden yang melewatkan satu variabel sekalipun, responden ini tidak akan memberi nilai/skor apapun pada indeks yang bersangkutan ('system missing').

Pada SPSS, responden yang menjawab disebut "valid", sedangkan responden yang tidak memberi jawaban disebut "missing".

Kita dapat menggunakan menu "Frequencies" (Gambar 8.2,
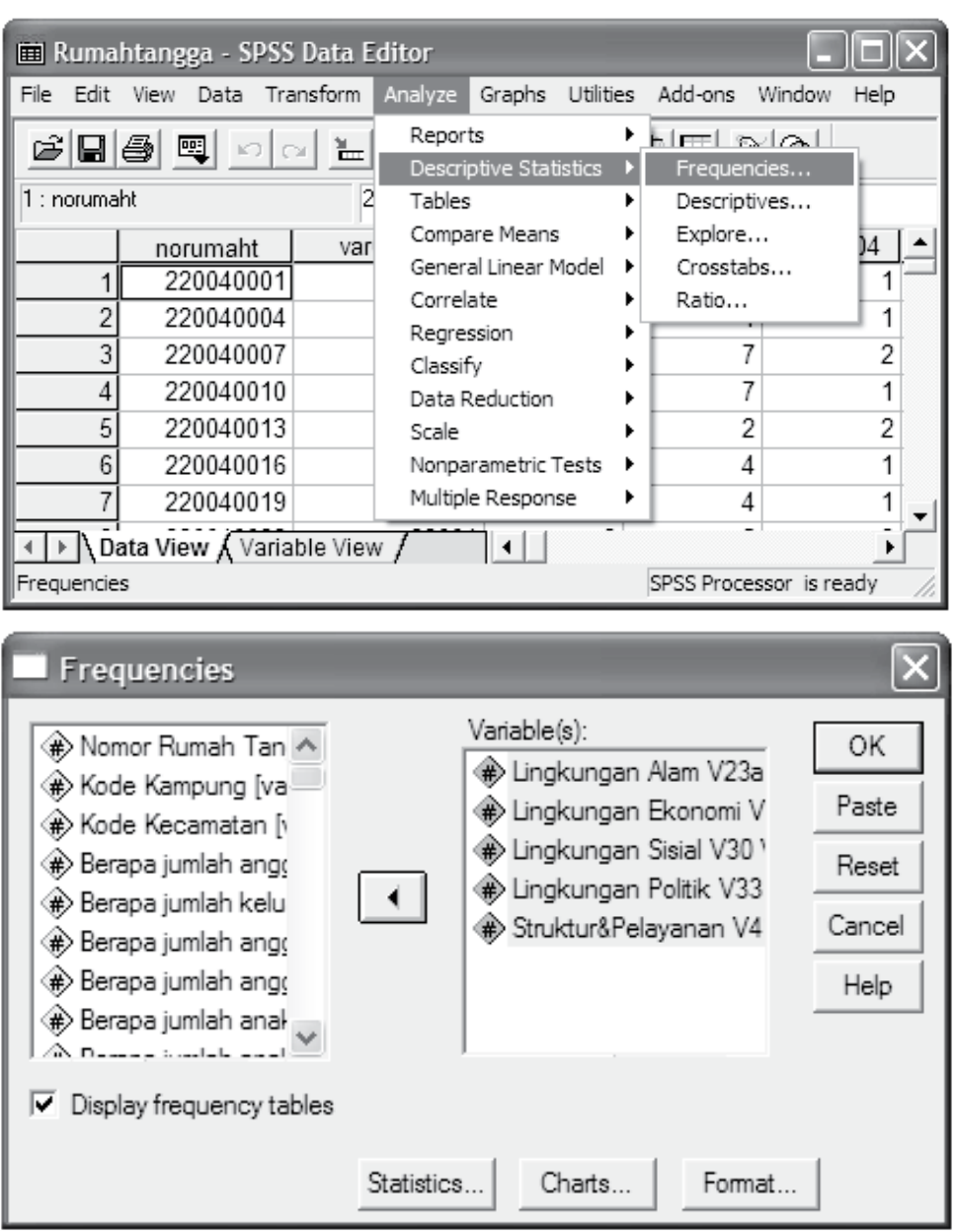

Gambar 8.2. Menu "Frequencies"

Tabel 8.4) untuk menghitung responden yang "valid"dan "missing". Menu "Frequencies" dapat diakses dengan masuk ke:

"Analyse" >> "Descriptive Statistic" >> "Frequencies"

Anda akan menemukan beberapa tabel pada file output. 
Tabel 8.4. Isi menu "Frequencies"

\begin{tabular}{|l|l|l|}
\hline \multicolumn{1}{|c|}{ Kolom } & \multicolumn{1}{|c|}{ Maksud } & \multicolumn{1}{|c|}{ Yang harus dilakukan } \\
\hline "Variable(s)" & $\begin{array}{l}\text { Variabel yang akan } \\
\text { dianalisis frekuensi }\end{array}$ & $\begin{array}{l}\text { Seluruh indeks konteks } \\
\text { (alam, ekonomi, sosial, } \\
\text { politik, infrastruktur dan } \\
\text { pelayanan) }\end{array}$ \\
\hline "Statistics" & $\begin{array}{l}\text { Analisis statistik tambahan } \\
\text { lain yang Anda perlukan } \\
\text { selain frekuensi (Mean) }\end{array}$ & $\begin{array}{l}\text { Tidak perlu ada analisis } \\
\text { tambahan (abaikan) }\end{array}$ \\
\hline "Charts" & $\begin{array}{l}\text { Jenis grafik yang Anda } \\
\text { inginkan, nilai yang akan } \\
\text { digunakan (frekuensi atau } \\
\text { persentase) }\end{array}$ & Abaikan \\
\hline "Format" & $\begin{array}{l}\text { Format urutan data atau } \\
\text { multi variabel }\end{array}$ & Abaikan \\
\hline
\end{tabular}

Anda hanya perlu memeriksa tabel "Statistic", yang ada di bagian atas file output setelah "Note". Tabel "Statistic" menunjukkan jumlah responden dengan jawaban yang "valid" dan jumlah yang "missing". Jika Anda melakukannya dengan benar, Anda akan melihat bahwa seluruh indeks lingkungan tidak ada yang bermasalah kecuali untuk indeks alam. Indeks alam ini memiliki lebih banyak entry yang "missing" daripada yang "valid".

Untuk mengetahui distribusi data per desa, Anda perlu melakukan analisis "Frequency" lagi. Kali ini, Anda perlu menggunakan menu "Split File" selain menu "Frequencies" agar dapat melakukan penghitungan per desa.

Menu "Split File" (Gambar 8.3) berfungsi untuk mengelompokkan hasil analisis berdasarkan variabel tertentu. Dalam hal ini, Anda harus mengelompokkan hasil analisis frekuensi berdasarkan variabel desa. Menu ini dapat diakses dengan masuk ke:

$$
\text { "Data" >> "Split File" }
$$

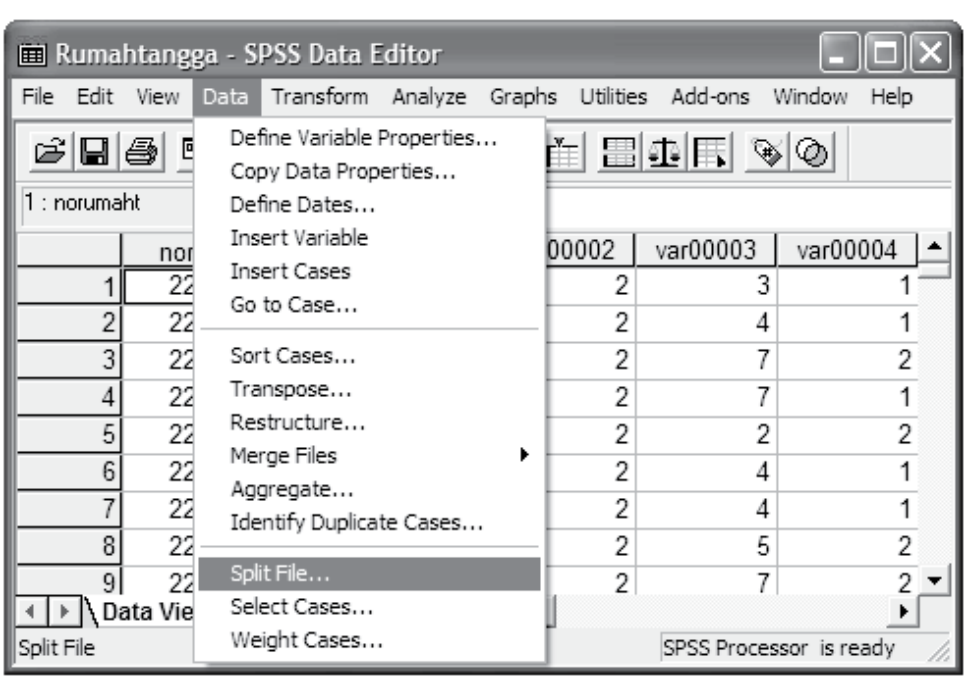

Gambar 8.3. Menu "Split File"

Penjelasan tentang menu "Split File" dapat dilihat pada Tabel 8.5.

Tabel 8.5. Isi menu "Split File"

\begin{tabular}{|l|l|l|}
\hline \multicolumn{1}{|c|}{ Kolom } & \multicolumn{1}{|c|}{ Maksud } & Yang harus dilakukan \\
\hline $\begin{array}{l}\text { "Analyze } \\
\text { all }\end{array}$ & $\begin{array}{l}\text { Menganalisis seluruh } \\
\text { kasus, tidak membuat } \\
\text { pengelompokan }\end{array}$ & $\begin{array}{l}\text { Tidak dipilih karena } \\
\text { Anda perlu melakukan } \\
\text { pengelompokan }\end{array}$ \\
\hline $\begin{array}{l}\text { "Compare } \\
\text { Groups" }\end{array}$ & $\begin{array}{l}\text { Menganalisis kasus dengan } \\
\text { membuat pengelompokan }\end{array}$ & Pilih ini \\
\hline $\begin{array}{l}\text { "Organize } \\
\text { Groups" }\end{array}$ & $\begin{array}{l}\text { Menganalisis kasus dengan } \\
\text { membuat pengelompokan. } \\
\text { Output disajikan menurut } \\
\text { kelompok, satu tabel untuk } \\
\text { setiap kelompok }\end{array}$ & $\begin{array}{l}\text { Tidak dipilih karena } \\
\text { tampilan akan terlalu } \\
\text { rinci }\end{array}$ \\
\hline $\begin{array}{l}\text { "Groups } \\
\text { based on" }\end{array}$ & $\begin{array}{l}\text { Variabel yang akan } \\
\text { menentukan pengelompokan, } \\
\text { misalnya jika Anda } \\
\text { memasukkan variabel kode } \\
\text { desa, maka analisis akan } \\
\text { dilakukan per desa }\end{array}$ & Var00001 (kode desa) \\
\hline
\end{tabular}


Masuklah ke dalam menu "Frequencies" lagi, ikuti langkahlangkah yang dijelaskan pada Gambar 8.2 dan Tabel 8.4. Gunakan indeks 'Alam' sebagai satu-satunya variabel yang dianalisis, karena hanya indeks alam ini saja yang mengandung data yang "missing".

Sekarang Anda dapat melihat laporan frekuensi indeks alam per desa. Cari desa yang memiliki entry kurang dari lima.

Anda akan menemukan Desa Semangka yang tidak memiliki entry (nol), dan Desa Lai yang hanya punya satu entry.

\section{Catatan untuk perlakukan khusus}

Khusus untuk indeks lingkungan alam, kita bagi desa menjadi dua kelompok: (1) desa dengan entry lima atau lebih, dan (2) desa dengan entry kurang dari lima.

Untuk kelompok pertama (seluruh desa, kecuali Desa Lai dan Semangka) seluruh entry akan diganti dengan indeks rata-rata desa, sedangkan untuk kelompok kedua (Lai dan Semangka) kita akan menggunakan rata-rata kecamatan. Secara umum, kita asumsikan bahwa lingkungan alam hampir seluruhnya sama untuk seluruh desa pada kecamatan yang sama (tidak seperti lingkungan ekonomi, sosial, dan politik).

\section{Menghitung Rata-rata Desa dan \\ Kecamatan}

\section{Rata-rata Desa}

Untuk menghitung rata-rata, kita dapat menggunakan menu "Case Summaries" (Gambar 8.4, Tabel 8.6).

$$
\text { "Analyze" >> "Reports ">> "Case Summaries" }
$$

Jika Anda sudah melakukan seluruh langkah dengan benar, Anda akan melihat output seperti pada Tabel 8.7 (dibulatkan).

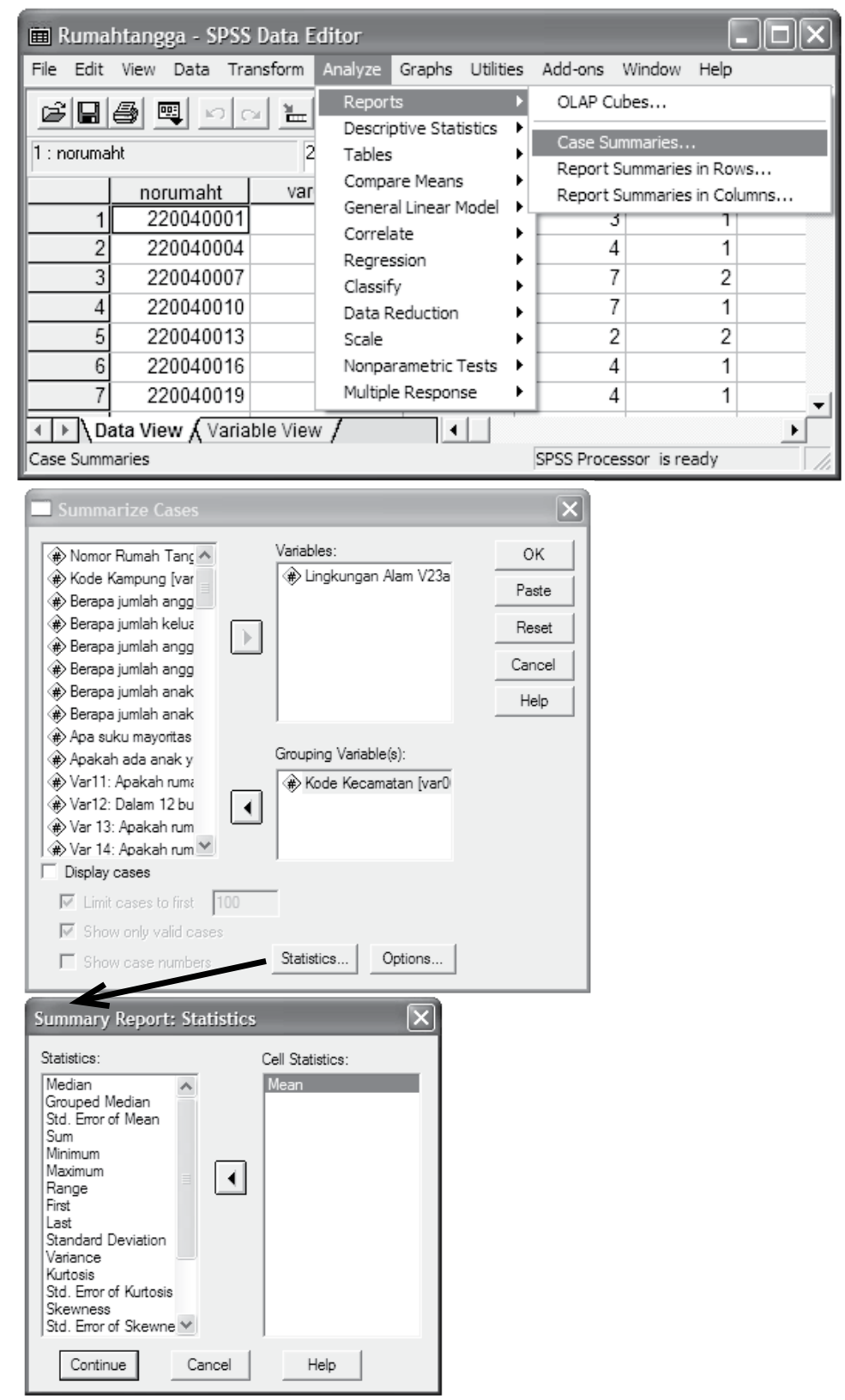

Gambar 8.4. Menu "Case Summaries" 
Meskipun pada tabel terdapat nilai untuk Desa Lai, Anda harus selalu ingat bahwa nilai untuk Desa Lai harus diganti dengan rata-rata kecamatan karena Desa Lai memiliki kurang dari lima entry yang "valid". Desa Semangka tidak muncul karena tidak ada nilai, hal ini terjadi karena seluruh

Tabel 8.6. Isi menu "Case Summaries"

\begin{tabular}{|l|l|l|}
\hline \multicolumn{1}{|c|}{ Kolom } & \multicolumn{1}{|c|}{ Maksud } & \multicolumn{1}{|c|}{$\begin{array}{l}\text { Yang harus } \\
\text { dilakukan }\end{array}$} \\
\hline "Variables" & $\begin{array}{l}\text { Variabel yang ingin Anda analisis } \\
\text { (misal, menghitung rata-rata) }\end{array}$ & Pilih 'Alam' \\
\hline $\begin{array}{l}\text { "Grouping } \\
\text { (Variables)" }\end{array}$ & $\begin{array}{l}\text { Variabel yang ingin Anda gunakan } \\
\text { untuk pengelompokan }\end{array}$ & $\begin{array}{l}\text { Pilih 'Var00001' } \\
\text { (kode desa) }\end{array}$ \\
\hline "Statistic" & $\begin{array}{l}\text { Jenis analisis statistik yang Anda } \\
\text { inginkan (misalnya: mean, sum, std- } \\
\text { dev) }\end{array}$ & $\begin{array}{l}\text { Pilih 'Mean' } \\
\text { (rata-rata) }\end{array}$ \\
\hline $\begin{array}{l}\text { "Option" } \\
\text { "Dampilkan file output (misal, judul } \\
\text { yang Anda inginkan) }\end{array}$ & Abaikan \\
cases" & $\begin{array}{l}\text { Apakah Anda ingin menampilkan } \\
\text { seluruh kasus dengan lengkap }\end{array}$ & $\begin{array}{l}\text { Biarkan tidak } \\
\text { dicentang }\end{array}$ \\
\hline
\end{tabular}

Tabel 8.7. Tabel output rata-rata desa (indeks lingkungan alam)

\begin{tabular}{|l|c|}
\hline \multicolumn{1}{|c|}{ Kode Desa } & Indeks Lingkungan Alam \\
\hline Pisang & 83,65 \\
\hline Salak & 52,50 \\
\hline Melon & 40,04 \\
\hline Jambu & 41,67 \\
\hline Nenas & 61,29 \\
\hline Lai & 87,50 \\
\hline Durian & 72,32 \\
\hline Mangga & 71,43 \\
\hline Jeruk & 18,75 \\
\hline Anggur & 30,88 \\
\hline Sirsak & 54,46 \\
\hline Apel & 38,18 \\
\hline Total & 44,02 \\
\hline
\end{tabular}

respondennya tidak menjawab pertanyaan pada lingkungan alam secara lengkap.

\section{Rata-rata Kecamatan}

Rata-rata kecamatan juga dapat dihitung dengan "Case Summaries".. Lakukan " Case Summaries". sekali lagi seperti dijelaskan pada Gambar 8.4 dan Tabel 8.6, tetapi ganti variabel dari 'Var00001' (kode desa) dengan 'Var00002' (kode kecamatan).

Anda akan mendapatkan output seperti pada Tabel 8.8 (setelah pembulatan).

Tabel 8.8. Tabel output rata-rata kecamatan (indeks lingkungan alam)

\begin{tabular}{|c|c|}
\hline Kode Kecamatan & Indeks Lingkungan Alam \\
\hline Makaranga & 64,77 \\
\hline Bangkirai & 40,04 \\
\hline Meranti & 41,67 \\
\hline Jati & 41,74 \\
\hline Agathis & 45,56 \\
\hline Ulin & 38,18 \\
\hline Total & 44,02 \\
\hline
\end{tabular}

Seperti terlihat pada tabel, indeks lingkungan alam rata-rata di Kecamatan Jati adalah 41,74 (dibulatkan). Inilah yang digunakan untuk Desa Semangka dan Desa Lai.

\section{Mengganti Nilai}

Tabel 8.9 menampilkan hasil kombinasi yang sudah diisi dengan nilai dari seluruh desa dengan Desa Semangka dan Desa Lai menggunakan angka rata-rata kecamatan. 
Tabel 8.9. Kode Desa dan Indeks Alam

\begin{tabular}{|l|l|c|}
\hline \multicolumn{1}{|c|}{ Kode Desa } & \multicolumn{1}{c|}{ Desa } & Indeks Lingkungan Alam \\
\hline 22004 & Pisang & 83,65 \\
\hline 22010 & Salak & 52,50 \\
\hline 32007 & Melon & 40,04 \\
\hline 52003 & Jambu & 41,67 \\
\hline 72004 & Nenas & 61,30 \\
\hline 72007 & Lai & 41,74 \\
\hline 72009 & Durian & 72,32 \\
\hline 72010 & Mangga & 71,43 \\
\hline 72019 & Jeruk & 18,75 \\
\hline 72020 & Semangka & 41,74 \\
\hline 112001 & Anggur & 30,88 \\
\hline 112007 & Sirsak & 54,46 \\
\hline 182002 & Apel & 38,17 \\
\hline
\end{tabular}

Sekarang, gantilah seluruh angka indeks lingkungan alam (untuk rumah tangga) dengan indeks rata-rata (seperti pada Tabel 8.9) Untuk melakukannya, gunakan menu "Recode". Recoding harus dilakukan per desa. Oleh karena itu, recoding harus dilakukan berkali-kali untuk seluruh desa.

Menu "Recode" (Gambar 8.5) dapat ditemukan di:

"Transform" >> "Recode" >> "into Same Variable"

Tabel 8.10 menjelaskan isi menu "Recode" untuk mengambil rata-rata nilai indeks alam.

Periksa kembali recoding yang telah Anda lakukan untuk memastikan seluruh nilai yang dimasukkan sama dengan rata-rata yang tertera pada Tabel 8.9.
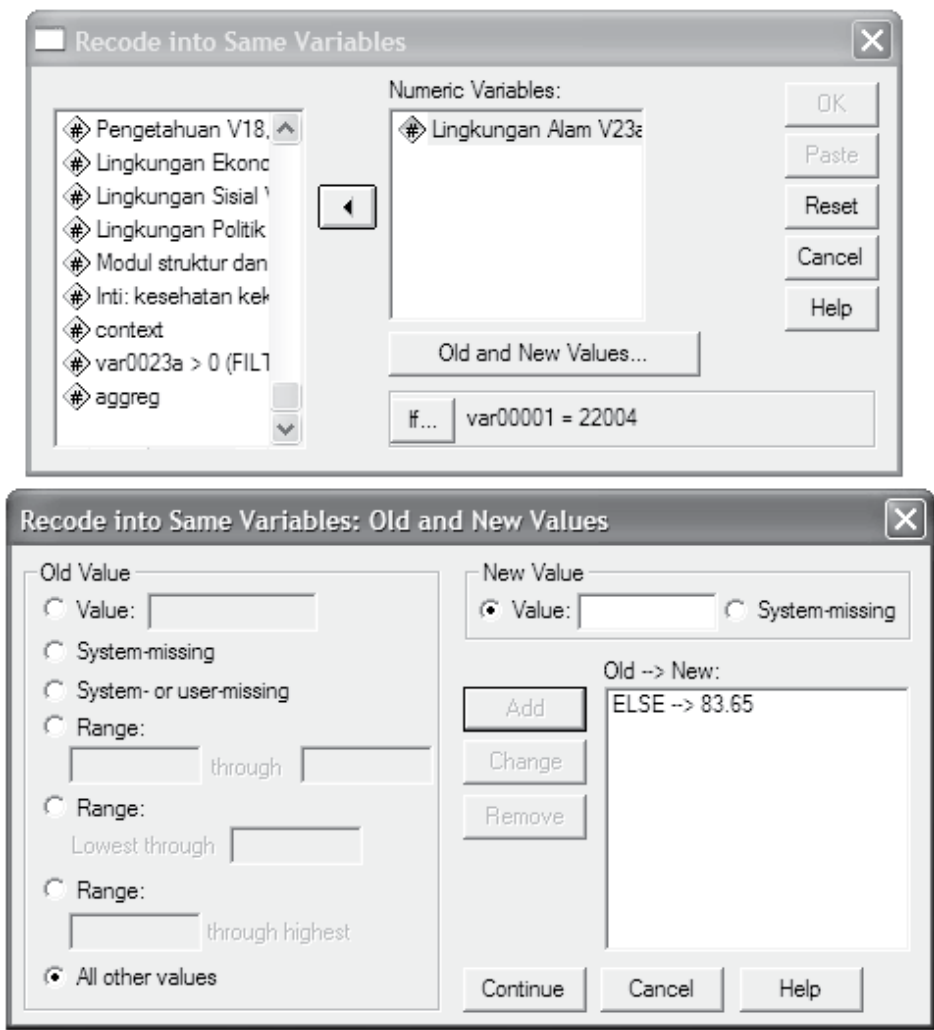

Gambar 8.5. Menu "Recode"

Tabel 8.10. Isi menu "Recode"

\begin{tabular}{|l|l|l|}
\hline \multicolumn{1}{|c|}{ Kolom } & \multicolumn{1}{|c|}{ Maksud } & \multicolumn{1}{c|}{ Yang harus dilakukan } \\
\hline "Variables" & $\begin{array}{l}\text { Variabel mana } \\
\text { yang akan diubah? }\end{array}$ & Pilih 'Alam' \\
\hline "If" & $\begin{array}{l}\text { Apa syarat } \\
\text { perubahan untuk } \\
\text { setiap desa? }\end{array}$ & $\begin{array}{l}\text { Isikan kode desa yang sesuai } \\
\text { pada 'VarO001=...' (misal, } \\
\text { 22004 untuk Desa Pisang) }\end{array}$ \\
\hline $\begin{array}{l}\text { Nilai "Old } \\
\text { and New" }\end{array}$ & $\begin{array}{l}\text { Nilai apa yang } \\
\text { ingin diubah dan } \\
\text { nilai baru apa yang } \\
\text { Anda inginkan? }\end{array}$ & $\begin{array}{l}\text { Nilai lama adalah "all other } \\
\text { values". Nilai baru harus cocok } \\
\text { dengan kode desa pada "If". } \\
\text { Misal, jika kode desa pada "If" } \\
\text { adalah 22004 (Pisang) maka } \\
\text { nilai yang baru adalah 83,65. }\end{array}$ \\
\hline
\end{tabular}




\section{Menghitung Indeks Gabungan untuk Kesejahteraan Inti dan Lingkungan Pendukung (Konteks)}

Indeks gabungan kesejahteraan inti dan lingkungan pendukung (konteks) dapat dihitung dengan menggunakan rumus berikut:

Indeks kesejahteraan inti $=$ (kesehatan + pengetahuan + kekayaan)/3

Indeks konteks $=($ Politik + Ekonomi + Sosial + Alam + Infrastruktur dan pelayanan)/5

Indeks agregat $=$ (Indeks kesejahteraan inti + Indeks konteks)/2

Indeks gabungan ini hanya dapat dihitung jika seluruh indeks dasar telah dihitung. Penghitungannya dapat lebih mudah dilakukan dengan menggunakan menu "Compute" (Tabel 8.11) seperti telah dijelaskan di muka. Anda dapat mengakses menu ini di:
Tabel 8.11. Isi menu 'Compute

\begin{tabular}{|l|l|l|}
\hline \multirow{2}{*}{ Kolom } & \multicolumn{2}{|c|}{ Yang harus dilakukan } \\
\cline { 2 - 3 } & \multicolumn{1}{|c|}{ Kesejahteraan Inti } & \multicolumn{1}{c|}{ Konteks } \\
\hline $\begin{array}{l}\text { "Target } \\
\text { Variable" }\end{array}$ & $\begin{array}{l}\text { Buat variabel baru, } \\
\text { namakan 'Kesejahteraan } \\
\text { Inti' }\end{array}$ & $\begin{array}{l}\text { Buat variabel baru, } \\
\text { namakan 'Konteks' }\end{array}$ \\
\hline $\begin{array}{l}\text { "Type \& } \\
\text { Label" }\end{array}$ & $\begin{array}{l}\text { Tipe: Numeric; } \\
\text { Label: Indeks } \\
\text { Kesejahteraan Inti }\end{array}$ & $\begin{array}{l}\text { Tipe: Numeric; } \\
\text { Label: Indeks Konteks }\end{array}$ \\
\hline $\begin{array}{l}\text { "Numeric } \\
\text { Expression" }\end{array}$ & $\begin{array}{l}\text { (kesehatan + pengetahuan } \\
\text { + kekayaan)/3 }\end{array}$ & $\begin{array}{l}\text { (alam+ekonomi+sosial+ } \\
\text { politik+infrastruktur\& } \\
\text { layanan)/5 }\end{array}$ \\
\hline "If" & Abaikan & Abaikan \\
\hline
\end{tabular}

"Transform" >> "Compute"

Setelah Anda selalu melakukan seluruh penghitungan, bandingkan hasilnya dengan set data 'Indeksrumahtanggafinal.sav' pada Download 3. 
Penyajian Indeks 


\section{Penyajian Indeks}

Penyajian indeks merupakan bagian penting dalam pemantauan. Bentuk penyajian yang tidak tepat akan menyulitkan pengguna dalam memanfaatkan data seperti untuk analisis dan pengambilan keputusan. Prinsip-prinsip dalam penyajian indeks kemiskinan adalah:

1. Mudah didapatkan dan dilihat serta membantu dalam analisis

2. Sesuai dengan dan mendukung tujuan pemantauan, bisa membantu dalam memberikan jawaban atas pertanyaan-pertanyaan dasar pemantauan

3. Dapat semudah mungkin diintegrasikan dengan data-data lain untuk mendapatkan analisis yang lebih lengkap.

\section{Grafik Keadaan Kemiskinan Desa}

Dalam panduan ini, Desa Durian digunakan sebagai contoh studi kasus.

\section{Langkah 1: Menemukan kode desa}

Dalam pelaksanaan yang sebenarnya, kode desa dapat dilihat pada daftar resmi yang dikeluarkan Pemda. Tetapi untuk latihan ini Anda dapat menggunakan Tabel 8.9.

Walaupun demikian, sumber yang paling "asli" (sesuai dengan data di SPSS) adalah dengan melihatnya pada "Value Label,". "Value label" dapat dilihat dengan beberapa cara, tergantung pada versi program SPSS yang digunakan. Jika Anda menggunakan versi 9.0, "Value Label" dapat dilihat dengan cara:
- Klik kanan pada variabel yang Anda maksud (misal, var00001 untuk kode desa),

- Pilih "Define Labels".

Jika Anda menggunakan SPSS versi yang lebih baru:

- Masuklah ke "Variable View" (di sudut kiri bawah; Gambar 9.1),

- Klik dua kali "Variable View",

- Pilih kolom nilai pada baris variabel yang Anda maksud (misal, var00001).

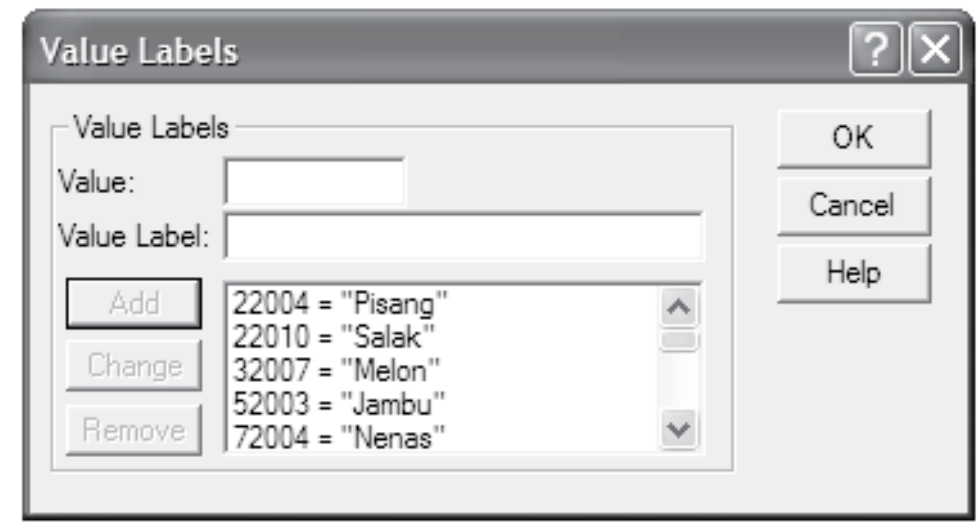

Gambar 9.1. Menu "Value Labels"

\section{Langkah 2: Menghitung Rata-rata Desa}

Karena penghitungan Anda sangat spesifik, Anda harus memilih "Select Cases", sehingga penghitungan Anda dibatasi pada responden dari Desa Durian saja.

Untuk itu, gunakan menu "Select Cases" (Gambar 9.2): "Data" >> "Select Cases"

Menu ini berfungsi untuk memilih kasus tertentu dalam analisis. Dalam menu "Select Cases" terdapat lima pilihan, juga ada satu pertanyaan tentang perlakuan pada kasus- 


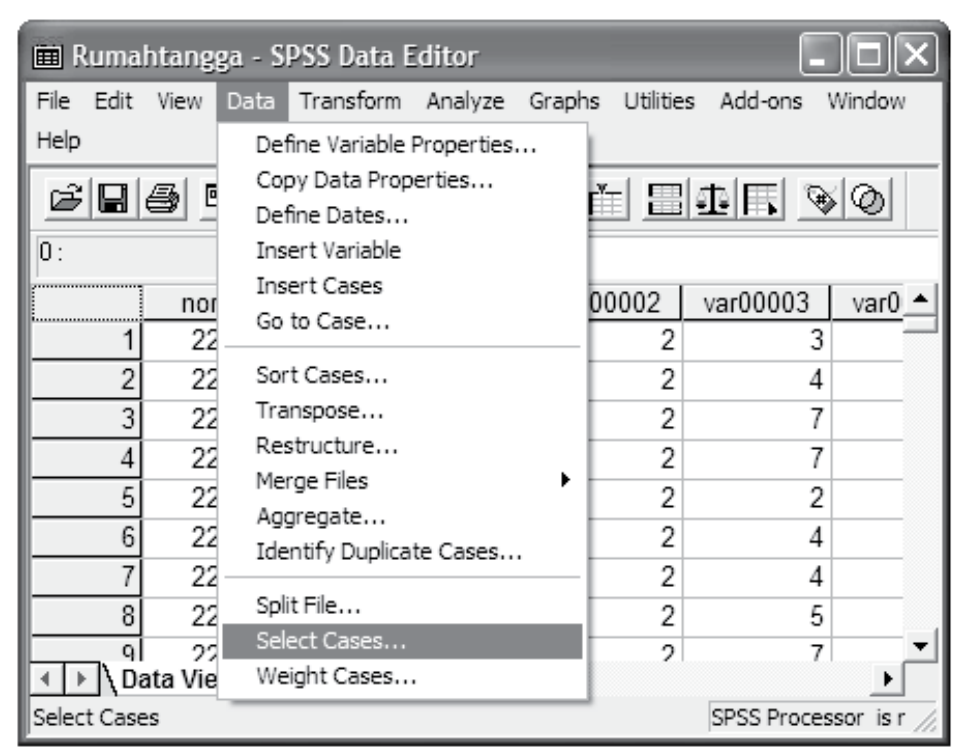

Gambar 9.2. Menu "Select Cases"

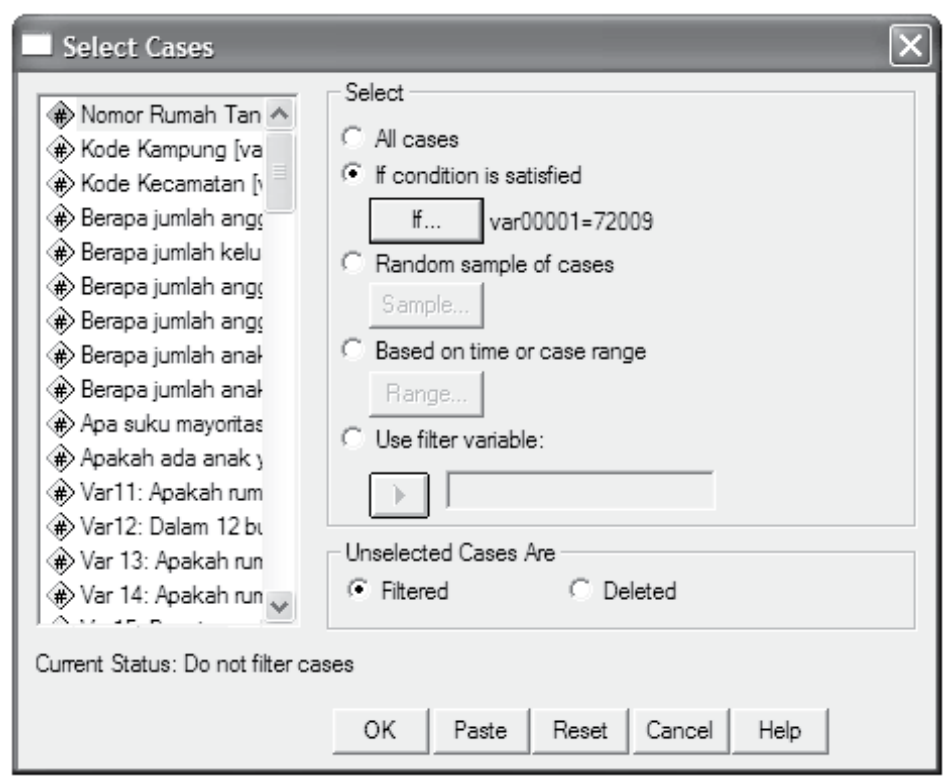

Gambar 9.3. Pilihan-pilihan pada menu "Select Cases" kasus yang tidak terpilih (lihat Gambar 9.3). Penjelasan tentang pilihan-pilihan tersebut termasuk isiannya dapat dilihat pada Tabel 9.4.

Setelah anda menentukan pilihan-pilihan tersebut berdasarkan Tabel 9.1, maka akan terlihat coretan pada nomor-nomor kasus yang tidak terpilih. Periksalah secara cepat apakah coretan-coretan tersebut memang terletak pada nomor kasus yang tidak terpilih (kasus selain Desa Durian) (lihat Gambar 9.4).

Tabel 9.1. Isi menu "Select Cases"

\begin{tabular}{|c|c|c|}
\hline $\begin{array}{l}\text { Pilihan \& } \\
\text { Kolom }\end{array}$ & Maksud & Yang harus dilakukan \\
\hline "All Cases" & $\begin{array}{l}\text { Seluruh kasus akan } \\
\text { dianalisis, artinya tidak } \\
\text { ada pemilihan }\end{array}$ & $\begin{array}{l}\text { Abaikan saja, Anda harus } \\
\text { melakukan pilihan }\end{array}$ \\
\hline $\begin{array}{l}\text { "IF } \\
\text { condition is } \\
\text { satisfied" }\end{array}$ & $\begin{array}{l}\text { Pemilihan berdasarkan } \\
\text { syarat-syarat pada } \\
\text { variabel tertentu }\end{array}$ & $\begin{array}{l}\text { Pilih ini. Klik "If", dan } \\
\text { Anda akan melihat } \\
\text { kotak dialog berikutnya. } \\
\text { Masukkan variabel kode } \\
\text { desa (var00001) ke dalam } \\
\text { kotak, ketik tanda 'sama } \\
\text { dengan' (=) dan masukkan } \\
\text { kode untuk Desa Durian, } \\
\text { yakni 72009, sehingga } \\
\text { tertulis (var00001 = 72009) }\end{array}$ \\
\hline $\begin{array}{l}\text { "Random } \\
\text { sample of } \\
\text { cases" }\end{array}$ & $\begin{array}{l}\text { Pemilihan berdasarkan } \\
\text { jumlah acak }\end{array}$ & Abaikan \\
\hline $\begin{array}{l}\text { "Based on } \\
\text { Time or Case } \\
\text { Range" }\end{array}$ & $\begin{array}{l}\text { Pemilihan berdasarkan } \\
\text { kisaran tertentu }\end{array}$ & Abaikan \\
\hline $\begin{array}{l}\text { "Use filter } \\
\text { variable" }\end{array}$ & $\begin{array}{l}\text { Pemilihan berdasarkan } \\
\text { variabel tertentu }\end{array}$ & Abaikan \\
\hline $\begin{array}{l}\text { "Unselected } \\
\text { Cases Are" }\end{array}$ & $\begin{array}{l}\text { Pilih apa yang ingin } \\
\text { Anda lakukan untuk } \\
\text { kasus yang tidak } \\
\text { dipilih, apakah disaring } \\
\text { (filtered) atau dihapus } \\
\text { (deleted). }\end{array}$ & Pilih "Filtered" \\
\hline
\end{tabular}




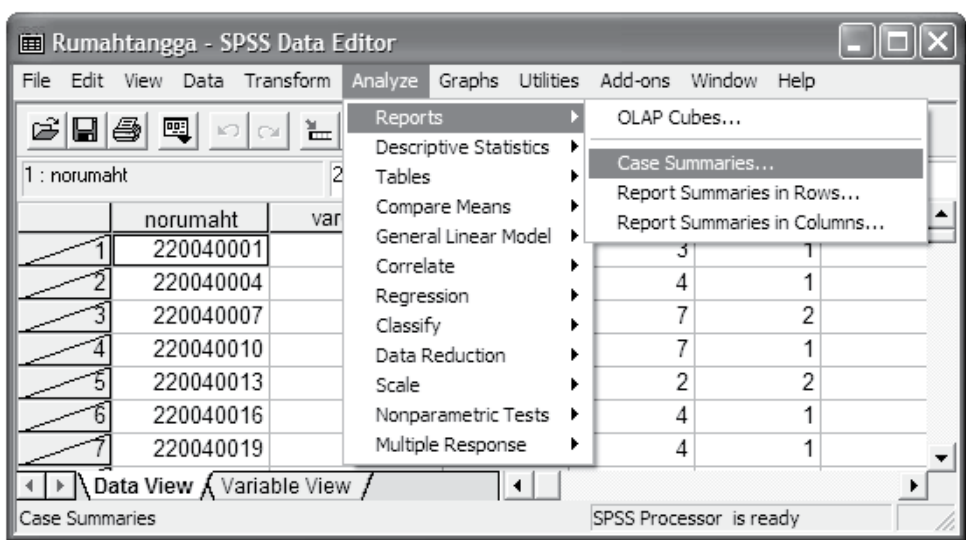

Gambar 9.4. Menu "Case Summaries"

Sebagai catatan penting, Anda harus harus selalu ingat ketika sudah selesai melakukan penghitungan atau analisis dengan "Select Cases," Anda harus mengembalikan posisinya pada posisi normal dengan cara memilih "All Cases."

Setelah pemilihan kasus selesai, selanjutnya adalah menghitung rata-rata nilai indeks untuk seluruh indeks (indeks dasar dan agregat), yaitu: kesehatan, kekayaan materi, pengetahuan, politik, ekonomi, sosial, alam, infrastruktur dan pelayanan, kesejahteraan subjektif, kesejahteraan inti, konteks, dan indeks agregat. Untuk menghitung rata-rata, gunakanlah menu "Case Summaries".

$$
\text { "Analysis" >> "Reports" >> "Case Summaries" }
$$

Penjelasan lebih lanjut tentang menu "Case

Summaries" dapat dilihat di Modul 8 (lihat Gambar 8.4).

Tabel 9.2 menjelaskan cara mengatur menu "Case Summaries".

Jika langkah Anda benar, Anda akan memperoleh file output
Tabel 9.2. Menu "Case Summaries"

\begin{tabular}{|l|l|l|}
\hline \multicolumn{1}{|c|}{ Kolom } & \multicolumn{1}{|c|}{ Maksud } & \multicolumn{1}{|c|}{$\begin{array}{c}\text { Yang harus } \\
\text { dilakukan }\end{array}$} \\
\hline "Variables" & $\begin{array}{l}\text { Variabel yang ingin Anda analisis } \\
\text { (misal, menghitung rata-rata) }\end{array}$ & Pilih 'Alam' \\
\hline $\begin{array}{l}\text { "Grouping" } \\
\text { (Variables) }\end{array}$ & $\begin{array}{l}\text { Variabel yang ingin Anda gunakan } \\
\text { untuk pengelompokan }\end{array}$ & $\begin{array}{l}\text { Pilih 'Var00001' } \\
\text { (kode desa) }\end{array}$ \\
\hline "Statistic" & $\begin{array}{l}\text { Jenis analisis statistik yang Anda } \\
\text { inginkan (misal, mean, sum, std- } \\
\text { dev) }\end{array}$ & $\begin{array}{l}\text { Pilih 'Mean' } \\
\text { (rata-rata) }\end{array}$ \\
\hline "Option" & $\begin{array}{l}\text { Tampilkan file output (misal, judul } \\
\text { yang Anda inginkan) }\end{array}$ & Abaikan \\
\hline $\begin{array}{l}\text { "Display } \\
\text { cases" }\end{array}$ & $\begin{array}{l}\text { Apakah Anda ingin menampilkan } \\
\text { seluruh kasus dengan lengkap }\end{array}$ & $\begin{array}{l}\text { Biarkan tidak } \\
\text { dicentang }\end{array}$ \\
\hline
\end{tabular}

seperti terlihat pada Gambar 9.5. Gunakan angka-angka pada kolom 'Durian' sebagai nilai indeks desa.

\section{Langkah 3: Membuat Grafik Batang}

Grafik batang harus dibuat dengan Microsoft Excel $®$ dengan cara:

Klik kanan tabel SPSS (Gambar 9.5) >> klik "Copy" >>. Buka lembar kerja Excel, tempatkan kursor pada sel kiri atas (sel A1) pada Lembar 1. Klik: "Edit" >> "Paste Special" >> "Unicode Text" >> "OK".

Isi tabel SPSS akan menempati lembar kerja Excel pada selnya masing-masing. Hapuslah kolom dan baris yang tidak perlu, sehingga hanya tersisa dua kolom, yaitu kolom nama-nama indeks dan kolom rata-rata (mean). Nama-nama indeks sebaiknya diperpendek agar tampilan dalam grafik dapat lebih menarik (lihat Gambar 9.6). 
Case Summaries

\begin{tabular}{|c|c|c|c|c|c|c|c|c|c|c|c|c|}
\hline Kode Kampung & $\begin{array}{l}\text { Perasaan } \\
\text { Subyektif }\end{array}$ & $\begin{array}{c}\text { Gizi dan } \\
\text { Kesehatan }\end{array}$ & $\begin{array}{c}\text { Kekayaan } \\
\text { Materi V15, } \\
\text { V16, V17 }\end{array}$ & $\begin{array}{l}\text { Pengetahuan } \\
\text { V18, V19, V20 }\end{array}$ & $\begin{array}{l}\text { Lingkungan } \\
\text { Alam V23a, } \\
\text { V24, V25, V26 }\end{array}$ & $\begin{array}{c}\text { Lingkungan } \\
\text { Ekonomi } \\
\text { V28a, V28b, } \\
\text { V29, V49 }\end{array}$ & $\begin{array}{c}\text { Lingkungan } \\
\text { Sisial V30 } \\
\text { V31 V32 }\end{array}$ & $\begin{array}{c}\text { Lingkungan } \\
\text { Politik V33 } \\
\text { V34 V35 }\end{array}$ & $\begin{array}{c}\text { Struktur\& } \\
\text { Pelayanan }\end{array}$ & $\begin{array}{c}\text { Inti: } \\
\text { kesehatan, } \\
\text { materi, } \\
\text { pengetahuan }\end{array}$ & $\begin{array}{c}\text { Konteks:Alam, } \\
\text { Ekonomi, } \\
\text { Sosial, Politik, } \\
\text { S\&P }\end{array}$ & $\begin{array}{l}\text { Agregat: Inti, } \\
\text { Lingkungan }\end{array}$ \\
\hline Durian & 46.6667 & 77.5000 & 60.8333 & 58.3333 & 72.3214 & 60.6250 & 67.5000 & 34.1667 & 59.6875 & 65.5556 & 58.8598 & 62.2077 \\
\hline Total & 46.6667 & 77.5000 & 60.8333 & 58.3333 & 72.3214 & 60.6250 & 67.5000 & 34.1667 & 59.6875 & 65.5556 & 58.8598 & 62.2077 \\
\hline
\end{tabular}

Gambar 9.5. Penghitungan Mean dengan "Case Summaries"

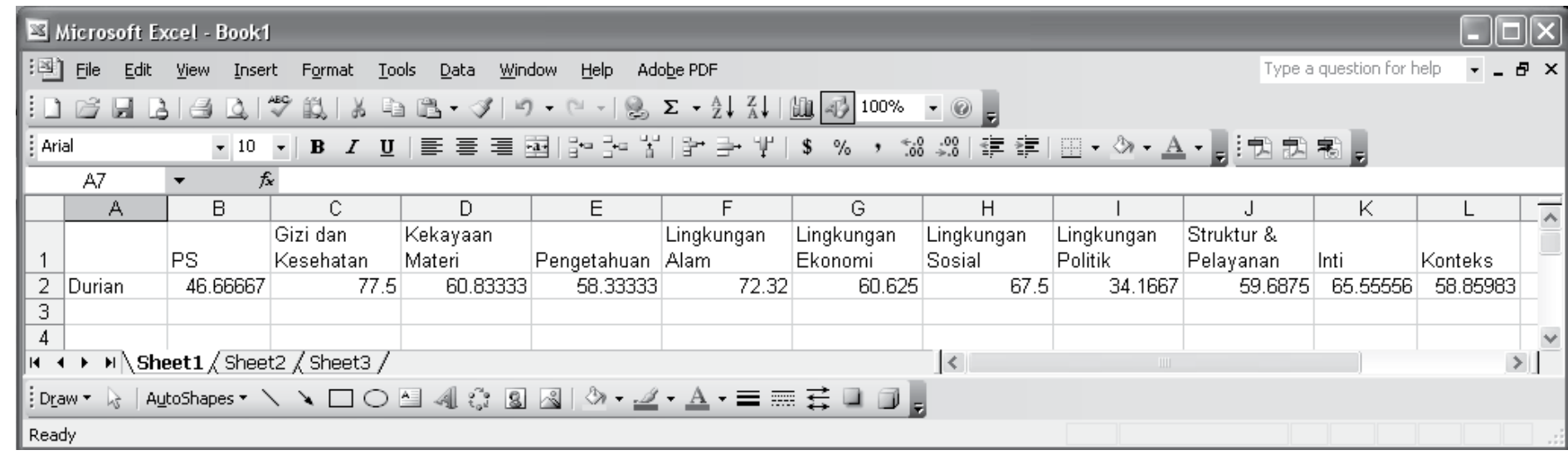

Gambar 9.6. Data yang dipindahkan ke Excel

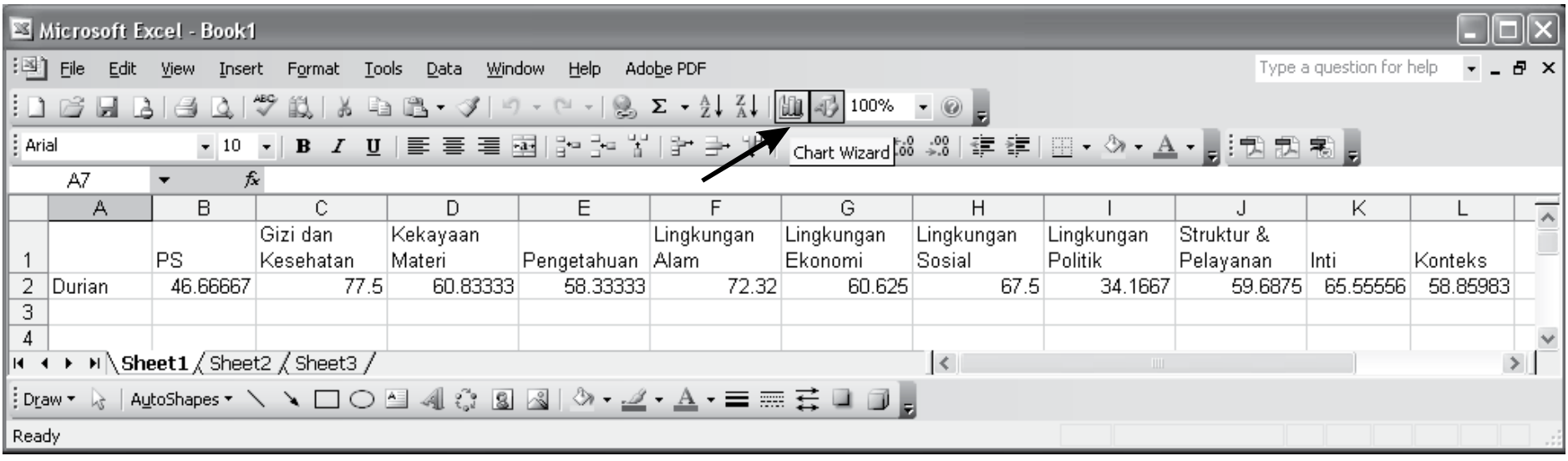

Gambar 9.7. Tombol menu "Chart Wizard" 
Untuk membuat grafik batang: Sorot seluruh sel yang berisi angka dan nama kolom; klik "tool," lalu "Chart Wizard" (lihat Gambar 9.7).

Anda akan mendapatkan menu "Chart Wizard" (Gambar 9.8). Pada langkah pertama (step 1 of 4), Anda diminta untuk memilih bentuk grafik yang diinginkan. Pilihlah grafik batang "Column" seperti yang nampak dalam Gambar 9.8. Lanjutkan proses berikutnya dengan mengklik tombol "Next".

Pada langkah kedua (step 2 of 4), Anda diminta memeriksa "Data Range" dan "Series in". "Data Range" adalah kisaran atau posisi data yang akan menjadi sumber grafik. Jika Anda

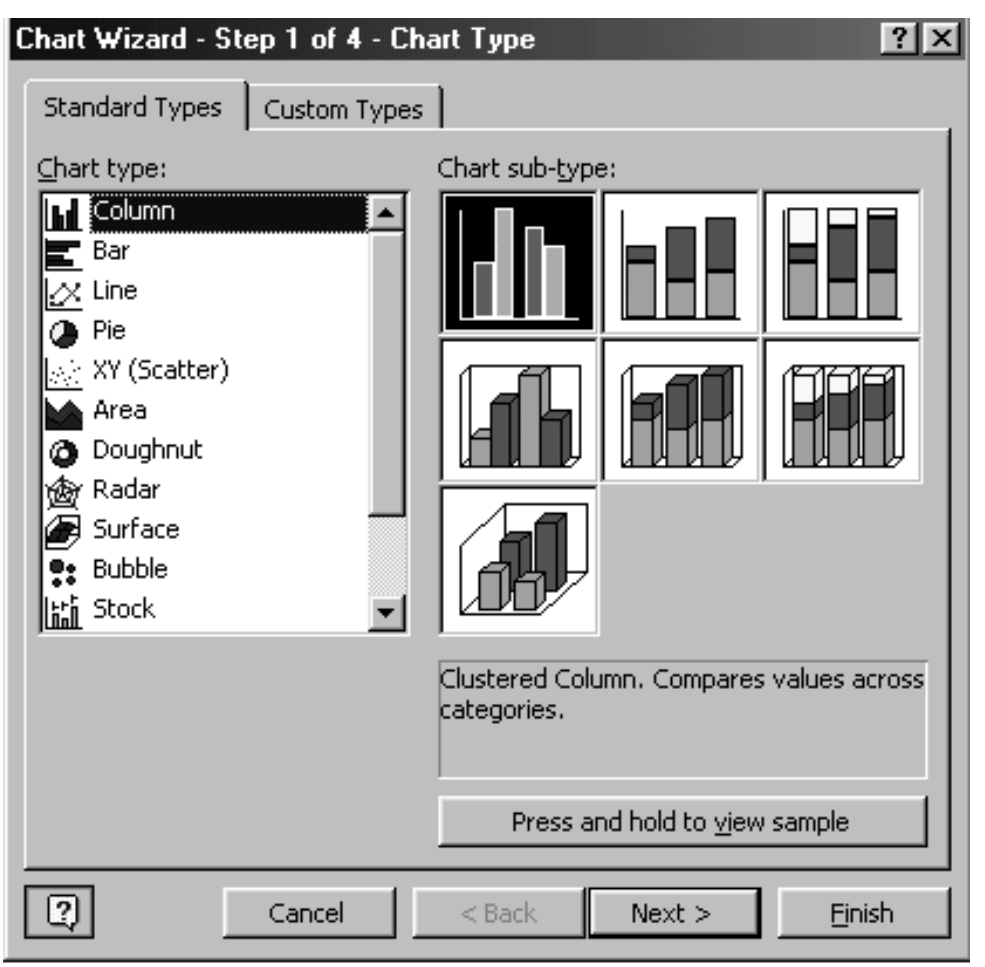

Gambar 9.8. Menu "Chart Wizard" sudah melakukan blok dengan benar, maka kolom "Data Range" akan terisi dengan benar pula, yaitu

$$
=\text { Sheet } 1 ! \$ A \$ 1: \$ L \$ 2
$$

Maksud dari kode di atas adalah bahwa sumber grafik berada pada "Sheet1" tepatnya antara sel A1 sampai L2. Anda dapat melihat (dari Gambar 9.6 dan 9.7) apakah kisaran datanya tepat.

"Series in" adalah menu untuk memilih seri data yang diinginkan. Pilih "Columns". Klik "Next" untuk proses selanjutnya.

Dalam proses selanjutnya (step 3 of 4), Anda berkesempatan untuk merancang grafik sesuai keinginan. Di sini Anda akan mendapatkan enam "tab" sub menu (Gambar 9.9). Setiap Anda melakukan sesuatu pada sub menu ini, tampilan grafik akan berubah. Anda dapat melihat secara "preview" pada kotak di sebelah kanannya. Penjelasan tentang sub menu

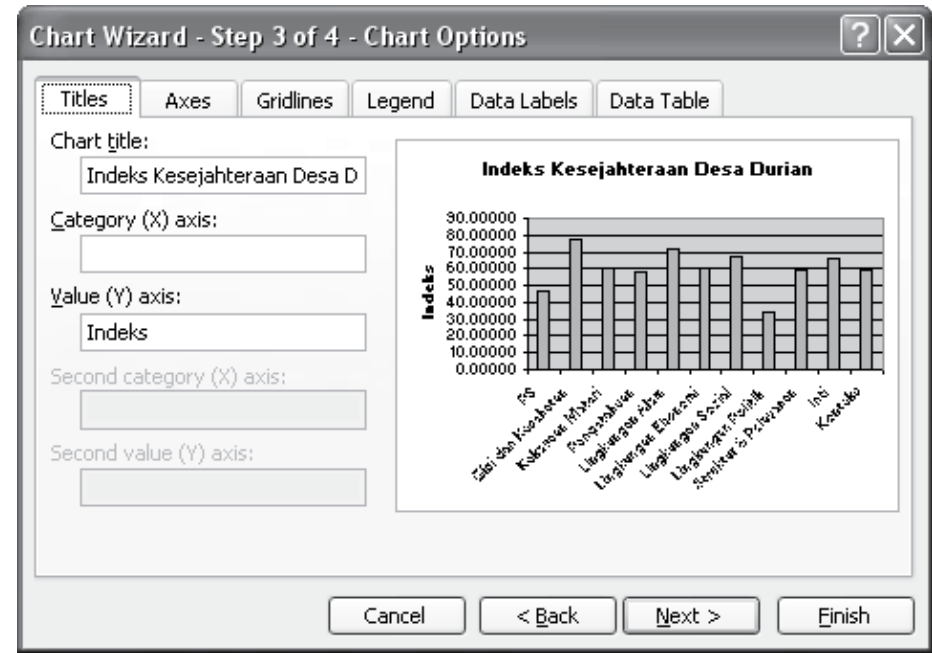

Gambar 9.9. Kotak dialog Langkah ke-3 "Chart Wizard": Menambahkan judul ke grafik 
dan isinya dapat dilihat pada Tabel 9.3. Jika Anda sudah merasa puas dengan rancangan ini, maka lanjutkan langkah berikutnya dengan mengklik "Next".

Langkah terakhir (step 4 of 4) memungkinkan Anda untuk memilih di mana grafik ditempatkan. Anda bisa menempatkannya pada lembar (I) tersendiri ("as new sheet") atau sebagai objek pada lembar tertentu ("as object in..."). Dalam latihan ini, pilihlah "as object in Sheet2". Jika langkah Anda benar, maka Anda akan mendapatkan grafik batang seperti tampak pada Gambar 9.10.

Sekarang Anda sudah memiliki grafik batang yang menunjukkan indeks kemiskinan Desa Durian.

Tabel 9.3. Maksud dan isi sub menu "Chart Wizard" langkah ke-3

\begin{tabular}{|c|c|c|}
\hline Submenu & Maksud & Yang harus dilakukan \\
\hline "Titles" & $\begin{array}{l}\text { Judul grafik. Anda } \\
\text { dapat membuat } \\
\text { judul grafik, kategori } \\
\text { sumbu X dan sumbu } \\
\text { nilai Y. } \\
\end{array}$ & $\begin{array}{l}\text { "Chart title": 'Grafik Indeks } \\
\text { Kemiskinan Desa Durian'. } \\
\text { "Category }(\mathrm{X}) \text { axis": biarkan } \\
\text { kosong. "Value }(\mathrm{Y}) \text { axis": } \\
\text { 'Indeks' }\end{array}$ \\
\hline "Axes" & $\begin{array}{l}\text { Anda dapat memilih } \\
\text { apakah Anda ingin } \\
\text { data ditampilkan } \\
\text { pada sumbu X atau Y }\end{array}$ & $\begin{array}{l}\text { Centang kedua sumbu. } \\
\text { Untuk sumbu X, pilih } \\
\text { "Automatic". }\end{array}$ \\
\hline "Gridlines" & $\begin{array}{l}\text { Anda dapat memilih } \\
\text { garis kisi-kisi }\end{array}$ & $\begin{array}{l}\text { Cukup pilih "Major gridline" } \\
\text { untuk sumbu Y }\end{array}$ \\
\hline "Legend" & $\begin{array}{l}\text { Anda dapat memilih } \\
\text { apakah keterangan } \\
\text { legenda) akan } \\
\text { ditampilkan }\end{array}$ & $\begin{array}{l}\text { Jangan dicentang, tidak } \\
\text { perlu ada legenda }\end{array}$ \\
\hline $\begin{array}{l}\text { "Data } \\
\text { Labels" }\end{array}$ & $\begin{array}{l}\text { Anda dapat memilih } \\
\text { apakah label atau } \\
\text { nilai ditampilkan }\end{array}$ & $\begin{array}{l}\text { Pilih "None", Anda tidak } \\
\text { perlu menampilkan label }\end{array}$ \\
\hline $\begin{array}{l}\text { "Data } \\
\text { Table" }\end{array}$ & $\begin{array}{l}\text { Anda dapat memilih } \\
\text { apakah tabel data } \\
\text { ditampilkan di } \\
\text { samping grafik }\end{array}$ & $\begin{array}{l}\text { Abaikan. Anda tidak perlu } \\
\text { menampilkan tabel data }\end{array}$ \\
\hline
\end{tabular}

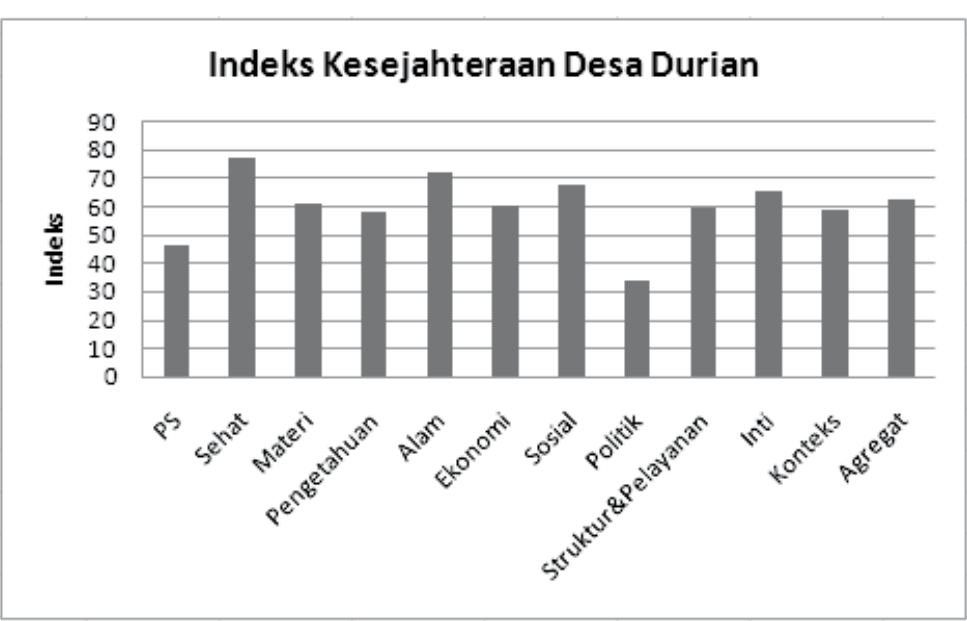

Gambar 9.10. Grafik batang indeks kemiskinan desa

Dari grafik batang ini, Anda dapat membuat corak pada setiap batangnya untuk mencerminkan klasifikasi indeks, yaitu: miskin dengan warna hitam penuh, sedang diwakili dengan abu-abu, dan sejahtera dengan putih. Untuk itu, Anda perlu melihat klasifikasi nilai indeks (lihat Lampiran 2). Berdasarkan klasifikasi ini, Anda dapat membuat indeks klasifikasi untuk Desa Durian (Tabel 9.4).

Pembuatan corak dapat dilakukan dengan mengklik batang. Pada klik pertama biasanya seluruh batang akan terpilih, jika Anda klik untuk kedua kalinya maka hanya batang yang Anda klik yang dipilih. Setelah Anda yakin bahwa hanya batang yang Anda maksud yang dipilih (dapat dilihat dengan adanya kotak-kotak di atasnya), klik kanan sehingga akan muncul beberapa menu. Pilihlah menu "Format Data Point" (lihat Gambar 9.11).

Jika Anda menghendaki batang warna putih, maka pilih "None" pada area itu, lalu klik "OK". Jika Anda ingin hitam, maka biarkan saja seperti apa adanya. Jika Anda ingin abuabu, klik warna abu-abu. Untuk garis batas, pilih "None" 
Tabel 9.4. Klasifikasi indeks untuk Desa Durian

\begin{tabular}{|l|l|l|}
\hline \multicolumn{1}{|c|}{ Indeks } & \multicolumn{1}{c|}{ Klasifikasi } & \multicolumn{1}{c|}{ Corak Batang } \\
\hline Kesehatan dan Gizi & Sejahtera & Putih \\
\hline Kekayaan Materi & Sejahtera & Putih \\
\hline Pengetahuan & Sedang & Abu-abu \\
\hline Alam & Sejahtera & Putih \\
\hline Ekonomi & Sejahtera & Putih \\
\hline Sosial & Sejahtera & Putih \\
\hline Politik & Sedang & Abu-abu \\
\hline Infrastruktur dan Pelayanan & Sedang & Abu-abu \\
\hline Kesejahteraan Inti & Sejahtera & Putih \\
\hline Konteks & Sedang & Abu-abu \\
\hline
\end{tabular}

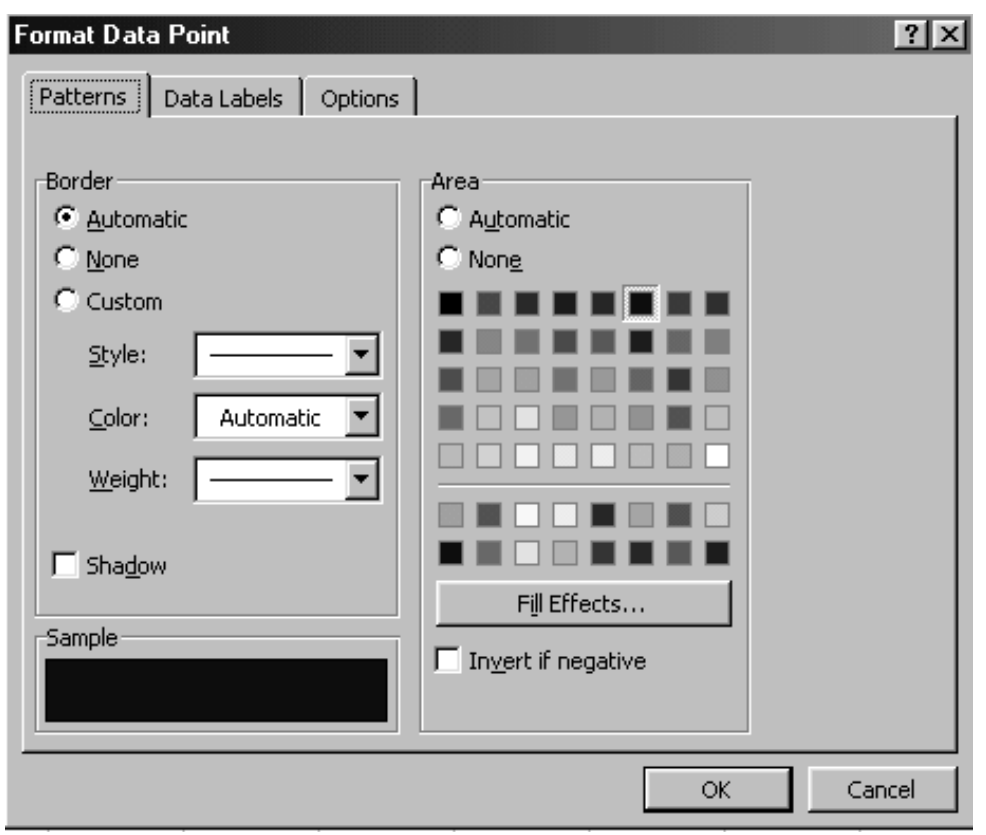

Gambar 9.11. Menu "Format Data Point"

(lihat Gambar 9.11), lalu klik "OK" dan"OK". Jika langkah Anda benar, maka Anda akan mendapatkan grafik seperti Gambar 9.12.
Indeks Kesejahteraan Desa Durian

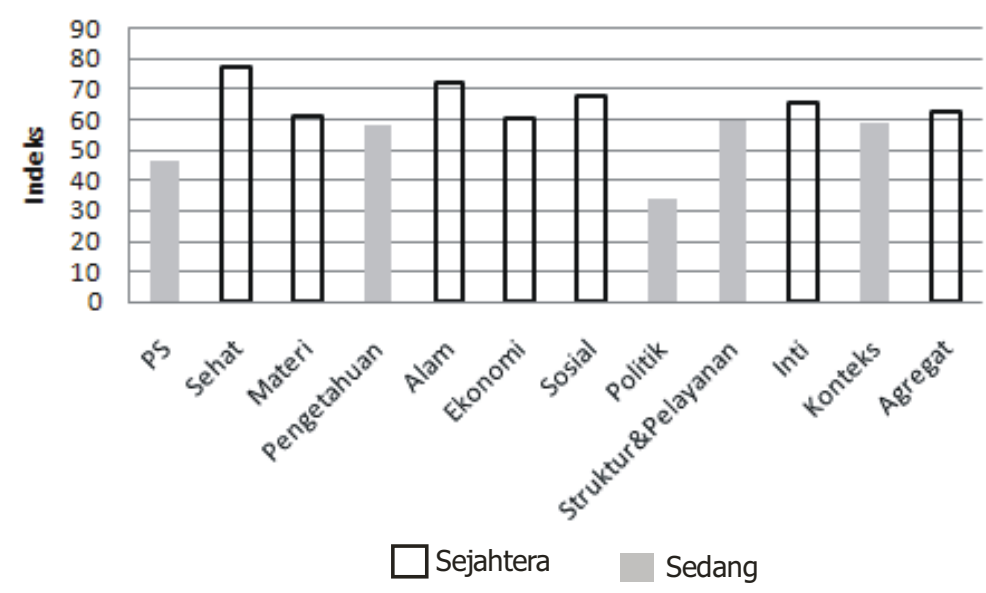

Gambar 9.12. Grafik batang kemiskinan desa dengan klasifikasi

\section{Grafik Kemiskinan Kecamatan}

Grafik kemiskinan tingkat kecamatan sangat penting untuk pemerintah kecamatan dalam mengelola pembangunan di kecamatannya. Karena skalanya lebih luas, tentunya grafik kecamatan tidak mungkin menampilkan kesebelas indeksnya. Tetapi kita dapat menampilkan indeks agregat desa - satu indeks per desa yang mewakili seluruh indeks lainnya. Kita dapat juga menampilkan indeks untuk lingkungan yang sama untuk seluruh desa pada kecamatan tersebut (grafik sektoral).

Sebagai contoh, Anda diminta untuk membuat grafik indeks pengetahuan di Kecamatan Jati. Karena lembar data SPSS mencakup seluruh data dari enam kecamatan, Anda harus memilih Jati saja. Anda dapat melakukannya dengan menggunakan menu "Select Cases" (lihat Gambar 9.2 dan 9.4), dengan isi seperti ditampilkan pada Tabel 9.5. 
Tabel 9.5. "Select Cases" untuk Kecamatan Jati

\begin{tabular}{|l|l|}
\hline Pilihan dan Kolom & \multicolumn{1}{|c|}{ Yang harus dilakukan } \\
\hline "All Cases" & Abaikan, Anda harus memilih satu kasus saja \\
\hline $\begin{array}{l}\text { "IF condition is } \\
\text { satisfied" }\end{array}$ & $\begin{array}{l}\text { Pilih ini. Pada kotak ini, masukkan variabel } \\
\text { kecamatan dan kode kecamatan untuk Jati } \\
\text { (varO0002 = 7). Nomor 7 adalah kode untuk } \\
\text { Kecamatan Jati. }\end{array}$ \\
\hline $\begin{array}{l}\text { "Random sample of } \\
\text { cases" }\end{array}$ & Abaikan \\
\hline $\begin{array}{l}\text { "Based on Time or } \\
\text { Case Range" }\end{array}$ & Abaikan \\
\hline $\begin{array}{l}\text { "Use filter variable" } \\
\text { Are" }\end{array}$ & Abaikan \\
\hline
\end{tabular}

Total rata-rata per desa dapat dihitung dengan menggunakan menu "Case Summaries" (Gambar 8.4). Isi menu "Case Summaries" ditampilkan pada Tabel 9.6.

Tabel 9.6. Menu "Case Summaries" untuk Kecamatan Jati

\begin{tabular}{|l|l|}
\hline \multicolumn{1}{|c|}{ Kolom } & \multicolumn{1}{c|}{ Yang harus dilakukan } \\
\hline "Variabel" & Pilih 'Pengetahuan' \\
\hline "Grouping (Variables)" & Pilih 'Var00001' (kode desa) \\
\hline "Statistic" & Pilih 'Mean' \\
\hline "Option" & Abaikan \\
\hline "Display Cases" & Biarkan tidak dicentang \\
\hline
\end{tabular}

Dari perhitungan di atas, akan didapatkan nilai rata-rata (mean) indeks pengetahuan untuk setiap desa di kecamatan Jati. Seperti saat membuat grafik desa, di sini Anda juga dapat menyalin file output ke lembar kerja Excel. Lihat Gambar 9.6 sampai dengan Gambar 9.11 dan Tabel 9.3 dan 9.4 untuk mendapatkan hasil seperti pada Gambar 9.13.
Indeks pengetahuan untuk desa-desa di Kecamatan Jatì

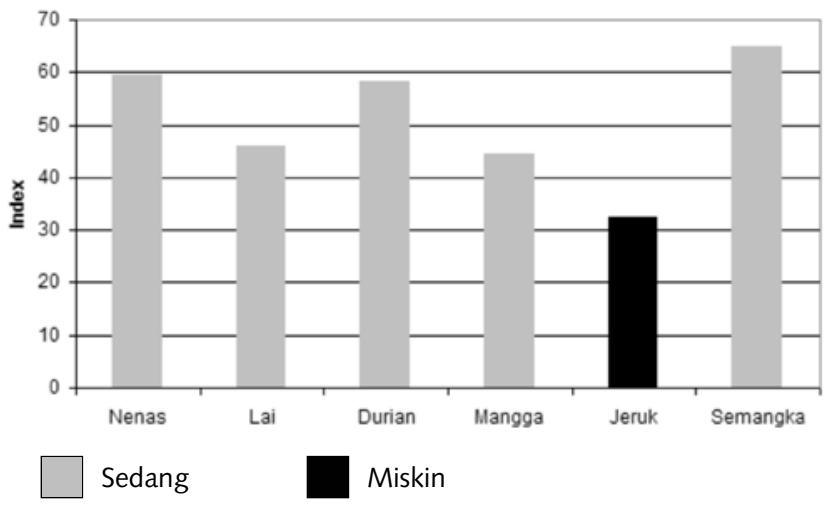

Gambar 9.13. Indeks pengetahuan untuk desa-desa di Kecamatan Jati

\section{Peta Kemiskinan Daerah}

Penyajian dengan menggunakan peta dapat membantu visualisasi penyebaran geografis. Penyajian semacam ini cocok untuk para pengambil kebijakan yang bersifat umum dan berskala luas seperti kepala daerah atau politisi di DPRD, atau kelompok-kelompok masyarakat sipil pemerhati pembangunan.

Dengan program ArcView $®$, peta dapat disajikan dengan berbagai macam atribut data, sehingga data tabular (seperti data kemiskinan) dan data spasial dapat dipadukan dengan baik. Dalam panduan ini diasumsikan bahwa program ArcView telah terpasang dalam komputer Anda, sehingga petunjuk instalasinya tidak dijelaskan di sini.

\section{Istilah-istilah pada ArcView}

"Theme":

Sebuah lapisan grafis yang memuat kumpulan fitur geografis 
dan informasi. Sebuah "theme" biasanya memuat informasi geografis dengan tema tertentu untuk sebuah tipe fitur tunggal, yang bisa berupa vektor atau pun citra (contoh: Desa.SPH, Tutupanhutan.GRD).

"Table":

Sebuah file data yang berbentuk tabel, biasanya berisi informasi atribut dari suatu fitur geografis. Kolom-kolomnya memuat atribut dan baris-barisnya memuat rekaman data (record). "Table" adalah file dalam format TXT atau DBF yang mempunyai kolom yang bisa digabungkan dengan "theme" (contoh: Koordinat.TXT, Indeks.DBF).

"View":

"View" digunakan untuk visualisasi data. Bila "view" memuat lebih dari satu "theme" maka "theme" tersebut akan ditampilkan secara berurutan dari bawah ke atas. Komposisi peta yang ditampilkan merupakan tumpang susun (overlay) dari beberapa "theme".

"Layout":

"Layout" digunakan untuk merancang peta. Anda dapat menyusun "view" dan mengatur letak objek (legend, scale bar, dll.) sebelum mencetaknya.

\section{"Project":}

Sebuah file ArcView yang menyimpan data (theme dan table) dan output (view dan layout) yang dibuat oleh pengguna untuk suatu aplikasi tertentu.

\section{Menyiapkan Data dari SPSS}

Contoh: Anda diminta untuk menyajikan indeks lingkungan ekonomi untuk seluruh desa.

Sambil berfokus pada seluruh desa, pastikan menu "Select Cases" tidak dalam keadaan aktif, atau pilih "All Cases".
Untuk menyajikan indeks ekonomi dari setiap desa, Anda dapat menggunakan menu "Case Summaries" seperti dijelaskan di atas (lihat Gambar 8.4 dan 9.4 dan Tabel 8.6 dan 9.2).

Jika seluruhnya Anda lakukan dengan benar, Anda akan mendapatkan output seperti Tabel 9.7 (nilai setelah dibulatkan):

Tabel 9.7. Indeks ekonomi

"Case Summaries"

"Mean"
\begin{tabular}{|l|c|}
\hline \multicolumn{1}{|c|}{ Kode Desa } & Indeks Lingkungan Ekonomi \\
\hline Pisang & 61,46 \\
\hline Salak & 75,50 \\
\hline Melon & 65,77 \\
\hline Jambu & 47,58 \\
\hline Nenas & 58,49 \\
\hline Lai & 55,00 \\
\hline Durian & 60,63 \\
\hline Mangga & 70,63 \\
\hline Jeruk & 54,37 \\
\hline Semangka & 79,75 \\
\hline Anggur & 59,05 \\
\hline Sirsak & 29,17 \\
\hline Apel & 67,23 \\
\hline Rata-rata & 62,30 \\
\hline
\end{tabular}

\section{Memasukkan Data ke dalam Tabel “.shp”}

Sebelum membuka ArcView, copy seluruh file data spasial dari Download 4 (Poverty maps.zip).

Untuk membuka program ArcView, Anda dapat masuk ke daftar program dan mencari jalan pintas (shortcut) "ESRI", 
atau mencari shortcut di layar desktop (Gambar 9.14). Klik dua kali pada shortcut tersebut untuk membuka program ArcView.

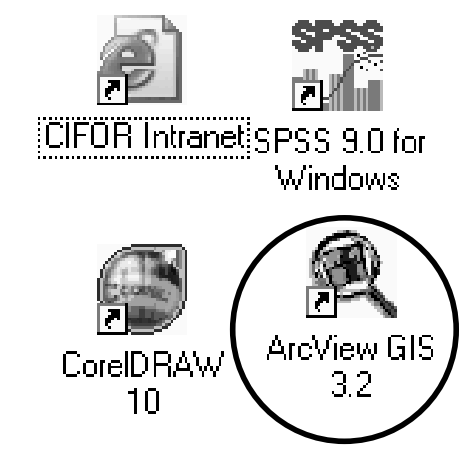

\section{Gambar 9.14. Shortcut ArcView}

Setelah program terbuka, Anda akan melihat kotak dialog "Welcome to ArcView GIS" (Gambar 9.15). Pilih "with a new view", lalu klik "OK".

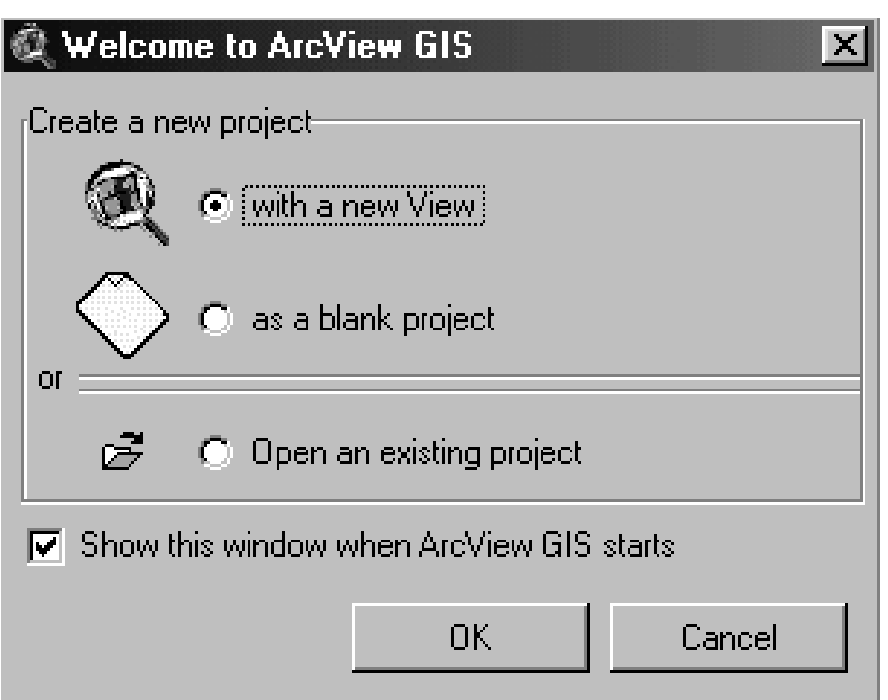

Gambar 9.15. Welcome to ArcView
Muncul kotak dialog yang menanyakan, "would you like to add data to View now?" Klik "Yes".

Kotak dialog "Add Theme" akan muncul, dan Anda dapat memasukkan data posisi desa (desa.shp) (lihat Gambar 9.16).

Pilih desa.shp dan klik "OK". Untuk mengaktifkan desa.shp, klik file "tab" desa.shp (centang) sehingga titik-titik lokasi desa ini tampak pada tampilan (Gambar 9.17).

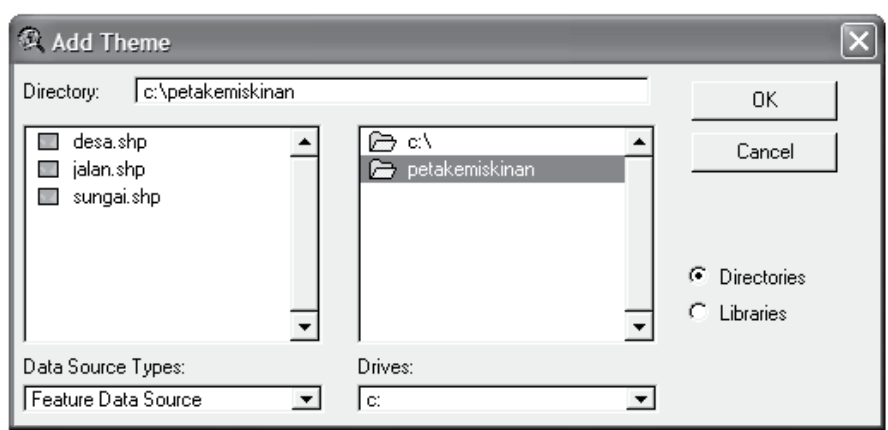

Gambar 9.16. Menu "Add Theme"

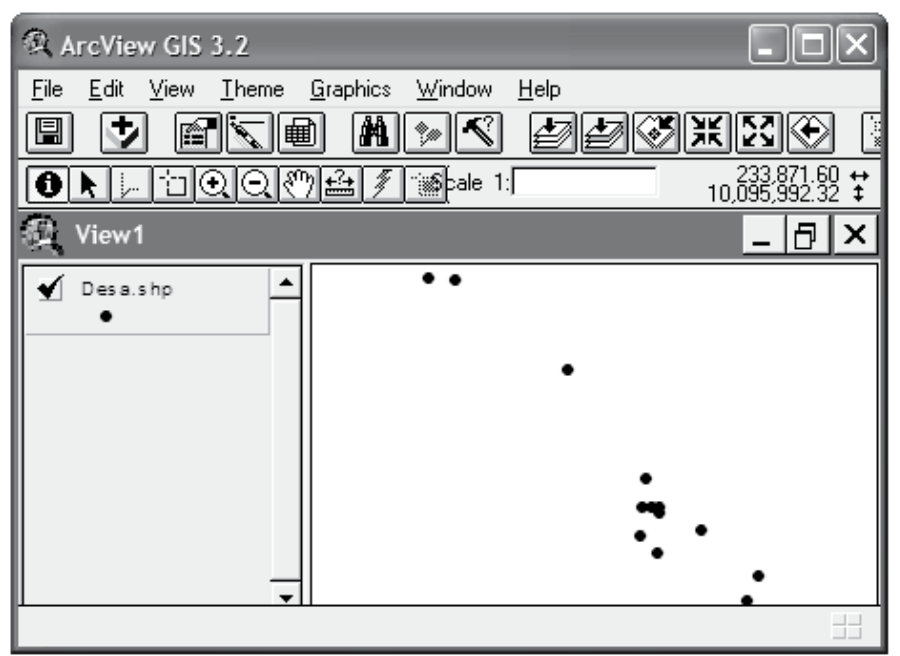

Gambar 9.17. Tampilan desa.shp 
Anda dapat menambahkan "theme" lainnya-jalan.shp, sungai.shp, dll. Anda dapat melakukannya menggunakan menu "Add Theme" seperti dijelaskan di atas (lihat Gambar 9.16).

Untuk menyimpan seluruh data dalam proyek ini, simpan proyek pada direkori peta kemiskinan:

$$
\text { "File" >> "Save Project As..." }
$$

Beri nama 'petakemiskinan.apr'.

Sekarang Anda sudah dapat memulai proses pemasukan data tabular indeks ekonomi ke dalam peta. Untuk itu, Anda harus mengklik "tab" file "theme" desa.shp karena data indeks ekonomi (yang diperoleh dari penghitungan SPSS) harus dimasukan ke dalam file ini. Setelah itu, klik menu "Open Theme Table" untuk membuka tabel data desa.shp (Gambar 9.18).

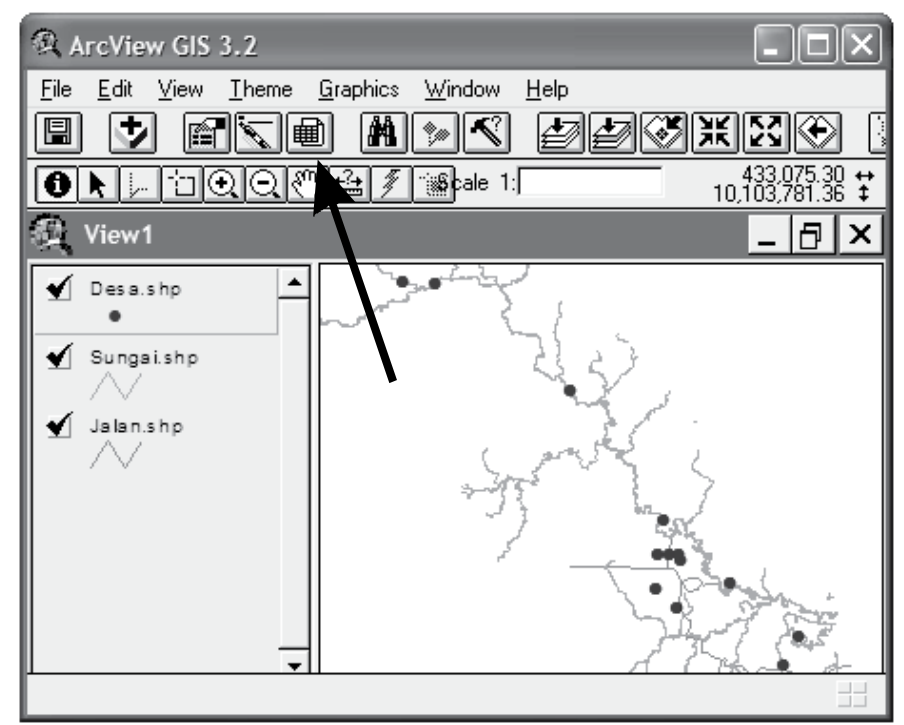

Gambar 9.18. Menu "Open Theme Table"
Setelah tabel terbuka, langkah selanjutnya adalah mengedit tabel tersebut dengan cara menambahkan field baru bernama Indeks-Kemiskinan. Untuk itu, Anda harus memulainya dengan menu "Start Editing" (Gambar 9.19):

"Table" >> "Start Editing"

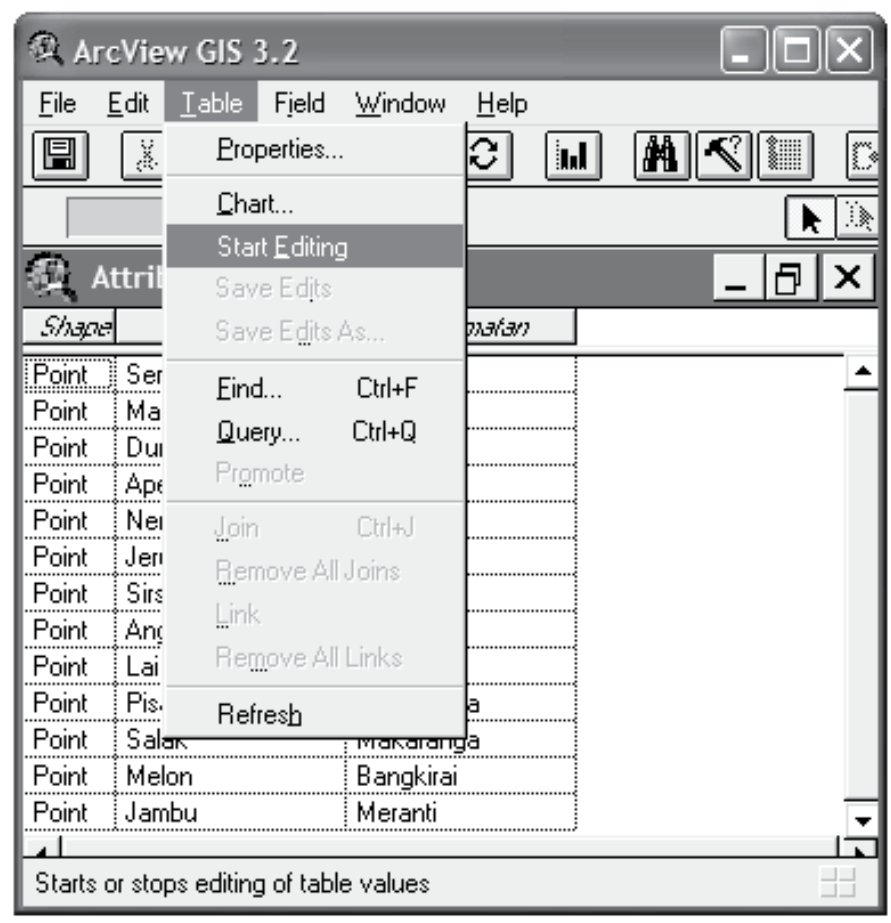

Gambar 9.19. Mengedit tabel

Proses pengeditan sekarang dimulai. Untuk menambah field (kolom), gunakan menu "Add Field"(Gambar 9.20):

$$
\text { "Edit" >> "Add Field" }
$$

Ketik nama 'Ekonomi'; untuk "Decimal Places," ketik '2'. Klik "OK". 


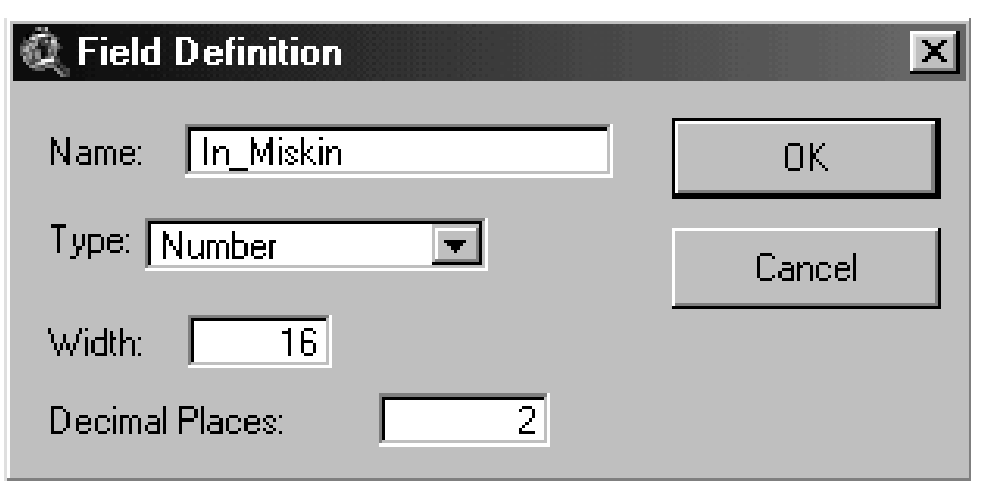

Gambar 9.20 Menu "Add Field"

Sekarang Anda memiliki kolom (field) tambahan bernama ‘Ekonomi' dengan format angka dua desimal.

Anda harus mengisikan data ke dalam tabel tersebut. Untuk memasukan data dari penghitungan SPSS di atas, gunakan menu "Edit" (Gambar 9.21).

Klik pada sel di mana Anda akan mengetik angka-angka. Masukkan data indeks Ekonomi tersebut untuk setiap desa berdasarkan penghitungan SPSS yang baru saja dilakukan (lihat Tabel 9.5).

Setelah selesai memasukkan seluruh data, simpan hasil edit Anda:

"Table" >> "Stop Editing" >> "Save Edit?" >> "Yes"

Anda sudah berhasil memasukkan data indeks kemiskinan pada peta lokasi desa (desa.shp). Gambar 9.22 menampilkan tabel setelah diedit.

Kembali ke "Views" dengan memilih:

“Window" >> klik 'Petakemiskinan.apr'

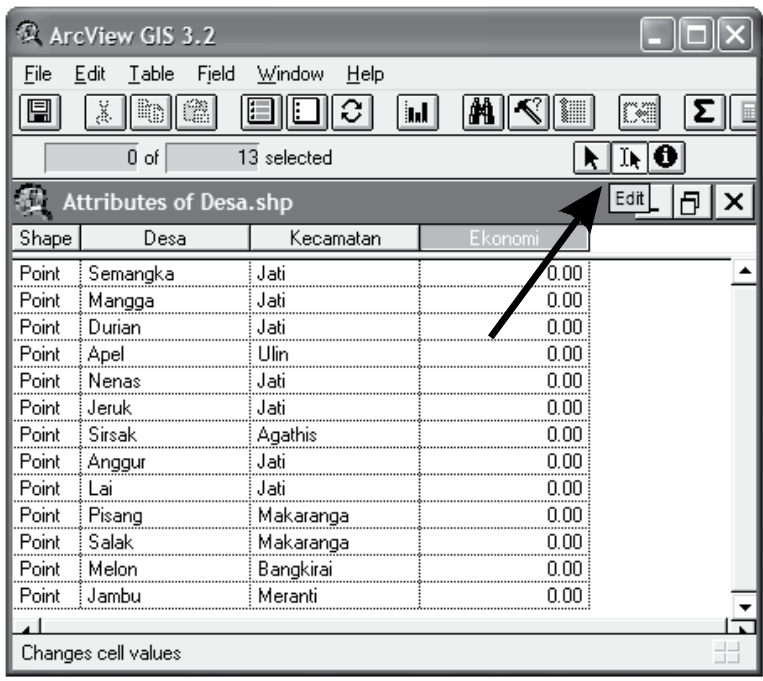

Gambar 9.21 Menu "Edit"

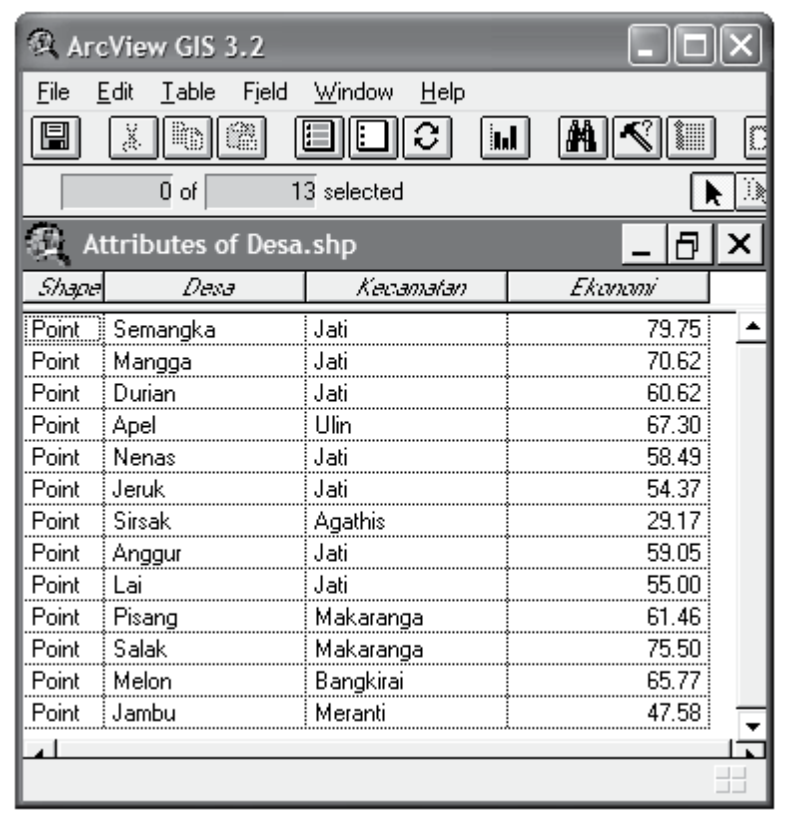

Gambar 9.22. Tabel Desa.shp setelah diedit 
Lalu buka "View1" dengan cara mengkliknya dua kali. Peta desa.shp yang berisi titik-titik posisi desa akan muncul. Untuk menambah analisis, tambahkan file "theme" lain seperti jalan.shp dan sungai.shp dengan menggunakan menu "Add Theme". Menu "Add Theme" dapat dimunculkan dengan menekan tombol "Add Theme" (Gambar 9.23).

Anda dapat mengatur simbol untuk sungai, jalan, titik desa, dll. dengan penebalan, pemilihan bentuk garis dan titik atau pewarnaan.

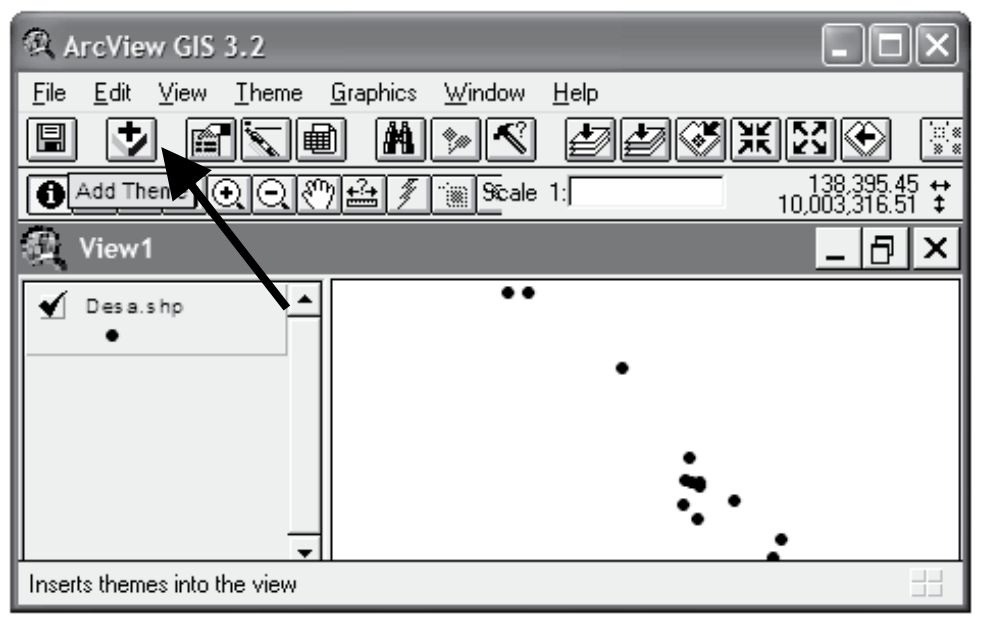

Gambar 9.23. Tombol menu "Add Theme"

\section{Pengaturan Titik Desa Berdasarkan Klasifikasi Indeks}

Langkah selanjutnya adalah menandai titik-titik desa pada tampilan yang berbeda-beda berdasarkan angka klasifikasi indeks (lihat Lampiran 2).

Pengaturan titik, garis, atau poligon di ArcView harus dilakukan dengan menu "Legend Editor" yang dapat ditemukan di:

\section{“Theme" >> "Edit Legend"}

Klik file "tab" yang ingin Anda atur (desa.shp), lalu buka menu "Legend Editor" (Gambar 9.24). Penjelasan serta isi menu 'Legend Editor' untuk keperluan klasifikasi titik desa berdasarkan nilai indeks dapat dilihat pada Tabel 9.6.

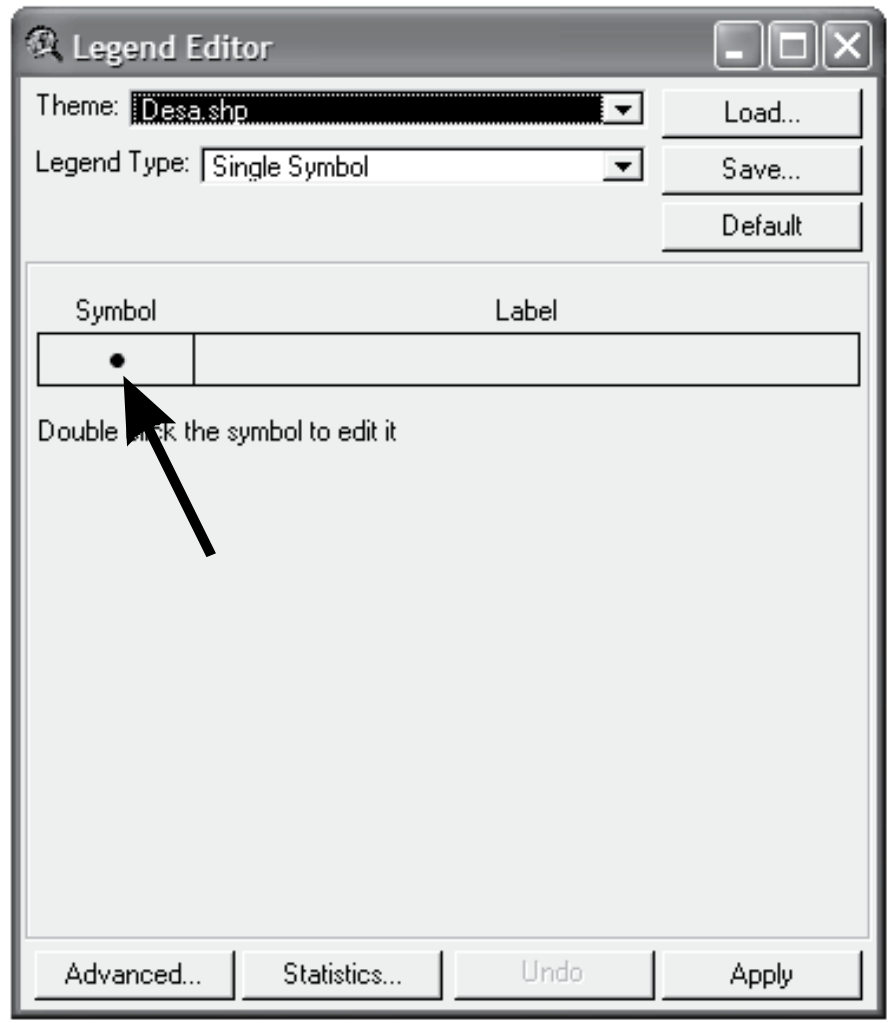

Gambar 9.24. Menu "Legend Editor"

Jika Anda melakukannya dengan benar, maka menu "Legend Editor" akan berubah dan Anda harus memilih "Classification Field". 
Tabel 9.6. Menu "Legend Editor"

\begin{tabular}{|l|l|l|}
\hline \multicolumn{1}{|c|}{ Kolom } & \multicolumn{1}{|c|}{ Maksud } & Isi / Yang harus dilakukan \\
\hline "Theme" & $\begin{array}{l}\text { Menampilkan file yang } \\
\text { sedang diubah }\end{array}$ & Harus terisi desa.shp \\
\hline $\begin{array}{l}\text { "Legend } \\
\text { Type" }\end{array}$ & $\begin{array}{l}\text { Memungkinkan Anda } \\
\text { memilih jenis legenda } \\
\text { yang diinginkan }\end{array}$ & $\begin{array}{l}\text { Pilih "Graduated } \\
\text { Symbol", karena Anda } \\
\text { ingin membuat simbol } \\
\text { berdasarkan klasifikasi }\end{array}$ \\
\hline "Symbol" & $\begin{array}{l}\text { Memungkinkan Anda } \\
\text { memilih jenis simbol } \\
\text { yang diinginkan (warna, } \\
\text { bentuk, corak). Hanya } \\
\text { digunakan jika Anda } \\
\text { memilih "Single Symbol" } \\
\text { sebagai jenis legenda. }\end{array}$ & Abaikan \\
\hline
\end{tabular}

"Classification Field" adalah data yang akan menjadi dasar bagi klasifikasi legenda. Pilih "Ekonomi". Sedangkan kolom "Normalized by" dibiarkan dengan pilihan "None".

Lalu gantilah "Symbol" dan "Value" sesuai dengan klasifikasi. Atur ukuran symbol size) menjadi 12. Hapus dua record terakhir dengan menyorotnya dan klik tanda silang yang berada di bawah (sebelah kanan tanda tambah), dan menu "Legend Editor" seperti pada Gambar 9.25 akan muncul.

Kolom "symbol" menunjukan lambang yang Anda inginkan berdasarkan kisaran nilai indeks yang ada pada kolom "value" dan " "Pada tahap terakhir, klik "Apply" (lihat Gambar 9.25).

Anda akan melihat sebaran desa dan klasifikasinya yang diwakili dengan lambang: kotak (miskin), lingkaran (sedang), dan segitiga (sejahtera).

Anda dapat mengetahui data setiap titik desa dengan cara:

- Mengaktifkan file "tab" desa.shp (theme) dengan mengkliknya sekali

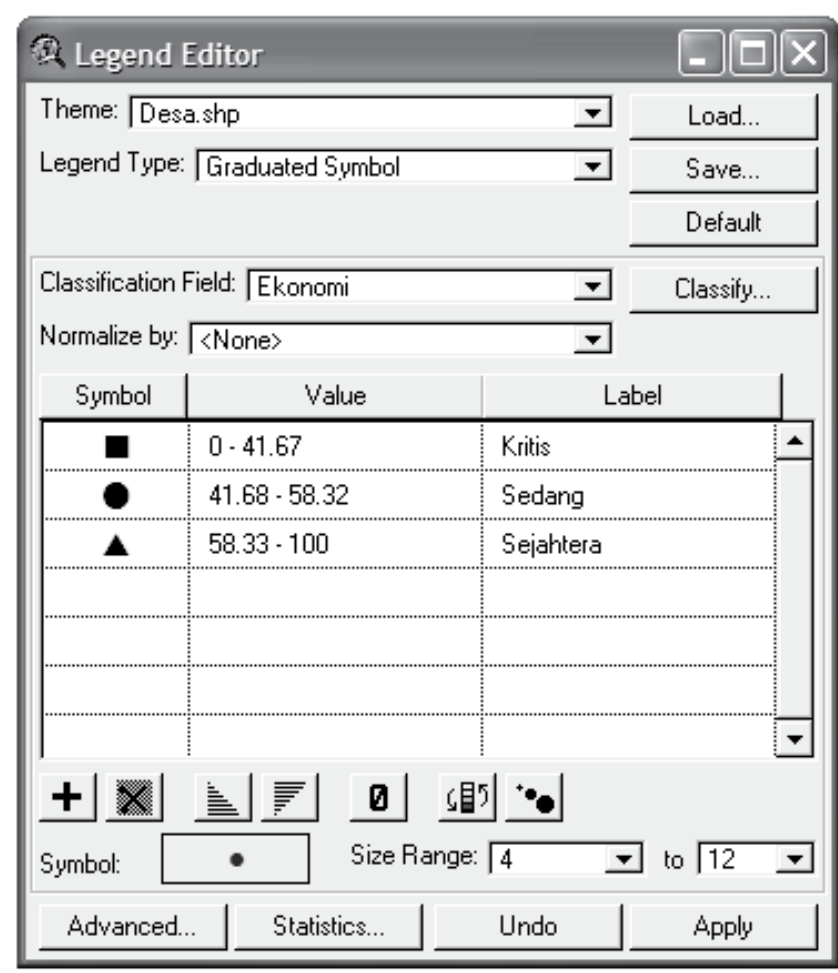

Gambar 9.25. Pengaturan "Graduated Symbol"

- Mengaktifkan menu "Identity" dengan mengklik "ikon" menu tersebut

- Mengklik titik yang ingin Anda lihat (lihat Gambar 9.26).

Pada gambar 9.26 terlihat bahwa menu "Identity" membantu menampilkan tabel yang khusus untuk titik yang ditunjuk, yaitu Desa Salak. Namun menu ini tidak dapat memberikan tulisan pada "view" (label), misalnya tulisan 'Salak' di samping titik desa tersebut.

Untuk dapat memberi label Desa Salak atau fitur geografis lainnya, gunakan menu "Label". Dalam kasus Desa Salak, langkah-langkahnya adalah sebagai berikut: 
- Aktifkan file "tab" 'desa.shp'

- Aktifkan menu "Label" dengan mengklik "ikon" label. Label tersedia tepat di kiri "ikon" text $(\mathrm{T})$,

- Klik Desa Salak.

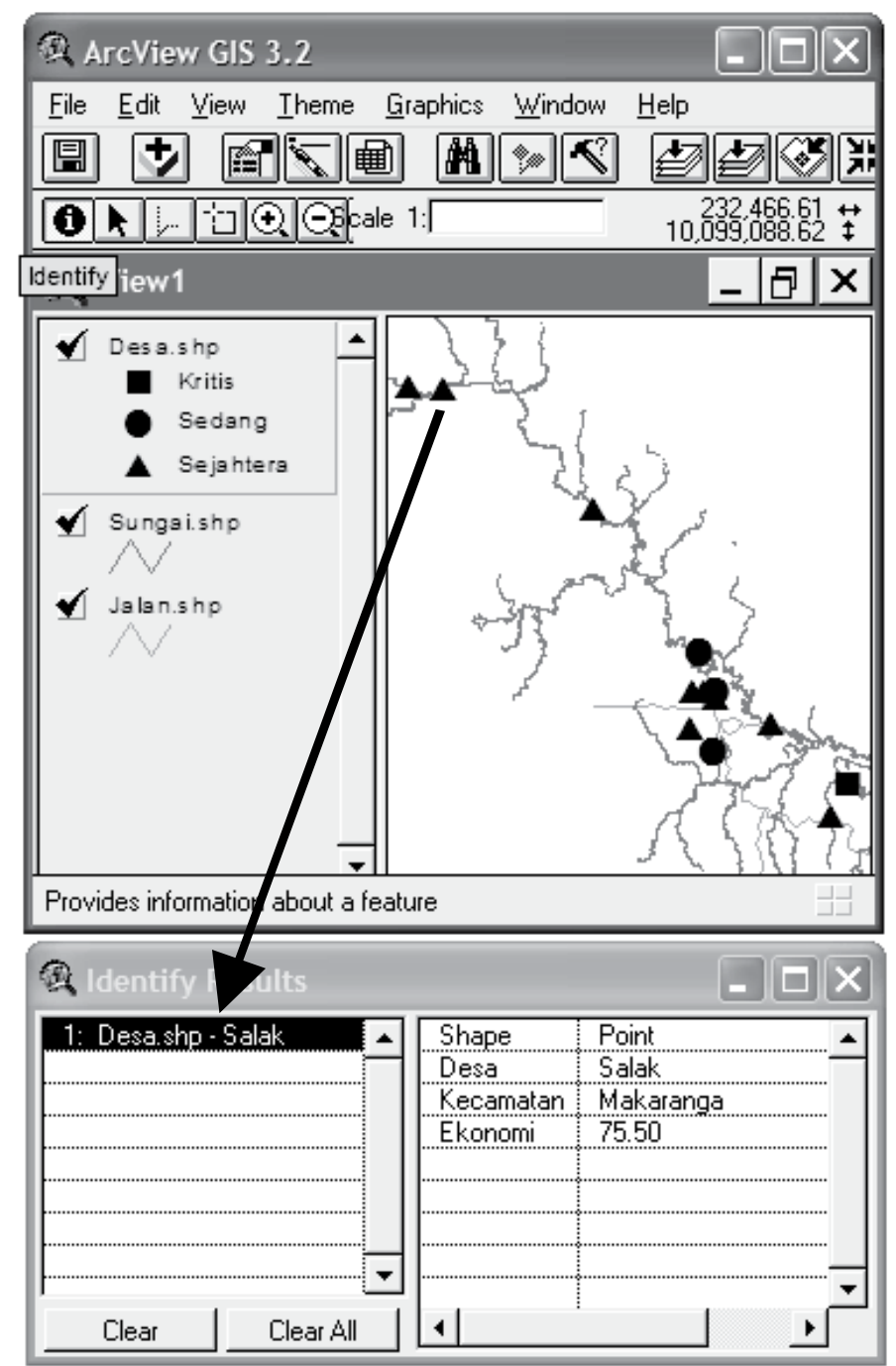

Gambar 9.26. Menggunakan menu "Identity"
Label akan muncul (lihat Gambar 9.26).

Penjelasan lebih rinci tentang pengaturan "palette" sekarang diperlukan. Pada dasarnya, Anda dapat mengatur penampakan huruf, garis, titik, ataupun poligon. Pengaturan tersebut dilakukan lewat "Palette Manager" yang dapat diakses lewat "Legend Editor" seperti dijelaskan sebelumnya atau lewat:

"Window" >> "Show Symbol Window..."

Pada menu "Palette Manager", terdapat enam pallete (lihat Gambar 9.27).

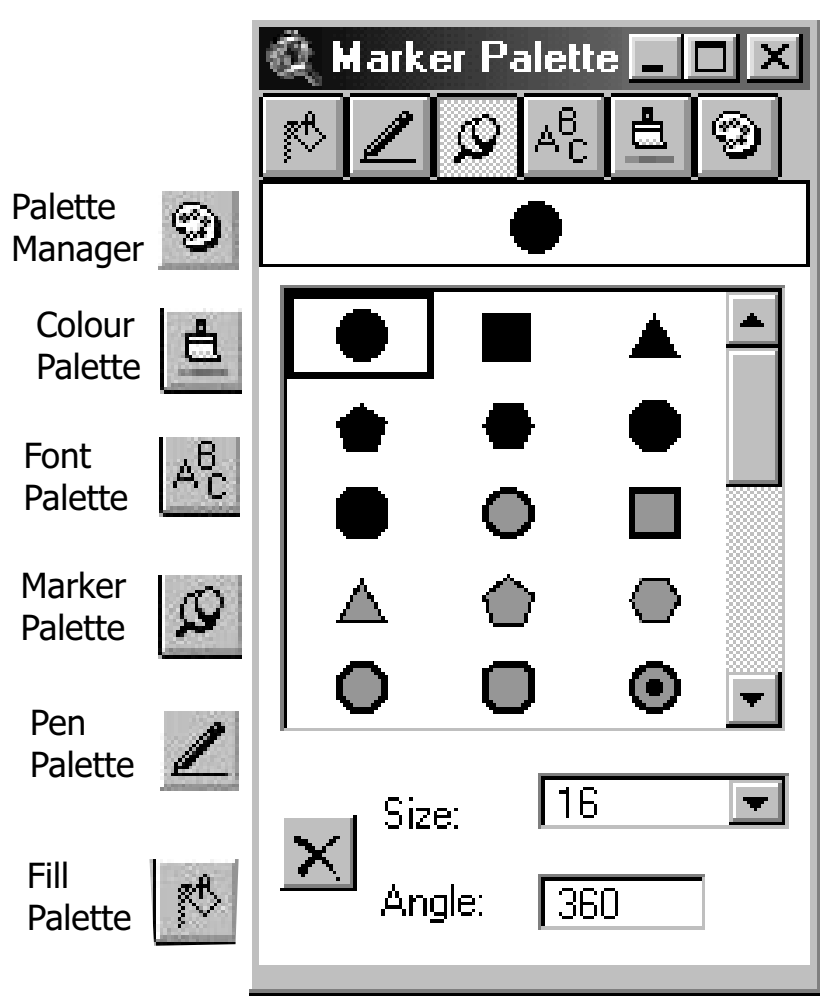

Gambar 9.27. "Palette Manager" 
Tiga dari enam palette tersebut berfungsi untuk mengatur bentuk titik, garis, dan huruf. Dua palette lainnya berfungsi untuk mengatur warna dan isi poligon. Sedangkan satu palette sisanya adalah pengatur palette secara umum. Penjelasan lebih rinci dapat dilihat pada Tabel 9.7.

Untuk menyimpan pekerjaan yang diselesaikan pada ArcView, gunakan "Save Project:"

$$
\text { "File" >> "Save Project" }
$$

Dengan demikian Anda sudah mampu menampilkan pola sebaran geografis pada peta dengan desa-desa yang dibedakan berdasarkan indeks kemiskinannya.

Gunakan cara yang sama untuk 10 indeks lainnya.
Tabel 9.7. Maksud menu "Palette Manager"

\begin{tabular}{|l|l|}
\hline \multicolumn{1}{|c|}{ "Ikon" } & \multicolumn{1}{c|}{ Maksud } \\
\hline "Palette Manager" & Pengaturan palette secara umum \\
\hline "Color Palette" & $\begin{array}{l}\text { Pengaturan warna. Foreground (latar depan) } \\
\text { digunakan untuk mengatur titik, garis, dan isi } \\
\text { poligon. Background (latar belakang) jarang } \\
\text { digunakan. Outline untuk mengatur garis tepi } \\
\text { pada poligon. Text untuk mengatur huruf. }\end{array}$ \\
\hline "Marker Palette" & Pengaturan bentuk titik \\
\hline "Pen Palette" & Pengaturan garis \\
\hline "Fill Palette" & Pengaturan corak di dalam poligon \\
\hline
\end{tabular}

Tentu saja Anda dapat lebih kreatif dengan ArcView. Untuk keterangan lebih lanjut, baca ArcView Users' Guide. 

Pemeriksaan Lapangan 


\section{Pemeriksaan Lapangan}

\section{Siapa yang Perlu Diperiksa}

Pemeriksaan cukup dilakukan pada desa-desa yang memiliki kejanggalan dalam datanya, misalnya:

- Mengganti lebih dari 20 persen responden, atau kesalahan dalam penomoran dan pemilihan responden

- Memiliki profil yang jauh berbeda dengan desa-desa yang sangat berdekatan

- Memiliki banyak jawaban yang seragam

- Lembar wawancara tampak bersih dan rapi

- Ada banyak jawaban kosong.

\section{Cara Pemeriksaan dan Pengambilan Tindakan}

Sebelum berangkat ke lapangan, siapkan seluruh data yang Anda rasa diperlukan untuk desa itu.

Buat kelompok diskusi dengan sedikitnya lima orang yang terdiri dari pengurus desa dan masyarakat biasa, termasuk pendatanya sendiri. Tanyakan pendapat mereka tentang:

1. Kesimpulan dari hasil survei. Kesimpulan dapat dibuat dengan menggunakan analisis frekuensi atas beberapa variabel.
2. Peringkat desa tersebut dibandingkan desa yang berdekatan.

3. Peringkat 10 rumah tangga.

Bila jawaban atas ketiga hal tersebut masuk akal atau dapat diterima, maka tidak perlu ada pemeriksaan lanjutan. Tetapi jika kesimpulannya tidak masuk akal, maka harus diambil langkah selanjutnya, yaitu:

- Periksa 15 persen rumah tangga yang ada dalam daftar lembar wawancara. Mintalah responden rumah tangga:

- untuk memberitahukan apakah pernah dikunjungi untuk diwawancarai. Pastikan Anda bertanya pada responden yang asli, karena anggota rumah tangga lain bisa jadi tidak tahu

- mengulang wawancara, kemudian bandingkan hasilnya.

- Jika seluruhnya mengaku pernah diwawancara dan jawabannya memang kurang lebih konsisten, maka kesalahan mungkin terjadi pada pemilihan responden sehingga pemilihan harus diulang. Rumah tangga yang terpilih kembali tidak perlu diwawancara ulang, sedangkan yang belum terpilih harus diwawancarai.

- Jika ada yang mengaku tidak pernah diwawancarai (walaupun cuma satu responden), maka wawancara harus diulang dengan terlebih dahulu memperbaiki pemilihan respondennya.

- Jika wawancara ulang tidak dapat dilakukan karena keterbatasan biaya, maka data desa tersebut harus dipertimbangkan untuk dihapus sama sekali. 
Catatan Akhir 


\section{Catatan Akhir}

Petunjuk rinci dalam panduan ini dikembangkan secara khusus untuk kebutuhan dan persyaratan di Kabupaten Kutai Barat, Indonesia. Namun kami berharap bahwa panduan ini juga dapat digunakan sebagai contoh praktis dalam mengembangkan sistem pemantauan kemiskinan dan kesejahteraan lokal di daerah lain. Pemerintah daerah yang ingin meningkatkan program pengurangan kemiskinannya juga bisa mempelajari publikasi CIFOR berikut ini:

Center for International Forestry Research (CIFOR) 2007 Towards wellbeing in forest communities: A source book for local government. Center for International Forestry Research, Bogor, Indonesia.
Publikasi ini, beserta berbagai laporan lain tentang kehutanan, kemiskinan, dan desentralisasi dapat diperoleh di:

http://www.cifor.cgiar.org/Research/Governance/ MainActivities/poverty_decentralisation.htm 
Lampiran 


\section{Lampiran 1. Kuisioner Pemantauan Resmi}

\section{Lembar Wawancara Rumahtangga}

Pemantauan Kemiskinan Kabupaten Kutai Barat tahun 2005
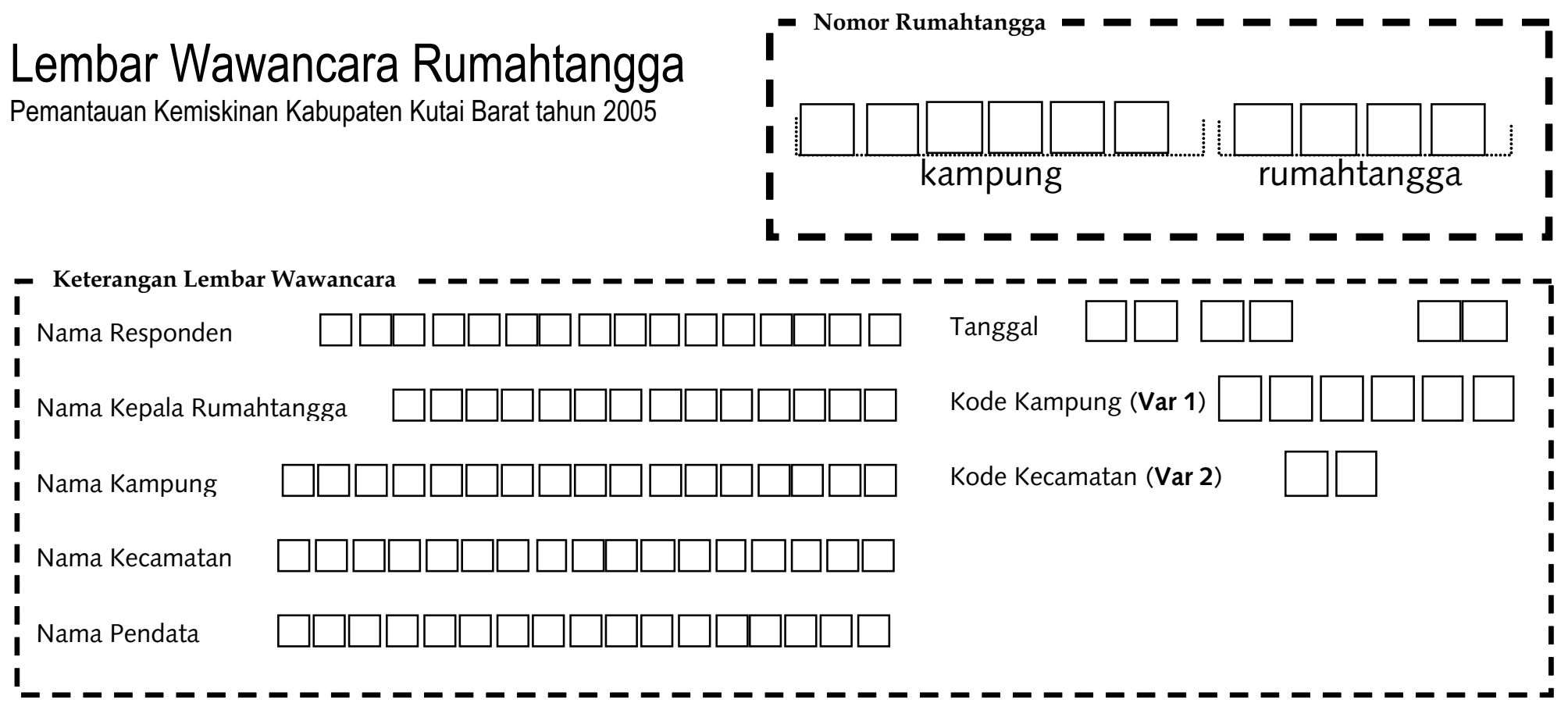

\begin{tabular}{|c|l|}
\hline$!$ & $\begin{array}{l}\text { Seluruh pertanyaan ini merupakan pertanyaan pada kondisi } 12 \text { bulan terakhir, dan hanya untuk keadaan di rumahtangga } \\
\text { atau kampung anda!. Isi hanya satu jawaban untuk setiap pertanyaan }\end{array}$ \\
\hline$!$ & Anggota rumahtangga adalah orang yang masih tinggal bersama di satu rumah atau masih dalam tanggungan \\
\hline
\end{tabular}




\begin{tabular}{|c|c|c|c|}
\hline \multicolumn{3}{|c|}{$\begin{array}{l}\text { Data Dasar Rumahtangga } \\
\text { Lingkari pilihan jawaban di bawah ini! }\end{array}$} & Isi kotak ini dengan angka \\
\hline Var 3 & \multicolumn{2}{|r|}{ Berapa jumlah anggota rumahtangga anda? } & \\
\hline Var 4 & \multicolumn{2}{|r|}{ Berapa jumlah keluarga yang ada di rumahtangga ini? } & \\
\hline Var 5 & \multicolumn{2}{|r|}{ Berapa jumlah anggota rumahtangga laki-laki dewasa yang masih hidup? } & \\
\hline Var 6 & \multicolumn{2}{|r|}{ Berapa jumlah anggota rumahtangga perempuan dewasa yang masih hidup? } & \\
\hline Var 7 & \multicolumn{2}{|r|}{ Berapa jumlah anak laki-laki yang masih hidup (usia di bawah 17 tahun)? } & \\
\hline Var 8 & \multicolumn{2}{|r|}{ Berapa jumlah anak perempuan yang masih hidup (usia di bawah 17 tahun)? } & \\
\hline \multirow[t]{2}{*}{ Var 9} & \multicolumn{2}{|r|}{ Apa suku mayoritas di rumahtangga anda? } & $\begin{array}{l}\text { Isi kotak ini dengan angka sesuai dengan } \\
\text { pilihan yang dilingkari }\end{array}$ \\
\hline & \multicolumn{2}{|r|}{$\begin{array}{l}1 \text { Benuaq, } 2 \text { Tunjung, } 3 \text { Bahau, } 4 \text { Kayan, } 5 \text { Kutai, } 6 \text { Bentian, } 7 \text { Kenyah, } 8 \text { Seputan, } \\
9 \text { Bukat, } 10 \text { Bakumpai, } 11 \text { Oheng, } 12 \text { Penihing, } 13 \text { Luangan, } 14 \text { Bugis, } 15 \text { Banjar, } \\
16 \text { Jawa, } 17 \text { Batak, } 18 \text { Suku lain }\end{array}$} & \\
\hline \multirow[t]{4}{*}{ Var 10} & \multicolumn{2}{|r|}{$\begin{array}{l}\text { Apakah ada anak yatim piatu, janda atau orang/anak cacat di rumahtangga } \\
\text { anda? }\end{array}$} & \\
\hline & 1 & Ya, ada lebih dari satu orang & \\
\hline & 2 & Ya, ada satu orang & \\
\hline & 3 & Tidak ada & \\
\hline \multirow[t]{4}{*}{ Var 11} & \multicolumn{2}{|r|}{ Apakah rumahtangga anda sejahtera? } & \\
\hline & 1 & Tidak, kami tidak sejahtera & \\
\hline & 2 & Lumayan & \\
\hline & 3 & Ya, kami sejahtera & \\
\hline
\end{tabular}




\begin{tabular}{|c|c|c|c|}
\hline & \multicolumn{2}{|r|}{ LINGKARI PILIHAN JAWABAN DI BAWAH INI! } & $\begin{array}{l}\text { ISI KOTAK INI DENGAN ANGKA SESUAI } \\
\text { DENGAN PILIHAN YANG DILINGKARI }\end{array}$ \\
\hline \multicolumn{4}{|c|}{ Gizi \& Kesehatan } \\
\hline \multirow[t]{3}{*}{ Var 12} & \multicolumn{2}{|r|}{$\begin{array}{l}\text { Dalam } 12 \text { bulan terakhir, apakah pernah terjadi kekurangan bahan makanan } \\
\text { selama lebih dari satu bulan? }\end{array}$} & \\
\hline & 1 & Ya, pernah & \\
\hline & 3 & Tidak pernah & \\
\hline \multirow[t]{4}{*}{ Var 13} & \multicolumn{2}{|r|}{$\begin{array}{l}\text { Apakah rumahtangga anda bisa mendapatkan air yang bersih untuk air } \\
\text { minum (tidak harus dari PDAM)? }\end{array}$} & \\
\hline & 1 & Tidak & \\
\hline & 2 & Ya, tapi tidak selalu (kadang-kadang) & \\
\hline & 3 & Ya, selalu bisa mendapatkan & \\
\hline \multirow[t]{5}{*}{ Var 14} & \multicolumn{2}{|r|}{$\begin{array}{l}\text { Apakah rumahtangga anda selalu mendapatkan pelayanan kesehatan baik } \\
\text { medis (dokter, mantri) maupun tradisional (dukun, belian) ketika ada anggota } \\
\text { rumahtangga yang sakit? }\end{array}$} & \\
\hline & 1 & Tidak pernah & \\
\hline & 2 & Kadang-kadang dapat & \\
\hline & 3 & Ya, selalu dapat & \\
\hline & 3 & Tidak pernah ada yang sakit dalam 12 bulan terakhir & \\
\hline \multicolumn{3}{|c|}{ Kekayaan Materi } & \\
\hline \multirow[t]{4}{*}{ Var 15} & \multicolumn{2}{|r|}{$\begin{array}{l}\text { (SILAKAN NILAI SENDIRI, JANGAN TANYAKAN) Bagaimana keadaan dan } \\
\text { kualitas rumah responden? }\end{array}$} & \\
\hline & 1 & Di bawah standar rata-rata & \\
\hline & 2 & Di standar rata-rata & \\
\hline & 3 & Di atas standar rata-rata & \\
\hline \multirow[t]{3}{*}{ Var 16} & \multicolumn{2}{|r|}{$\begin{array}{l}\text { (SILAKAN LIHAT SENDIRI, JANGAN TANYAKAN) Apakah rumahtangga anda } \\
\text { memiliki sepeda motor atau mesin ces/mesin spid/ketinting? }\end{array}$} & \\
\hline & 1 & Tidak & \\
\hline & 3 & Ya & \\
\hline \multirow[t]{3}{*}{ Var 17} & \multicolumn{2}{|r|}{$\begin{array}{l}\text { (SILAKAN LIHAT SENDIRI, JANGAN TANYAKAN) Apakah rumahtangga anda } \\
\text { memiliki parabola atau kulkas? }\end{array}$} & \\
\hline & 1 & Tidak & \\
\hline & 3 & $\mathrm{Ya}$ & \\
\hline
\end{tabular}




\begin{tabular}{|c|c|c|c|}
\hline & \multicolumn{2}{|r|}{ LINGKARI PILIHAN JAWABAN DI BAWAH INI! } & $\begin{array}{l}\text { ISI KOTAK INI DENGAN ANGKA SESUAI } \\
\text { DENGAN PILIHAN YANG DILINGKARI } \\
\end{array}$ \\
\hline \multicolumn{4}{|c|}{ Pengetahuan } \\
\hline \multirow[t]{4}{*}{ Var 18} & \multicolumn{2}{|r|}{$\begin{array}{l}\text { Apa tingkat pendidikan tertinggi dari anggota rumahtangga dewasa } \\
\text { (termasuk kepala rumahtangga)? }\end{array}$} & \\
\hline & 1 & Sekolah Rakyat (SR) atau SD atau Kejar Paket A atau kurang & \\
\hline & 2 & SMP atau lulus kejar paket B & \\
\hline & 3 & SLTA atau yang lebih tinggi atau kejar Paket $\mathrm{C}$ & \\
\hline \multirow[t]{5}{*}{ Var 19} & \multicolumn{2}{|r|}{$\begin{array}{l}\text { Apakah ada anak-anak usia } 7 \text { s/d } 16 \text { tahun di rumahtangga anda yang } \\
\text { bersekolah (anak-anak yang dibiayai oleh rumahtangga anda)? }\end{array}$} & \\
\hline & 1 & Semua tidak bersekolah & \\
\hline & 2 & Ada yang bersekolah, tapi tidak semua & \\
\hline & 3 & Semua anak-anak bersekolah & \\
\hline & 3 & Tidak ada anak-anak yang berusia $7 \mathrm{~s} / \mathrm{d} 17$ tahun & \\
\hline \multirow[t]{4}{*}{ Var 20} & \multicolumn{2}{|r|}{$\begin{array}{l}\text { Apakah ada anggota rumahtangga yang memiliki keterampilan atau } \\
\text { pengetahuan di luar bidang pertanian yang tidak didapatkan dari sekolah } \\
\text { (misalnya: keahlian pengobatan tradisional, tukang urut, pemeliatn, pengrajin, } \\
\text { sopir)? }\end{array}$} & \\
\hline & 1 & Tidak ada & \\
\hline & 2 & Ada satu orang & \\
\hline & 3 & Ada lebih dari satu orang & \\
\hline \multirow[t]{4}{*}{ Var 21} & \multicolumn{2}{|r|}{ Apakah anda merasa rumahtangga anda miskin? } & \\
\hline & 1 & Ya, kami miskin & \\
\hline & 2 & Lumayan & \\
\hline & 3 & Tidak & \\
\hline \multicolumn{4}{|c|}{ Lingkungan Alam } \\
\hline \multirow[t]{3}{*}{ Var 22} & \multicolumn{2}{|r|}{$\begin{array}{l}\text { Apakah anda sering masuk hutan (rimba, alas, bengkar, bukan belukar muda) } \\
\text { atau danau di wilayah kampung anda sendiri? }\end{array}$} & \\
\hline & 1 & Tidak & \\
\hline & 3 & $\mathrm{Ya}$ & \\
\hline
\end{tabular}




\begin{tabular}{|c|c|c|c|}
\hline & \multicolumn{2}{|r|}{ LINGKARI PILIHAN JAWABAN DI BAWAH INI! } & \begin{tabular}{|l} 
ISI KOTAK INI DENGAN ANGKA SESUAI \\
DENGAN PILIHAN YANG DILINGKARI
\end{tabular} \\
\hline \multirow[t]{6}{*}{ Var 23a } & \multicolumn{2}{|r|}{$\begin{array}{l}\text { Seberapa banyak lingkungan alam (mis: hutan, rapak, danau) di wilayah } \\
\text { kampung yang sudah rusak? }\end{array}$} & \\
\hline & 1 & Lebih dari setengah & \\
\hline & 2 & Setengah & \\
\hline & 3 & Kurang dari setengah & \\
\hline & 4 & Tidak ada yang rusak & \\
\hline & 99 & Saya tidak tahu & \\
\hline \multirow[t]{4}{*}{ Var 23b } & \multicolumn{2}{|r|}{$\begin{array}{l}\text { Dalam } 12 \text { bulan terakhir, apakah di wilayah kampung ini pernah terjadi } \\
\text { kebakaran hutan dan lahan? [TIDAK TERMASUK PEMBAKARAN UNTUK } \\
\text { PERSIAPAN LADANG YG DILAKUKAN DENGAN BAIK] }\end{array}$} & \\
\hline & \begin{tabular}{|l|l}
1 \\
\end{tabular} & Ya & \\
\hline & 3 & Tidak & \\
\hline & 99 & Saya tidak tahu & \\
\hline \multirow[t]{4}{*}{ Var 24} & \multicolumn{2}{|r|}{$\begin{array}{l}\text { Apakah masih ada burung enggang atau bangau tontong di sekitar hutan, } \\
\text { rawa atau danau di kampung ini? }\end{array}$} & \\
\hline & 1 & Tidak & \\
\hline & 3 & Ya & \\
\hline & 99 & Saya tidak tahu & \\
\hline \multirow[t]{4}{*}{ Var 25} & \multicolumn{2}{|r|}{$\begin{array}{l}\text { Apakah pernah terjadi dalam } 12 \text { bulan terakhir ini bahwa salah satu } \\
\text { sumberdaya alam (mis: ikan, burung, hewan liar, sarang burung, rotan, gaharu, } \\
\text { dII) pernah diambil sampai hampir habis? }\end{array}$} & \\
\hline & 1 & $\mathrm{Ya}$ & \\
\hline & 3 & Tidak & \\
\hline & \begin{tabular}{|l|l|}
99 \\
\end{tabular} & Saya tidak tahu & \\
\hline \multirow[t]{4}{*}{ Var 26} & \multicolumn{2}{|r|}{ Bagaimana kualitas air di sungai atau danau terdekat? } & \\
\hline & 1 & Buruk & \\
\hline & 2 & Sedang & \\
\hline & 3 & Baik & \\
\hline
\end{tabular}




\begin{tabular}{|c|c|c|c|c|c|}
\hline & \multicolumn{4}{|c|}{ LINGKARI PILIHAN JAWABAN DI BAWAH INI! } & $\begin{array}{l}\text { ISI KOTAK INI DENGAN ANGKA SESUAI } \\
\text { DENGAN PILIHAN YANG DILINGKARI }\end{array}$ \\
\hline \multicolumn{5}{|c|}{ Lingkungan Ekonomi } & \\
\hline \multirow[t]{11}{*}{$\begin{array}{l}\text { Var } 27 a, \\
27 b \& \\
27 c\end{array}$} & \multicolumn{4}{|c|}{$\begin{array}{l}\text { (PILIH PALING BANYAK } 3 \text { SUMBER PENDAPATAN PALING PENTING) Dalam } 12 \\
\text { bulan terakhir, apa sumber-sumber pendapatan uang paling diandalkan bagi } \\
\text { rumahtangga anda? }\end{array}$} & \\
\hline & 1 & Dagang & 11 & Fee lain/ganti rugi & \\
\hline & 2 & Fee kayu & 12 & Honor pengurus kampung & \\
\hline & 3 & Gaji PNS atau swasta & \multirow[t]{2}{*}{13} & \multirow{2}{*}{$\begin{array}{l}\text { Pertanian (sayur, kopi, ternak, } \\
\text { tambak) }\end{array}$} & \\
\hline & 4 & Dukungan keluarga & & & \\
\hline & 5 & Karet & 14 & Ikan (dari sungai atau danau) & \\
\hline & 6 & Rotan & 15 & Gaharu & \\
\hline & 7 & Sarang burung & 16 & Berburu & \\
\hline & 8 & Kayu & 17 & Hasil hutan lainnya & \\
\hline & 9 & Kerajinan tangan & 18 & Pelayanan (tukang, bengkel,dll) & \\
\hline & 10 & Kios/Warung/Toko & 19 & Lainnya (sebutkan) & \\
\hline \multirow[t]{3}{*}{ Var 28a } & \multicolumn{4}{|c|}{ Ada berapa jenis pendapatan responden? } & \\
\hline & 1 & Satu & & & \\
\hline & 3 & Lebih dari satu & & & \\
\hline \multirow[t]{3}{*}{ Var 28b } & & \multicolumn{3}{|c|}{ Apakah pendapatan tersebut merupakan pendapatan tetap? } & \\
\hline & 1 & \multicolumn{3}{|l|}{ Tidak ada yang tetap } & \\
\hline & 3 & \multicolumn{3}{|l|}{ Ya, ada yang tetap } & \\
\hline \multirow[t]{4}{*}{ Var 29a } & \multicolumn{4}{|c|}{$\begin{array}{l}\text { Berapa lama persediaan beras atau padi anda akan dapat bertahan untuk } \\
\text { bulan-bulan ke depan? }\end{array}$} & \\
\hline & 1 & \multicolumn{3}{|c|}{ Tidak ada persediaan (tidak berladang, atau gagal panen) } & \\
\hline & 2 & \multicolumn{3}{|c|}{ Sempat ada persediaan, tapi tidak cukup sampai panen saat ini } & \\
\hline & 3 & \multicolumn{3}{|c|}{ Cukup sampai panen saat ini } & \\
\hline
\end{tabular}




\begin{tabular}{|c|c|c|c|}
\hline & \multicolumn{2}{|r|}{ LINGKARI PILIHAN JAWABAN DI BAWAH INI! } & $\begin{array}{l}\text { ISI KOTAK INI DENGAN ANGKA SESUAI } \\
\text { DENGAN PILIHAN YANG DILINGKARI }\end{array}$ \\
\hline \multirow[t]{5}{*}{ Var 29b } & \multicolumn{2}{|r|}{$\begin{array}{l}\text { Jika tidak sempat memiliki persediaan beras atau persediaan tidak cukup } \\
\text { sampai panen saat ini, apakah rumahtangga anda selalu bisa membeli beras } \\
\text { tanpa kesulitan? }\end{array}$} & \\
\hline & 1 & Kadang-kadang kami tidak bisa beli beras & \\
\hline & 2 & Kami selalu bisa beli beras walaupun sulit & \\
\hline & 3 & Kami selalu bisa beli beras tanpa kesulitan & \\
\hline & 3 & Kami memiliki persediaan cukup sampai panen berikutnya & \\
\hline \multicolumn{3}{|c|}{ Lingkungan Sosial } & \\
\hline \multirow[t]{4}{*}{ Var 30} & \multicolumn{2}{|r|}{$\begin{array}{l}\text { Bagaimana tingkat tolong menolong (baik sumbangan tenaga maupun uang) } \\
\text { antar masyarakat di kampung ini? }\end{array}$} & \\
\hline & 1 & Rendah & \\
\hline & 2 & Sedang & \\
\hline & 3 & Tinggi & \\
\hline \multirow[t]{4}{*}{ Var 31} & \multicolumn{2}{|r|}{$\begin{array}{l}\text { Bagaimana rasa saling percaya antara orang dalam masyarakat di kampung } \\
\text { ini? }\end{array}$} & \\
\hline & 1 & Rendah & \\
\hline & 2 & Sedang & \\
\hline & 3 & Tinggi (kebanyakan orang dapat dipercaya) & \\
\hline \multirow[t]{3}{*}{ Var 32} & \multicolumn{2}{|r|}{$\begin{array}{l}\text { Apakah sering terjadi permasalahan antar orang atau keluarga di kampung } \\
\text { ini? }\end{array}$} & \\
\hline & 1 & Ya, sering & \\
\hline & 3 & Jarang terjadi & \\
\hline \multicolumn{3}{|c|}{ Lingkungan Politik } & \\
\hline \multirow[t]{4}{*}{ Var 33} & \multicolumn{2}{|r|}{$\begin{array}{l}\text { Apakah anda boleh mengambil hasil alam di wilayah kampung ini (mis: kayu, } \\
\text { ikan, sarang burung, emas, batu sungai, pasir dll) untuk dijual? }\end{array}$} & \\
\hline & 1 & Tidak boleh & \\
\hline & 2 & Boleh tapi ada kesulitan & \\
\hline & 3 & Boleh tanpa kesulitan & \\
\hline
\end{tabular}




\begin{tabular}{|c|c|c|c|}
\hline & \multicolumn{2}{|r|}{ LINGKARI PILIHAN JAWABAN DI BAWAH INI! } & $\begin{array}{l}\text { ISI KOTAK INI DENGAN ANGKA SESUAI } \\
\text { DENGAN PILIHAN YANG DILINGKARI }\end{array}$ \\
\hline \multirow[t]{4}{*}{ Var 34} & \multicolumn{2}{|r|}{$\begin{array}{l}\text { Apakah rumahtangga anda bisa mendapatkan berita atau informasi sehari- } \\
\text { hari (misalnya dari tv, koran, radio)? }\end{array}$} & \\
\hline & 1 & Tidak bisa & \\
\hline & 2 & Ya, bisa & \\
\hline & 3 & Ya, bahkan lebih dari satu sumber berita/informasi & \\
\hline \multirow[t]{4}{*}{ Var 35} & \multicolumn{2}{|r|}{$\begin{array}{l}\text { Apakah anda atau anggota rumahtangga yang lain ikut serta dalam } \\
\text { pengambilan keputusan (musyawarah) di kampung (tidak termasuk } \\
\text { keputusan lembaga adat dalam penyelesaian perselisihan)? }\end{array}$} & \\
\hline & 1 & Tidak pernah & \\
\hline & 2 & Kadang-kadang ikut serta & \\
\hline & 3 & Selalu ikut serta & \\
\hline \multirow[t]{4}{*}{ Var 36} & \multicolumn{2}{|r|}{ Apakah anda merasa rumahtangga anda bahagia? } & \\
\hline & 1 & Tidak, kami tidak bahagia & \\
\hline & 2 & Lumayan & \\
\hline & 3 & Ya, kami bahagia & \\
\hline \multicolumn{3}{|c|}{ Modul Ketergantungan Hutan } & \\
\hline \multirow[t]{4}{*}{ Var 37} & \multicolumn{2}{|r|}{$\begin{array}{l}\text { Apakah ada hasil panen ladang pada musim panen tahun lalu (Februari atau } \\
\text { Maret 2005)? }\end{array}$} & \\
\hline & 1 & Tidak karena tidak berladang ( LANGSUNG PILIH [1] PADA VAR 38 ) & \\
\hline & 3 & Tidak karena gagal panen & \\
\hline & 3 & Ya, kami panen tahun ini & \\
\hline \multirow[t]{7}{*}{ Var 38} & \multicolumn{2}{|r|}{$\begin{array}{l}\text { Berapa umur lahan (setelah terakhir diladangi) yang digunakan untuk ladang } \\
\text { tersebut? }\end{array}$} & \\
\hline & 1 & Tidak berladang & \\
\hline & 2 & Kurang dari 5 tahun & \\
\hline & 3 & Antara $5 \mathrm{~s} / \mathrm{d} 10$ tahun & \\
\hline & 4 & Antara $10 \mathrm{~s} / \mathrm{d} 20$ tahun & \\
\hline & 5 & Lebih dari 20 tahun & \\
\hline & 6 & Rimba yang belum pernah dibuka & \\
\hline
\end{tabular}




\begin{tabular}{|c|c|c|c|}
\hline & \multicolumn{2}{|r|}{ LINGKARI PILIHAN JAWABAN DI BAWAH INI! } & $\begin{array}{l}\text { ISI KOTAK INI DENGAN ANGKA SESUAI } \\
\text { DENGAN PILIHAN YANG DILINGKARI }\end{array}$ \\
\hline \multirow[t]{4}{*}{ Var 39} & \multicolumn{2}{|r|}{$\begin{array}{l}\text { Dalam } 12 \text { bulan terakhir, apakah hasil hutan bukan kayu (mis: gaharu, rotan, } \\
\text { damar, madu, sarang burung dll) penting bagi rumahtangga anda baik untuk } \\
\text { pendapatan uang maupun untuk pakai sendiri? }\end{array}$} & \\
\hline & 1 & Tidak penting & \\
\hline & 2 & Penting & \\
\hline & 3 & Sangat penting & \\
\hline \multirow[t]{4}{*}{ Var 40} & \multicolumn{2}{|r|}{$\begin{array}{l}\text { Dalam } 12 \text { bulan terakhir, apakah hewan buruan (mis: rusa, babi hutan, burung, } \\
\text { kura-kura, ikan) penting bagi rumahtangga anda baik untuk pendapatan } \\
\text { uang maupun untuk pakai sendiri? }\end{array}$} & \\
\hline & 1 & Tidak penting & \\
\hline & 2 & Penting & \\
\hline & 3 & Sangat penting & \\
\hline \multicolumn{3}{|c|}{ Modul Struktur dan Pelayanan } & \\
\hline \multirow[t]{4}{*}{ Var 41} & \multicolumn{2}{|r|}{ Seberapa sulit untuk pergi ke SMP terdekat? } & \\
\hline & 1 & Sangat sulit, tidak bisa & \\
\hline & 2 & Sulit tapi biasanya bisa & \\
\hline & 3 & Mudah saja & \\
\hline \multirow[t]{4}{*}{ Var 42} & \multicolumn{2}{|r|}{$\begin{array}{l}\text { Bagaimana kegiatan belajar di sekolah dimana anak-anak kampung ini } \\
\text { biasanya pergi? }\end{array}$} & \\
\hline & 1 & Buruk & \\
\hline & 2 & Sedang-sedang saja & \\
\hline & 3 & Baik & \\
\hline \multirow[t]{4}{*}{ Var 43} & \multicolumn{2}{|r|}{$\begin{array}{l}\text { Apakah ada anak-anak usia sekolah atau kuliah ( } 6 \mathrm{~s} / \mathrm{d} 24 \text { tahun) di } \\
\text { rumahtangga anda yang mendapatkan beasiswa (dari mana saja)? }\end{array}$} & \\
\hline & 1 & Tidak ada & \\
\hline & 3 & Ya, ada & \\
\hline & 3 & Tidak punya anak usia 6 s/d 24 tahun & \\
\hline \multirow[t]{4}{*}{ Var 44} & \multicolumn{2}{|r|}{$\begin{array}{l}\text { Seberapa sulit untuk pergi ke tempat pelayanan kesehatan terdekat (mis: } \\
\text { Pusban, Puskesmas, Polindes, Rumah Sakit, Bidan Kampung, dlI)? }\end{array}$} & \\
\hline & 1 & Sangat sulit, tidak bisa & \\
\hline & 2 & Sulit tapi biasanya bisa & \\
\hline & 3 & Mudah saja & \\
\hline
\end{tabular}




\begin{tabular}{|c|c|c|c|}
\hline & \multicolumn{2}{|r|}{ LINGKARI PILIHAN JAWABAN DI BAWAH INI! } & $\begin{array}{l}\text { ISI KOTAK INI DENGAN ANGKA SESUAI } \\
\text { DENGAN PILIHAN YANG DILINGKARI }\end{array}$ \\
\hline \multirow[t]{4}{*}{ Var 45} & \multicolumn{2}{|r|}{$\begin{array}{l}\text { Seberapa baik pelayanan kesehatan dimana masyarakat kampung ini biasanya } \\
\text { berobat? }\end{array}$} & \\
\hline & 1 & Buruk & \\
\hline & 2 & Sedang-sedang saja & \\
\hline & 3 & Baik & \\
\hline \multirow[t]{3}{*}{ Var 46} & \multicolumn{2}{|r|}{ Apakah anda memiliki kartu ASKES GAKIN atau ASKES KIN? } & \\
\hline & 1 & Tidak & \\
\hline & 3 & Ya & \\
\hline \multirow[t]{3}{*}{ Var 47} & \multicolumn{2}{|r|}{ Apakah anda memiliki Kartu Kompensasi BBM (KKB)? } & \\
\hline & 1 & Tidak & \\
\hline & 3 & Ya & \\
\hline \multirow[t]{4}{*}{ Var 48} & \multicolumn{2}{|r|}{$\begin{array}{l}\text { Dalam } 12 \text { bulan terakhir, seberapa sering rumahtangga anda menggunakan } \\
\text { BERAS RASKIN (bukan bantuan beras dari perusahaan atau LSM)? }\end{array}$} & \\
\hline & 1 & Sering beli & \\
\hline & 2 & Kadang-kadang beli & \\
\hline & 3 & Tidak pernah beli & \\
\hline \multirow[t]{5}{*}{ Var 49} & \multicolumn{2}{|r|}{ Seberapa sulit mendapatkan kredit usaha (pinjaman) dari DPM, CU atau bank? } & \\
\hline & 1 & Tidak bisa dapat, sulit sekali & \\
\hline & 2 & Sulit tapi bisa & \\
\hline & 3 & Bisa dan mudah saja & \\
\hline & 4 & Tidak pernah coba mengajukan karena tidak berminat & \\
\hline \multirow[t]{3}{*}{ Var 50} & \multicolumn{2}{|r|}{$\begin{array}{l}\text { Apakah selama } 12 \text { bulan terakhir ini, pernah diadakan pelatihan, penyuluhan, } \\
\text { kursus atau pendampingan usaha di kampung Anda? }\end{array}$} & \\
\hline & 1 & Tidak pernah & \\
\hline & 3 & Ya, pernah & \\
\hline \multirow[t]{4}{*}{ Var 51} & \multicolumn{2}{|r|}{ Bagaimana kondisi jalan dan jembatan sampai ke ibukota kecamatan? } & \\
\hline & 1 & Tidak ada & \\
\hline & 2 & Ada, dalam kondisi buruk & \\
\hline & 3 & Ada, dalam kondisi baik & \\
\hline
\end{tabular}




\begin{tabular}{|c|c|c|c|}
\hline & \multicolumn{2}{|r|}{ LINGKARI PILIHAN JAWABAN DI BAWAH INI! } & $\begin{array}{l}\text { ISI KOTAK INI DENGAN ANGKA SESUAI } \\
\text { DENGAN PILIHAN YANG DILINGKARI }\end{array}$ \\
\hline \multirow[t]{4}{*}{ Var 52} & \multicolumn{2}{|r|}{ Seberapa sulit untuk pergi ke pasar terdekat? } & \\
\hline & 1 & Sangat sulit, tidak bisa & \\
\hline & 2 & Sulit, tapi biasanya bisa & \\
\hline & 3 & Mudah saja & \\
\hline \multirow[t]{3}{*}{ Var 53} & \multicolumn{2}{|r|}{$\begin{array}{l}\text { Apakah selama } 12 \text { bulan terakhir ini anda mendapatkan bantuan rumah tidak } \\
\text { layak huni? }\end{array}$} & \\
\hline & 1 & Tidak & \\
\hline & 3 & Ya & \\
\hline \multirow[t]{4}{*}{ Var 54} & \multicolumn{2}{|r|}{$\begin{array}{l}\text { Bagaimana program dukungan PEMERINTAH di kampung anda dalam } 12 \\
\text { bulan terakhir (secara mutu dan jumlah)? }\end{array}$} & \\
\hline & 1 & Rendah & \\
\hline & 2 & Sedang-sedang saja & \\
\hline & 3 & Baik & \\
\hline \multirow[t]{4}{*}{ Var 55} & \multicolumn{2}{|r|}{$\begin{array}{l}\text { Bagaimana program dukungan Pihak Selain Pemerintah (perusahaan, } \\
\text { lembaga, dll) di kampung anda dalam } 12 \text { bulan terakhir (secara mutu dan } \\
\text { jumlah)? }\end{array}$} & \\
\hline & 1 & Rendah & \\
\hline & 2 & Sedang-sedang saja & \\
\hline & 3 & Baik & \\
\hline \multirow[t]{4}{*}{ Var 56} & \multicolumn{2}{|r|}{$\begin{array}{l}\text { Apakah anda bisa mendapatkan fasilitas komunikasi lewat telephone, } \\
\text { handphone atau radio (HT, SSB)? }\end{array}$} & \\
\hline & 1 & Sangat sulit, tidak bisa & \\
\hline & 2 & Sulit, tapi biasanya bisa & \\
\hline & 3 & Mudah saja & \\
\hline \multirow[t]{3}{*}{ Var 57} & \multicolumn{2}{|r|}{$\begin{array}{l}\text { Apakah Anda bisa mendapatkan pelayanan rohani yang sesuai dengan } \\
\text { kepercayaan atau agama Anda? }\end{array}$} & \\
\hline & 1 & Tidak bisa & \\
\hline & 3 & Ya, bisa & \\
\hline
\end{tabular}




\begin{tabular}{|c|c|c|c|}
\hline & \multicolumn{2}{|r|}{ LINGKARI PILIHAN JAWABAN DI BAWAH INI! } & $\begin{array}{l}\text { ISI KOTAK INI DENGAN ANGKA SESUAI } \\
\text { DENGAN PILIHAN YANG DILINGKARI }\end{array}$ \\
\hline \multirow[t]{3}{*}{ Var 58} & \multicolumn{2}{|r|}{$\begin{array}{l}\text { Apakah di kampung ini ada tempat rekreasi seperti tempat olah raga atau } \\
\text { obyek wisata atau tempat-tempat yang dianggap sebagai obyek wisata? }\end{array}$} & \\
\hline & 1 & Tidak ada & \\
\hline & 3 & Ya, ada & \\
\hline \multirow[t]{4}{*}{ Var 59} & \multicolumn{2}{|r|}{ Apakah anda pernah mendengar tentang GSM? } & \\
\hline & 1 & Tidak pernah mendengar & \\
\hline & 2 & Pernah dengar, tapi kurang faham & \\
\hline & 3 & Tahu tentang GSM dan faham tujuannya & \\
\hline
\end{tabular}




\section{Lampiran 2. Pengelompokan Indikator dan Klasifikasi Nilai}

\section{Kesejahteraan Subjektif}

\begin{tabular}{|l|c|c|c|}
\hline \multicolumn{1}{|c|}{ Indikator } & Nilai & Min & Maks \\
\hline Perasaan sejahtera (Var 11) & $1,2,3$ & 1 & 3 \\
\hline Perasaan miskin (Var 21) & $1,2,3$ & 1 & 3 \\
\hline Perasaan bahagia (Var 36) & $1,2,3$ & 1 & 3 \\
\hline Total & & 3 & 9 \\
\hline
\end{tabular}

Batas nilai

$\begin{array}{ll}\text { Miskin: } & 0-33.33 \\ \text { Sedang: } & 33,34-66,66 \\ \text { Sejahtera: } & 66,67-100\end{array}$

\section{Kesehatan}

\begin{tabular}{|l|l|c|c|}
\hline \multicolumn{1}{|c|}{ Indikator } & \multicolumn{1}{c|}{ Nilai } & Min & Maks \\
\hline Kekurangan makanan (Var 12) & 1,3 & 1 & 3 \\
\hline $\begin{array}{l}\text { Akses kepada air minum bersih } \\
\text { (Var 13) }\end{array}$ & $1,2,3$ & 1 & 3 \\
\hline $\begin{array}{l}\text { Akses kepada pelayanan } \\
\text { kesehatan (Var 14) }\end{array}$ & $1,2,3$ & 1 & 3 \\
\hline Total & & 3 & 9 \\
\hline
\end{tabular}

Batas nilai

$\begin{array}{ll}\text { Miskin: } & 0-38,89 \\ \text { Sedang: } & 38,90-61,10 \\ \text { Sejahtera: } & 61,11-100\end{array}$

\section{Kekayaan Materi}

\begin{tabular}{|l|l|c|c|}
\hline \multicolumn{1}{|c|}{ Indikator } & \multicolumn{1}{c|}{ Nilai } & Min & Maks \\
\hline Kondisi rumah (Var 15) & $1,2,3$ & 1 & 3 \\
\hline $\begin{array}{l}\text { Memiliki sepeda motor atau mesin } \\
\text { ces/mesin spid (Var 16) }\end{array}$ & 1,3 & 1 & 3 \\
\hline $\begin{array}{l}\text { Memiliki antena parabola atau } \\
\text { kulkas (Var 17) }\end{array}$ & 1,3 & 1 & 3 \\
\hline Total & & 3 & 9 \\
\hline
\end{tabular}

\section{Batas nilai}

$\begin{array}{ll}\text { Miskin: } & 0-44,44 \\ \text { Sedang: } & 44,45-55,55 \\ \text { Sejahtera: } & 55,56-100\end{array}$

\section{Pengetahuan}

\begin{tabular}{|l|c|c|c|}
\hline \multicolumn{1}{|c|}{ Indikator } & Nilai & Min & Maks \\
\hline Tingkat pendidikan formal (Var 18) & $1,2,3$ & 1 & 3 \\
\hline $\begin{array}{l}\text { Jumlah anak yang bersekolah atau } \\
\text { putus sekolah (Var 19) }\end{array}$ & $1,2,3$ & 1 & 3 \\
\hline Pengetahuan informal (Var 20) & $1,2,3$ & 1 & 3 \\
\hline Total & & 3 & 9 \\
\hline
\end{tabular}

\section{Batas nilai}

$\begin{array}{ll}\text { Miskin: } & 0-33,33 \\ \text { Sedang: } & 33,34-66,66 \\ \text { Sejahtera: } & 66,67-100\end{array}$




\section{Lingkungan Alam}

\begin{tabular}{|l|l|c|c|}
\hline \multicolumn{1}{|c|}{ Indikator } & \multicolumn{1}{c|}{ Nilai } & Min & Maks \\
\hline $\begin{array}{l}\text { Tingkat kerusakan lingkungan alam } \\
\text { (Var 23a) }\end{array}$ & $1,2,3$ & 1 & 3 \\
\hline $\begin{array}{l}\text { Keberadaan Burung Enggang atau } \\
\text { Bangau Tongtong (Var 24) }\end{array}$ & 1,3 & 1 & 3 \\
\hline $\begin{array}{l}\text { Pengambilan sumber daya alam } \\
\text { secara berlebihan (Var 25) }\end{array}$ & 1,3 & 1 & 3 \\
\hline Mutu air (Var 26) & $1,2,3$ & 1 & 3 \\
\hline Total & & 4 & 12 \\
\hline
\end{tabular}

Batas nilai

$\begin{array}{ll}\text { Miskin: } & 0-41,66 \\ \text { Sedang: } & 41,67-58,33 \\ \text { Sejahtera: } & 58,34-100\end{array}$

\section{Lingkungan Ekonomi}

\begin{tabular}{|l|l|c|c|}
\hline \multicolumn{1}{|c|}{ Indikator } & \multicolumn{1}{c|}{ Nilai } & Min & Maks \\
\hline Sumber penghasilan (Var 28a) & 1,3 & 1 & 3 \\
\hline Stabilitas penghasilan (Var 28b) & 1,3 & 1 & 3 \\
\hline $\begin{array}{l}\text { Persediaan beras dan kemampuan } \\
\text { membeli beras (Var 29) }\end{array}$ & $1,2,3$ & 1 & 3 \\
\hline Akses pada kredit (Var 49) & $1,2,3$ & 1 & 3 \\
\hline Total & & 4 & 12 \\
\hline
\end{tabular}

Batas nilai

$\begin{array}{ll}\text { Miskin: } & 0-41.67 \\ \text { Sedang: } & 41.68-58.32 \\ \text { Sejahtera: } & 58.33-100\end{array}$

\section{Lingkungan Sosial}

\begin{tabular}{|l|l|c|c|}
\hline \multicolumn{1}{|c|}{ Indikator } & \multicolumn{1}{c|}{ Nilai } & Min & Maks \\
\hline Tingkat tolong-menolong (Var 30) & $1,2,3$ & 1 & 3 \\
\hline Tingkat rasa saling percaya (Var 31) & $1,2,3$ & 1 & 3 \\
\hline Frekuensi konflik (Var 32) & 1,3 & 1 & 3 \\
\hline Total & & 3 & 9 \\
\hline
\end{tabular}

Batas nilai

$\begin{array}{ll}\text { Miskin: } & 0-38,89 \\ \text { Sedang: } & 38,90-61,10 \\ \text { Sejahtera: } & 61,11-100\end{array}$

\section{Lingkungan Politik}

\begin{tabular}{|l|c|c|c|}
\hline \multicolumn{1}{|c|}{ Indikator } & Nilai & Min & Maks \\
\hline $\begin{array}{l}\text { Akses kepada sumber daya alam } \\
\text { (Var 33) }\end{array}$ & $1,2,3$ & 1 & 3 \\
\hline Akses kepada informasi (Var 34) & $1,2,3$ & 1 & 3 \\
\hline $\begin{array}{l}\text { Keikutsertaan dalam pengambilan } \\
\text { keputusan (Var 35) }\end{array}$ & $1,2,3$ & 1 & 3 \\
\hline Total & & 3 & 9 \\
\hline
\end{tabular}

Batas nilai

$\begin{array}{ll}\text { Miskin: } & 0-33,33 \\ \text { Sedang: } & 33,34-66,66 \\ \text { Sejahtera: } & 66,67-100\end{array}$




\section{Lingkungan Infrastruktur dan Layanan}

\begin{tabular}{|l|c|c|c|}
\hline \multicolumn{1}{|c|}{ Indikator } & Nilai & Min & Maks \\
\hline Fasilitas pendidikan dasar (Var 41) & $1,2,3$ & 1 & 3 \\
\hline Kualitas pendidikan di sekolah (Var 42) & $1,2,3$ & 1 & 3 \\
\hline Fasilitas pelayanan kesehatan (Var 44) & $1,2,3$ & 1 & 3 \\
\hline Kualitas pelayanan kesehatan (Var 45) & $1,2,3$ & 1 & 3 \\
\hline $\begin{array}{l}\text { Pelatihan dan pendampingan usaha } \\
\text { (Var 50) }\end{array}$ & 1,3 & 1 & 3 \\
\hline Kondisi jalan dan jembatan (Var 51) & $1,2,3$ & 1 & 3 \\
\hline Fasilitas pasar (Var 52) & $1,2,3$ & 1 & 3 \\
\hline Fasilitas komunikasi (Var 56) & $1,2,3$ & 1 & 3 \\
\hline Total & & 8 & 24 \\
\hline
\end{tabular}

Batas nilai

$\begin{array}{ll}\text { Miskin: } & 0-35,42 \\ \text { Sedang: } & 35,43-64,57 \\ \text { Sejahtera: } & 64,58-100\end{array}$

\section{Indeks Inti (Kebutuhan Dasar)}

\begin{tabular}{|l|c|}
\hline \multicolumn{1}{|c|}{ Indeks dasar } & Batas nilai untuk miskin \\
\hline Health & 38,89 \\
\hline Wealth & 44,44 \\
\hline Knowledge & 33,33 \\
\hline
\end{tabular}

Batas nilai

$\begin{array}{ll}\text { Miskin: } & 0-38,89 \\ \text { Sedang: } & 38,90-61,10 \\ \text { Sejahtera: } & 61,11-100\end{array}$

\section{Indeks Konteks (Lingkungan Pendukung)}

\begin{tabular}{|l|c|}
\hline \multicolumn{1}{|c|}{ Indeks dasar } & Batas nilai untuk miskin \\
\hline Alam & 41,67 \\
\hline Ekonomi & 41,67 \\
\hline Sosial & 38,89 \\
\hline Politik & 33,33 \\
\hline Infrastruktur \& Layanan & 35,42 \\
\hline
\end{tabular}

\section{Batas nilai}

$\begin{array}{ll}\text { Miskin: } & 0-38,19 \\ \text { Sedang: } & 38,20-61,80 \\ \text { Sejahtera: } & 61,81-100\end{array}$

\section{Indeks Kemiskinan Agregat}

Yaitu rata-rata penjumlahan Indeks Inti dan Indeks Konteks

Batas nilai

$\begin{array}{ll}\text { Miskin: } & 0-38,54 \\ \text { Sedang: } & 38,55-61,45 \\ \text { Sejahtera: } & 61,46-100\end{array}$




\section{Lampiran 3. Kode Desa dan Kecamatan}

\section{Desa}

$\begin{array}{lr}\text { Pisang } & 22004 \\ \text { Salak } & 22010 \\ \text { Melon } & 32007 \\ \text { Jambu } & 52003 \\ \text { Nenas } & 72004 \\ \text { Lai } & 72007 \\ \text { Durian } & 72009 \\ \text { Mangga } & 72010 \\ \text { Jeruk } & 72019 \\ \text { Semangka } & 72020 \\ \text { Anggur } & 112001 \\ \text { Sirsak } & 112007 \\ \text { Apel } & 182002\end{array}$

\section{Kecamatan}

$\begin{array}{lr}\text { Makaranga } & 2 \\ \text { Bangkirai } & 3 \\ \text { Meranti } & 5 \\ \text { Jati } & 7 \\ \text { Agatis } & 11 \\ \text { Ulin } & 18\end{array}$




\section{Mengkaji Kemiskinan dan Kesejahteraan Rumah Tangga Sebuah Panduan dengan Contoh dari Kutai Barat, Indonesia}

Panduan ini dirancang sebagai petunjuk bagi para pemantau kemiskinan di tingkat desa, kecamatan dan kabupaten dalam memantau kesejahteraan rumah tangga. Sistem pemantauan yang dijelaskan di sini dibuat sesuai dengan kondisi spesifik di Kabupaten Kutai Barat, Kalimantan Timur, dan merupakan contoh bagaimana melakukan kegiatan serupa di tempat lain. Panduan ini terdiri dari 11 modul yang menguraikan secara rinci bagaimana mengembangkan indikator kemiskinan lokal, bagaimana mempersiapkan dan melaksanakan survei pemantauan kemiskinan, bagaimana menganalisis data pemantauan, dan bagaimana memanfaatkan hasil temuan dengan sebaik-baiknya.

Pendekatan dikembangkan bersama oleh Tim Pemantauan Kemiskinan dari Pemerintah Kabupaten Kutai Barat dan Proyek Kemiskinan dan Desentralisasi CIFOR-BMZ mengenai "Menjadikan pemerintah daerah lebih tanggap terhadap kemiskinan: Pengembangan indikator dan alat untuk mendukung pengembangan penghidupan yang berkelanjutan dalam desentralisasi".

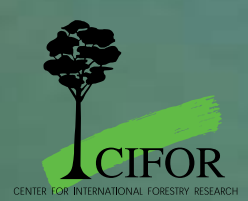

